Philosophica 4

\title{
Le varietà \\ del naturalismo
}

IncontriCa'Foscari-Paris 1

a cura di

Gaia Bagnati, Melania Cassan e Alice Morelli

\section{Edizioni}

Ca'Foscari 

Le varietà del naturalismo

\section{Philosophica}

Serie diretta da

Luigi Perissinotto

Cecilia Rofena

4

Edizioni

Ca'Foscari 


\section{Philosophica}

\section{Direttori}

Luigi Perissinotto (Università Ca' Foscari Venezia, Italia)

Cecilia Rofena (Università Ca' Foscari Venezia, Italia)

\section{Comitato scientifico}

Silvana Borutti (Università degli studi di Pavia, Italia)

Jean-Pierre Cometti (Université de Provence - Aix-Marseille I, France)

Arnold Davidson (University of Chicago, USA)

Roberta Dreon (Università Ca' Foscari Venezia, Italia)

Giuseppe Goisis (Università Ca' Foscari Venezia, Italia)

Daniele Goldoni (Università Ca' Foscari Venezia, Italia)

Mauro Nobile (Università degli Studi di Milano-Bicocca, Italia)

Gian Luigi Paltrinieri (Università Ca' Foscari Venezia, Italia)

Vicente Sanfélix Vidarte (Universitat de València-Estudi General, España)

\section{Direzione e redazione}

Università Ca' Foscari Venezia

Dipartimento di Filosofia e Beni Culturali

Palazzo Malcanton Marcorà

Dorsoduro 3484/D, 30123 Venezia

e-ISSN 2610-8925

ISSN 2610-8933

URL https://edizionicafoscari.unive.it/it/edizioni/collane/philosophica/ 


\section{Le varietà del naturalismo Incontri Ca' Foscari-Paris 1}

a cura di

Gaia Bagnati, Melania Cassan

e Alice Morelli

Venezia

Edizioni Ca' Foscari - Digital Publishing 2019 
Le varietà del naturalismo. Incontri Ca' Foscari-Paris 1

Gaia Bagnati, Melania Cassan, Alice Morelli (a cura di)

(c) 2019 Gaia Bagnati, Melania Cassan, Alice Morelli per il testo

(C) 2019 Edizioni Ca' Foscari - Digital Publishing per la presente edizione

\section{(c) (i)}

Quest'opera è distribuita con Licenza Creative Commons Attribuzione 4.0 Internazionale This work is licensed under a Creative Commons Attribution 4.0 International License

Qualunque parte di questa pubblicazione può essere riprodotta, memorizzata in un sistema di recupero dati o trasmessa in qualsiasi forma o con qualsiasi mezzo, elettronico o meccanico, senza autorizzazione, a condizione che se ne citi la fonte.

Any part of this publication may be reproduced, stored in a retrieval system, or transmitted in any form or by any means without permission provided that the source is fully credited.

Edizioni Ca' Foscari - Digital Publishing

Università Ca' Foscari Venezia,

Dorsoduro 3246, 30123 Venezia

http://edizionicafoscari.unive.it|ecf@unive.it

1a edizione luglio 2019

ISBN 978-88-6969-325-0 [ebook]

ISBN 978-88-6969-326-7 [print]

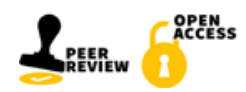

Certificazione scientifica delle Opere pubblicate da Edizioni Ca' Foscari - Digital Publishing: tutti i saggi pubblicati hanno ottenuto il parere favorevole da parte di valutatori esperti della materia, attraverso un processo di revisione anonima sotto la responsabilità del Comitato scientifico della collana. La valutazione è stata condotta in aderenza ai criteri scientifici ed editoriali di Edizioni Ca' Foscari.

Scientific certification of the works published by Edizioni Ca' Foscari - Digital Publishing: all essays published in this volume have received a favourable opinion by subjectmatter experts, through an anonymous peer review process under the responsibility of the Scientific Committee of the series. The evaluations were conducted in adherence to the scientific and editorial criteria established by Edizioni Ca' Foscari.

Il presente volume è stato pubblicato con il contributo dei fondi MIUR - Bando PRIN 2015, progetto «ll problema dell'indeterminatezza. Significato, conoscenza, azione».

Le varietà del naturalismo. Incontri Ca' Foscari-Paris 1 / Gaia Bagnati, Melania Cassan, Alice Morelli (a cura di) - 1. ed. - Venezia: Edizioni Ca' Foscari - Digital Publishing, 2019. - 180 p.; 23 cm. - (Philosophica; 4). - ISBN 978-88-6969-326-7.

URL https://edizionicafoscari.unive.it/libri/978-88-6969-325-0/

DOI http://doi.org/10.30687/978-88-6969-325-0 
Le varietà del naturalismo

Incontri Ca' Foscari-Paris 1

a cura di Gaia Bagnati, Melania Cassan e Alice Morelli

\section{Sommario}

Le 'varietà' del naturalismo

Introduzione

Emanuela Scribano

II naturalismo oggi

Abbozzo di una mappa e alcune riflessioni

Luigi Perissinotto

La natura e gli stati abituali nell'Etica Nicomachea Analogie e differenze

Flavia Farina

Fear as a Destructive Pain

Human Nature and Violent Affections in the Eudemian Ethics of Aristotle

Gaia Bagnati

Naturalismo e cosmopolitismo nell'Antichità

Epicureismo vs stoicismo

Pierre-Marie Morel

Riflessioni sul concetto di natura in Lucio Anneo Seneca Melania Cassan

Onnipotenza divina e ordine naturale nel Medioevo

L'immutabilità del passato come garanzia del rispetto del corso della Natura

Andrea Possamai

Descartes aux limites du naturalisme

"La force qu'a l'âme de mouvoir le corps " 
La Natura e il Metodo

La conoscenza come lotta per la libertà in Spinoza

Luigi Emilio Pischedda

Naturalisme et scepticisme

Le problème de l'identité personnelle chez David Hume Iris Douzant

Nel tempo e nello spazio. Linguaggio e natura nella filosofia di Ludwig Wittgenstein

Alice Morelli

II naturalismo culturale di Dewey

Il caso della mente

Roberta Dreon

Il linguaggio come collante tra menti individuali e socialità umana

Filippo Batisti 


\section{Le 'varietà' del naturalismo Introduzione}

Emanuela Scribano

Università Ca' Foscari Venezia, Italia

'Naturalismo' è concetto parassitario da 'natura'. Inteso come opzione filosofica il naturalismo dipende quindi dalla definizione di 'natura', da ciò cui si pensa che la natura si opponga e di quelli che si credono gli strumenti adeguati per conoscerla. Il 'naturalismo' prevede inoltre una possibile attività, quella della 'naturalizzazione' di fenomeni o campi del sapere sui quali la riconduzione alla natura o l'applicazione delle metodologie utilizzate per studiare la natura siano state precedentemente escluse o messe in discussione. In questo senso il naturalismo include una tensione ad applicarsi e conquistare campi del sapere, ed è quindi categoria mobile e dinamica.

La storia del pensiero occidentale può essere letta anche in termini di naturalismo e naturalizzazione, e quindi dei concetti cui il naturalismo si oppone e di cui la naturalizzazione aspira ad appropriarsi, una lettura tanto più attraente quanto più spesso il conflitto tra la natura e ciò che le viene opposto ha prodotto risultati incerti, dove gli stessi eventi potevano essere letti con altrettanta legittimità come una naturalizzazione di ciò che si oppone a natura o come un assorbimento della natura nel suo opposto. Ricorderò solo il caso paradigmatico della opposizione della natura all'arte.

La prima grande impresa filosofica di naturalizzazione è stata certamente quella messa a punto da Aristotele contro Platone, contestando l'assorbimento della natura nell'arte, sotto forma del progetto divino, elaborato nel Timeo e nel Politico. È noto quanto la scelta antiplatonica di Aristotele sia stata contrastata, travisata e infine tradita in tanta filosofia di ispirazione cristiana che pure intendeva richiamarsi ad Aristotele, e che ritornava, invece, all'assorbimento della natura nell'arte, attraverso la tesi secondo la quale la natura sarebbe l'opera del progetto intelligente di una mente divina, come 
Platone aveva voluto. Spetterà alla scienza moderna, con la messa al bando dell'uso delle cause finali e quindi dell'appello al progetto divino per spiegare l'ordine del mondo, rinnovare la via aristotelica di netta separazione della natura dall'arte, anche a costo di naturalizzare Dio. È quanto aveva osato fare Cartesio, quando aveva fondato le leggi di natura sugli attributi divini e proposto quelle stesse leggi come antidoto al progetto divino per spiegare l'origine del mondo. Questo progetto è stato contrastato all'interno della stessa scienza moderna, col massiccio richiamo al finalismo e al disegno divino da parte di Newton. A Newton scienziato e filosofo sarebbe però legittimo chiedere se il suo progetto, invece di un ritorno all'assorbimento della natura nell'arte divina di platonica memoria, non vada piuttosto letto come una proposta metafisica nella quale Dio è stato ancora una volta naturalizzato, dal momento che la mente calcolatrice divina è risultata indispensabile alla fondazione delle leggi di natura. Col che Cartesio e Newton avrebbero trovato un punto di convergenza profondo.

Se i confini del naturalismo e della naturalizzazione si misurano sulla possibilità di utilizzare un metodo scientifico, ci si dovrà misurare con posizioni come quella di Hobbes, e con la sua tesi secondo la quale scienza perfetta è possibile solo se applicata a oggetti frutto dell'artificio umano: la politica, il linguaggio. Siamo di fronte ad una naturalizzazione della politica o ad una emarginazione della natura dalla scienza? Ed è possibile una scienza completamente priva di implicazioni metafisiche? In ogni caso, se ci affidiamo alla scienza per decidere cosa si debba intendere per natura, la discussione si aprirà su quale sia la scienza di cui si parla e quali i metodi scientifici legittimati a decidere dell'identità della natura.

Per la natura poi, un'altra opposizione può innescare una narrazione altrettanto appassionante, quella tra natura e sovra-natura. La natura di Fernel con le sue cause occulte, di Van Helmont con il suo archaeus, di Glisson con la sua forza energetica, di Cudworth con la sua natura plastica si è trovata piena di spiriti, di forze immateriali, strumenti del divino, indispensabili ad assicurarne la coesione. Nel vitalismo della prima modernità la natura è stata divinizzata o il divino è stato naturalizzato?

Per la natura umana, le vicende della sua 'naturalizzazione' non sono state meno complesse. Alla lunga ricerca su cosa debba intendersi per natura umana, ricercata allo stato puro nella solitudine dei ragazzi abbandonati nei boschi o nei selvaggi, si è opposta l'impossibilità di separare la natura e l'arte nell'uomo. L'uomo separato dalle sue opere è un essere deforme, impossibilitato a essere animale ma non più uomo. Senza questa reazione ai miti moderni sulla natura umana al di fuori della società e della cultura non si capirebbe il programma di Hume di scrivere una storia 'naturale' della religione, della morale, delle istituzioni giuridiche, della politica, riassorbendo 
l'arte nella natura, rendendo questa inintelligibile senza i suoi prodotti e opponendosi ad ogni tentativo filosofico che speri di spiegare le istituzioni umane come frutto di progetto consapevole e artificio.

Se poi ci si volge alla opposizione della natura ad un'altra categoria con la quale lungamente si è confrontata, ossia quella di sovranatura, la storia di questo confronto non sarà meno appassionante. In questo caso, l'opera di naturalizzazione più impressionante, è forse quella compiuta da Tommaso nei confronti di Agostino. Si tratta di un'operazione che, per alcuni aspetti rilevanti, si sovrappone alla precedente, perché, con quella, si costruisce come scelta per Aristotele contro Platone. La naturalizzazione della mente e della conoscenza umane operata da Tommaso separandole da quel contatto con il divino che Agostino aveva giudicato imprescindibile, è anzi all'origine della opposizione della natura alla sovra-natura. Non senza sorpresa, chi ama sorprendersi nel ricostruire le complesse vie della riflessione filosofica, dovrà constatare che lo stesso filosofo - Tommaso d'Aquino - che imponeva il ritorno all'assorbimento della natura nell'arte divina, si adoperava per liberare il funzionamento della mente umana dalla presenza del divino.

La raccolta di saggi che segue è frutto di due giornate di studio dedicate proprio a indagare e mettere a punto gli incerti confini, le mutevoli sembianze e le metamorfosi del naturalismo, come il titolo volutamente suggestivo scelto dalle curatrici attesta.

La difficoltà di porre confini rigidi tra natura e cultura è rivendicata come metodo fecondo nel Dewey discusso da Roberta Dreon, tanto da non temere l'ossimoro di un 'naturalismo culturale', mentre Filippo Batisti, in sintonia con l'indagine precedente, si concentra sul vincolo sociale che il linguaggio assicura, sempre nel pensiero di Dewey. Al ripensamento dei confini tra natura e cultura non è estraneo nemmeno l'Aristotele studiato da Flavia Farina con la teoria della virtù come abitudine stabile, e quindi quasi come pascaliana 'seconda natura'. Un autore come Hume, che ha individuato nella natura umana la fortezza alla quale dare l'assalto per comprendere una volta per tutte la struttura di tutte le conoscenze e le acquisizioni umane, deve confessare i limiti del suo riduzionismo nel testo di Iris Douzant. Luigi Pischedda mostra un filosofo come Spinoza, la cui riduzione del divino alla natura è paradigmatica, interrogarsi sulla possibilità di aprire i confini del naturalismo al di là del metodo scientifico, in questo modo ponendosi in ideale dialogo con il Wittgenstein indagato da Alice Morelli, per il quale si individua una possibile apertura ad un naturalismo che non si identifichi con il metodo scientifico. L'appello alla natura umana come criterio per classificare le passioni in Aristotele è al centro dello studio di Gaia Bagnati. Il valore assiologico della parola 'natura' e i molti modi nei quali può essere declinata sono al centro dell'interesse di Melania Cassan nel suo saggio 
su Seneca. La pressione contro i vincoli imposti dal naturalismo sono al centro della ricostruzione delle discussioni tardo antiche e medievali sulla possibilità di modificare il passato studiate da Andrea Possamai. Pierre-Marie Morel mostra le aperture al naturalismo attraverso il cosmopolitismo percorse all'interno degli stessi seguaci dell'epicureismo. Denis Kambouchner fornisce una lettura originale del potere dell'anima sul corpo rivendicato da Descartes, in realtà sorprendentemente sbilanciato verso i poteri del corpo. Infine, Luigi Perissinotto traccia una mappa delle versioni del naturalismo e dei progetti di naturalizzazione presenti nell'attuale dibattito filosofico, proponendo una forma di naturalismo che non debba necessariamente impegnarsi in un qualche programma di naturalizzazione.

Si tratta di letture e approcci alla problematica del naturalismo variegati sia relativamente alle tematiche sia relativamente agli autori implicati, che del naturalismo dimostrano l'attraente vitalità.

Mi fa piacere aggiungere che questi contributi hanno visto interagire dottorandi e docenti di due diverse Università, Paris I PathéonSorbonne e Ca' Foscari Venezia, unite in uno stesso percorso dottorale. Quelli che vengono presentati qui non sono quindi solo i risultati di un convegno teso a promuovere un'occasione di incontro scientifico, ma anche il risultato di un lavoro filosofico comune, e, negli auspici di chi scrive, di lunga durata. 


\title{
Il naturalismo oggi Abbozzo di una mappa e alcune riflessioni
}

\section{Luigi Perissinotto}

Università Ca’ Foscari Venezia, Italia

\begin{abstract}
This paper tries to draw a map of the various versions of naturalism to which the current philosophical debate aims - from the most radical, or 'hard' ones, to the mildest, or liberal ones - and of the different projects of naturalization that are associated to them. In particular, in the first paragraphs, the present article will consider Timothy Williamson's and Penelope Maddy's attempts to inherit the demands of naturalism without declaring to be a naturalist (Williamson), or without making naturalism an empty slogan or a kind of masked first philosophy (Maddy). In the second part, the connections between epistemological naturalism and ontological or metaphysical naturalism will be analysed. The questions will be: (1) is it possible to be naturalist with regard to epistemology without being naturalist with regard to ontology?; (2) is it possible to be ontologically naturalist without being epistemologically naturalist?
\end{abstract}

Keywords Naturalism. Ontological naturalism. Epistemological naturalism. Metaphilosophy. Second philosophy.

Sommario 1 Che cos'è il naturalismo? - 2 Williamson: spirito scientifico versus naturalismo. - 3 Maddy: un naturalismo austero. - 4 Il naturalismo tra epistemologia e ontologia. - 5 Naturalismo 'duro' e naturalismo 'soffice'. 


\section{$1 \quad$ Che cos'è il naturalismo?}

Molti filosofi contemporanei, in particolare molti tra i filosofi che appartengono alla cosiddetta 'filosofia analitica', 1 ma anche diversi tra quelli che si richiamano al pragmatismo, soprattutto al pragmatismo di William James e John Dewey, sembrano convinti non solo che 'naturalismo' sia il modo più efficace e adeguato di caratterizzare gli obiettivi, lo stile e l'orientamento del loro impegno filosofico, ma soprattutto che il naturalismo non abbia oggi, nell'età «della scienza e della tecnica orientata scientificamente» (Weber 1919; trad. it. 19), alternative filosoficamente serie. Ovviamente, non mancano tra i filosofi, per esempio tra quelli che si richiamano alla fenomenologia o al pensiero ermeneutico, ma anche tra coloro che vogliono restare fedeli all'impostazione originaria della filosofia analitica ${ }^{2} \mathrm{o}$ a una versione del pragmatismo ispirata da Charles S. Peirce più che da James

1 Secondo Rea «[i]l naturalismo filosofico ha dominato il mondo accademico occidentale [invero, Rea si riferisce in maniera quasi esclusiva alla tradizione pragmatista e analitica americana] per quasi un secolo. Oggi non solo è di moda, ma gode l'altero statuto di ortodossia accademica» (2004, 1; trad. dell'Autore [d'ora in avanti, ove non specificato, le traduzioni sono di chi scrive]). Secondo $\operatorname{Kim}(2003,84)$, il naturalismo è stato l'ideologia filosofica e il credo dominante della filosofia analitica per gran parte del secolo scorso. In realtà, molti filosofi analitici del secolo scorso possono difficilmente essere classificati come 'naturalisti', almeno se si dà al termine un senso non eccessivamente vago o generico. Non erano naturalisti i padri fondatori della filosofia analitica (vedi nota successiva) né lo erano i cosiddetti 'filosofi del linguaggio ordinario' (Ryle, Austin, ecc.). Né è agevole classificare tra i naturalisti i positivisti logici, nonostante il loro appello alla scienza e a una visione scientifica del mondo, soprattutto se si ricorda che è principalmente in polemica con Carnap che Quine rivendicò il proprio naturalismo e si propose di naturalizzare l'epistemologia: «La mia è una posizione naturalistica: io vedo la filosofia non [al modo di Carnap] come propedeutica a priori o una base per la scienza, ma come continua con la scienza. [...] Non c'è nessun punto di osservazione esterno, nessuna filosofia prima» (Quine 1969; trad. it., 146). Sul naturalismo di Quine e sul senso della sua opposizione a Carnap e al positivismo logico si veda Stroud (2011, 245-6).

2 Vi è un consenso diffuso che tra i padri fondatori della filosofia analitica vadano annoverati George E. Moore, Bertrand Russell, Gottlob Frege e Ludwig Wittgenstein. Sicuramente Moore e Frege non solo non erano naturalisti (in nessuno dei diversi sensi che il termine 'naturalismo' ha oggi assunto), anzi erano, sempre considerando gli attuali sensi del termine, anti-naturalisti. Al riguardo basti ricordare la denuncia da parte di Moore (1903), nei suoi Principia Ethica, della cosiddetta 'fallacia naturalistica' o l'antipsicologismo e il 'platonismo' che caratterizzano l'impostazione di Frege. Più complessa è la situazione per quanto riguarda Russell; nel corso degli anni Venti, nel pensiero di Russell emerse, infatti, un impulso, diciamo così, 'naturalista' che è particolarmente evidente nel suo Analysis of Mind (Russell 1921). Ancora più complessa è la situazione per quanto riguarda Wittgenstein. Come vedremo, alcuni interpreti hanno parlato a proposito del cosiddetto 'secondo' Wittgenstein di 'naturalismo liberale'. Per quanto riguarda il 'primo' Wittgenstein bisogna riconoscere che quello che si legge all'inizio della proposizione 6.53 del Tractatus logico-philosophicus, ossia che «[i]l metodo corretto della filosofia sarebbe propriamente questo: Nulla dire se non ciò che può dirsi; dunque, proposizioni della scienza naturale - dunque, qualcosa che con la filosofia nulla ha a che fare» (Wittgenstein [1921-1922] 1989, 175), suona molto naturalista, anche se quasi sicuramente non è stato scritto in uno spirito naturalista. 
o Dewey, ${ }^{3}$ coloro che sono persuasi che il naturalismo sia, filosoficamente, un vicolo più o meno cieco e che ritengono, di conseguenza, che chi si dichiara naturalista rischi di star confessando, credendo di vantare un merito, una colpa.

È indubbio, però, che il naturalismo è ormai, e da parecchio tempo, un'opzione viva e ampiamente condivisa dentro e fuori la filosofia analitica. Ma che cosa comporta per un filosofo definirsi naturalista o rivendicare apertamente il proprio naturalismo? E che cosa esattamente rimproverano al naturalismo coloro che ritengono che la filosofia debba resistere a quello che, in un saggio ormai famoso, Stroud (2011, 223) ha chiamato «il fascino del naturalismo»? Insomma, che cosa significa (in un senso positivo) essere naturalisti e che cosa (in negativo) devono escludere o combattere ${ }^{4}$ coloro che vogliano proclamarsi 'naturalisti'? E che cosa significa 'naturale' per i naturalisti e che cosa sarebbe, sempre per costoro, il 'non-naturale' o il 'soprannaturale'?

\section{Williamson: spirito scientifico versus naturalismo}

Molti di coloro che hanno tentato di rispondere a queste domande si sono trovati, prima o poi, a riconoscere che il termine 'naturalismo' è usato nella filosofia contemporanea secondo tanti di quei sensi, o secondo un senso così vago o generico, che dire di un filosofo che è un naturalista (o, per quello che qui vale, anti-naturalista) rischia di essere ben poco informativo o discriminante. ${ }^{5}$ Non può allora stupi-

3 Il riferimento è a quello che Ramberg (2018, 313-14) ha chiamato 'pragmatismo filosofico'. Si tratta di un pragmatismo, il cui rappresentante più famoso è forse Robert Brandom, che «rende centrale la nozione di capacità di azione (agency) e di intervento, che assume che la pratica sia la fonte della normatività e che espande il più possibile l'ambito del ragionamento mezzi-fine». A questo pragmatismo filosofico si contrappone quello che sempre Ramberg chiama 'naturalismo pragmatico' il quale ha tra i suoi principali esponenti Huw Price, Philip Kitcher e Richard Rorty. Si tratta di un pragmatismo che riprende quella lezione di James e di Dewey che è così sintetizzata da Kitcher (2012, xiii): «Entrambi [James e Dewey] sono diffidenti nei confronti dell'idea di problemi filosofici perenni (timeless) che richiedono di essere affrontati da ogni generazione; entrambi assumono che le più profonde sfide filosofiche di un'epoca dipendano dalla precedente evoluzione della vita umana e della cultura».

4 «[L]a prima cosa che si deve fare con il naturalismo, così come con ogni dottrina filosofica o 'ismo', è domandarsi contro che cosa essa è» (Stroud 2011, 224).

5 Si potrebbe comunque sostenere che, sotto questo riguardo, il concetto di naturalismo non differisce dalla gran parte dei concetti filosofici, per esempio dai concetti di realismo, idealismo, ecc. Come scrive Laudisa $(2014,3)$, «[a]nalogamente a molti altri concetti filosofici, non esiste infatti una formulazione univoca e universalmente condivisa di naturalismo, ma piuttosto un ampio albero genealogico di concetti più o meno strettamente imparentati, che contribuiscono nel loro complesso a formare un clima filosofico più che una teoria univoca e strettamente strutturata». Da questo punto di vista il termine 'naturalismo' non è univoco, ma nemmeno ambiguo. Ne segue anche che la prima domanda da fare a chi si dichiara naturalista dovrebbe essere: 'Naturalista in che senso?'. 
re che alcuni filosofi che si potrebbero facilmente classificare come naturalisti ${ }^{6}$ preferiscano non fare ricorso a questa etichetta per caratterizzare il proprio impegno filosofico oppure che lo facciano con molta cautela e diverse distinzioni.

Un primo esempio di quanto appena osservato è Timothy Williamson. In un breve saggio che come titolo porta proprio la domanda «What is Naturalism?» Williamson, dopo aver osservato che la concezione della filosofia da lui difesa ${ }^{7}$ è stata trattata da alcuni commentatori "come una forma di naturalismo», cerca di spiegare perché, con un certo stupore di quegli stessi commentatori, egli «resista a essere descritto come un naturalista» (Williamson 2014a, 29). La sua spiegazione è che non è affatto chiaro che cosa si nasconda dietro «lo slogan naturalista» (Williamson 2014a, 29) e che il naturalismo rischia, di conseguenza, di essere solo un altro dei tanti dogmi in cui, per dirla con Wittgenstein (1953, § 131; trad. it., 71), «si cade così facilmente facendo filosofia». Certo, come i naturalisti proclamano e come lo stesso Williamson si impegna a sostenere, «[l]a filosofia dovrebbe essere fatta in uno spirito scientifico», ma proprio «[p]er questo non dovremmo filosofare invocando slogan sul naturalismo [...] o lasciandoci coinvolgere in qualcuna delle altre forme di pigrizia mentale (lazy-mindedness) che la parola 'naturalismo' è così tanto capace di incoraggiare» (Williamson 2014a, 31).

Più in particolare, almeno tre sono le critiche che Williamson rivolge al naturalismo. La prima è che il naturalismo tratta come autoevidente ciò che auto-evidente non è, ossia «che non ci possano essere cose che si possono scoprire solo mediante mezzi non-scientifici o che non possono essere affatto scoperte» (Williamson 2014a, 29). La seconda è che il naturalismo «è meno restrittivo di quanto si potrebbe pensare», tant'è vero che «alcuni dei suoi severi sostenitori si impegnano a postulare un'anima o un dio se il farlo si rivela esser parte della migliore spiegazione della nostra esperienza» (Williamson 2014a, 29). ${ }^{8}$ La terza critica consiste nell'osservare che i naturalisti

6 Per esempio, perché rifiutano ogni forma di 'soprannaturalismo' o perché ritengono che il metodo filosofico non si distingua (o non si debba distinguere) da quello della scienza o, quantomeno, non confligga (o non debba confliggere) con esso.

7 Williamson si sta qui riferendo alla concezione della filosofia da lui difesa in Williamson 2007. Secondo questa concezione, che egli caratterizza come «anti-eccezionalismo riguardo alla filosofia», la filosofia è «molto meno differente negli scopi e nei metodi da altre forme di ricerca intellettuale di quanto le immagini che essa dà di sé (its self-images) usualmente suggeriscano» (Williamson 2014a, 29).

8 Così considerata, la postulazione di un'anima o di un dio sarebbe «un'applicazione del metodo scientifico» (Williamson 2014a, 29). Ciò significa che quel naturalismo che è chiamato 'epistemologico' (o 'metodologico' o 'epistemico') non è, secondo Williamson (2014a, 29), «incompatibile in linea di principio con tutte le forme di religione», anche se, «[i]n pratica, la gran parte dei naturalisti dubitano che la credenza in anime 0 in dei resista all'indagine della scienza». 
si trovano di fronte a un dilemma: «[s]e sono troppo inclusivi riguardo a ciò che considerano scienza, il naturalismo perde il suo mordente. [...] Ma se sono troppo esclusivi riguardo a ciò che considerano scienza, il naturalismo perde la sua credibilità in quanto impone un metodo appropriato alla scienza naturale ad aree per le quali è inappropriato» (Williamson 2014a, 30).

Riguardo a queste critiche possiamo qui limitarci a tre brevi considerazioni. Per quanto riguarda la terza delle critiche si può osservare che tra i naturalismi contemporanei vi sono naturalismi sicuramente esclusivi, per i quali 'scienza' significa, in maniera esclusiva o nella sostanza, fisica e naturalismi molto più inclusivi per i quali scienze sono anche, per esempio, la storia o l'economia e che ritengono che abbia ben poco senso pensare che la fisica possa (almeno idealmente o nel futuro) fare meglio della storia quando si tratta di capire e spiegare la sconfitta di Napoleone a Waterloo o dell'economia quando si tratta di capire o di spiegare l'inflazione. ${ }^{9}$ Ovviamente, i naturalisti più inclusivi sono, dal punto di vista metodologico, propensi al pluralismo, mentre i naturalisti più esclusivi sembrano propendere decisamente per il monismo metodologico convinti come sono che, per quanto diverse siano tra di loro, tutte le varie scienze, se considerate «a un livello sufficientemente astratto», mostrino di impiegare «un singolo metodo generale» (Williamson 2014a, 30). ${ }^{10}$ Due cose vanno però notate. La prima è che un naturalismo inclusivo non ha, in quanto tale, meno mordente di un naturalismo esclusivo, anche se è sicuramente meno 'aggressivo'; il mordente del naturalista esclusivo potrebbe, infatti, essere, dal punto di vista di un naturalista inclusivo, poco più che una manifestazione di dogmatismo o di cecità filosofica. La seconda è che anche il naturalista più inclusivo non è disposto a includere tra i metodi legittimi e praticabili un presunto 'metodo filosofico' né è per nulla incline a concedere che la filosofia possa concorrere con la scienza (o con le varie scienze) mediante un proprio metodo a produrre «autentica conoscenza» (vedi Laudisa 2014, 4).

Allo stesso modo tutti i naturalismi, inclusivi o esclusivi, sembrano concordi nel ritenere che per la scienza non vi sono né dio né l'anima, se 'dio' e 'anima' sono i nomi di presunte entità non-naturali, soprannaturali o immateriali. Spiegare qualcosa ricorrendo a un

9 De Caro e Macarthur (2005, xv-xvi) chiamano 'naturalismo scientifico' il naturalismo più esclusivo e chiamano 'naturalismo liberalizzato' quella forma di naturalismo, «più aperta e pluralistica», la quale si distingue dal naturalismo scientifico «sia per la più inclusiva interpretazione di ciò che è 'naturale' [...] sia per la concezione più liberale dello statuto della scienza, del suo oggetto e dei suoi metodi».

10 Questo sarebbe il cosiddetto 'metodo ipotetico-deduttivo', il quale consiste nel «formulare ipotesi teoriche e verificare le loro predizioni mediante l'osservazione sistematica e l'esperimento controllato» (Williamson 2014a, 30). 
dio o un'anima non è una spiegazione, ma piuttosto una rinuncia alla spiegazione, ossia una rinuncia alla scienza e, dunque, alla conoscenza. Nel metodo scientifico a cui si appella il naturalista, sono, infatti, incorporate (anche se di rado esplicitate nel concreto processo dell'indagine scientifica) delle interdizioni, diciamo così, 'ontologiche'.11 Ciò sta a significare che ogni naturalismo, anche se formulato in termini puramente epistemologici (o metodologici), ha in sé una faccia ontologica che si potrebbe condensare nella formula, che sa indubbiamente un po' di filosofia prima, secondo cui 'essere è (o significa) natura'. Da questo punto di vista, la seconda critica di Williamson sembra mancare il bersaglio: anche il naturalismo più inclusivo è, per quanto riguarda il non-naturale, ${ }^{12}$ ben meno condiscendente di quanto egli ritenga. Certo, qualcuno potrebbe qui ricordarci, ${ }^{13}$ a sostegno di Williamson, l'equiparazione tra oggetti fisici e dei omerici fatta da Quine (1953; trad. it. 62-3) nelle righe conclusive di Due dogmi dell'empirismo. Secondo Quine, chi ritenga, come egli ritiene, che il nostro compito sia quello di «predire l'esperienza futura alla luce di quella passata», deve anche riconoscere che, rispetto a questo compito, «gli oggetti fisici e gli dei di Omero differiscono solo quanto al grado e non quanto al genere»; infatti, «[e]ntrambi questi tipi di entità entrano nella nostra concezione soltanto come postulati (posits) culturali [come miti]», anche se «[i]l mito degli oggetti fisici è epistemologicamente superiore alla maggior parte degli altri perché ha dimostrato maggior efficacia rispetto agli altri miti come strumento per modellare una struttura maneggevole all'interno del flusso dell'esperienza». È pero facile osservare o controbattere che qui gli dei omerici non hanno nulla di non-naturale (o di immateriale), altro non essendo, al pari degli oggetti fisici (pietre, alberi, montagne, ecc.), che dei miti o postulati culturali.

Per quanto riguarda, infine, la prima critica va osservato che non è difficile, nemmeno per il più 'duro' dei naturalisti, concedere che vi sono più cose di quelle che la scienza ha finora scoperto, ma anche di quelle che potrà mai scoprire. Una cosa non verrà scoperta semplicemente perché può essere scoperta. È vero, però, che per il naturalista, anche per il più inclusivo, appare assurdo domandarsi se vi possano essere cose che si possono scoprire solo con mezzi non-

11 Secondo Laudisa $(2014,6)$, «abbasso le entità sovrannaturali» è uno dei tre divieti che caratterizzano il naturalismo contemporaneo. Evidentemente, come precisa ancora Laudisa $(2014,6)$, si tratta di «un divieto di natura ontologica, dal momento che rappresenta una presa di posizione su come deve essere fatto ciò che esiste».

12 Questa osservazione vale se per 'non-naturale' intendiamo il sovrannaturale o l'immateriale nel senso più tradizionale (dio, anima, angeli, demoni, ecc.). Il senso di questa precisazione dovrebbe chiarirsi nel seguito.

13 Forse è proprio questo passo di Quine che Williamson ha presente nella sua seconda critica al naturalismo. 
scientifici. Considerare sensata questa domanda vorrebbe dire cessare di essere un naturalista. Possiamo illustrare questo punto con un richiamo a quello che Wittgenstein dice sulla distinzione tra miracolo ed evento straordinario. Secondo Wittgenstein, infatti, per la scienza non vi sono miracoli, ma solo eventi non ancora spiegati, ossia eventi che «non siamo ancora riusciti a raggruppare [...] insieme con altri in un sistema scientifico» (Wittgenstein 2014; trad. it., 16). Ciò però non sta a indicare che la scienza abbia provato che non ci sono miracoli, ma ci fa piuttosto capire che «il modo scientifico di guardare un evento non è il modo di guardarlo come un miracolo» (Wittgenstein 2014; trad. it., 17). Da questo punto di vista ha torto chi obiettasse al naturalista che non è affatto auto-evidente che non ci possano essere miracoli, ma avrebbe anche torto il naturalista che rispondesse che «il solo modo di cercare di rispondere a questa domanda ['Ci possono essere miracoli?'] è usare i metodi della scienza» (Rosenberg 2014a, 33).

\section{Maddy: un naturalismo austero}

Come Williamson, anche Penelope Maddy è arrivata alla conclusione che 'naturalismo' è un abito o troppo largo o troppo stretto. Va subito ricordato che, a differenza di Williamson, Maddy è una filosofa che si è sempre dichiarata, senza esitazioni, 'naturalista', tant'è vero che nel suo Naturalism in Mathematics (1997) si era impegnata a mostrare come il naturalismo si potesse estendere alla matematica. Per Maddy, insomma, il problema non era il naturalismo in quanto tale, ${ }^{14}$ ma il naturalismo in matematica, sicuramente uno dei grandi crucci di tutti i naturalisti. ${ }^{15}$ Tuttavia, quello che era dato per scontato nel 1997 appare problematico nel 2007, l'anno in cui pubblica Second Philosophy. Come infatti ella riconosce, ogni naturalista, così come ogni anti-naturalista, sembra ormai «coltivare una propria ferma nozione di ciò che il 'naturalismo' richiede» (Maddy 2007, vii); in questo modo però il termine si è quasi svuotato di significato, se mai ne è stato pieno, e sta ormai a indicare «poco più che una vaga simpatia per

14 Secondo la sua stessa testimonianza, nel volume sul naturalismo in matematica ella aveva dato per scontato «che tutti sapessero che cosa significa essere un naturalista» (Maddy 2007, vii).

15 «Una sfida al naturalismo è trovare un posto per la matematica. Le scienze naturali si basano su di essa, ma dovremmo considerarla una scienza di suo proprio diritto? Se lo facciamo, allora la descrizione del metodo scientifico appena data [il metodo scientifico come metodo ipotetico-deduttivo che formula ipotesi teoriche e verifica le loro predizioni con l'osservazione sistematica e l'esperimento controllato] è sbagliata perché non corrisponde alla scienza matematica che prova i suoi risultati mediante il puro ragionamento piuttosto che mediante il metodo ipotetico-deduttivo» (Williamson 2014a, 30). 
la scienza (science-friendliness)» (Maddy 2007, 1). ${ }^{16}$ Non per questo Maddy abbandona il suo naturalismo (si ricordi che il sottotitolo di Second Philosophy è A Naturalistic Method), ma persegue piuttosto lo scopo di delineare e praticare «una forma particolarmente austera di naturalismo» per la quale ha preferito coniare un nuovo termine, 'Filosofia seconda', proprio e soprattutto al fine di segnalare quanto questo suo naturalismo «differisca in modi sottili ma fondamentali dagli altri 'naturalismi'» (Maddy 2007, 1). In particolare, questo naturalismo 'austero' intende differenziarsi da tutti quei naturalismi che, cercando di definirsi mediante il richiamo alla scienza ${ }^{17} \mathrm{e}$ «lungo le linee 'fidati solo dei metodi della scienza'» (Maddy 2007, 1), mancano di riconoscere ciò che, «dopo decenni di studi in filosofia della scienza», dovrebbe essere evidente, ossia che «non c'è alcuna rigida specificazione di ciò che la 'scienza' deve essere e nessun determinato criterio della forma ' $x$ è scienza se e sole se...'» (Maddy 2007, 1). In questo senso, come ha osservato Stroud (2011, 254), il naturalismo austero sembra essere più liberale (open-minded) e meno dogmatico di gran parte dei naturalismi in circolazione in quanto «non si impegna in anticipo in nessuna definizione di 'scienza' né pone limiti al genere di cose che la scienza può scoprire».

Secondo Maddy, insomma, per fare filosofia secondo lo spirito della scienza non occorre né stabilire in anticipo che cosa sia scienza né sbaragliare preventivamente ogni scetticismo globale nei confronti della scienza e dei suoi metodi. Ciò significa che il naturalista austero abbandona in maniera radicale ogni pretesa di filosofia prima (non a caso si fa chiamare 'Filosofo secondo') e si affida, senza alcuna presunzione di fondarli, ai metodi della scienza al fine «di affrontare i problemi filosofici tradizionali - e [...] dar loro una risposta» (Maddy 2007, ix). Ne consegue che, per il Filosofo secondo, i problemi tradizionali della filosofia, o almeno una loro parte, possono e devono essere trasformati in problemi scientifici o riscritti come tali, ossia come problemi che possono essere affrontati e (eventualmente) risolti da questa o quella scienza o dal concorso di diverse scien-

16 Va notato che questa vaghezza e genericità del termine 'naturalismo' implica l'attribuzione agli anti-naturalisti di posizioni e atteggiamenti che comportano una netta separazione tra filosofia e scienza o, addirittura, la subordinazione della seconda alla prima. Infatti, se per essere naturalisti basta manifestare una vaga simpatia per la scienza, «[p]er essere qualificato come anti-naturalista, un pensatore contemporaneo deve insistere, per esempio, che l'epistemologia è una disciplina a priori che non ha niente da imparare dalla psicologia empirica o che le intuizioni metafisiche mostrano che la meccanica quantistica è falsa» (Maddy 2007, 1).

17 Come spiega Stroud (2011, 254), Maddy sostiene che «[1]e conclusioni raggiunte nella Filosofia seconda non sono difese in base all'autorità di qualcosa chiamato 'scienza' o sulla base di qualcosa chiamato 'Filosofia seconda' o 'naturalismo'». 
ze (Maddy 2007, 117). ${ }^{18}$ Per esempio, se deve affrontare il più tradizionale dei problemi epistemologici: 'Come arriviamo a conoscere il mondo?', la reazione del Filosofo secondo sarà quella di rivolgersi alla scienza cognitiva contemporanea e di cercare delle risposte non nei trattati di epistemologia che parlano di 'dati', 'teoria' o 'prova' (evidence), ma, per esempio, negli «studi su come gli infanti nella fase prelinguistica arrivano a percepire e a rappresentare gli oggetti fisici» (Maddy 2007, 90).

Com'è evidente, il Filosofo secondo di Maddy intende distinguersi sia dal naturalista per cui l'appello alla scienza è, per così dire, l'ultima parola della filosofia prima sia dal filosofo che ritiene che filosofia sia analisi o ricerca concettuale a priori, ${ }^{19}$ da praticare in poltrona e non nei laboratori. ${ }^{20}$ Secondo questa concezione, che molta filosofia analitica condivide con Wittgenstein, ${ }^{21}$ i problemi filosofici non sarebbero, infatti, problemi empirici o scientifici, ossia problemi che «si risolvono [...] producendo nuove esperienze», bensì, per l'appunto, problemi 'concettuali' o 'linguistici' «che si risolvono penetrando l'operare del nostro linguaggio [perlustrando il nostro sistema di concetti] in modo da riconoscerlo, contro una forte tendenza a fraintenderlo» (Wittgenstein 1953, trad. it. § 109). Per chi guarda così alla filosofia, è chiaro che ogni pretesa di riscrivere come scientifico un problema filosofico costituirebbe un vero e proprio errore categoriale. La conclusione che molti ne hanno tratto è che la filosofia è e deve rimanere del tutto indifferente ai metodi e risultati della

18 Marconi $(2012,21-2)$ ritiene che due siano i modi in cui la proposta di Maddy può essere interpretata. Secondo il primo modo «i problemi filosofici devono essere sostituiti da problemi scientifici»; in base al secondo, che Marconi ritiene sia l'orientamento che prevale in Maddy, «ci sono versioni scientifiche dei problemi filosofici tradizionali», per cui «[t]rattare un problema filosofico come problema scientifico significa, presumibilmente, cercare di rispondere a una domanda tradizionalmente considerata filosofica appellandosi soltanto a conoscenze scientifiche e facendo uso soltanto dei metodi della scienze».

19 Questo è anche l'obiettivo che persegue Williamson 2007; come osserva Marconi $(2012,7)$, lo scopo dichiarato di questo libro «è di contestare la tesi, largamente diffusa almeno in ambito analitico, secondo cui la ricerca filosofica è ricerca concettuale. Se una ricerca concettuale è una ricerca che verte sui concetti, allora, nota Williamson, è abbastanza raro che una ricerca filosofica sia concettuale».

20 «Naturalmente, il laboratorio è la patria del Filosofo secondo» (Maddy 2007, 91). A differenza di Maddy, Williamson ritiene che negare che la filosofia sia ricerca concettuale condotta a priori e sostenere che un problema filosofico debba essere affrontato ricorrendo a tutti i metodi e le conoscenze che si hanno a disposizione non significa che la filosofia si possa fare solo nei laboratori e che la figura del filosofo si identifichi con quella dello scienziato.

21 Ovviamente, molta filosofia analitica, per non dire la gran parte, non condivide né lo spirito (dissolutivo) né il modo (frammentario e asistematico) della ricerca concettuale di Wittgenstein. 
scienza. ${ }^{22}$ Un filosofo in laboratorio farebbe solo ridere. Le critiche che sia Williamson che Maddy ${ }^{23}$ rivolgono a una siffatta conclusione vanno sicuramente prese sul serio. A sua volta, un naturalista austero dovrebbe però ammettere che le scienze possono talora aver bisogno di qualcosa di molto simile a un'analisi o a una ricerca concettuale. Si pensi, per fare uno degli esempi più noti, agli esperimenti di Benjamin Libet. Potremmo dire, seguendo Maddy, che i risultati sperimentali di Libet (vedi, per esempio, Libet 2004) sono una risposta scientifica, perché data sulla base di esperimenti e non di ricerche condotte in poltrona sui concetti di azione, coscienza, libero arbitrio, ecc., al problema che la tradizione filosofica aveva espresso in domande come: 'Esiste il libero arbitrio?' o 'Siamo noi che diamo liberamente (e consapevolmente) inizio alle nostre azioni?'. E tuttavia, riconosciuta, contro ogni 'purismo' filosofico, l'importanza dei risultati sperimentali di Libet e la necessità di confrontarsi con essi, non si può evitare di riconoscere che nel formulare il problema, nel progettare gli esperimenti, nell'istruire i soggetti sperimentali e, soprattutto, nell'interpretare significato e conseguenze dei risultati, ossia nello stabilire che cosa si sia veramente provato, ${ }^{24}$ Libet ha usato una lingua e impiegato dei concetti che 'precedono' gli esperimenti e che, detto nella maniera più diretta, richiedono di essere chiariti. ${ }^{25}$

\section{Il naturalismo tra epistemologia e ontologia}

Come sappiamo, vi sono in letteratura molti e diversi tentativi di definire o caratterizzare il naturalismo e di dare una risposta il più possibile informativa a domande come le seguenti: 'Che cosa è il naturalismo?' o 'Che cosa significa (che cosa comporta o a che cosa impegna) essere naturalisti?'. Molte di queste risposte sono di tipo

22 Che questo sia l'atteggiamento di Wittgenstein è dato per scontato, sulla base di molte evidenze testuali, da gran parte degli interpreti. Va però osservato che una cosa è negare, come Wittgenstein indubbiamente fa, che i problemi filosofici siano problemi scientifici, altra cosa è dichiararsi filosoficamente indifferente ai metodi e ai risultati della scienza.

23 Con questo non intendo cancellare ogni differenza tra l'approccio di Williamson e quello di Maddy.

24 I risultati di Libet avrebbero dimostrato che «[n]on è il libero arbitrio cosciente a dare inizio alle nostre azioni liberamente volontarie, quanto quello che Libet chiama un 'borbottare' del cervello» (Chiereghin 2008, 284). Che gli esperimenti di Libet provino che non c'è il libero arbitrio è la conclusione che alcuni, ma non Libet, hanno tratto.

25 Assumiamo che gli esperimenti di Libet abbiano dimostrato che non c'è qualcosa come il libero arbitrio. Non è legittimo (e importante) domandarsi che cosa abbiano provato che non c'è? E non è altrettanto legittimo (e importante) domandarsi quali conseguenze tutto questo abbia per tutti quei concetti (responsabilità, colpa, merito, ecc.) che sembrano connessi a quello di libero arbitrio? 
epistemologico; di questo tipo è, per esempio, la risposta che dà Rosenberg allorché afferma che «[i]l naturalismo è la teoria filosofica che tratta la scienza come la nostra più affidabile fonte di conoscenza e il metodo scientifico come la via più efficace alla conoscenza» (Rosenberg 2014a, 32) o quando precisa che «[n]aturalismo è l'etichetta per la tesi che gli strumenti che dovremmo usare nel rispondere ai problemi filosofici sono i metodi e i risultati delle scienze mature - dalla fisica alla biologia e, sempre di più, alle neuroscienze» (Rosenberg 2014b, 17). In questo senso di naturalismo, un naturalista è qualcuno che (1) sostiene che non vi è un metodo filosofico distinto da quello scientifico; ${ }^{26}(2)$ rigetta tutte quelle risposte alle questioni filosofiche che siano incompatibili con i risultati scientifici o che vogliano competere con essi; ${ }^{27}$ (3) lascia cadere ogni scetticismo (globale e sistematico) riguardo alla scienza e qualsiasi dubbio o sospetto che «ci siano fatti riguardo alla realtà che la scienza non può afferrare» (Rosenberg 2014b, 17); ${ }^{28}$ (4) afferma che non è la filosofia che può darci la garanzia anti-scettica che le nostre pretese alla conoscenza sono effettive. ${ }^{29}$ Sulla base di quanto appena detto, non è difficile arrivare alla conclusione che il naturalismo epistemologico attesta il momento in cui la filosofia passa il testimone della conoscenza alla scienza riconoscendo che la rivoluzione scientifica è giunta finalmente al suo compimento. ${ }^{30}$

Quello che abbiamo finora considerato è l'aspetto epistemologico del naturalismo; ma, come abbiamo già intravisto, il naturalismo ha anche un altro aspetto: l'aspetto che possiamo chiamare 'ontologico'. ${ }^{31} \mathrm{I}$ due aspetti sono chiaramente individuati e distinti, per esempio, da Wil-

26 Il che significa, semplicemente, che vi è solo il metodo scientifico. Secondo Price (2004, 71; trad. it., 58), «essere un naturalista filosofico significa come minimo ritenere che la filosofia non sia del tutto diversa dalla scienza e che la prima debba rimettersi al giudizio della seconda, laddove gli interessi delle due discipline coincidano» (Price 2004, 71; trad. it., 58).

27 Per esempio, dopo gli esperimenti di Libet a nessun filosofo è più concesso, secondo i naturalisti, affermare che noi siamo liberi o dichiararsi a favore del libero arbitrio. In realtà, un naturalista aggiungerebbe qualcosa come 'allo stato delle nostre conoscenze scientifiche'.

28 In questo senso il naturalista può «asserire con sicurezza che, allo stato attuale dello sviluppo della scienza, l'assenza di una prova è prima facie una fondata prova di un'assenza: questo vale per Dio e per moltissimo altro» (Rosenberg 2014b, 17).

29 È questo il senso (o almeno uno dei sensi) che molti naturalisti danno al loro proclama che non vi è o non si dà filosofia prima.

30 «[I]l naturalismo dipende in modo essenziale da un modello di conoscenza di origine strettamente scientifica e, più in generale, dal ruolo di paradigma della conoscenza che la scienza ha assunto negli ultimi tre secoli» (Laudisa 2014, 4).

31 Come osserva Stroud (2011, 224-5), «dobbiamo distinguere due aspetti del naturalismo. C'è il naturalismo come concezione di ciò che è così o del modo in cui in le cose sono o di ciò che c'è nel mondo. E c'è il naturalismo come un modo di studiare o di indagare ciò che è così nel mondo. [...] Ovviamente, il modo in cui pensi che il mondo 
liamson $(2014 \mathrm{a}, 29)$ allorché osserva che un filosofo che si descrive come naturalista vuol dirci che egli crede almeno in queste due cose: in termini ontologici che «c'è solo il mondo naturale» e, in termini epistemologici, che «il modo migliore di fare scoperte su di esso è mediante il metodo scientifico». Una distinzione analoga è fatta da Rea (2004, 22-3) quando osserva che «[i]l naturalismo è stato sempre associato con due progetti [...]. Il primo progetto è quello di cercare di condurre ogni teorizzazione filosofica in accordo con i metodi e i risultati delle scienze naturali. Il secondo è quello di cercare di comprendere il mondo il più possibile in termini compatibili con assunzioni materialiste».32 Ovviamente, niente esclude, in astratto, che si possa credere in una cosa senza credere nell'altra o aderire a un progetto senza abbracciare l'altro. Per esempio, qualcuno ${ }^{33}$ potrebbe credere che il metodo scientifico sia il modo migliore di indagare il mondo naturale, ma allo stesso tempo non credere che ci sia solo il mondo naturale; allo stesso modo, qualcuno potrebbe credere che vi sia solo il mondo naturale, ma non che il metodo scientifico sia il solo o il miglior modo di indagarlo. ${ }^{34}$ Qualcuno, ma di certo non un naturalista 'duro'. Per quest'ultimo, infatti, il mondo naturale altro non è che il mondo della scienza e, quasi sempre, di quella scienza che è la fisica. Come osserva Rosenberg (2014b, 19), la metafisica ${ }^{35}$ del naturalista «è [...] data da ciò che la fisica ci dice sull'universo»; ; ${ }^{36}$ ciò significa che, secondo questo naturalismo, i fatti fisici «determinano o 'fissano' tutti gli altri fatti sulla realtà e su ciò che esiste nell'universo o ogni altro fatto se, come la fisica può giungere a mostrare, ce ne sono altri. [...] $]^{37} \mathrm{E}$ se la fisica non può in principio fissare un presunto fatto, esso non è, dopo tutto, un fatto».

In sintesi, possiamo dire che per quanto riguarda il rapporto tra epistemologia e ontologia si possono rintracciare due posizioni, ognuna con i propri problemi da risolvere.$^{38}$ Secondo la posizione ampiamen-

sia influenzerà il modo in cui indaghi le cose che sono in esso e su quella che ritieni sia la maniera migliore di comprenderle. I due aspetti del naturalismo sono connessi».

32 Qui possiamo considerare 'materiale' un sinonimo di 'naturale'. Questo non vuol dire che 'naturale' e 'materiale' siano sempre da considerarsi sinonimi.

33 Per esempio, qualcuno che fosse un dualista di tipo cartesiano.

34 Per esempio, qualcuno che fosse un filosofo della natura di stampo goethiano.

35 Qui Rosenberg chiama 'metafisica' ciò che nel testo ho chiamato 'ontologia'. Per i presenti scopi non è necessario che ci soffermiamo su questa differenza terminologica.

36 Questo tipo di naturalismo che assegna un ruolo fondamentale alla fisica è talvolta chiamato 'fisicalismo'. Anche se molti naturalisti sono fisicalisti, si può essere naturalisti senza essere fisicalisti.

37 Rosenberg $(2014 \mathrm{~b}, 19)$ ritiene che lo stesso punto possa essere stabilito usando il concetto di sopravvenienza: «Un altro modo di esprimere che è la fisica che fissa i fatti consiste nel dire che tutti gli altri fatti - i fatti chimici, biologici, psicologici, sociali, economici, politici, culturali - sopravvengono sui fatti fisici e sono spiegati da essi».

38 Che qui non saranno discussi. 
te maggioritaria il naturalismo ontologico è, per così dire, incorporato nel naturalismo epistemologico. I due naturalismi sono, insomma, il verso e il recto dello stesso foglio e la dualità tra ontologia ed epistemologia si rivela essere solo presunta o illusoria (Laudisa 2014, 19). ${ }^{39}$ Secondo l'altra posizione l'epistemologia conta per il naturalismo di più dell'ontologia (vedi Rea 2004, 23) e, in ogni caso, nel naturalismo epistemologico non è incorporata alcuna specifica ontologia materialistica o naturalistica. ${ }^{40}$ In questo senso un naturalista epistemologico può non essere, per quanto riguarda l'ontologia, un naturalista. L'unica via che sembra sbarrata per il naturalista è quella che va dall'ontologia all'epistemologia. Un naturalismo puramente ontologico, infatti, non farebbe altro che evocare quello spettro della filosofia prima che ogni naturalista sembra da sempre impegnato a esorcizzare.

\section{$5 \quad$ Naturalismo 'duro' e naturalismo 'soffice'}

Secondo Strawson $(1985,1)$ possiamo distinguere due differenti generi di naturalismo: il naturalismo che egli chiama 'duro' (hard) o anche 'stretto o riduttivo' e quel naturalismo che egli chiama 'soffice' (soft) o anche 'cattolico o liberale'. ${ }^{41}$ Il naturalismo così come lo intende Rosenberg (2014a e 2014b), è sicuramente un naturalismo 'duro', anche se egli preferisce chiamarlo 'senza illusioni' o 'disincantato' (Rosenberg 2014b, 17) allo scopo di sottolineare almeno le due seguenti cose. La prima è che, se si è naturalisti conseguenti, occorre, in sintonia con la scienza, ${ }^{42}$ "dire no in risposta a molte questioni alle quali quasi tutti sperano che la risposta sia sì (Rosenberg 2014b, 17). Per esempio, se si riconosce, come Rosenberg ritiene che un naturalista debba fare, che i fatti fisici fissano tutti i fatti o, quantomeno, che tutti gli altri fatti sopravvengono su quelli fisici, allora bisogna accettare che non vi sono fini o scopi né nella biologia né nelle vicende umane né nei nostri processi di pensiero (vedi Rosenberg

39 Secondo Koppelberger (1999, 32), il naturalismo ontologico non fa altro che «evidenziare e analizzare gli impegni e le implicazioni metafisiche delle teorie scientifche» muovendo dall'assunto che «non esiste alcun modo extra-scientifico per una comprensione metafisica».

40 Anche se, dal punto di vista storico, naturalismo epistemologico e naturalismo ontologico sono spesso presentati insieme.

41 Anche De Caro e Macarthur (2005, xv e 279) distinguono, con intenzioni in parte simili, il naturalismo in scientifico e liberalizzato. Sulle orme di John McDowell (1996), McGinn $(2014,65)$ oppone a un naturalismo scientifico, restrittivo, un naturalismo liberale che ben si adatta, a suo parere, a caratterizzare l'atteggiamento filosofico di fondo di Wittgenstein.

42 «Io penso che il naturalismo sia corretto, ma penso anche che la scienza ci imponga di 'assumere un atteggiamento' privo di ogni illusione (disillusioned) nei riguardi della realtà» (Rosenberg 2014b, 17). 
2014b, 19). E quello che si è detto dei fini o scopi vale anche e con la stessa nettezza per altre cose come «il significato della vita, i fondamenti della moralità, la rilevanza della coscienza, il carattere del pensiero, la libertà del volere, i limiti dell'auto-comprensione umana e la traiettoria della storia umana» (Rosenberg 2014b, 17). Per esempio, un naturalista conseguente ${ }^{43}$ è, per quanto riguarda la morale, un nichilista che riconosce che «non ci può essere alcuna conoscenza morale» (Rosenberg 2014b, 23) ed è, in metafisica, un determinista che considera il libero arbitrio niente altro che un'illusione. ${ }^{44}$

La seconda cosa a cui Rosenberg mira parlando di naturalismo 'senza illusioni' o 'disincantato' è indurci a considerare la scienza moderna un 'punto di non ritorno'. Una volta affermatasi, la scienza moderna non tollera esitazioni o ripensamenti né ci concede di tornare, se non illusoriamente, al mondo 'incantato' della pre-modernità. Il mondo della scienza è, insomma, quel mondo 'disincantato' di cui aveva parlato Max Weber. Secondo Weber (1919; trad. it. 20), infatti, disincantato è il mondo in cui domina «la coscienza o la fede che [...] ogni cosa - in linea di principio - può essere dominata con la ragione. Non occorre più ricorrere alla magia per dominare o per ingraziarsi gli spiriti, come fa il selvaggio per il quale esistono simili potenze. A ciò sopperiscono la ragione e i mezzi tecnici» (Weber 1919; trad. it. 20). ${ }^{45}$ Insomma, per dirla un po' grossolanamente, il mondo disincantato è quel mondo in cui, se sto male, vado dal medico e non dallo sciamano e se l'automobile non parte non mi rivolgo allo stregone, ma al meccanico. Come ha

43 Un naturalismo conseguente è un naturalismo che si basa in maniera esclusiva sul metodo e i risultati della scienza. Un naturalismo di questo tipo Rosenberg lo chiama anche 'scientismo': "Scientismo è la mia etichetta per ciò che chiunque prenda la scienza seriamente dovrebbe credere» (Rosenberg 2014b, 18).

44 Il determinismo e la negazione di un effettivo libero arbitrio sono cose che, per un naturalista, «vanno da sé» (Rosenberg 2014b, 25). Altrettanto illusorie del libero arbitrio sono, per il naturalista, l'intenzionalità o la coscienza. «Che l'intenzionalità conscia sia un'illusione è qualcosa di cui lo scientismo [il naturalismo conseguente] può essere sicuro. [...] La mente è il cervello. I pensieri consci, esattamente come quelli inconsci, sono combinazioni complesse di cellule neuronali con ioni e macromolecole che si muovono tra di esse» (Rosenberg 2014b, 27); «Se la mente è il cervello (e lo scientismo non può concedere che sia qualcosa di diverso), dobbiamo finirla di prendere seriamente la coscienza come una fonte di conoscenza o di comprensione della mente o del comportamento prodotto dal cervello» (Rosenberg 2014b, 29).

45 Si ricordi che, per Weber (1919; trad. it., 19), ciò non significa che «oggi noi [...] abbiamo una conoscenza delle condizioni di vita nelle quali esistiamo maggiore di quella di un indiano o di un ottentotto». Noi, infatti, prendiamo il tram senza sapere, e senza aver bisogno di sapere, come la vettura riesca a mettersi in moto o spendiamo del denaro anche se non sappiamo rispondere alla domanda su «come avvenga che qualcosa - ora poco, ora molto - possa essere comprato col denaro». Tuttavia, tutti noi, quando prendiamo un tram o spendiamo del denaro, crediamo che la scienza (e solo la scienza) sappia spiegare perché un tram si muove e che la tecnica (e solo la tecnica) basata sulla scienza sappia costruire un tram che si muove nella città secondo i nostri bisogni di spostamento. 
scritto McDowell (1996, 71; trad. it., 76), ${ }^{46}$ disincantato (senza 'incanto' e 'significato') è quel mondo in cui la natura viene progressivamente identificata "con ciò che la scienza naturale mira a rendere comprensibile», ossia con quello che McDowell chiama 'il Regno della Legge'.47

Ovviamente, anche un naturalista à la Rosenberg sa bene che domande come 'Siamo liberi?' o 'Qual è il significato della vita?' o 'Come dobbiamo agire?' sono domande persistenti e difficili da eludere, domande che, per così dire, non ci fanno dormire (vedi Rosenberg 2014b, 18). E sa anche che molte delle risposte che la scienza ci dà non sono le risposte che vorremmo sentire e che sono spesso difficili da comprendere (vedi Rosenberg 2014b, 17-18). Vi è nel naturalismo qualcosa di ben poco consolatorio. Proprio per questo, secondo Rosenberg (2014b, 17), molti naturalisti «hanno cercato di riconciliare la scienza con il senso comune 0 con l'immagine manifesta ${ }^{48} \mathrm{o}$ con la saggezza della nostra cultura» e lo hanno fatto cercando di «evitare o, quantomeno, di qualificare, reinterpretare o rimodellare [...] le sgradevoli conclusioni della scienza». Che vi sia stata questa tendenza è, del resto, abbastanza comprensibile una volta che ci si è resi conto che il naturalismo 'duro' relega nel non-naturale non solo dei, demoni e spiriti, ma anche moltissime altre cose a cui è sicuramente più arduo rinunciare: sentimenti, colori, norme, significati, valori, intenzioni, ecc., e che nella lingua del Regno della Legge non si possono dire cose come: 'Sono triste', 'Ti sei comportato molto male', 'Questa norma è ingiusta', 'Che intenzioni hai?', 'Non puoi sfuggire alle tue responsabilità!', 'La parete è rossa', 'Che cosa significa questa parola?', 'A che cosa starà pensando?', 'Perché non hai mantenuto la parola data?', 'Si amano ancora', ecc.

Come abbiamo visto, la risposta di Rosenberg è: tanto peggio per i sentimenti, le norme, le intenzioni, i colori, ecc. La risposta di quello che McDowell (1996, 72; trad. it., 78) chiama 'il crudo naturalismo' (bald naturalism) è, invece, di tipo riduzionista. ${ }^{49}$ Per esempio, il na-

46 McDowell $(1996,76)$ si richiama esplicitamente a Max Weber.

47 Come ben riassume Wright $(2002,140)$, secondo McDowell la concezione oggi dominante «innalza il tipo di descrizione del mondo offerta dalla scienza fisica moderna in una metafisica di ciò che il mondo naturale nella sua essenza è: un 'Regno della Legge' - un dominio della connessione causale-nomologica da cui sono assenti e significato e che può essere descritto in maniera completa senza bisogno di alcun vocabolario che riguardi le menti e loro attività».

48 La distinzione tra immagine manifesta e immagine scientifica si trova, com'è noto, in Sellars (1963). Così la differenza tra le due immagini è riassunta da Overgaard, Gilbert e Burwood $(2013,60)$ : «[L]' immagine manifesta' si riferisce all'immagine del mondo che ci è offerta dal senso comune scientificamente illuminato. [...] Ma essa non è l'immagine scientifica - questa seconda essendo il genere di immagine del mondo che otteniamo, per esempio, dalla biologia molecolare, dalla chimica e, in particolare, dalla fisica».

49 La risposta che abbiamo attribuito a Rosenberg è, invece, di tipo eliminazionsita. Come osserva Wright $(2002,140)$, «eliminazionista è la risposta che consiste semplicemente nel ripudiare la pretesa di quelle categorie [per esempio, le categorie di significato, intenzionalità e normatività] di rappresentare qualcosa di reale». 
turalista riduzionista ritiene che gli atteggiamenti umani che appaiono valutativi ('Quell'azione è giusta' o 'Questa statua è bella') siano, dopo tutto, «atteggiamenti con dei contenuti che possono valere e valgono nel mondo naturale in senso stretto. Essi possono essere veri o falsi, ma le condizioni della loro verità sono puramente naturali e, perciò, non-valutativi» (Stroud 2011, 234). La scommessa di McDowell, come di altri naturalisti 'liberali' ${ }^{50}$ è che non si debba essere costretti a scegliere tra naturalismo, poco importa se eliminazionista o riduzionista, e soprannaturalismo o platonismo rampante. ${ }^{51}$ In varie forme, ciò che caratterizza i vari naturalismi liberali ${ }^{52}$ è (1) l'adesione decisa, per quanto riguarda la scienza e i suoi metodi, a una forma di pluralismo. Insomma, nessun naturalista liberale è disposto a sottoscrivere con Quine $(1981,93)$ l'affermazione secondo cui, mentre la fisica «indaga la natura essenziale del mondo», le altre scienze come la biologia descrivono solo «una protuberanza (bump) locale» e le scienze umane o sociali come la psicologia addirittura solo «la protuberanza di una protuberanza»; ${ }^{53}$ (2) il rifiuto conseguente di identificare la natura «con ciò che la scienza naturale mira a rendere comprensibile» (McDowell 1996, 71; trad. it, 76); (3) il riconoscimento che non vi è niente di non-naturale (o di soprannaturale) $)^{54}$ nei nostri comportamenti e nei nostri diversi modi di descrivere, per esempio, un atto come (in)giusto o un'azione come (ir)responsabile

50 Alcuni, per esempio McGinn (2014) e Overgaard, Gilbert, Burwood (2013, 57-60), includono tra i naturalisti liberali il cosiddetto 'secondo' Wittgenstein. Anche se consapevoli che Wittgenstein avrebbe rifiutato questa come, del resto, qualsiasi altra etichetta filosofica, questi interpreti sembrano ritenere che lo spirito e il clima della sua filosofia siano affini o in sintonia con quello che essi chiamano 'naturalismo liberale'.

51 Di fronte al crudo naturalismo vi può essere la tentazione di rifugiarsi in quello che McDowell (1996, 77-8; trad. it., 83-4) chiama 'soprannaturalismo' o 'platonismo sfrenato' (rampant platonism). Per questo platonismo le cose che il crudo naturalismo vuole ridurre sono irriducibili e vanno concepite come «una struttura autonoma - autonoma in quanto costituita indipendentemente da qualsiasi cosa specificamente umana, perché ciò che è specificamente umano è sicuramente naturale». Come osserva Wright (2002, 141), il platonismo rampante rappresenta «una ipostatizzazione metafisica e oscurantista» del significato, dell'intenzionale e del normativo. McDowell rigetta questo platonismo rampante e, tra le altre cose, gli rimprovera di condividere con il naturalismo la concezione puramente scientifica della natura.

52 Liberale può essere considerato anche il naturalismo soggettivo di Huw Price (vedi, per esempio, Price 2011) il quale, come sottolinea Knowles $(2018,291)$, «prende come suo punto di partenza una concezione degli umani come esseri naturali e evoluti in un ambiente naturale».

53 Sul senso e le implicazioni di questa e di altre prese di posizione di Quine vedi di Coates (1996, 31-8).

54 Per esempio, un naturalista liberale come McDowell «mira a mostrare come il significare, il comprendere e il pensare siano poteri naturali degli esseri umani che sono stati esposti a un certo tipo di educazione ordinaria» (McGinn 2014, 65). 
o una condotta come (in)giustificata; ${ }^{55}$ (4) il rigetto, di conseguenza, dell'«idea che sia solo attraverso i metodi della scienza naturale che si possa dire qualcosa di interessante e di importante sul mondo (naturale) nel quale viviamo» (Overgaard, Gilbert, Burwood 2013, 60). In questo senso, un naturalista liberale può essere, ontologicamente, un naturalista anche se non è un naturalista epistemologico.

\section{Bibliografia}

Chiereghin, Franco (2008). «La coscienza: un ritardato mentale?». Verifiche, 37(4), 283-316.

Coates, John (1996). The Claims of Common Sense. Moore, Wittgenstein, Keynes and the Social Sciences. Cambridge: Cambridge University Press. DOI https://doi.org/10.1017/cbo9780511520020.

De Caro, Mario; Macarthur, David (2005). La mente e la natura. Per un naturalismo liberalizzato. Roma: Fazi.

Haug, Matthew C. (ed.) (2014). Philosophical Methodology: The Armchair or the Laboratory? New York; London: Routledge.

Kim, Jaegwon (2003). "The American Origins of Philosophical Naturalism». Journal of Philosophical Research, APA Centennelial Volume, 83-98. DOI https://doi.org/10.5840/jpr200328supplement28.

Kitcher, Philip (2012). Preludes to Pragmatism. Toward a Reconstruction in Philosophy. Oxford: Oxford University Press. DOI https://doi.org/10.1093/

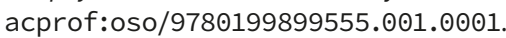

Knowles, Jonathan (2018). «Representationalism, Metaphysics, Naturalism. Price, Horwich, and Beyond». Cahill, Kevin M.; Raleigh, Thomas (eds), Wittgenstein and Naturalism. London; New York: Routledge, 287-308. DOI https://doi.org/10.4324/9781315301594-14.

Koppelberger, Dirk (1999). «What is Naturalism Today - and What It Should It be Tomorrow?». Marconi, Diego (a cura di), Naturalismo e naturalizzazione. Vercelli: Mercurio, 23-45.

Laudisa, Federico (2014). Naturalismo. Filosofia, scienza, mitologia. Roma-Bari: Laterza.

Libet, Benjamin (2004). Mind Time. The Temporal Factor in Consciousness. Cambridge (MA): Harvard University Press. Trad. it.: Mind Time. Il fattore temporale della coscienza. Trad. di Pier Daniele Napolitani. Milano: Cortina, 2007.

Maddy, Penelope (1997). Naturalism in Mathematics. Oxford: Oxford University

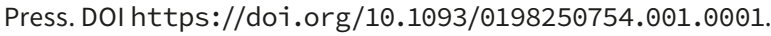

Maddy, Penelope (2007). Second Philosophy. A Naturalistic Method. Oxford: Oxford University Press. DOIhttps://doi.org/10.1093/acprof:o

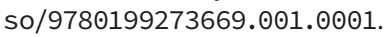

Marconi, Diego (2012). «Tre immagini della filosofia». Rivista di Filosofia, CIII(3), 1-28.

55 Per i naturalisti liberali, insomma, «possiamo accettare il significare, il pensare, l'intendere, ecc., come aspetti delle nostre vite naturali, senza cercare di fondarli in fatti non-normativi» (McGinn 2014, 65). 
McDowell, John (1996). Mind and World. Cambridge (MA): Harvard University Press. DOI https://doi.org/10.1111/0029-4624.00099. Trad. it.: Mente e mondo. Trad. di Carlo Nizzo. Torino: Einaudi, 1999.

McGinn, Maria (2014). «Liberal Naturalism: Wittgenstein and McDowell». Haug 2014, 62-75.

Moore, George E. (1903). Principia Ethica. London: Cambridge University Press. Overgaard, Søren; Gilbert, Paul; Burwood, Stephen (2013). An Introduction to Metaphilosophy. Cambridge: Cambridge University Press. DOI https:// doi.org/10.1017/cbo9781139018043.

Price, Huw (2004). «Naturalism Without Representationalism». De Caro, Mario; Macarthur, David (eds), Naturalism in Question. Cambridge (MA): Harvard University Press, 71-88. Trad. it.: «Naturalismo senza rappresentazionalismo». Trad. di Gianfranco Pellegrino. La mente e la natura. Per un naturalismo liberalizzato. Roma: Fazi, 2005, 58-77.

Price, Huw (2011). Naturalism Without Mirrors. Oxford: Oxford University Press.

Quine, Willard V.O (1953). From a Logical Point of View: Nine Logico-Philosophical Essays. Cambridge (MA): MIT Press. Trad. it.: Da un punto di vista logico. Saggi logico-filosofici. Trad. di Paolo Valore. Milano: Cortina, 2004.

Quine, Willard V.O. (1969). Ontological Relativity and Other Essays. New York: Columbia University Press. Trad. it.: La relatività ontologica e altri saggi. Trad. di Michele Leonelli. Roma: Armando, 1986.

Quine, Willard V.O. (1981). Theories and Things. Cambridge (MA): Belnkap.

Ramberg, Bjørn Torgrim (2018). «Do Pragmatic Naturalists Have Souls? Should Anyone Be Paid to Worry About it?». Cahill, Kevin M.; Raleigh, Thomas (eds), Wittgenstein and Naturalism. New York; London: Routledge, 309-28. DOI https://doi.org/10.4324/9781315301594-15.

Rea, Michael C. (2004). World Without Design. The Ontological Consequences of Naturalism. Oxford: Clarendon Press. DOI https://doi.org/10.1093/๑ 199247609.001.0001.

Rosenberg, Alexander (2014a). «Why I Am a Naturalist». Haug 2014, 32-5.

Rosenberg, Alexander (2014b). «Disenchanted Naturalism». Bashour, Bana; Muller, Hans D. (eds), Contemporary Philosophical Naturalism and Its Implications. New York; London: Routledge, 17-36.

Russell, Bertrand (1921). The Analysis of Mind. London: Allen \& Unwin.

Sellars, Wilfrid (1963). Science, Perception and Reality. London: Routledge \& Kegan Paul.

Strawson, Peter F. (1985). Skepticism and Naturalism: Some Varieties. London: Methuen.

Stroud, Barry (2011). Philosophers Past and Present. Selected Essays. Oxford: Clarendon Press. DOI https://doi.org/10.1093/acprof:o so/9780199608591.001.0001.

Weber, Max (1919). Wissenschaft als Beruf. München; Leipzig: Duncker \& Humblot. Trad.it.: Il lavoro intellettuale come professione. Trad. di Antonio Giolitti. Torino: Einaudi, 1976.

Williamson, Timothy (2007). The Philosophy of Philosophy. Oxford: Wiley-Blackwell. DOI https://doi.org/10.1002/9780470696675.

Williamson, Timothy (2014a). «What is Naturalism?». Haug 2014, 29-31.

Williamson, Timothy (2014b). «The Unclarity of Naturalism?». Haug 2014, 36-8. Wittgenstein, Ludwig (1953). Philosophical Investigations. Oxford: Basil Blackwell. Trad. it.: Ricerche filosofiche. Trad. di Renzo Piovesan e Mario Trinchero. Torino: Einaudi, 1967. 
Wittgenstein, Ludwig [1921-1922] (1989). Tractatus logico-philosophicus. Trad. it. di Amedeo G. Conte. Torino: Einaudi.

Wittgenstein, Ludwig (2014). Lecture on Ethics. Ed. by Edoardo Zamuner, Ermelinda V. Di Lascio, David K. Levy. Oxford: Wiley Blackwell. DOI https://doi. org/10.1002/9781118887103. Trad. it.: Lezioni e conversazioni sull'etica, l'estetica, la psicologia e la credenza religiosa. Trad. di Michele Ranchetti. Milano: Bompiani, 1987.

Wright, Crispin (2002). «Human Nature?». Smith, Nicholas H. (ed.), Reading McDowell: On Mind and World. London; New York: Routledge, 140-159. 



\title{
La natura e gli stati abituali nell'Etica Nicomachea Analogie e differenze
}

\section{Flavia Farina}

Università degli Studi Roma Tre - Tor Vergata, Italia; Université Paris 1

Panthéon-Sorbonne, France

\begin{abstract}
According to Aristotle, virtue does not arise in us neither by nature nor contrary to nature. 'Virtue naturalism', as the possibility to 'reduce' virtue and virtues of character to physical or physiological entities and relations, seems consequently impossible. Nature and virtue differ mostly in respect of their relation with contraries. A moral agent can become either virtuous or vicious, while a stone can only move downwards. However moral habits, once acquired by the agent, seem to come close to nature's uni-directionality.
\end{abstract}

Keywords Nicomachean Ethics. Habits. Virtue. Naturalism. Nature. Aristotle. Uni-directionality.

Sommario 1 Introduzione. - 2 Né per natura né contro natura: l'acquisizione della virtù. - 3 La necessità dei processi naturali e la 'necessità qualitativa' delle azioni. 4 Conclusioni.

\section{Introduzione}

Aristotele nell'Etica Nicomachea afferma che «nessuna virtù morale nasce in noi per natura» (Eth. Nic., II, 1 1103a 19-20; trad. it. Natali).

Sembrerebbe dunque, da questa affermazione, quasi impossibile attribuire ad Aristotele una visione 'naturalista' della virtù, ${ }^{1}$ per cui la virtù e il caratte-

1 Non verrà qui preso in considerazione il cosiddetto argomento dell'ergon, per cui la felicità corrisponderebbe alla realizzazione eccellente della funzione propria dell'essere umano, i.e. la razionalità. Tale

\section{Philosophica 4}

e-ISSN 2610-8925 | ISSN 2610-8933

ISBN [ebook] 978-88-6969-325-0 | ISBN [print] 978-88-6969-326-7 
re virtuoso di un agente siano determinati dalla natura stessa o da enti e relazioni causali appartenenti al mondo fisico e fisiologico ${ }^{2}$ (e a essi riducibili).

Tuttavia al fine di comprendere meglio l'affermazione di Aristotele, il presente articolo si suddividerà in due parti, volte a definire divergenze e similitudini tra il concetto di natura e il carattere, con riferimento anche al ruolo che le virtù naturali o il temperamento svolgono rispetto al carattere morale, in senso stretto.

Nella prima parte dunque verrà preso in considerazione il processo acquisitivo degli abiti mentre nella seconda ci si concentrerà su cosa accade all'agente una volta che gli stati abituali del carattere siano stati acquisiti.

In quest'ultima parte, inoltre, si argomenterà che l'esattezza determinativa della natura può trovare delle similitudini con il cosiddetto principio dell'unidirezionalità degli abiti ${ }^{3}$ e che dunque la nozione di natura e quella di carattere tendono, sotto questo aspetto, a convergere.

\section{Né per natura né contro natura: l'acquisizione della virtù}

Nel seguito del testo citato in apertura dell'articolo, Aristotele afferma che gli abiti e nello specifico le virtù non sono acquisite e non sorgono in noi né per natura né contro natura. ${ }^{4}$

funzione è 'per natura' in quanto corrisponde all'essenza dell'essere umano. In questo senso è spesso stata correlata al naturalismo. Sull'argomento si veda per esempio Lawrence 2006.

2 La questione di cosa si intenda con 'naturalismo' è molto complessa, data la presenza di diversi tipi di 'naturalismo' (ontologico, metodologico, etc...) e di diversi indirizzi (scientifico, liberalizzato). Intendo qui riferirmi a un'idea di naturalismo per cui fenomeni etici come la virtù possano essere esaminati e trattati a livello di 'fatti' naturali, nell'accezione proposta di meccanismi fisici e fisiologici. Sul naturalismo e i suoi vari indirizzi si veda De Caro 2013.

3 Uso qui i termini 'abito' e 'stato abituale' in modo sinonimico. L'abito (hexis) è una specie di qualità che si differenzia dalla disposizione (diathesis) per il fatto di essere più stabile e duraturo (Cat. 8, 8b 26-29): la virtù è quindi una qualità della parte appetitiva dell'anima. Per abitudine intendo il processo che porta alla formazione degli abiti: la ripetizione di azioni di una stessa qualità fa sì che un agente formi l'abito corrispondente alla qualità delle sue azioni. Tuttavia è anche vero che, una volta che tale abito sia stato acquisito, l'agente continuerà a compiere azioni di qualità coerente con il proprio abito: a partire dal coraggio, un agente compirà azioni coraggiose (e non, per esempio, vili).

4 Riguardo al ruolo che la natura svolge rispetto a vizio e virtù e acquisizione degli abiti, si veda anche Donini (1989, 100 ss.). Donini infatti afferma che, parlando di volontarietà di vizio e virtù, bisogna dar conto anche del ruolo della natura, che sembra minacciare la volontarietà del processo acquisitivo degli abiti. Sembra cioè, a suo avviso, che la natura costituisca un limite o un «crescendo di limitazioni» (Donini 1989, 102) alla tesi della volontarietà, sia in quanto la natura sembra determinare il fine sia in quanto le doti naturali sembrano indirizzare già il soggetto verso vizio o virtù. Inoltre Donini rileva che nell'Eth. Nic., a differenza dell'Eth. Eud., vi sia un ridimensiona- 
Per chiarire meglio questo punto bisognerà dunque brevemente considerare cosa Aristotele intenda con 'essere per natura' ed 'essere contro natura' in un altro dei suoi scritti etici, l'Etica Eudemia.

Definiamo quel che è per natura all'incirca con questi due elementi: con quel che fin dalla nascita a tutti si accompagna e con quel che in noi si forma se alla generazione è permesso di svilupparsi linearmente, come per esempio la canizie e la vecchiaia e le altre cose come questa. (Eth. Eud., II, 8 1224b 31-34; trad. it. Donini)

Ciò che è per natura viene dunque definito attraverso due criteri nell'Etica Eudemia:

1. è per natura ciò che è presente sin dal momento della nascita;

2. è per natura ciò che matura quando lo sviluppo non è ostacolato.

Il primo criterio implica nozioni quali il desiderio o l'essere bipede dell'uomo. Quest'ultima infatti è una caratteristica presente nell'uomo sin dalla nascita ed è un elemento che rientra nella definizione essenziale dell'essere umano in quanto animale bipede razionale.

Il secondo criterio riguarda invece potenzialità che sono presenti sin dalla nascita ma che maturano e si sviluppano se il processo non è ostacolato: rientrano in questo secondo criterio lo sviluppo della facoltà razionale - che Aristotele nega ai bambini - e la vecchiaia.

Un uomo svilupperà la ragione e invecchierà inevitabilmente e in modo necessario a meno che una causa violenta non intervenga a impedire il darsi naturale di tale processo.

mento del ruolo che la natura svolge in quanto fattore per la felicità: se infatti nell'Eth. Eud., la physis è subito nominata come fattore della felicità (e tale scelta di Aristotele è attribuita da Donini al retroterra più vicino alle posizioni platoniche dell'Eth. Eud.), nell'Eth. Nic., la 'natura' viene menzionata solo successivamente. Il ridimensionamento del ruolo della 'natura' nell'Eth. Nic., è motivato, ad avviso di Donini, dal fatto che, in quest'opera, viene dato un maggiore rilievo al ruolo di abitudine e insegnamento come fattori contribuenti all'esercizio della felicità e all'acquisizione della virtù. Abitudine e natura sembrano dunque essere viste dall'autore quasi come 'concorrenti' o 'antagoniste' rispetto all'acquisizione degli stati abituali. In particolare, Donini sostiene che le virtù naturali costituiscano uno dei maggiori elementi di criticità alla tesi del ruolo determinante che abitudine e insegnamento svolgono nell'acquisizione di vizio e virtù, proprio perché gettano un'ombra sull'affermazione che vizio e virtù dipendano dal soggetto (Donini 1989, 118). Tuttavia si cercherà di argomentare che riconoscere la presenza di virtù naturali, intese come inclinazioni naturali (più che come doti innate ed ereditarie), non implica necessariamente che il carattere di un agente sia da queste determinato nel senso di una necessità naturale. Inoltre, la natura, lungi dall'essere vista solo come 'concorrente' all'abitudine, può anche essere vista come una condizione base necessaria all'acquisizione della virtù, senza che questo faccia venir meno una divergenza fondamentale che differenzia i processi naturali dal processo acquisitivo degli stati abituali: mentre i processi naturali sono unidirezionali, il processo acquisitivo degli abiti può dar luogo a esiti contrari, i.e. vizio e virtù. 
La virtù e il vizio, invece, in quanto stati abituali del carattere, non sono per natura e non rientrano nella casistica né del primo né del secondo criterio, dal momento che essi non sono presenti in noi sin dal momento della nascita, come l'essere bipede, e non si svilupperanno necessariamente, come la razionalità o la vecchiaia.

Un uomo, dunque, non nasce virtuoso (o vizioso) né diverrà necessariamente virtuoso (o vizioso).

Tuttavia questo non implica che la virtù - o il vizio - siano contro natura:

Per esempio una pietra che per natura si muove verso il basso non prenderà l'abitudine di muoversi verso l'alto, neanche se qualcuno voglia abituarla lanciandola in alto migliaia di volte, né il fuoco prenderà l'abitudine di muoversi verso il basso, e nessun'altra cosa che è per natura in un certo modo potrà venire abituata a essere diversa. (Eth. Nic., II, 1 1103a 20-23)

L'esempio menzionato nell'Ethica Nicomachea è particolarmente informativo rispetto alla differenza fondamentale che intercorre tra stati abituali e ciò che è per natura, attraverso un'esemplificazione 'controfattuale' di un caso in cui qualcosa venga mosso contro natura.

La pietra tende infatti per natura a tornare verso il suo luogo proprio, che è il basso, e similmente il fuoco tende verso l'alto.

Come Aristotele afferma in Ph., VIII, 1 252a 17-19 il fuoco, che tende verso l'alto, tenderà sempre regolarmente verso l'alto, non qualche volta sì e qualche volta no.

La natura è cioè caratterizzata da una certa regolarità e costanza, a meno che non vi sia una ragione per questo cambiamento - la causa violenta o forzata che ne altera la regolarità.

La pietra, infatti, 'forzatamente', potrebbe essere scagliata verso l'alto: potrebbe cioè essere mossa contro il suo impulso interiore.

Tuttavia a ciò che è contro natura non si può essere in alcun modo abituati: si potrebbe lanciare una pietra verso l'alto migliaia di volte, eppure in nessun modo questa tenderà 'naturalmente' verso l'alto.

La virtù e il vizio dunque non sono neppure contro natura per due ragioni che sembrano emergere da queste prime considerazioni: innanzitutto, gli abiti vengono acquisiti attraverso la ripetizione di azioni e, in secondo luogo, gli abiti possono essere contrari tra loro. L'uomo può cioè divenire vizioso o virtuoso, mentre il fuoco non può tendere verso l'alto o verso il basso. Difetta dunque alla nozione di acquisizione degli abiti la necessità naturale.

Tuttavia Aristotele riconosce che la natura possa costituire una sorta di condizione necessaria per l'acquisizione della virtù morale e per il raggiungimento della felicità. 
E la felicità verrà a essere qualcosa di facilmente accessibile per molti, dato che potrà essere raggiunta sulla base di un qualche insegnamento o esercizio, da tutti quelli che non hanno qualche impedimento naturale a praticare la virtù. (Eth. Nic., I, 10 1099b 18-20)

La felicità viene qui detta essere accessibile a molti, non a tutti, e tale restrizione riguarda quelli che non sono incapacitati alla virtù da qualche impedimento naturale.

È possibile vedere in questa limitazione il celarsi delle doti naturali e interpretare dunque l'incapacità alla virtù come una sorta di danneggiamento delle disposizioni naturali (Donini 1989, 106). Tuttavia il riferimento alle 'disposizioni naturali' può essere duplicemente interpretato. Da un lato, in un senso forte, le disposizioni naturali andrebbero intese come doti innate ed ereditarie e, in questo caso, quanto Aristotele afferma sarebbe una delle prese di posizione più forti in merito al ruolo causale che la natura svolge nella formazione del carattere. ${ }^{5}$

Nel senso più debole, invece, le disposizioni naturali sarebbero qui comprese come una disponibilità naturale all'acquisizione della virtù e, come osservato da Alessandro di Afrodisia, una dotazione naturale ( $P$. Eth., 29, 158, 5-20). Tale dotazione non richiede che il soggetto nasca possedendo già la virtù ma che nasca con la capacità di acquisirla.

La natura sarebbe dunque semplicemente la condizione base necessaria per l'acquisizione della virtù che distingue l'uomo, l'unico in grado di acquisirla, dagli altri animali, in quanto l'uomo è dotato, per natura, della facoltà razionale. In questo senso la natura sarebbe sì uno dei fattori della virtù, in quanto fornirebbe una condizione necessaria alla sua acquisizione, ma non costituirebbe un elemento discriminatorio all'interno del genere umano (Eth. Eud., II, 61222b 16-20): servirebbe a distinguere non uomo da uomo, ma l'uomo dagli altri regni naturali (animali, piante).

Sembra che, proprio con il medesimo significato, Aristotele parli della natura nel libro II dell'Etica Nicomachea.

Quindi le virtù non si generano né per natura né contro natura, ma è nella nostra natura accoglierle, e sono portate a perfezione in noi per mezzo dell'abitudine. (Eth. Nic., II, 1 1103a 24-26)

5 Tuttavia questa interpretazione darebbe luogo a un'evidente incoerenza con quanto l'autore afferma in merito all'apprendimento e all'abitudine come i due soli fattori causali responsabili dell'acquisizione della virtù menzionati come strumenti per il raggiungimento della felicità a Eth. Nic., I, 10 1099b 18-20. 
Non essendo né per natura né contro natura, gli abiti possono essere acquisiti dal soggetto in quanto quest'ultimo è naturalmente atto a riceverli.

A partire da ciò è anche chiaro che nessuna virtù morale nasce in noi per natura, dato che nessun ente naturale si abitua a essere diverso. (Eth. Nic., II, 1 1103a 18-20)

La possibilità della 'diversità' o, per meglio dire, di esiti contrari, cui si fa riferimento, rappresenta dunque uno degli aspetti di divergenza tra natura e processo acquisitivo degli abiti.

Sebbene con due diversi aspetti qualitativi, la virtù e il vizio sono caratterizzati infatti dal medesimo processo acquisitivo, i.e. l'abitudine e la ripetizione di azioni della medesima qualità dello stato abituale che si acquisirà.

Se, cioè, un uomo può divenire coraggioso attraverso la ripetizione di azioni coraggiose, il medesimo uomo può divenire codardo (o temerario) attraverso la ripetizione di azioni codarde (o temerarie).

Virtù e vizio, essendo contrari tra loro e al contempo caratterizzati dal medesimo processo di acquisizione, sono anche de iure caratterizzati dalla stessa 'probabilità' di acquisizione.

Inoltre, ogni virtù si genera e si distrugge a partire e per mezzo delle stesse cose [...]. Se non fosse così, non si avrebbe bisogno per nulla di un maestro, ma tutti si genererebbero buoni o cattivi. [...] Infatti alcuni diventano moderati e miti, altri intemperanti e iracondi: i primi a partire dal tenere in quei casi un certo tipo di comportamento, i secondi a partire dal comportamento opposto. Allora, in una parola, gli stati abituali derivano da attività dello stesso tipo. (Eth. Nic., II, 1 1103b 7-22)

È qui evidente dunque in che modo questo aspetto diverga dalla nozione di ciò che è per natura: un uomo non è caratterizzato dalla stessa probabilità di invecchiare o tornare giovane. L'essere umano invecchia necessariamente e necessariamente sviluppa la capacità razionale.

Se la virtù fosse presente in noi per natura non potremmo formarci un abito contrario alla nostra natura, i.e. non si potrebbe divenire viziosi. Si sarebbe, al contrario, tutti buoni o tutti cattivi.

Questo implica che la disposizione all'acquisizione degli stati abituali è caratterizzata da una certa indeterminatezza o contingenza.

Mentre i processi naturali sono caratterizzati dalla necessità, l'uomo, in quanto principio d'azioni moralmente significative e qualitativamente definite, può dare luogo ad azioni di range qualitativo opposto.

Le azioni moralmente significative non sono caratterizzate dalla stessa necessità che caratterizza la generazione di un uomo a parti- 
re da un uomo e, più in generale, la generazione di un individuo della specie X a partire da e solo da un altro individuo della specie X. ${ }^{6}$

L'uomo è principio di opposti: può essere, de iure, principio e causa di azioni virtuose quanto viziose nello stesso modo e contingentemente.

Il fatto che l'uomo possa de iure divenire tanto virtuoso quanto vizioso, trova tuttavia una limitazione all'equa distribuzione di questa probabilità nelle circostanze attuali dello sviluppo del proprio carattere o dell'acquisizione dei propri stati abituali.

Aristotele è infatti disposto a riconoscere l'esistenza di 'virtù naturali' (ciò che forse oggi descriveremmo con 'temperamento' o 'indole') che determinano alcune delle caratteristiche con cui un individuo nasce.

Un individuo può cioè essere di indole irosa o coraggiosa e la natura della sua indole è determinata da caratteristiche fisiologiche e, nello specifico, dalla composizione del sangue.

Bisogna dunque pensare che il contributo della natura sia più 'determinante' rispetto a quanto visto finora?

Riconoscere il contributo di fattori fisiologici allo sviluppo della virtù morale non significa necessariamente doversi spingere verso un determinismo materiale (Viano 2007, 37).

Aristotele afferma infatti che:

Si deve indagare quali sono le cose verso cui noi siamo inclini, dato che persone diverse sono portate per natura a cose diverse. Questo risulterà chiaro dal piacere e dal dolore che nascono in noi. Dobbiamo spingerci nella direzione opposta, infatti allontanandoci molto dall'errore perverremmo al giusto mezzo, come fanno coloro che raddrizzano i legni storti. (Eth. Nic., II, 9 1109b 1-7)

La virtù naturale o le inclinazioni naturali, più che determinare il carattere morale di un agente, che può sempre spingersi verso la direzione opposta, possono piuttosto, come già detto, porre un limite a quell'equa distribuzione di probabilità di divenire virtuoso o vizioso di cui si è parlato.

Un uomo naturalmente tendente alla codardia sarà per Aristotele abituato con più difficoltà a essere coraggioso che non un uomo naturalmente tendente alla temerarietà (Eth. Nic., II, 8 1109a 1-5), in quanto vi sono estremi più lontani dal giusto mezzo che altri.

6 Leunissen $(2017,124)$ : «The character traits [...] are capacities that are distinct for the capacities that stones have to fall toward the center of the earth (or, for that matter, from the natural capacities all animals have for touch): while the latter are one-directional, the former are two-directional and, importantly, require 'desire or choice' for their realization (unlike stones, humans do not simply move or behave in the way they do by nature, but rather do so 'by desire and choice': our intentions matter)». 
Sebbene dunque de facto le probabilità di divenire virtuoso piuttosto che vizioso non siano le medesime, resta vero che il processo di formazione del carattere è aperto a esiti opposti e che, a differenza della causalità naturale che produce sempre un unico risultato, nel caso di vizio e virtù l'uomo può divenire virtuoso o vizioso. ${ }^{7}$

Ulteriore segno della contingenza di vizio e virtù e della loro non necessità rispetto al soggetto agente sono le pratiche sociali di lode e biasimo, dal momento che Aristotele afferma che vizio e virtù sono meritevoli di biasimo e lode e che, tuttavia, questi ultimi non possono essere legittimamente attribuiti a ciò che si genera per caso o per natura.

Non biasimeremmo un essere umano esteticamente brutto se la sua bruttezza derivasse dalla sua natura, cioè se fosse naturalmente conformato in quel modo (Eth. Nic., III, 7 1114a 21-25).

Il fatto che vizio e virtù siano oggetto delle pratiche di apprezzamento sociale è dunque un'ulteriore prova del fatto che il possesso di tali stati abituali e la loro stessa acquisizione non sia qualcosa di naturalmente determinato ma che, al contrario, lascia spazio alla contingenza. Dell'essere virtuoso o vizioso non è responsabile la natura ma il soggetto agente che tale è diventato. Lode e biasimo vengono infatti attribuiti alla causa del risultato considerato.

Il processo di acquisizione di vizio e virtù è dunque un processo aperto, a differenza dei processi naturali e tale processo acquisitivo dipende dall'uomo stesso, che ne è causa e principio.

Pur desiderando non invecchiare, infatti, questa possibilità non potrebbe mai dipendere dall'uomo poiché i processi naturali, come abbiamo visto, sono caratterizzati non solo dalla necessità ma anche dall'unilateralità (o unidirezionalità).

Con questo si intende che, nel caso di un processo naturale, all'uomo non è data la possibilità di $\mathrm{X}$ e non-X, invecchiare e non invecchiare. Tale processo può solo essere 'interrotto' o 'impedito' da una causa violenta ma rimarrà in ogni caso un processo unilaterale, in cui non sono disponibili al soggetto entrambe le alternative.

Nel caso dell'acquisizione di vizio e virtù invece, all'uomo sono aperte entrambe le alternative: l'uomo può cioè $\mathrm{X}$ e non-X, divenire virtuoso o divenire vizioso.

Si è dunque visto come Aristotele riconosca che la natura 'contribuisce' alla virtù in due modi: da un lato la natura offre la condizione base necessaria perché la virtù possa svilupparsi (la razionalità e la disposizione dell'uomo a ricevere vizio e virtù, in quanto natural-

7 Oltre alle inclinazioni naturali anche il contesto in cui un soggetto cresce e viene educato influenza evidentemente le probabilità di un agente di divenire virtuoso o vizioso (Destrée 2011). Il nascere e l'essere educato da un buon maestro o in una buona famiglia sono fattori che contribuiscono in modo decisivo alla 'redistribuzione' delle probabilità, come lo stesso Aristotele afferma in Eth. Nic., II, 1 1103b 23-25. 
mente atto a riceverli); dall'altro, attraverso il riconoscimento dell'esistenza di disposizioni naturali, si è visto che queste possono avvicinare o allontanare il soggetto dal giusto mezzo.

Tuttavia, nonostante il riconoscimento di questo contributo, in questa prima sezione, sono state messe in luce alcune delle più significative divergenze tra virtù e natura: mentre quest'ultima è infatti caratterizzata da processi unidirezionali che non lasciano spazio a esiti contrari, l'acquisizione di stati abituali del carattere lascia aperta la possibilità di realizzazione di due esiti tra loro contrari, vizio e virtù.

\section{La necessità dei processi naturali e la 'necessità qualitativa' delle azioni}

La divergenza tra processi naturali e virtù morali sembra ridimensionarsi quando si considera il soggetto agente in quanto già possessore di stati abituali del carattere stabili, il che ci conduce alla seconda parte dell'argomentazione.

Si è detto che gli stati abituali vengono acquisiti attraverso la ripetizione di azioni caratterizzate dal medesimo aspetto qualitativo, i.e. si diviene generosi compiendo azioni generose, e si è detto anche che inizialmente questo processo è aperto a esiti contrari.

Inoltre, dipendendo dal soggetto il corso d'azione da intraprendere (essendo cioè in lui il principio e dunque la causa di tale corso d'azione) questo processo risulta volontario.

Tuttavia Aristotele in Eth. Nic., III, 7 afferma che l'agente non è padrone nello stesso modo delle azioni e degli stati abituali.

Invece non sono volontari allo stesso modo le azioni e gli stati abituali: noi siamo padroni delle nostre azioni dal principio fino alla fine, se conosciamo le condizioni particolari dell'agire; per gli stati abituali siamo padroni del loro inizio, ma ciò che si aggiunge in ogni singolo caso non ci è noto, come avviene anche nel caso delle malattie. (Eth. Nic., III, 7 1114b 30-1115a 4)

È possibile qui distinguere i due elementi, oggetto dell'analisi:

- le azioni;

- gli stati abituali.

Per quanto riguarda le prime, l'agente è padrone o in controllo dell'azione dal suo principio sino alla sua fine. Questo significa, per esempio, che se il soggetto ha deliberato e scelto di prestare dei soldi a un amico in difficoltà e se questa azione richiede una serie di azioni intermedie, il soggetto è padrone della sua azione dall'inizio fino alla fine, cioè finché l'azione non verrà portata a termine. L'azione potrà dunque essere interrotta o modificata nel suo corso in qualun- 
que momento, in quanto il soggetto resta in controllo dell'occorrere della propria azione dal principio sino alla fine.

Tuttavia Aristotele ci avvisa che lo stesso non può essere detto degli stati abituali perché di questi non siamo in controllo sino alla fine.

Il breve paragone che viene qui istituito è quello con la malattia.

Il soggetto potrebbe essere detto in controllo del 'principio' della malattia: dipendeva da lui, per esempio, coprirsi in vista del clima più rigido ma, una volta che la malattia si sia manifestata, il soggetto non è più padrone del suo svolgersi e progredire.

Nel caso degli stati abituali accade qualcosa di analogo: era in potere dell'agente agire in un determinato modo, coraggiosamente o vilmente, ma una volta che lo stesso abbia acquisito un certo stato abituale (il coraggio o la codardia) non è più in controllo della qualità delle sue azioni.

Le due affermazioni sembrerebbero apparentemente in contraddizione eppure, a uno sguardo più attento, notiamo che la capacità del soggetto di essere in controllo delle sue azioni è conciliabile con quanto si afferma in merito al non essere parimenti padroni dei propri stati abituali.

L'agente può dunque controllare la sua azione dal principio alla fine ma non può controllarne allo stesso modo la caratterizzazione qualitativa, viziosa o virtuosa.

Un uomo coraggioso, a partire dal coraggio, non compirà azioni codarde; ciò concretamente vuol dire che un uomo coraggioso agirà coraggiosamente.

Questo non implica l'inutilità del processo deliberativo. L'agente si troverà ancora nella necessità di deliberare quale corso d'azione sia migliore tra le alternative che gli si presentano in quelle date circostanze, ma non si troverà a dover scegliere tra vizio e virtù, poiché agirà sempre nel senso coerente con il suo abito etico. L'incertezza non riguarda tanto la qualificazione morale del mezzo scelto, quanto più la correttezza e l'appropriatezza dello stesso nelle circostanze particolari.

Il soggetto che si trova ad agire dovrà comunque considerare le circostanze particolari di un'azione, quale sia il corso d'azione migliore da intraprendere in una determinata circostanza, acquisire le informazioni rispetto alle circostanze particolari stesse che rappresentano il contesto dell'azione stessa.

Sarà, in questo senso, padrone della sua azione dall'inizio sino alla fine.

D'altronde, se così non fosse, il processo deliberativo non potrebbe avere luogo, poiché condizione della deliberazione e della scelta è che l'agente abbia a disposizione almeno due opzioni alternative tra cui scegliere, sebbene queste rientrino all'interno della stessa qualificazione etica.

Questa è la strategia interpretativa adottata da Alessandro d'Afrodisia che, volendo rivendicare alla concezione etica di Aristotele la libertà di scelta da parte del soggetto, teorizzava questa libertà 
nei termini di scelta tra più opzioni, tra loro opposte, ’́ $\nu \tau \iota k \varepsilon i ́ \mu \varepsilon \nu \alpha, \mathrm{e}$ non contrarie, દ̇vavtía. (Alex. Aphr. De Fato 180, 13-181, 6).

Tuttavia ciò su cui l'agente non delibererà è la qualità dell'azione stessa: l'agente non considererà come alternative d'azione a lui disponibili corsi d'azione caratterizzati da un range qualitativo opposto, per esempio la codardia per un uomo coraggioso.

Tali corsi d'azione non potranno essere oggetto di una seria considerazione da parte del soggetto perché lo stato abituale, una volta acquisito, è caratterizzato da una certa 'unidirezionalità'. ${ }^{8} \mathrm{Con}$ ciò si intende che gli stati abituali aprono solo a corsi d'azione del medesimo range qualitativo dello stato abituale posseduto dall'agente.

Il possesso stabile degli stati abituali conduce all'esclusione dei contrari, vizio e virtù, che invece, in prima istanza, erano stati considerati come un'opzione disponibile all'agente.

Nel passaggio dunque dal processo acquisitivo degli abiti al loro possesso, si delinea una chiusura di quella apertura alla contrarietà che era stata assunta inizialmente come elemento di divergenza tra la natura e l'acquisizione degli abiti.

Aristotele ribadisce qui che l'acquisizione degli stati abituali è tuttavia essa stessa un processo volontario, prevedendo forse una possibile obiezione: se gli stati abituali non venissero acquisiti volontariamente e se la qualità di un'azione che da essi deriva è necessariamente fissata dal principio dell'unidirezionalità, la virtù e il vizio di un'azione potrebbero essere considerati a loro volta involontari. Inoltre, se degli stati abituali siamo padroni del loro principio ma non della loro fine, in che modo dovremmo intenderne la volontarietà? ${ }^{9}$

Aristotele istituisce qui nuovamente un'analogia con la malattia e la salute.

8 In particolare, rispetto a questo tema, si vedano Donini 2014 e Donini 1989. Inoltre si veda anche Bobzien 2011.

9 Per una diversa posizione si veda Destrée 2011. Destrée argomenta a favore del riconoscimento di uno scarto qualitativo tra azioni compiute katà logon e azioni compiute metà logou. Le prime sono quelle tipiche dei bambini che non agiscono con ragione ma secondo ragione, i.e. la ragione di un altro, il maestro o, in generale, l'educatore. Le seconde sono invece le azioni compiute da un essere umano giunto a piena maturazione della propria facoltà razionale e che dunque agisce con ragione. Destrée argomenta che tra i due momenti vi debba uno scarto o uno 'spazio di libertà' in cui l'agente può scegliere se accogliere o rifiutare la propria educazione, pena l'involontarietà degli stati abituali. Se infatti il bambino è stato educato a essere vizioso può essere egli riconosciuto come responsabile dei propri abiti? Questa interpretazione, seppur suggestiva, non trova però alcuna teorizzazione sistematica in Ethica Nicomachea e si basa solamente sullo scarto semantico tra katà logon e metà logou. D’altronde Aristotele in Ethica Nicomachea ritiene che affinché un'azione, o una serie di azioni, siano considerate volontarie e l'agente responsabile è sufficiente che l'agente contribuisca in qualche modo all'azione e questo criterio è rispettato nel caso dell'educazione. 
All'inizio vi era per lui la possibilità di non ammalarsi, ma quando si è lasciato andare ciò non è più possibile, come non è possibile per chi ha lasciato cadere una pietra riprenderla di nuovo, eppure dipendeva da lui raccoglierla e scagliarla, dato che il principio è in lui. Così anche per l'ingiusto e l'intemperante vi era all'inizio la possibilità di non diventare persone di quel tipo - e per questo lo sono volontariamente - ma quando lo sono diventati non hanno più la possibilità di non esserlo. (Eth. Nic., III, 7 1114a 16-21)

Era aperta al soggetto la possibilità di non ammalarsi ma una volta che si sia ammalato, una volta cioè che $\mathrm{X}$ e non non- $\mathrm{X}$, non-X non dipende più da lui.

L'acquisizione di uno stato abituale piuttosto che un altro è dunque sempre un processo volontario, proprio in virtù della considerazione della diversità del rapporto causale che abbiamo stabilito esserci tra la necessità naturale e l'apertura alla contrarietà tipica dell'acquisizione di vizio e virtù. ${ }^{10}$

L'unidirezionalità degli abiti ci induce invece a considerare come tra la necessità del processo naturale e la necessità qualitativa delle azioni che derivano dagli abiti stessi, vi sia una convergenza.

Nel caso di un processo naturale si era visto come qualora il soggetto possa $\mathrm{X}$, allora il soggetto non può non-X, i.e. se il fuoco può andare verso l'alto, allora il fuoco non può andare verso il basso (a meno che non intervenga una causa violenta).

Mentre in prima istanza si era sottolineato come non si potesse dire altrettanto dell'acquisizione della virtù, dal momento che il soggetto può $\mathrm{X}$ e anche non-X, divenire virtuoso e divenire vizioso, ora invece la causalità che è oggetto di considerazione a partire dal possesso stabile di stati del carattere, si avvicina più a una causalità del primo tipo che non del secondo.

Ora che il soggetto possiede lo stato abituale del coraggio, non potrà $\mathrm{X}$ e non-X ma solo $\mathrm{X}$, cioè non potrà agire coraggiosamente e vilmente ma potrà solo agire coraggiosamente.

Un comandante coraggioso potrebbe considerare vari corsi d'azione o varie strategie per affrontare il nemico sul campo di battaglia e tutte queste alternative potrebbero essere chiamate coraggiose. Ciò che non considererà sarà invece per esempio la ritirata o la fuga nel momento dell'azione militare.

10 Anche ammettendo che il principio dell'unidirezionalità degli abiti così formulato trasformi il carattere in una sorta di gabbia, bisogna notare che in ogni caso Aristotele considera questa gabbia volontaria, poiché volontariamente acquisita tramite la ripetizione di azioni e assuefazione. Pur ponendoci nel caso di un agente con un carattere ormai formato, sarebbe comunque possibile parlare di volontarietà delle azioni. Non solo perché il processo acquisitivo è stato volontario ma anche perché le azioni che ne derivano sono altrettanto volontarie. 
Tuttavia potremmo anche immaginare un comandante codardo che però deliberi di intraprendere un'azione militare contro il nemico, apparentemente coraggiosa, che sia invece guidata da altre 'motivazioni'.

Potremmo immaginare che questo comandante codardo sia guidato dal timore di essere punito o dal desiderio di onori e riconoscimenti.

Ora è chiaro che per Aristotele questa azione non sarebbe in ogni caso annoverata come coraggiosa perché, per compiere un'azione davvero virtuosa, c’è bisogno anche che la stessa sia accompagnata dalla giusta disposizione emotiva; tuttavia, a uno spettatore terzo, l'azione potrebbe apparire tale, cioè virtuosa e, nello specifico, coraggiosa.

Per questo, secondo Aristotele, gli stati abituali sono 'svelati' e 'rivelati' maggiormente laddove il tempo per un calcolo costi-benefici non ha modo di svolgersi. L'azione che ne discende sarà necessariamente rivelatrice dello stato abituale dell'agente (Eth. Nic., III, 11 1117a 17-22).

Sebbene Aristotele in linea di principio possa ammettere che vi sia uno spazio per la riconsiderazione della propria condotta (Eth. Nic., VII, 8 1150b 29 ss.), il processo di cambiamento degli abiti è considerato talmente improbabile che potrebbe essere definito come una possibilità de iure ma non de facto (Eth. Nic., I, 11 1100b 12-22).

L'acquisizione di un abito infatti è determinata dalla ripetizione di azioni del medesimo range qualitativo e, d'altronde, una volta che l'abito sia stato acquisito, da questo discendono azioni del medesimo range qualitativo dell'abito posseduto.

Perché un codardo dunque diventi coraggioso sarebbe necessario che questi inizi ad agire coraggiosamente in modo ripetuto al punto da acquisire l'abito contrario a quello che possiede.

E tuttavia, il principio dell'unidirezionalità degli abiti impedisce specificatamente che tale uomo codardo possa compiere azioni del range qualitativo opposto, cioè coraggiose.

D’altronde, come si è detto, corsi d'azione coraggiosi non occorreranno nemmeno come oggetto di deliberazione alla mente dell'agente codardo, non più che a una persona mite occorra in mente il ricorso alla violenza o all'omicidio come possibile soluzione di una disputa.

Questo implica di conseguenza una sorta di impossibilità de facto da parte dell'agente di cambiare il proprio stato abituale. Per questo l'abito diviene quasi come una natura (Eth. Nic., VII, 11 1152a 31) e altrettanto difficile da modificare.

La resistenza al cambiamento e l'esattezza nel determinare il range qualitativo dell'azione rendono dunque possibile un'assimilazione degli abiti alla natura stessa e nello specifico al tipo di causalità che è implicata nella nozione di natura. L'abitudine infatti sembra produrre un accidente durevole di un essere naturale. 


\section{Conclusioni}

Nella prima parte, ci si è soffermati sulle divergenze che contraddistinguono la nozione di natura e la virtù. Nello specifico si è mostrato che la natura, nonostante si caratterizzi come la condizione base necessaria per l'acquisizione della virtù, non determina la qualità morale di un agente. Nonostante inoltre sia possibile riconoscere un contributo delle 'doti naturali' o delle 'virtù naturali' rispetto alla formazione del carattere, tale riconoscimento non è ancora sufficiente a determinare il carattere morale di un agente.

In questo senso si è inteso che le virtù naturali possono dunque 'avvicinare' o 'allontanare' un soggetto agente, maggiormente 0 in misura minore, dal giusto mezzo, ma esse, non essendo ancora virtù in senso proprio, possono essere sempre reindirizzate e il soggetto può essere 'raddrizzato' come si fa con un legno storto.

In breve, il carattere virtuoso o vizioso di un agente non è determinato dalla natura, né dalla natura comune, che egli condivide con tutti gli altri esseri umani (e che offre invece le condizioni per l'acquisizione della virtù) né dalla propria, che, al massimo, avvicina o allontana dalla virtù in senso proprio.

Tuttavia la divergenza che era stata istituita come una delle differenze su cui basare il discrimine tra natura e carattere, i.e. la possibilità di contrari, viene ridimensionata laddove si consideri il soggetto come già in possesso di stati abituali del carattere. Gli stati abituali implicano cioè non solo una certa regolarità qualitativa delle azioni (che sembra in alcuni sensi avvicinarsi alla regolarità della natura) ma anche una chiusura di quella possibilità dei contrari che era prima stata assunta come elemento distintivo tra natura e virtù.

In questo senso, dunque, il carattere di un agente può essere assimilato a una sorta di 'natura', sebbene il rapporto tra natura e virtù, come si è cercato di mostrare, sia caratterizzato da elementi di convergenza tanto quanto da elementi, imprescindibili, di divergenza.

\section{Abbreviazioni}

$\begin{array}{ll}\text { Eth. Nic. } & \text { Etica Nicomachea } \\ \text { Eth. Eud. } & \text { Etica Eudemia } \\ \text { De Fato } & \text { On Fate } \\ \text { Cat. } & \text { Le Categorie } \\ \text { P. Eth. } & \text { Ethical Problems } \\ \text { Ph. } & \text { Fisica }\end{array}$




\section{Bibliografia}

Barnes, Jonathan (ed.) (1984). Nicomachean Ethics. Vol. 30 of The Complete Works of Aristotle. Princeton: Princeton University Press.

Bobzien, Susanne (2011). "Choice and Moral Responsibility in Aristotle's Nicomachean Ethics (III 1-5)». Polansky, Ronald (ed.), The Cambridge Companion to Aristotle's Nicomachean Ethics. New York: Cambridge University Press, 81-109.

Broadie, Sarah (1991). Ethics with Aristotle. Oxford: Oxford University Press.

Dalimier, Catherine (trad.) (2013). Aristotele: Ethique à Eudeme. Paris: Flammarion.

De Caro, Mario (2013). «Naturalismo scientifico e naturalismo liberalizzato». Summa, Michela; Giuffrida, Pietro (eds), Naturalism and Subjectivity. Metodo. International Studies in Phenomenology and Philosophy, 1(2), 27-37.

Destrée, Pierre (2011). «Aristotle's on Responsibility for One's Character». Pakaluk, Michael; Pearson, Giles (eds), Moral Psychology and Human Action in Aristotle. Oxford: Oxford University Press, 285-319.

Donini, Pierluigi (1989). Ethos: Aristotele e il Determinismo. Alessandria: Edizioni dell'Orso.

Donini, Pierluigi (trad. e note a cura di) (1999). Aristotele: Etica Eudemia. RomaBari: Laterza.

Donini, Pierluigi (2014). Abitudine e Saggezza. Alessandria: Edizioni dell'Orso. Inwood, Brad; Woolf, Raphael (transl. and ed. by) (2013). Aristotele: Eudemian Ethics. New York: Cambridge University Press.

Lawrence, Gavin (2006). «Human Good and Human Function». Kraut, Richard (ed.), The Blackwell Guide to Aristotle's Nicomachean Ethics. Malden (MA); Oxford: Blackwell Publishing, 37-75.

Lennox, James (2015). «Aristotle on the Biological Roots of Virtue: the Natural History of Natural Virtue». Henry, Devin; Nielsen, Karen Margrethe (eds), Bridging the Gap between Aristotle's Science and Ethics. Cambridge: Cambridge University Press, 193-213.

Leunissen, Mariska (2017). From Natural Character to Moral Virtue in Aristotle. Oxford: Oxford University Press.

Natali, Carlo (trad. e note) (1999). Aristotele: Etica Nicomachea. Roma-Bari: Laterza.

Radice, Roberto (a cura di) (2011). Aristotele: Fisica. Milano: Bompiani.

Sharples, Robert (transl. by) (1983). Alexander of Aphrodisias: On Fate. London: Duckworth.

Sharples, Robert (transl.) (1990). Alexander of Aphrodisias: Ethical Problems. London; New York: Bloomsbury.

Viano, Cristina (2007). «Aristotle and The Starting Point of Moral Development: The Notion of Natural Virtue». Stern-Gillet, Suzanne; Corrigan, Kevin (eds), Aristotle and Neoplatonism. Essays in Honor of Denis O'Brien. Vol. 2 of Reading Ancient Texts. Leiden: Brill, 23-42.

Woods, Michael (transl. and commentary by) (2005). Aristotele: Eudemian Ethics - Book I, II, VIII. Oxford: Clarendon Press.

Zanatta, Marcello (a cura di) (2007). Aristotele: Le Categorie. Milano: BUR. 



\title{
Fear as a Destructive Pain Human Nature and Violent Affections in the Eudemian Ethics of Aristotle
}

\author{
Gaia Bagnati \\ Università Ca’ Foscari Venezia, Italia
}

\begin{abstract}
In the discussion on bravery in Eth. Eud., III, 1 Aristotle determines the objects that are absolutely dreadful by means of an explicit reference to 'human nature'. This reference has not received much consideration from scholars in the field. The present paper argues that the reference under discussion entails a notion of 'human nature' that corresponds to a human being's psychological disposition to endure fearful emotions - that is to say, painful emotions that imply the representation of a pain capable of destroying a human being - up to a certain degree of intensity. Furthermore, this article claims that the same notion of 'human nature' is implied in Eth. Eud., II, 8 in the discussion of involuntariness concerning the cases of mixed actions where Aristotle refers to the 'nature' of the agent as a criterion to determine the involuntariness of an action.
\end{abstract}

Keywords Aristotle. Human nature. Sou. Disposition. Fear. Sensible affections. Physical pains.

Summary 1 Introduction. - 1.1 Human Nature as a Criterion for Determining Fearful Objects. - 1.2 Human Nature as a Capacity of a Human Being to Feel Fearful Affections. - 2 Human Nature as a Disposition of the Soul to Endure the Perception of a Destructive Pain. -3 Human Nature as a Criterion for the Determination of the Voluntariness in the Cases of Mixed Actions. -4 Conclusion. 
Aristotle's ethics may be characterized as 'naturalistic' in the sense that they assign to nature an explicative and evaluative role. ${ }^{1}$ Having in mind this definition, the most representative thesis of Aristotle's ethical naturalism may be identified by the famous definition of happiness as an "activity of the soul in accordance with virtue" (Eth. Nic., I, 6, 1098a 7; Ross 1984). ${ }^{2}$ This definition in Nicomachean Ethics I, 6 is the result of an argument in which the natural function (ergon) of the human being is identified with the activity of the rational soul. Various scholars have argued that the 'ergon argument' is based on a fundamental principle of Aristotle's metaphysics: the principle according to which in natural substances 'nature' corresponds to the essence and to the end; that for the sake of which the process of generation takes place. ${ }^{3}$

The definition of happiness of Eudemian Ethics (Eth. Eud.), concerning the idea that happiness is an activity of the soul in accordance with virtue, does not present relevant differences with regard to Eth. Nic.; however it does not contain the reference to human nature. In any case, the idea that the reason of a human being corresponds to a 'nature' is unequivocally stated in other points of Eth. Eud. ${ }^{4}$

In this paper I will not address the acknowledged Aristotelian acceptation of 'human nature' as a rational principle. I will instead attempt to show that in some passages of Eth. Eud. - the discussion on bravery in III, 1 and the discussion on the involuntary in II, 8 - Aristotle uses another notion of 'human nature': a notion which concerns the sensible affections and serves as a criterion for the ethical evaluation in certain circumstances.

1 Miller (1995, 27). I am really thankful to Cristina Viano and Carlo Natali for the challenging discussions and sharp comments on this paper. I thank the audience of the Venice workshop (especially Pierre-Marie Morel and Francesco Binotto) and I show deep gratitude to Iain MacPherson for the careful linguistic revision without which this English version would not have been possible. This English version of the paper has also benefited from its presentation at the 5th FINO (Consorzio di Dottorato in Filosofia Nord-Ovest) Graduate Conference held in Pavia in September 2018.

2 The definition of happiness of Eth. Eud., is formulated in a slightly different way: it is the "activity of a perfect life according to a perfect virtue" (Eth. Eud., II, 1, 1219a 38-39; Rackham 1981).

3 See Natali 1989, Miller 1995, Annas 1996 and Irwin 2007. A non-naturalistic interpretation of the ergon argument, that is a reading according to which the notion of 'nature' in Eth. Nic., I, 6 does not have an ontological relevance, is defended for example by Ackrill (1974), Destrée (2002), Murgier (2013).

4 "The spirit as a whole both in the uncontrolled and in the self-controlled man acts voluntarily, and in neither case does the man act under compulsion, but one of the parts in them so acts - for we possess by nature both parts; since rational principle is a natural property [...] and also desire is natural [...]. Therefore, each of the two persons in a way acts not in accordance with nature, but absolutely each does act according to nature, though not according to the same nature" (Eth. Eud., II, 8, 1224b 25-1225a 1). 
In more detail: (1.1) I will argue that the mention of 'human nature' presented in Eth. Eud., III, 1 (1228b 24-26), in the discussion on the objects 'absolutely' fearful, entails a notion of human nature which is determined as a psychological limit of endurance regarding fear; (1.2) I will remark that fear is an affection involving a representation of a physical psychological pain which is destructive for a human being, accompanied by a pain of the same kind; (2) taking as a piece of evidence another passage of III, 1 (1229b 13-21), I will argue that an aspect of human nature may be more precisely defined as a disposition of the human soul to forbear fearful emotions up to a certain limit; (3) I will show that the notion of human nature mentioned in Eth. Eud., III, 1 appears also in the section of Eth. Eud., II, 8 on involuntariness in the cases of mixed action; (4) and finally I will draw some concluding remarks on the ethical implications of the Aristotelian characterization of human nature as related to pains that undermine the physical integrity of a human being.

\subsection{Human Nature as a Criterion for Determining Fearful Objects}

In the Eudemian Ethics there is one explicit reference to 'human nature'. In III, 1, 1228b 24-26, in the discussion on bravery, 'human nature' is referred to as a criterion for the discernment of objects that are absolutely fearful. ${ }^{5}$ As far as I can see, this reference has not received much consideration from scholars in the field of Aristotelian studies. ${ }^{6}$ In my opinion it deserves more attention since it introduces a notion of human nature conceived of as a psychological limit of endurance regarding fear.

The passage of Eth. Eud., III, 1 which contains the reference at issue constitutes the solution of an aporia presented at the beginning of the discussion of bravery. The aporia concerns the behaviour of

5 Even though the full expression ('human nature') is missing, the word 'nature' is used in some other passages of Eth. Eud. to denote the nature of a person or, seemingly, of human beings. See II, 8, 1225a 18-19, 1225a 20-24, 1225a 25-26, on the 'voluntary' and 'involuntary'; II, 3, 1221a 19-22, on temperance and the opposite vices of profligacy and insensitiveness; and II, 5, 1222a 36-38 on the determination of virtue as a middle state. I will consider the occurrences of 'nature' in II, 8 later on.

6 I am here in particular referring to the major twentieth and twenty-first century commentaries on the Eudemian Ethics: for example Dirlmeier 1962, Décarie 1978, Donini 1999, Kenny 2011, Wood 2013 and Inwood 2013 where I did not find any specific comment regarding the expression 'human nature' in the passage under discussion (III, 1 , $1228 \mathrm{~b} 24-26)$, nor any attempt to grasp its meaning. A greater interest among scholars has been generated by the reference to the 'nature' of the agent in the discussion on the involuntary of Eth. Eud., II, 8. On this point see for example Lefebvre (forthcoming) and Charles (2012); I will discuss this issue later on in the text. A more general analysis, devoted to the notion of 'nature' in the so-called 'common' books (that is Eth. Nic. V-VII), is provided by Donini (2014). 
the courageous person: more particularly the link between the courageous person's emotional reaction and the entity of the fearful event to which he reacts. The structure of the aporia may be reconstructed as follows:

A) Aristotle enumerates some opinions of other people on the brave person and the coward. These opinions emphasize an asymmetry between the intensity of the emotional reaction of both the brave person and the coward - and the dimension of the frightful event. It is believed that:

(1.1) The courageous person is fearless; (1.1.1) Or fears only slightly things of great magnitude;

(1.2) The courageous person endures things very fearful;

(2.1) The coward is prone to fear; (2.1.1) And fears everything, and intensely so;

(2.2) The coward does not endure anything, even things that are only slightly fearful. (italics added)

B) Aristotle develops dialectically the implications of the cited opinions in order to refute them. Commenting on the opinion (1.2) - "the courageous person endures things very fearful" he asks what are the things the courageous person endures: things that are fearful to somebody else or fearful to himself? If the brave person endured the things that were fearful to somebody else, his behaviour would not be remarkable (in fact, facing those things fearful to somebody else he would not test himself). If he endured the things that were fearful to himself, what would be fearful to him - Aristotle states would be many things of great magnitude (Eth. Eud., III, 1, 1228b 11-13). The opinion (1.2), indeed, established that the courageous person endured things highly fearful; but:

fearful things are productive of fear in the particular person to whom they are fearful - that is, if they are very fearful, the fear they produce will be violent, if slightly fearful, it will be weak; so it follows that the brave person's fears are great and many. (Eth. Eud., III, 1, 1228b 12-15; transl. Rackham 1981)

Following the reasoning quoted above, the courageous person seems to be someone who feels multiple and significant fears. But this goes against the opinions (1.1) and (1.1.1) which established that the brave person was fearless or had only slight fears regarding few objects (extremely fearful things). From here arises the unsolvable question: does the courageous person not fear anything, or a few things and slightly, or does he feel multiple and significant fears? 
The claim that I underlined with the quotation "fearful things are productive of fear in the particular person to whom they are fearful" ${ }^{\prime 7}$ seems like a tongue-twister but has a theoretically relevant content: it summarizes a conception of fear that I will call 'intentional', a conception that - as we will see - Aristotle will draw on in his solution with some fundamental specifications. According to the conception in question, a fearful object produces fear in a person that feels it; which means that the fearful object is always fearful to somebody. ${ }^{8} \mathrm{~A}$ further implicit claim of the mentioned view is that the fearful impression is connoted by a certain degree of intensity, in reason of which the object might be said to be fearful to a certain degree. The conjunction of the two conditions (the fact that fear produced by an object is: 1 . always produced in a certain subject; and 2. characterized by a certain degree of intensity) entails that the intensity of fear produced by an object is always provoked in a subject, and thus shows itself in the emotional reaction of the person in which the impression is produced. As a consequence, according to the view in question, a very fearful object produces strong fearful impressions in a subject, whilst a slightly fearful object produces weak impressions in him. ${ }^{9}$

Aristotle's solution to the aporia (if the courageous person does not fear anything, or a few things and slightly, or instead feels multiple and significant fears) consists in the distinction of two meanings of 'fearful': fearful 'absolutely' and fearful 'to a particular person'. The text is the following:

But perhaps 'fearful' is an ambiguous term, like 'pleasant' and 'good'. Some things are pleasant and good absolutely, whereas others are so to a particular person but absolutely are not so, but on the contrary are bad and unpleasant - all the things that are beneficial for the base, and all those that are pleasant to children qua children. And similarly, some things are fearful absolutely and

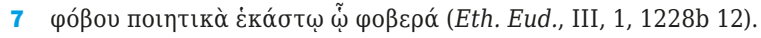

8 With the word 'intentional' I am not referring to a phenomenological concept; I refer, instead, to the idea according to which an object is always fearful to somebody. Furthermore, I suggest that this idea sheds light on a necessary condition of the fearful phenomenon, that is on the fact that the fearful occurrence is necessarily subjected to a subjective representation of something as fearful. Exposing such an idea, in my opinion, Aristotle assumes the perspective of a phenomenological analysis of fear in the sense that he focuses on fear qua phenomenon.

9 The view introduced in Eth. Eud., III, 1, 1228b 12-13 consists of the idea that the intensity of fear provoked by an object depends, at least to a certain extent, on the subject who feels the emotion. This dependence concerns the fact that fear necessarily manifests itself through an inner representation of the object in the subject. The emotional reaction of the subject therefore - at a phenomenal level of analysis - is the measure of the intensity of fear produced by an object, that is the capability of the object to produce fear. 
others to a particular person: thus the things that the coward qua coward fears are some of them not fearful to anybody and others only slightly fearful, but things that are fearful to most people, and all that are fearful to human nature, we pronounce to be fearful absolutely. But the brave person is fearless in regard to them, and endures fearful things of this sort, which are fearful to him in one way but in another way are not - they are fearful to him qua human being, but qua brave not fearful except slightly, or not at all. Yet such things really are fearful, for they are fearful to most people. (Eth. Eud., III, 1, 1228b 17-30) ${ }^{10}$

\subsection{Human Nature as a Capacity of a Human Being to Feel Fearful Affections}

The things that the coward fears are not fearful absolutely, but fearful to him; for most people they are not fearful, or only slightly so. The things that are fearful to most people and to human nature, on the contrary, are absolutely fearful.

Compared to the intentional conception of fear exposed a few lines before (the view according to which the fearful event entails a representation of an object as fearful to a subject), Aristotle's own conception presents an important specification, or rather a correction: (1) the representation is not always faithful to the reality in question, which implies that (2) the reality is the point of reference for the adequacy of the representation. ${ }^{11}$ The representation varies according to the subject; more particularly it depends both on the character of the singular individual and on some characteristics of human nature. To this point I shall return in a moment.

To define the objects objectively fearful, Aristotle is not content with a statistical argument; he does not only claim that the objects objectively fearful are those that appear fearful to most people. He mentions also: "all [the things] that are fearful to human nature"

10 In the cited passage the analogy with the 'good' is used to explain and solve the semantic ambiguity of the term 'fearful'. A comparison between the dialectical analysis of the two notions shows an interesting difference in the Aristotelian solutions. According to Aristotle what is good absolutely (that is good in the true sense) is good for the spoudaios, the virtuous man; what is 'fearful' absolutely, on the contrary, is fearful to most people. In the case of goodness, then, the criterion is the behaviour of a human being who constitutes an exception compared to the average person; in the case of fearfulness, instead, the criterion is the behaviour of the average person.

11 If the intentional conception of fear presented in Eth. Eud., III, 1, 1228b 12-13 corresponds to an analysis of fear qua phenomenon, the Aristotelian conception integrates the results of such an analysis (the idea according to which the fearful emotion necessarily entails a subjective representation of the object as fearful) in a wider conception, whose aim is to define what it is that, in itself, is a fearful reality. 
(Eth. Eud., III, 1, 1228b 25). ${ }^{12}$ It seems to me that this remark, placed beside the data concerning the majority of people, involves a deeper level of analysis; it goes beyond the quantitative observation of different cases and designates an intrinsic structure of things. The mention of human nature, therefore, in my opinion entails an ontological conception of human nature pertinent to the context of argumentation that requires its use, namely the examination of fearful objects.

First of all, I think that the expression 'human nature' in Eth. Eud., III, 1, 1228b 25 stands for a universal characteristic, a characteristic that concerns all people as they belong to the human species. This interpretation flows from the example which explains how the two meanings of 'fearful' (fearful 'absolutely' and 'to a particular person') may solve the aporia concerning the behaviour of the brave:

the brave person is fearless in front of them [the things absolutely fearful] and endures the things that in a sense are fearful to him and in another not: they are fearful to him qua human being, but qua brave not fearful except slightly, or not at all. (Eth. Eud., III, 1, 1228b 26-30)

The things objectively fearful - that is the things fearful to human nature - in the particular case of the brave person, are the things that are fearful to him 'qua human being' and not fearful to him 'qua brave'. In other contexts of dialectical clarification, based on similar distinctions between a universal and an individual term - taken as two different descriptions of the same thing - the universal term stands for the corresponding genre or species. Considering the contraposition with the expression 'qua brave', it seems clear to me that the expression 'qua human being', in the quoted example, designates the brave as he belongs to the human species, distinguishing him logically from the brave as he is a person with a certain character. If (1) the expression 'qua human being', in the given example, clarifies in what sense an object may be fearful for human nature, and if (2) the brave 'qua human being' is the brave as he belongs to the human species, it turns out that (3) in the Aristotelian argument the notion of human nature corresponds logically to the one of human species.

How and to what extent does belonging to the human species influence the emotional reaction of the brave person?

From an Aristotelian point of view, a fearful emotion entails a representation of the object as fearful and the object itself constitutes the point of reference for the adequateness of the representation. This means that the intensity of the emotional reaction toward a cer-

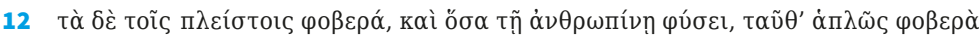

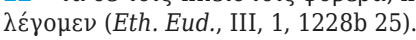


tain object depends, at least in part, on a determinate disposition of the object to produce fear. It is indeed only because the object itself possesses a capacity to produce fear up to a certain degree of intensity that a certain emotional reaction might be adequate to it. For example, if a human being sees an ant, normally, he does not feel fear because the ant is not such as to provoke in him a fearful emotion.

According to Aristotle's view, the capability of the fearful object to provoke a fearful impression, in turn, is measured by human nature. Going back to the example above: the ant does not provoke fear in human beings because it is not fearful for human nature.

If the intensity of fear toward a certain event is, at least partly, determined by the real capacity of the object to produce fear, and if the real capacity of the object to produce fear is in turn measured by human nature, it follows that 'human nature' is in some way characterized by the disposition or capacity of undergoing an impression of the object as productive of fear (in other words as fearful), and that the fearful emotion may be produced in such a capacity. 'Human nature', conceived of in such a way, is one of the elements on which depends the potential reaction of a human being toward the objects of the surrounding world. In some cases, as with the sight of an ant, human beings do not feel fear and therefore it is possible to see nature at work, as an element determining the action. In other cases, as for the coward trembling in front of the ant, nature is, on the contrary, not recognizable as a determinant factor of the action.

\section{Human Nature as a Disposition of the Soul to Endure the Perception of a Destructive Pain}

But how should human nature be construed so that for a human being it would be possible to feel fear? A passage further on in the text (Eth. Eud., III, 1, 1229b 13-21) at the end of the discussion of fearful objects helps, I think, to clarify this point.

In the part of text examined so far, the objects 'absolutely' fearful have been characterized by means of a reference to human nature. Afterwards, they are defined "in a more precise way" (Eth. Eud., III, 1, 1229a 32-33), with reference to the emotion which they provoke. The definition presented in the course of this second discussion is recapitulated at the beginning of the passage which I here quote:

(1) The fearful things therefore in relation to which we speak of a person as brave are, we have said, those that appear likely to cause pain of the destructive kind, (2) provided that these appear close at hand and not far off, (3) and are or appear to be of a magnitude proportionate to a human being; (3.1) for some things must 
necessarily appear fearful to every human being and throw everybody into alarm, since it is quite possible that, just as heat and cold and some of the other forces are above us and above the disposition of the human body, so also are some mental sufferings. (Eth. Eud., III, 1, 1229b 13-21)

(1) In the first part of the passage, Aristotle recapitulates the definition of the fearful objects given in "the more precise examination" which has just ended: the fearful things are those that appear likely to cause a pain of the destructive kind.

It has already been pointed out that a fearful event entails a fearful perception of the object, in other words a representation in the subject of the object that produces fear. In this passage, and in the discussion that it recapitulates, a new element comes into play: a representation to produce fear must be a representation of a pain, more precisely of a destructive kind of pain. A destructive pain, as it has been explained some lines before by Aristotle, is a pain whose nature seems likely to destroy life and hence to lead to death (Eth. Eud., III, 1, 1229a 39-1229b 10). What frightens enormously in death, indeed, is the perception of it as capable of destroying, destroying physically.

The pains of a destructive kind which are the cause of fear are therefore pains capable of producing physical destruction: physical pains that we could call 'violent'. The representation of other kinds of pains, for example psychological pains related to shame, or envy, are identified with other emotions and provoke a different pain from the one generated by fear (Eth. Eud., III, 1, 1229a 35-1229b 1). This latter point has a great theoretical relevance: the representation of a destructive pain is fearful also in the sense that it is accompanied by a true pain. This pain, truly experienced, is typical of fear; it is different from the pains felt in other emotions, which in turn entail a representation of a pain different from the destructive one. It is a psychological pain of the same kind as the one that is envisaged.

(2) In the second part of the passage under analysis, Aristotle adds that the things capable of provoking a destructive pain may generate a pain, on condition that they appear upcoming. This remark on the imminence of pain implies clearly a further point; fear is always a forecast of pain; a forecast which consists in feeling in advance a pain that is expected as upcoming.

(3) In the third part of the passage, Aristotle presents a final condition concerning the fearful objects: the fearful objects, as it concerns their magnitude, must be, or must appear to be, proportionate to a human being. Taking into account the intentional character of fear, the reference to the fearful object's magnitude regards the intensity of the emotion that that kind of object provokes.

As it will be remembered, in the course of the discussion on the objects 'absolutely' fearful, the view according to which human na- 
ture is the measure of the fearful objects was used to explain the possibility that the fear experienced by the coward or the brave person was too much or too little compared to the effective capacity of an event to generate it. In that part of the discussion, the question was the adequacy of the representation regarding reality. Here, in the present passage, the discussion is enriched by new implications.

The research field has been cleared of 'apparent' fearful objects: in other words, the objects fearful 'to somebody'. What is at issue here is the relationship between the representation of an object absolutely fearful (that is a representation faithful to reality) and human nature. The fearful emotion has already been characterized as relating to an upcoming pain which undermines the physical integrity of a human being. Now, to define the fearful objects with reference to the fearful emotion that they produce, one must exclude the case in which the fearful representation is not commensurate to a human being in reason of an excess of intensity.

Before going on with my commentary, an ambiguity in the Aristotelian text needs to be clarified. Given that fear is an emotional representation, namely a representation combined with pain, the reference to the proportion of fear with respect to a human being, in my view, does not mean only that the pain represented must be commensurate to a human being. Since the fearful representation is accompanied by a true pain, it means that even the pain accompanying the representation must be such.

The fact that Aristotle has in mind fearful objects whose magnitude exceeds human nature is quite clear, in my opinion, in the final part of the passage. This part contains a justification of the position previously established according to which the fearful objects must be of a magnitude proportionate to a human being. Commenting on it, Aristotle argues (3.1):

for some things must necessarily appear fearful to every human being and throw everybody into alarm. (Eth. Eud., III, 1, 1229b 17-18)

The statement is exemplified by means of a comparison between the body and the human soul which allows us to explore a hypothesis that seems very plausible for the philosopher. As heat, cold and some other natural forces can be stronger than the disposition of the body to receive them, nothing prevents a similar situation taking place as regards the affections of the human soul. ${ }^{13}$

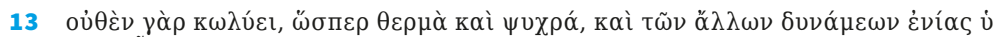

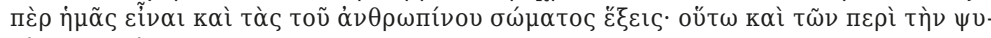

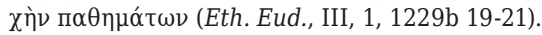


Referring to the things that must necessarily appear "fearful to every human being and throw everybody into alarm"14 Aristotle alludes to a class of fearful objects not mentioned before. ${ }^{15}$ Until now he has discussed: 1) the objects fearful to somebody, which appear fearful to a determinate individual in reason of a determinate character; and 2) the objects absolutely fearful, which are fearful for the majority of people and for human nature. The new class without name is constituted by the objects which appear and are fearful to every human being, and throw everybody into alarm, even the brave person qua brave. These objects, following the Aristotelian comparison, are such as to produce an extremely fearful affection, so fearful to exceed the disposition of the human soul to endure it. If we assume the notion of disposition in the acceptation of 'capacity', we can say that the fearful emotions in question are those which exceed the capacity of the human soul to feel fearful emotion; they exceed it because they are so powerful as to be unbearable.

The extremely intense fear to which Aristotle alludes here entails a foresight of a destructive pain which is so intense that a human being cannot forbear its 'sight'. Considering that the sight is not just cognitive, but it is also accompanied by a pain of the same kind as the one represented, the fearful objects which terrify the human being are also such as to exceed the capacity of the human soul to forbear the pain which accompanies their representation.

The reference to the disposition of the human soul to forbear fearful affections up to a certain degree of intensity, to which Aristotle alludes in his example, fits perfectly to the notion of 'human nature' as a criterion for the definition of the objects absolutely fearful employed in the previous part of the discussion. In this part of the discussion, it will be remembered, 'human nature' was mentioned to indicate a disposition or capacity of a person, as being a member of the human species, to be affected by an object, as it is capable of producing fear.

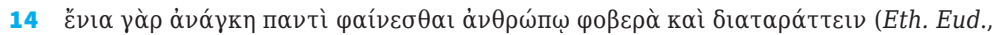
III, 1, 1229b 17-18).

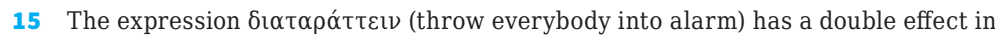
the context of the passage here under analysis. On the one hand it shows that the class of objects discussed in such a passage falls within the group of the fearful objects: in the Rethoric, indeed, the concept of 'throwing into alarm' figures in the definition of fear (Reth., II, 5, 1382a 21-22). On the other hand, the fact that the expression in question appears only at this point of the examination on fearful objects (Eth. Eud., III, 1, $1229 \mathrm{~b} 17-18)$ confirms that the class of object here examined is characterized by the production of fearful impressions that are exceptionally intense - and for this reason it results as heterogeneous compared to the previous ones. 


\section{Human Nature as a Criterion for the Determination of the Voluntariness in the Cases of Mixed Actions}

The notion of 'human nature' mentioned in the discussion on the fearful objects of Eth. Eud., III, 1, in my opinion, is involved also in the famous examination of the cases of mixed action of Eth. Eud., II, 8. More particularly the discussion in Eth. Eud., II, 8 provides a concrete example of the circumstances in which human nature, characterized as a limit of endurance for a destructive pain, constitutes a determinant element for acting and for ethical evaluation. My aim now is to show that in the two mentioned passages, Eth. Eud., III, 1 and Eth. Eud., II, 8, Aristotle refers to the same notion of human nature.

In the discussion on the 'involuntary' of II, 8, the examination of mixed actions follows the examination of an aporia on the self-controlled and the uncontrolled which can be summarized as follows: the self-controlled and the uncontrolled do they act under force, as they are determined by an external principal, or do they act voluntarily (Eth. Eud., II, 8, 1224a 30-36)? Emphasizing the distance from this examination, Aristotle presents the examination of mixed action saying that it will concern the cases in which:

people are said to act under compulsion and of necessity without a disagreement between rational principle ad appetite, when they do something that they consider actually painful and bad but they are faced by flogging or imprisonment or death if they do not do it. (Eth. Eud., III, 1, 1225a 1-6)

The problem is to determine if these actions are forced or voluntary, because in principle:

it is open to them [the agents] not to do them but to endure the penalty threatened. (Eth. Eud., III, 1, 1225a 6-8)

We are here confronted by a group of cases in which the action seems determined by external circumstances; the agent is led to accomplish an action, considered painful and bad, to avoid a threat. In other words, the action is accomplished under the effects of a fearful feeling provoked in the agent by an external threat. According to Aristotle, these kinds of actions may be classed as voluntary or involuntary depending on the case. They are voluntary if the resolution to act rests with the agent: that is if the agent may decide not to act and to undergo the pain threatened. On the contrary, they are forced and so involuntary - at least in a certain way- if the resolution to act or not to act does not rest with the agent. Even if the principle of the action is not external to the agent, the action is forced whether the alternative to it appears as an evil more painful than the action it- 
self, so painful as to compel psychologically the agent to act (Eth. Eud., II, 8 1225a 8 - 1225a 19). ${ }^{16}$

The meaning of 'forced' introduced in the discussion on mixed action is theoretically framed by means of a reference to the notion of 'end'. Aristotle argues that the action is forced, not 'absolutely', but 'for the sake of an end'; the agent's choice, indeed, does not concern the action itself but the end for the sake of which the action is done. The action is forced when something evil is done for the sake of something good, or rather to avoid a greater and more painful pain (Eth. Eud., II, 8, 1225a 16). The violent and compulsory element of the action lies in the fact that the end is chosen on the basis of something external to the agent, a threat of a terrible pain, more powerful than the agent's own capacity to forbear it.

In the following part of the text, it is explicitly stated that in the cases at stake what determines the act is the nature of the agent, which then turns out to be characterized as a limit of endurance for painful affections:

For what rests with himself - and it wholly turns on this - means what his nature is able to bear; what his nature is not able to bear and what is not a matter of his own natural appetition or calculation does not rest with himself. (Eth. Eud., II, 8, 1225a 25-27)

\section{Conclusion}

My analysis has shown that the reference to 'human nature' as a criterion for the definition of the fearful objects, presented by Aristotle in Eth. Eud., III 1, entails a notion of human nature conceived of as a universal characterization of the human species. This characterization concerns the sensible affections. More particularly it concerns fear, as fear involves a representation of a physical pain destructive for a human being and is itself a psychological pain of the same kind. Going into more detail my analysis has shown that human nature, in Eth. Eud., III 1, might plausibly be identified with a disposition of the human soul to endure fearful emotions up to a certain degree of in-

16 Since the starting point of the action is not external to the agent, the action is not forced with reference to the meaning of 'forced' established in the previous part of the discussion, cf. Eth. Eud., II, 8, 1224a 30-36. Aristotle's solution to the problem of the determination of the voluntariness and involuntariness in the cases of mixed action is complex. For reasons of space I provide here only a simplified sketch of the argument. One of the principal interpretative problems is to understand what does 'to rest with the agent' mean. Furthermore, it is ambiguous if that which rests on the agent is the content of the decision between acting or not acting, or if it is even being in the objective situation which implies a decision between the two options. For the former reading (that I put forward here) see Woods 2013; for the latter Simpson 2013. 
tensity. The characterization of certain objects as objectively capable of producing fear in a human being, and the reference to 'human nature' as that in respect of which these objects are objectively fearful, both entail implicitly a conception of human nature as in some way capable of measuring, and thus undergoing, fearful impressions. To this conception perfectly corresponds the Aristotelian description, at the end of Eth. Eud., III, 1, of a disposition of the human soul to forbear certain kinds of affections up to a certain limit of intensity.

In Eth. Eud., II, 8, in the discussion on the 'involuntary', nature is mentioned as a criterion for establishing the involuntariness in the cases of mixed actions: in other words the cases in which the determination to act is compelled by an external threat. Aristotle claims that an action is involuntary (at least to a certain extent) as it has been accomplished to avoid a physical pain or death, inasmuch as the physical pain in question and death are a greater evil than the action which must be accomplished. Ultimately the agent cannot choose to undergo such great evils because they are unbearable for his nature.

In Eth. Eud., II, 8 the nature of the agent is characterized as a limit of endurance concerning certain representations of destructive pains. Since the same notion is identifiable in Eth. Eud., III, 1, it seems to me that in the two passages, Eth. Eud., II, 8 and Eth. Eud., III, 1, the very same notion of human nature is at work. This notion is conceived of as a disposition of the human soul to endure fear up to a certain limit of intensity. Fear, indeed, is a painful affection which consists in the representation of a pain destructive for a human being.

In the ethical domain emotional reactions and the behaviours following on from them are subject to a moral evaluation. A human being scared to death in front of an ant is a coward, whilst a human being who faces death for the good of the state is brave; similarly, an individual who acts to avoid terrible tortures does not act freely but under force and involuntarily. In the examined passages of Eth. Eud., III, 1 (1228b 24-26) and II, 8 (1225a 25-27) human nature serves as a criterion for ethical evaluation: it allows one to determine when an action is brave, and who is a brave person, and to establish the involuntariness of the action in certain circumstances. In my view, an interesting point is that the notion of nature which serves as an ethical criterion is related to sensible affections and not to the rational element of a human being. More particularly, the sensible affections, in respect to which human nature is characterized, are of a painful kind. Furthermore, they do not correspond to any kind of pain but to a particular kind: a pain whose nature is that of being destructive for a human being. Aristotle, it seems to me, has pointed out the ethical relevance of a particular kind of pain: the pain which undermines the physical integrity of a human being. 


\section{Bibliography}

Ackrill, John L. (1974). "Aristotle on 'Eudaimonia'”. Proceedings of the British Academy, 60, 339-59.

Annas, Julia (1996). "Virtue Ethics: What Kind of Naturalism?". Gardiner, Stephen (ed.), Virtue Ethics, Old and New. Ithaca: Cornell University Press, 11-29.

Charles, David (2012). "The 'Eudemian Ethics' on the 'Voluntary'”. Leigh, Fiona (ed.), The Eudemian Ethics on the Voluntary, Friendship, and Luck. Leiden; Boston: Brill, 1-28.

Décarie Vianney (éd.) (1978). Aristote: Éthique à Eudème. Paris; Montréal: Vrin. Destrée, Pierre (2002). "Comment démontrer le propre de l'homme? Pour une lecture 'dialectique' de EN, I, 6". Gilbert, Romeyer-Dherbey (dir.); Aubry, Gwenaëlle (éd.), L'Excellence de la vie. Sur l'"Éthique à Nicomaque" et l'"Éthique à Eudème" d'Aristote. Paris: Vrin, 39-61.

Dirlmeier, Franz (1962). Aristoteles. Eudemische Ethik. Berlin: Akademie-Verlag. Donini, Pierluigi (a cura di) (1999). Aristotele: Etica Eudemia. Roma-Bari: Laterza.

Donini, Pierluigi (2014). Abitudine e Saggezza. Aristotele dall'"Etica Eudemia" alI'"Etica Nicomachea". Alessandria: Edizioni dell'Orso, 139-88.

Grimaldi, William M.A. (1988). A Commentary. Vol. 2 of Aristotle: Rethoric. New York: Fordham University Press.

Inwood, Brad; Woolf, Raphael (eds) (2013). Aristotle: Eudemian Ethics. Cambridge: Cambridge University Press.

Irwin, Terence (2007). The Development of Ethics: A Historical and Critical Study, vol. 1. Oxford: Clarendon Press, 134-52.

Kenny, Antony (transl.) (2011). Aristotle: The Eudemian Ethics. Oxford: University Press.

Lefebvre, David (forthcoming). "Eudemian Ethics" II 8, 1225a2-36: between Force and Nature. II 9, 1225a36-b18: Definition of the Voluntary and the Involuntary $=$ Proceedings of the Symposium Aristotelicum (Athens, July 2017).

Miller, Fred (1995). Nature, Justice and Rights in Aristotle's "Politics". Oxford: Oxford University Press.

Murgier, Christine (2013). Éthiques en dialogue: Aristote lecteur de Platon. Paris: Vrin, 47-54. Textes et traditions.

Natali, Carlo (1989). La saggezza di Aristotele. Napoli: Bibliopolis, 269-71.

Rackham, Harris (transl.) (1981). The Athenian Constitution; "The Eudemian Ethics" On Virtues and Vices. Vol. 20 of Aristotle: Aristotle in 23 Volumes. Cambridge (MA); London: Harvard University Press; William Heinemann Ltd.

Ross, William D. (transl.) (1984). Nicomachean Ethics. Revised by James Opie Urmson. Vol. 2 of The Complete Works of Aristotle: The Revised Oxford Translation. Edited by Jonathan Barnes. Princeton: Princeton University Press.

Simpson, Peter L.P. (ed.) (2013). The "Eudemian Ethics" of Aristotle. London: New Brunswick.

Susemihl, Franz; Apelt, Otto (eds) (1882). Aristotelis Ethica Nicomachea. Leipzig: Teubner.

Woods, Michael (ed.) (2013). Aristotle's "Eudemian Ethics". Book I, II and VII. Oxford: Clarendon Press. 



\title{
Naturalismo e cosmopolitismo nell'Antichità Epicureismo vs stoicismo
}

Pierre-Marie Morel

Université Paris 1 Panthéon-Sorbonne, France

\begin{abstract}
Cosmopolitanism in Antiquity is especially promoted by the cynics and by the stoics. The Epicurean Garden seems to adopt a very different view, according to which justice and laws depend on what is useful for a given political community at a given time. However, the epicurean Diogenes of Oinoanda (fr. 30 Smith) endorses a sort of cosmopolitanism, which contrasts, at first sight, with the traditional contractualism of his school. Nevertheless, in this paper it is argued that Diogenes' cosmopolitanism could hardly be seen as a concession to other schools and that it is consistent with the main principles of Epicurus' political doctrine.
\end{abstract}

Keywords Citizen of the world. Cosmopolitanism. Diogenes of Oinoanda. Epicureanism. Justice. Laws. Political philosophy. Stoicism.

Sommario 1 Introduzione. - 2 Naturalismo epicureo e naturalismo stoico. - 3 La politica epicurea, fra naturalismo e contrattualismo. - 4 Diogene d'Enoanda e l'idea di cosmopolitismo.

\section{Introduzione}

Il naturalismo pratico - intendo con ciò, almeno provvisoriamente, il principio secondo il quale si deve agire in conformità alla natura - si colloca al centro del dibattito etico e politico dell'età ellenistica (che comincia per convenzione con la morte di Alessandro Magno, nel 323 a.C.). Il periodo è caratterizzato in particolare dall'opposizione (diretta o indiretta) fra l'epicureismo e lo stoicismo. Questo dibattito si estende logicamente alla politica e alla conce- 
zione della giustizia e del giusto (to dikaion), di modo che è, secondo me, legittimo parlare di 'naturalismo politico' inteso come un modo di definire la conformità alla natura nel campo politico. C'è un consenso tra entrambe le scuole su questo principio generale, come vedremo. Il problema diviene dunque quello di individuare il tipo di naturalismo politico sostenuto da ciascuna di esse.

Detto questo, non vorrei rimanere al livello, sempre deludente, delle generalità. Il mio punto di partenza sarà un testo poco noto al di là del circolo degli specialisti dell'epicureismo. Si tratta di un piccolo testo del tardo epicureo Diogene d'Enoanda, autore del secondo secolo d.C., il frammento 30 Smith. Questo frammento allude a una sorta di naturalismo politico:

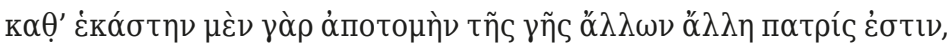

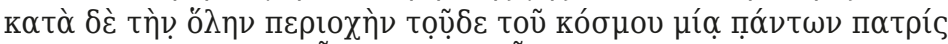

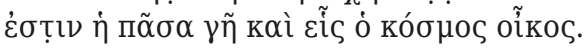

[...abbiamo fatto ciò <i.e. questo scritto> non meno per coloro che sono detti stranieri, ma che in realtà non lo sono affatto.] Poiché, se si considera ogni sezione della Terra, a tal popolo appartiene tale patria, ma se si considera questo mondo nella sua estensione globale, la Terra intera è una sola patria per tutti, e il mondo una sola casa. (Diogene di Enoanda, fr. 30, coll. 1-2 Smith [1993]; trad. dell'Autore)

Ciascun popolo, dice Diogene, ha la sua propria patria, ma se si considera l'estensione globale del mondo, la Terra intera è un'unica patria per tutti, e il mondo un'unica casa o dimora. Questo tema è molto marginale nei testi conservati degli Epicurei antichi. A dire il vero, l'allusione di Diogene è anche un hapax, dato che non troviamo alcuna espressione dell'idea di cosmopolitismo nella letteratura epicurea anteriore. A prima vista, si tratta di un dettaglio della storia dell'epicureismo antico. Però mi sembra molto interessante e significativo, nella misura in cui dà l'opportunità di interrogarsi sul problema molto più generale del cosmopolitismo, inteso come forma di un certo naturalismo politico. Questo tema, nel periodo ellenistico, è soprattutto stoico. Quindi, il fatto che un epicureo sembri raggiungere il campo degli adepti del cosmopolitismo richiede qualche spiegazione, o almeno ipotesi esplicative. È possibile conciliare questo testo con la dottrina epicurea sul diritto o il giusto (to dikaion), una dottrina che, a prima vista, non fa spazio all'idea di cosmopolitismo?

Il testo di Diogene è un frammento dell'ampia iscrizione murale che aveva fatto edificare e incidere nella sua città del sud dell'Anatolia, in Licia, oggi in Turchia. Gli scavi permettono di sperare in nuove scoperte, ma, per il momento, non ci sono altri testi di Diogene che possano perfezionarne l'interpretazione. Dobbiamo dunque accontentarci di ipotesi. 
Quello che vorrei mostrare è quanto segue: il breve testo di Diogene invita a paragonare due concezioni del naturalismo politico, quella stoica e quella epicurea. L'allusione cosmopolitica del frammento 30 di Diogene può essere considerata come una concessione allo spirito del tempo, ma non deve in alcun modo essere vista come una adesione allo stoicismo; essa è anzi perfettamente compatibile con l'ortodossia epicurea, a patto che si prendano in considerazione i motivi particolari dell'autore. Più in generale, questo confronto mette in rilievo il contrasto fra, da un lato, la concezione stoica della conformità alla natura e, dall'altro, quella epicurea.

Prenderò le mosse dalla questione generale del naturalismo e delle sue definizioni a partire dal periodo ellenistico. Vedremo poi come si caratterizza il naturalismo politico epicureo rispetto a quello stoico per provare a capire lo strano testo di Diogene.

\section{Naturalismo epicureo e naturalismo stoico}

Si può dire, senza semplificare esageratamente, che l'epicureismo antico è una filosofia naturalista. ${ }^{1}$ L'esortazione principale dell'etica epicurea, come mostra Epicuro stesso nell'Epistola a Meneceo, è di vivere assumendo il piacere come «principio e fine» della vita buona o della felicità, in quanto il piacere è il nostro «bene primo e a noi congenere» (Ep. Men., 129). Esso è poi, allo stesso tempo, un bene sumphuton, «connaturale» 0 «proprio della nostra natura» (Ep. Men., 129). Così, secondo la massima capitale XXV di Epicuro (Ratae Sententiae $=R S$ ), dobbiamo ricondurre ciascuna delle nostre azioni, in ogni circostanza, «al fine della natura». Nel De finibus di Cicerone, l'epicureo Torquato dichiara che spetta alla natura - ovvero, in questo caso, al piacere e al dolore - giudicare «ciò che è conforme alla natura o contro natura» (quid aut ad naturam aut contra; Cic. Fin., I, 30). Il comportamento dei neonati e delle bestie ci invita d'altra parte ad assumere la natura come maestra e guida (magistra ac duce natura): ${ }^{2}$ tutti ricercano spontaneamente il piacere e il loro atteggiamento, indubbiamente naturale, conferma empiricamente la necessità di regolare la nostra condotta secondo il principio costituito dal piacere. Si tratta dell'argomento detto 'delle culle', l'argument des berceaux, espressione dovuta all'ingegnosità concettuale del rimpianto Jacques Brunschwig (1995).

1 Ringrazio Melania Cassan per la sua attenta rilettura. Il presente articolo amplia alcuni argomenti trattati nel mio Morel 2015, dal quale riprendo qui alcuni materiali. Su Diogene di Enoanda e la politica, cf. Morel 2017.

2 Cic. Fin., I, 71; su questo stesso tema, noto come «argomento della culla», si veda anche Diogene Laerzio X, 137. 
La prima regola di condotta che l'epicureismo prescrive è dunque quella di vivere in conformità alla natura. In ciò, tale indirizzo non differisce radicalmente dalla Stoà. Ad esempio, Zenone di Cizio dichia-

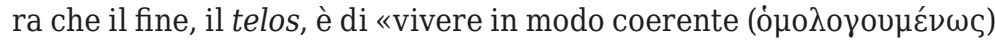
con la natura, ossia vivere secondo virtù». ${ }^{3}$

Tuttavia, la somiglianza raggiunge qui i suoi limiti e le differenze hanno maggior peso. Esse poggiano, nel complesso, su tre punti: la definizione stessa del telos, il modo di manifestazione della normatività naturale, e il retroterra fisico e cosmologico dell'idea di conformità alla natura. Il primo punto di divergenza è il più noto: gli Epicurei considerano come telos il piacere, mentre gli Stoici identificano il bene e il telos con la virtù. Come si sa, combattono il Giardino con forza su questo punto. Usano, anche loro, l'argomento delle culle, ma in senso opposto, per mostrare che i bambini, lungi dal ricercare spontaneamente il piacere, fanno sforzi (talvolta dolorosi) per adempiere al programma fissato dalla natura. Questo contrasto radicale riguarda non solo l'individuazione del telos naturale e personale, ma anche la concezione della condotta morale: mentre gli Epicurei sostengono che il piacere è, allo stesso tempo, principio e fine dell'azione buona, cioè il vero criterio etico, gli Stoici negano al piacere il ruolo di criterio. L'unico criterio morale è la virtù, oppure il 'bello', se si fa riferimento al peso dell'honestum nella restituzione ciceroniana dell'etica stoica, ad esempio nel De finibus. In altre parole, il telos stoico è naturale solo nella misura in cui coincide con la ragione che si manifesta anche come virtù. Vivere in conformità con la natura è necessariamente vivere razionalmente; quindi il piacere, che è un'affezione irrazionale, ci distoglie dalla virtù; di conseguenza non può costituire il telos.

Il secondo punto da segnalare è, secondo me, quello dell'appropriazione, oikeiôsis in greco, commendatio in latino. Non troviamo nei testi epicurei un'idea equivalente a questo elemento centrale della dottrina stoica del rapporto alla natura. Questo aspetto della dottrina stoica è, credo, ben noto: siamo originariamente orientati dalla natura verso l'adempimento del bene e verso ciò che conviene alla nostra natura. L'educazione, l'uso pervertito della ragione e le opinioni false impediscono il compimento diretto del bene pratico e fanno sì che dobbiamo fare tutti i nostri sforzi per vivere in conformità alla natura. Come dice Seneca, «la natura non dà la virtù, divenire un uomo buono è un'arte» (Sen. Ep., 90, 44). Non è tuttavia il caso del saggio, che agisce sempre per virtù e che, dunque, è sempre in conformità alla natura.

Il terzo punto verte sulla concezione della natura stessa. Torniamo a Zenone, portavoce della conformità stoica alla natura. Secondo Ci-

3 SVF I, 179 = Diogene Laerzio, VII, 87; Stobeo, II, 75, 11; trad. it. R. Radice 2002 Cicerone traduce la formula in latino con convenienter naturae vivere (Fin., IV, 14). 
cerone, nel De natura deorum, la sua definizione della natura - che, d'altronde, è stata adottata da tutti gli Stoici - è la seguente: «un fuoco artefice che procede con metodo alla generazione» (Cic. Nat. D. II $57=S V F$ I, 171). Come è palese alla lettura della trattazione ciceroniana, e in particolare nel paragrafo seguente (§ 58), questa definizione contiene in nuce la concezione stoica della natura o del mondo. La natura stoica è una totalità organizzata, diretta dall'interno da una ragione divina e provvidenziale che coincide per l'appunto con il fuoco. Non si tratta del fuoco empirico, quello della fiamma per esempio, ma di un soffio caldo che circola in tutte le parti dei corpi e agisce sulla materia, il principio passivo nella cosmologia stoica. Senza entrare qui in tutti i dettagli della dottrina, e per prendere una scorciatoia, direi che questa definizione determina fortemente il senso dell'idea di 'vita in accordo con la natura': si tratta, secondo gli Stoici, di vivere in conformità alla ragione, all'ordine della provvidenza, specialmente tramite l'accordo con il fato, per alludere a un tema famosissimo della filosofia stoica. In effetti, secondo Crisippo, nel suo libro intitolato I fini:

siccome le nostre nature sono parti del tutto, il fine consiste nel

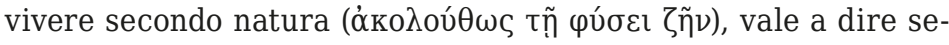
condo la natura propria e del tutto, senza contravvenire in nessuna delle nostre azioni alla legge comune consolidata. Questa è poi la retta ragione dovunque diffusa, presente addirittura in Zeus, il quale presiede alla conduzione del tutto. (Diog. Laert., VII $87=$ SVF III, 4; trad. it. Radice 2002)

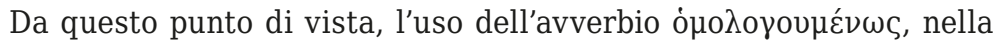
prima formula di Zenone, non è neutro: vivere «in modo coerente» con la natura significa vivere secondo la regola dell'homologia, o coerenza, vale a dire in congiunzione (nel senso naturale, etico e anche logico) con il logos. Di fatto gli Stoici precisano che «la virtù è

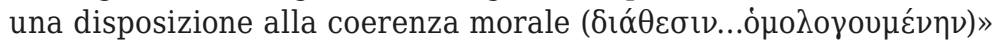
(Diog. Laert., VII 89 = SVF III, 39; trad. it. Radice 2002).

Se torniamo adesso agli Epicurei, è ovvio che la situazione è del tutto diversa. Se intendiamo per 'natura' l'insieme delle cose che sono nell'universo fisico, abbiamo a che fare con un tutto costituito di vuoto e di atomi e privato di ogni normatività. La sua organizzazione locale in 'mondi' è fondamentalmente contingente e provvisoria e non dipende in alcun modo da un disegno intelligente (da un dio oppure da un intelletto cosmico). La natura epicurea, di fatto, non costituisce un ordine in grado di proporre un modello di vita. In questo senso, la conformità alla natura si riduce alla semplice esistenza fisica, tale non poter costituire in sé una regola di condotta sufficiente. 
E, da un punto di vista assiologico, perfettamente neutra: ${ }^{4}$ non soltanto è priva di fini che potrebbero essere trasposti alla sfera dell'azione umana, ma è anche priva di valori. In tali condizioni, vivere in conformità alla natura significa, prima di tutto, essere convinti che il nostro mondo è contingente, che l'universo è fondamentalmente disordinato, e che gli dèi sono indifferenti.

Per riassumere questo primo punto, direi che i naturalismi differiscono in questo: gli Stoici adottano un naturalismo dell'ordine, mentre gli Epicurei propongono un naturalismo del disordine.

\section{La politica epicurea, fra naturalismo e contrattualismo}

Se ci spostiamo adesso sul terreno della politica, la situazione è la seguente: uno dei tratti più famosi della filosofia epicurea è l'esortazione a «vivere nascosto» (Usener 1887, 551) e la sfiducia verso la politica. ${ }^{5}$ La vera sicurezza (asphaleia), quella dell'anima, non ci viene assicurata dalle mura delle città né dalle loro leggi, ma da una vita tranquilla e dall'amicizia ( $R S$ XXVII, XXVIII, XL), lontano dalla folla ( $R S$ XIV).Le preoccupazioni politiche dovrebbero dunque essere classificate, da questo punto di vista, tra le necessità imposte, e si comprende come l'amicizia epicurea possa apparire, fino a un certo punto, come l'alternativa per eccellenza alla vita pubblica. D'altronde, Diogene di Enoanda resta su questa linea. Si capisce dunque l'accusa d'inciviltà mossa dall'antichità contro gli Epicurei, così come una lunga tradizione esegetica secondo la quale non si sarebbero interessati alla politica. In realtà, come hanno bene messo in luce parecchi studiosi a partire dagli anni Ottanta del secolo scorso, la prudenza epicurea rispetto al potere politico, alle cariche pubbliche e alla retorica, non si traduce in un disinteresse teorico. Epicuro ed Ermarco, il suo successore a capo del Giardino nel 270, hanno analizzato con molta attenzione e acutezza lo statuto del dikaion e il suo ruolo nell'organizzazione delle società umane. Anche Lucrezio, benché sia abbastanza discreto su questo punto, allude a più riprese ai problemi che pongono la città e il potere politico per chi vuole vivere nella tranquillità.

4 Ciò non vuol dire che la considerazione di tale assenza di valore oggettivo sia senza conseguenze per la condotta di vita. Come afferma Long (2006c, 205): «The fact that Epicurean nature taken abstractly is without value and purpose does not imply that natural processes have no value relative to human understanding and to human goals». Di fatto, la scienza della natura, la quale stabilisce precisamente che la natura non ha intenti né valori, gioca un ruolo cruciale in etica. Long mostra che non vi è dunque alcun conflitto tra etica e fisica che giustificherebbe il ritrarsi in una sorta di soggettivismo immediato, essendo semplicemente spettatore della natura - come sostiene De Lacy (1957). Anche Long ribadisce, sulle stesse basi, che l'invito epicureo a vivere secondo natura non è un semplice primitivismo, in virtù del quale la scienza della natura avrebbe un ruolo soltanto marginale. 5 Cf. Epicur. RS VII; Sent. Vat. 58; si veda anche Lucrezio, Rer. nat., V, 1120-1135. 
Il fondamento del giusto è naturale o no? È palese che la tradizione epicurea si preoccupa della questione, ma la loro risposta non è chiara, almeno in un primo approccio. Infatti, la concezione epicurea del giusto è una sottile mescolanza di naturalismo e di convenzionalismo. Gli Epicurei, e in primo luogo Epicuro stesso, sono posti di fronte all'alternativa tra due concezioni della giustizia. La prima, in un certo senso 'naturalista', vorrebbe che il giusto traesse la sua definizione e la sua legittimità dalla natura stessa. La seconda, che si può dire 'convenzionalista' oppure 'contrattualista' stabilisce che può esservi giustizia soltanto nell'ambito delle istituzioni umane. ${ }^{6}$ Gli Epicurei, in realtà, non prendono esplicitamente posizione rispetto all'opposizione classica, tematizzata dalla prima Sofistica, tra ciò che esiste per natura, da un lato, e ciò che dipende dalla legge (divina o umana), dall'uso e dalla convenzione (nomos), dall'altro. Ciononostante, essi la rimettono di fatto in questione nel momento in cui analizzano le attività e le istituzioni umane, e in particolare la giustizia.

La difficoltà nel voler definire una politica legittima consiste tutta nel sapere in che modo una comunità umana possa determinare ciò che è giusto. Epicuro esclude implicitamente la possibilità di riferirsi, come nella Repubblica di Platone, a un'idea separata o astratta del giusto, a un paradigma invariabile e immutabile della giustizia in sé:

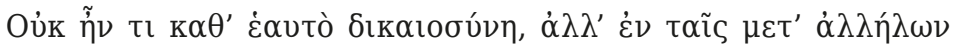

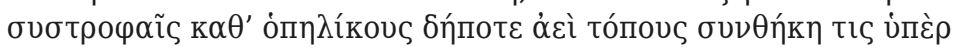

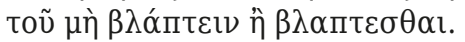

La giustizia (dikaiosunê) non è qualcosa che sia per sé: essa è solo nei rapporti reciproci, dovunque e quante volte esista un patto (sunthêkê) di non fare e di non ricevere danno. (Epicur. RS XXXIII; trad. dell'Autore)

Ciononostante, ogni comunità politica ha bisogno di un criterio del giusto. Esso è fornito dalla comunità stessa nella quale, e a tutela della quale, questa o quella legge viene istituita. È dunque nell'ambito di un patto, e in nessun altro luogo, che il giusto deve essere definito. Da questo punto di vista, dunque, nel dibattito classico che oppone, in politica, contrattualisti e naturalisti, Epicuro opta per la prima posizione: non si danno giustizia e ingiustizia se non vi è un accordo,

6 L'interpretazione convenzionalista è stata particolarmente difesa da Philippson (1910); Goldschmidt $(1977,171)$ per il quale «il n'y a pas, selon Épicure, de droit naturel, mais seulement une nature du droit (celle qui se définit par l'intérêt réciproque)». Si veda anche Vander Waerdt 1987. A favore di un'interpretazione naturalista delle Massime di Epicuro sul dikaoin si sono espressi: Long 2006b; Long, Sedley 1987; Alberti 1995. Per una visione complessiva cf. Morel 2000 e Morel 2007. 
così come non possono darsi per gli animali, né per i popoli che non conoscono rapporti di questo tipo ( $R S$ XXXII).

Tuttavia bisogna su questo punto tener conto dell'importanza della nozione di utilità (to sumpheron) nelle massime di Epicuro relative al dikaion e alla dikaiosunê. Il giusto si definisce in riferimento a ciò che è utile per la comunità reciproca degli uomini, ed è in questo senso 'comune' pur essendo suscettibile di cambiamenti a seconda delle differenze locali e delle evoluzioni dell'utilità comune nel tem-

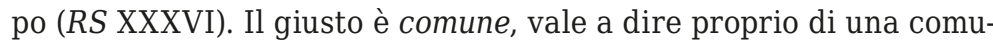
nità; non è dunque 'universale' in senso stretto. Si tratta, per usare la terminologia della Modernità, di una forma di diritto positivo.

Questa idea è probabilmente sottesa alla complessa e oscura nozione di 'segno' (sumbolon), che significa allo stesso tempo 'contropartita', 'simbolo' o 'garanzia', nella $R S$ XXXI:

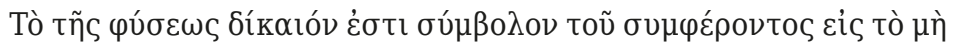

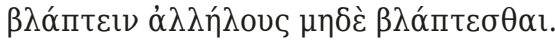

Il giusto per natura è il segno dell'utile, allo scopo di non recare gli uni agli altri danno e di non riceverne. (Epicur. RS XXXI; trad. dell'Autore)

La frase è abbastanza oscura, e ha spesso suscitato la perplessità dei commentatori. Alcuni l'hanno interpretata in un senso convenzionalista. La formula, senza dubbio, non è l'espressione diretta di una sorta di 'diritto naturale'; essa fornisce soltanto un principio generale di regolazione dei conflitti e non una regola chiara che definisca ciò che è permesso fare in materia di giustizia legale.

Tuttavia non significa che il giusto non sia naturale; al contrario si fonda in ultima istanza sull'utile; ora l'utile si definisce sempre, per gli Epicurei, in riferimento alla natura: è utile ciò che conviene ad un certo ente e contribuisce alla sua preservazione, e questo principio vale anche per una comunità, in particolare per la città. Per lo più, poiché l'utile politico (ciò che si rivela utile per una comunità, a un certo punto della sua storia) necessariamente cambia, la diversità delle regole di giustizia e i loro cambiamenti possono essere in accordo con la natura. Da questo punto di vista, la relatività giuridica e la particolarità delle leggi, secondo i luoghi e i tempi (il diritto positivo, se si vuole), non rimettono in discussione la possibilità di riferirsi alla natura. Questo fenomeno è analogo allo sviluppo progressivo del linguaggio evocato nell'Epistola a Erodoto: secondo Epicuro, benché le nostre parole non siano naturali, così come è attestato dalla diversità delle lingue, «i nomi non sono nati in origine per convenzione». Nonostante il linguaggio sia in principio naturale, esso diviene in un secondo momento 'culturale' e differenziato: le lingue si diversificano per effetto della differenza delle affezioni e delle 
impressioni, nonché a causa della necessità di ogni popolo di definire in comune delle regole di designazione linguistica (Epicur. Ep. Hdt., 75-76). Per riassumere: se l'utile, essendo definito dalla soddisfazione dei bisogni vitali, è il referente naturale del giusto, allora il giusto conforme all'utile è allo stesso tempo conforme alla natura. In tal modo, la formula della RS XXXI può avere un senso naturalista, senza con ciò escludere che la giustizia dipenda da un certo accordo politico. Il contrattualismo non è necessariamente in antinomia con il principio di conformità alla natura. Tale lettura presenta il vantaggio di non escludere nessuno dei due orientamenti alternativi che compaiono, di fatto, nei testi stessi.

\section{Diogene d'Enoanda e l'idea di cosmopolitismo}

Torniamo adesso al testo di Diogene di Enoanda e alla questione del cosmopolitismo. Diogene, in effetti, sembra aderire a una forma di universalismo senza precedenti nella tradizione epicurea. Il frammento 30 Smith non è l'unico segno di questa attitudine. Nella sua iscrizione si trovano anche tracce di una vera e propria utopia politica, che descrive una vita in cui gli uomini sarebbero come gli dèi letteralmente: «la vita degli dèi sarà tra gli uomini» -, vivendo nella giustizia e nell'amore reciproco, senza alcun bisogno di leggi né di fortificazioni. Ci si dedicherebbe alla filosofia e ai lavori agricoli nei limiti di ciò che è utile alla nostra natura (frammento $56 \mathrm{Smith}$ ). Sfortunatamente, nessun altro testo epicureo fornisce indicazioni complementari su tale 'età dell'oro' da riconquistare. Probabilmente, essa è da ricollegare al cosmopolitismo che traspare nel frammento 30 dello stesso Diogene di Enoanda. Al relativismo politico e giuridico delle città particolari il saggio epicureo oppone l'ampia prospettiva di una vita comune basata su valori senza confini.

Questo vuol dire che Diogene avrebbe sostenuto una sorta di cosmopolitismo paragonabile a quello che sostengono gli Stoici? Come ho detto prima, quest'ipotesi sarebbe molto difficile da sostenere. In effetti, se prendiamo in considerazione i testi sul cosmopolitismo stoico, vediamo che esso ha caratteri specifici incompatibili con l'epicureismo ortodosso di Diogene d'Enoanda.

Non è possibile esaurire nello spazio di un articolo la complessa questione del cosmopolitismo stoico; mi accontenterò dunque di alcune indicazioni. Prima di tutto, è importante tener presente che non sono gli Stoici gli inventori dell'idea. Diogene di Sinope è generalmente considerato il primo sostenitore di un cosmopolitismo esplicito. ${ }^{7}$ Diogene

7 Sul cosmopolitismo cinico cf. Moles 1996; Scuccimara 2006; Husson 2011; Chapuis 2018, che definisce il cosmopolitismo cinico come una «necessità esistenziale», un co- 
di Sinope, in effetti, diceva che «l'unica repubblica (politeia) corretta è quella dell'universo» (Diogene di Sinope [ca. 414/327 a.C.], ap. Diog. Laert., VI, 72), e sembra essere l'inventore della parola кобноподítпs: «Mentre qualcuno gli chiedeva di dove era, egli rispose: 'sono cittadino del mondo'» (Diog. Laert., VI, 63). ${ }^{8}$ Tuttavia, il cosmopolitismo stoico si allontana chiaramente da questo cosmopolitismo di provocazione e di sovversione dei valori della città. ${ }^{9} \mathrm{Il}$ cosmopolitismo degli Stoici si basa sulla loro concezione generale dell'universo. La legge comune che, sul piano cosmopolitico, si oppone alle leggi delle piccole città, è la legge della ragione, vale a dire quella dell'universo. Non si tratta, come ha mostrato M. Schofield (1991), ${ }^{10}$ di fondare un vero internazionalismo o una città ideale secondo il modello platonico (anche nella Repubblica di Zenone), ma piuttosto di adottare il punto di vista della città cosmica, anche vivendo nella piccola città. Il principio dell'armonia politica universale è in realtà l'armonia cosmica stessa. Vediamo così fino a quale punto questo tipo di naturalismo politico si oppone, non solo al cinismo, ma anche al naturalismo epicureo, che, dal canto suo, respinge ogni concezione della conformità alla natura basata su una presunta armonia cosmica. Per illustrare la tesi stoica, basta citare due testi per altro ben noti. Il primo sottolinea il rapporto fra organizzazione del mondo e cittadinanza cosmica:

Pertanto, chi ha compreso l'ordinamento del mondo ed ha appreso che «di tutte le cose, la più grande, la più elevata e quella più comprensiva è il sistema costituto da Dio e dagli uomini», che da esso sono discesi i semi generatori, non solo di mio padre e di mio nonno, ma anche di tutte quante le cose che sulla terra nascono e crescono e, principalmente, degli esseri razionali, perché essi soli per natura sono in comunione con Dio e con Lui hanno relazione, legati come sono a Dio per la ragione: perché costui non dovrebbe dirsi cittadino del

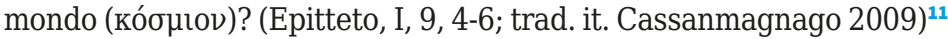

Sarà dunque cittadino del mondo non quello che respinge la piccola città e i suoi valori o aspira ad una città ideale, ma il saggio, cioè quello che vive in armonia con il mondo perché possiede la scienza.

smopolitismo «essenziale» nel senso che non è una conseguenza accidentale delle circostanze, ma l'effetto di una decisione filosofica.

8 Cfr. Luc. Vit. Auct., 8.

9 Per un esempio dell'articolazione della ripresa e della critica del cinismo, incluso il piano politico, si veda Epitteto, III 22. Sul cosmopolitismo stoico, si veda anche: Clemente d'Alessandria (SVF III, 327); Long, Sedley 1987, 67 ecc.

10 Cf. Laurand (2005). Sul cosmopolitismo stoico ed altri aspetti della dottrina politica degli Stoici, cf., più recentemente, Wildberger (2018).

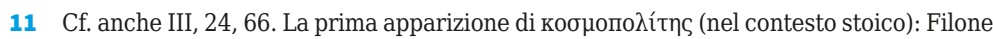
d'Alessandria, De opificio mundi, 3, I, 1,11 Cohn (SVF III, 336); 142-143, I, 50, 2 [SVF II, 528]. 
Non vi è dubbio che questo tipo di cosmopolitismo si basa sulla concezione fisica del kosmos. Ci sono parecchie definizioni del kosmos nei testi stoici; la più chiara per il mio proposito è la seguente:

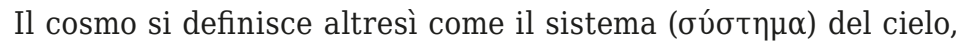
dell'aria, della terra e del mare e delle nature che vi sono comprese; oppure anche come la sede degli dèi e degli uomini e come il sistema dei loro atti e dei loro fini. (Arius D., ap. Eusb., XV, 15, 3-5 $=67 \mathrm{~L}$; trad. it. Radice 2002) ${ }^{12}$

Ora è ben chiaro che il nostro Diogene epicureo non poteva sostenere un cosmopolitismo del genere. La prima ragione, l'abbiamo già visto, è legata alla concezione epicurea dell'organizzazione cosmica, che esclude ogni provvidenza e ogni finalità. La seconda ragione è letterale: Diogene cita questa concezione del mondo e la respinge fortemente in un frammento ancor più interessante perché si tratta del più lungo, finora, della sua iscrizione..$^{13}$ Diogene confuta, in particolare, la tesi stoica secondo la quale gli dèi avrebbero bisogno degli uomini come concittadini (frammento 20, col. I). Quindi, non vi è nessuna concessione allo stoicismo nel frammento 30 di Diogene.

Tuttavia, in questo caso, resta aperta la questione dell'ortodossia di Diogene e della compatibilità del suo cosmopolitismo con la concezione epicurea del giusto. In linea generale, Diogene è considerato molto fedele alla parola di Epicuro, di cui cita direttamente numerosi testi. Su questo punto, mi sembra possibile che Diogene, malgrado questa ortodossia di fondo, si senta libero di prendere altrove le sue formule e i suoi temi. Può tenere conto, come avevo detto all'inizio, dello spirito del tempo, probabilmente più aperto all'idea di cosmopolitismo. Può anche riferirsi a testi anteriori a Epicuro, come nel caso del frammento 68 B 247 DK di Democrito (se ammettiamo la sua autenticità):

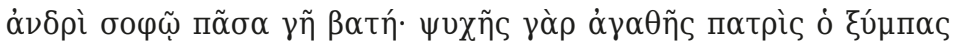

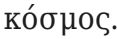

Per l'uomo saggio tutta la terra è percorribile: tutto il mondo è la patria dell'anima buona. (Democrito ap. Stob. III 40.7; DK 68 B 247; trad. Leszl 2009)

13 Questo frammento è stato intitolato da J. Hammerstaedt e M.F. Smith 'Theological Physics-sequence'; è costituito dai frammenti: NF (New Fragment) 167 + NF 126/127 + fr. 20 + NF 182. Cf. Hammerstaedt, Smith (2014). Sulla critica degli Stoici nell'inscrizione di Diogene, si veda Gourinat 2017. 
In Diogene, dunque, troviamo tracce di un tema che sembra costituire, in realtà, un topos, poiché appare, non solo in Democrito, ma anche in Euripide (fr. 777 N.), Tucidide (II 43, 3) o Lisia (Oratio 31, 6). ${ }^{14}$

Eppure, il carattere letterario e abbastanza convenzionale dell'uso diogeniano del topos non dovrebbe condurci a escludere altri motivi, più concettuali. In effetti, se teniamo conto del ruolo dell'utile nella concezione, e anche nella definizione, epicurea del dikaion, non è forzato supporre che Diogene voglia dire la cosa seguente: ci sono delle città, dove il diritto è sempre particolare e relativo a una certa situazione; tuttavia, quando questo diritto è giusto, non è niente di più, in realtà, che la particolarizzazione della prolessi - una prenozione generale e naturale - dell'utile, che rimane sempre la stessa, come Epicuro stesso dice chiaramente nelle massime capitali XXXVIIXXXVIII. Quindi, dal punto di vista di questa prolessi, si può dire che non ci sono confini e che il mondo è una sorta di casa comune. Possiamo dunque dire, come fa Diogene nella prima frase del passo, che «gli stranieri, in realtà non lo sono affatto». Diogene rivendica infatti una certa philanthrôpia in altri frammenti ${ }^{15}$ e, per questa ragione, dedica la sua iscrizione non soltanto ai suoi concittadini, ma anche agli stranieri di passaggio, con i quali condividiamo una stessa «dimora». Da questo punto di vista, la politica coincide chiaramente con l'etica, tanto che il cosmopolitismo, lungi dall'essere un semplice topos, si rivela essere una vera e propria necessità filosofica.

Il frammento 30 di Diogene è rivelatore di un'atmosfera, caratteristica dell'età ellenistica e imperiale, in quanto incorpora, nella concezione epicurea della città e del mondo, un tema comune a parecchie scuole e tradizioni. Questo tema, il cosmopolitismo, rinforza indubbiamente il naturalismo sottile della concezione epicurea del giusto. Nonostante questa eterogeneità, esso è del tutto diverso dal cosmopolitismo stoico, un cosmopolitismo forte, direttamente basato sulla fisica e, per lo più, su una concezione della natura inaccettabile da un epicureo. Il cosmopolitismo di Diogene, in confronto, dà l'impressione di essere un cosmopolitismo debole, oppure un cosmopolitismo etico più che fisico. Comunque sia, rimane coerente con la dottrina del Giardino, e presenta il vantaggio di salvare la speranza di ritrovare un legame fra gli uomini, al di là dei confini, senza dover dipendere da qualsiasi forma di provvidenza. 


\section{Bibliografia}

Alberti, Antonina (1995). «The Epicurean Theory of Law and Justice». Laks, André; Schofield, Malcolm (eds), Justice and Generosity, Studies in Hellenistic Social and Political Philosophy= Proceedings of the Sixth Symposium Hellenisticum. Cambridge: Cambridge University Press, 161-90.

Brunschwig, Jacques (1995). «L'argument des berceaux chez les Épicuriens et chez les Stoïciens». Études sur les philosophies hellénistiques. Épicurisme, stoïcisme, scepticisme. Paris: Presses universitaires de France, 69-112.

Cassanmagnago, Cesare (2009). Epitteto: Tutte le Opere. Milano: Bompiani.

Chapuis, Maxime (2018). Figures de la marginalité dans la pensée grecque, autour de la tradition cynique (Ve-IVe siècles av. J.-C.) [thèse de doctorat]. Paris: Université Paris 1 - Panthéon-Sorbonne.

De Lacy, Phillip (1957). «Process and Value: an Epicurean dilemma». TAPA, 88, 114-26.

Goldschmidt, Victor (1977). La Doctrine d'Épicure et le droit. Paris: Vrin.

Gourinat, Jean-Baptiste (2017). "La critique des stoïciens dans l'inscription d'Enoanda». Hammerstaedt, Jürgen; Morel, Pierre-Marie; Güremen, Refik (éds), Diogenes of Oinoanda - Diogène d'Enoanda. Epicureanism and Philosophical Debates - Épicurisme et controverses. Leuven: Leuven University Press, 165-85. Ancient and Medieval Philosophy - Series 155.

Hammerstaedt, Jürgen; Smith, Martin Ferguson (2014). The Epicurean Inscription of Diogenes of Oinoanda: Ten Years of New Discoveries and Research. Bonn: Habelt Verlag.

Husson, Suzanne (2011). La République de Diogène. Une cité en quête de la nature. Paris: Vrin.

Laurand, Valéry (2005). La Politique stoïcienne. Paris: Presses universitaires de France.

Leszl, Walter (2009). I primi atomisti. Firenze: Olschki.

Long, Anthony A. (2006a). From Epicurus to Epictetus. Studies in Hellenistic and Roman Philosophy. Oxford: Oxord University Press.

Long, Anthony A. (2006b). «Pleasure and Social Utility. The Virtues of Being Epicurean». Long 2006a, 178-201.

Long, Anthony A. (2006c). «Lucretius on Nature and the Epicurean Self». Long 2006a, 202-220.

Long, Anthony A.; Sedley, David N. (1987). The Hellenistic Philosophers. Cambridge: Cambridge University Press.

Moles, John L. (1996). «Cynic Cosmopolitanism». Branham, Robert Bracht; Goulet-Cazé, Marie-Odile (éds), The Cynics. The Cynic Movement in Antiquity and Its Legacy. Berkeley; Los Angeles: University of California Press, 105-20.

Morel, Pierre-Marie (2000). «Épicure, l'histoire et le droit». Revue des Études Anciennes, 102 (3/4), 393-411.

Morel, Pierre-Marie (2007). «Les communautés humaines». Gigandet, Alain; Morel, Pierre-Marie (éds), Lire Épicure et les épicuriens. Paris: Presses universitaires de France, 167-86.

Morel, Pierre-Marie (2015). «Alle origini del contrattualismo. La concezione epicurea del giusto tra natura e convenzione». Iride, 28 (76), 571-82.

Morel, Pierre-Marie (2017). «La Terre entière, une seule patrie. Diogène d'Enoanda et la politique». Hammerstaedt, Jürgen; Morel, PierreMarie; Güremen, Refik (éds), Diogenes of Oinoanda - Diogène d'Enoanda. Epicureanism and Philosophical Debates - Épicurisme et controverses. 
Leuven: Leuven University Press, 221-40. Ancient and Medieval Philosophy - Series 155.

Philippson, Robert (1910). «Die Rechtsphilosophie der Epikureer». Archiv für Geschichte der Philosophie, n.s. XXIII(3), 289-337; 433-46.

Radice, Roberto (2002). Stoici Antichi. Tutti i Frammenti, secondo la raccolta di Hans von Arnim. Milano: Bompiani.

Schofield, Malcolm (1991). The Stoic Idea of the City. Cambridge: Cambridge University Press.

Scuccimara, Luca (2006). I confini del mondo. Storia del cosmopolitismo dall'Antichità al Settecento. Bologna: il Mulino.

Smith, Martin Ferguson (1993). Diogenes of Oinoanda. The Epicurean Inscription. Napoli: Bibliopolis.

Usener, Hermann, (1887). Epicurea. Leipzig: Teubner.

Vander Waerdt, Paul (1987). «The Justice of the Epicurean wise Man», Classical Quarterly, 37, 402-22.

Wildberger, Jula (2018). The Stoics and the State. Theory - Practice - Context. Baden-Baden: Nomos. 


\title{
Riflessioni sul concetto di natura in Lucio Anneo Seneca
}

\author{
Melania Cassan \\ Università Ca’ Foscari Venezia, Italia; Université Paris 1 Panthéon - Sorbonne, France
}

\begin{abstract}
The aim of this short paper is to highlight nature's central role in the constitution and progress of human morality, by analysing nature's multiple characters as displayed in various sections of Seneca's work. First, the focus will extend to man's fundamental propensity to good, which belongs to him by nature. Secondly, a virtuous and happy life will be presented as the life led according to nature. In conclusion, research on natural phenomena will be accounted for, as a building block towards moral perfection. The relationship between all the previous traits, mentioned in the cited passages, constitutes the heart of Seneca's ethical naturalism.
\end{abstract}

Keywords Seneca. Nature. Naturalism. Virtue. Ethics.

Sommario 1 Introduzione. - 2 La naturale predisposizione al bene, la vita vissuta 'secondo natura' e lo studio dei fenomeni naturali.

\section{Introduzione}

Interrogarsi circa la possibilità di definire la filosofia di Seneca una forma di naturalismo etico ${ }^{1}$ sembra possibile solo tornando a riflettere sul concetto di

1 Circa la definizione di naturalismo nell'antichità ci rifacciamo alle osservazioni presentate da Annas (1998, 191-3). In particolare, l'autrice sottolinea la possibilità di concepire una posizione etica naturalistica nell'antichità solo a patto di non interpretare quest'ultima nel senso riduzionista contemporaneo. È possibile parlare di naturalismo etico nel mondo antico riferendosi a quell'approccio che fonda la propria etica sulla natura (Annas 1998, 192). Quando parliamo di 'naturalismo' oggigiorno ci riferiamo invece a un approccio filosofico che affonda le sue radici nella contemporaneità e che impiega, nel suo incedere, categorie di pensiero che non appartenevano alle filosofie dell'antichità. A questo proposito si vedano De Caro 2013, 27 e De Caro, Macarthur 2004.

\section{Philosophica 4}

e-ISSN 2610-8925 | ISSN 2610-8933

ISBN [ebook] 978-88-6969-325-0 | ISBN [print] 978-88-6969-326-7 
natura. ${ }^{2}$ In questa direzione apparirà anzitutto compatibile con l'impianto teoretico di Seneca l'esame del ruolo della natura in relazione all'essere umano e il modo e la misura in cui essa lo determina nel suo cammino verso la virtù. ${ }^{3}$

L'obiettivo di questo breve contributo sarà quindi quello di mettere in luce la centralità del concetto di natura nella costituzione dell'essere umano e nello sviluppo del suo progresso morale, attraverso l'analisi della pluralità di sfumature che esso assume in alcuni luoghi dell'opera senecana. In primo luogo, nella forma dell'originaria apertura al bene che appartiene, per natura, all'uomo. In secondo luogo, nel senso della vita virtuosa e felice se vissuta 'secondo natura' e, infine, nella forma dell'indagine sulla natura come elemento centrale per il progresso morale. Nel fare ciò si mostrerà come la relazione tra i vari sensi in cui natura viene evocata nei luoghi testuali citati dell'opera senecana costituisca il cuore dell'approccio etico intimamente naturalistico di Lucio Anneo Seneca.

\section{La naturale predisposizione al bene, la vita vissuta 'secondo natura' e lo studio dei fenomeni naturali}

La scuola stoica - di cui Seneca si dichiara membro - presenta un sistema tripartito (logica, fisica ed etica) che mostra la strutturale connessione tra ciò che appartiene all'indagine prettamente fisica e ciò che appartiene invece all'indagine etica. Proprio questa dinamica interconnessione tra tutti i campi del sapere ${ }^{4}$ fa sì che, in generale nella filosofia stoica e - come si vedrà in seguito - particolarmente nella filosofia di Seneca, risulti difficile distinguere in maniera chiara i vari significati che natura assume. ${ }^{5}$ Consapevoli di questa complessità e lontani dal voler offrire una trattazione esaustiva del concetto in questione, ci si limiterà, in questa sede, a metterne in luce certi aspetti rinvenuti all'interno di alcuni luoghi testuali senecani.

L'Epistola 108,8 è particolarmente rilevante per la comprensione di un primo significato di natura in relazione alla virtù: la natura in-

2 Numerosi studiosi si sono occupati del concetto di natura nell'antichità; in particolare segnaliamo i recenti lavori di Naddaf (2005) e Cooper (2004).

3 Si veda a questo proposito l'interessante contributo di Irwin (2003, 345-6). Stephens (1994, 275-80) presenta, con ragione, il naturalismo stoico come una forma di razionalismo in quanto il 'vivere secondo natura' significa fondamentalmente 'vivere secondo ragione'.

4 Gill $(2006,145)$ definisce «rich naturalism» l'approccio stoico che include, nella sua analisi olistica del bene, logica etica e fisica.

5 Gauly $(2014,364)$ insiste particolarmente sull'ambiguità del significato di natura in Seneca. Rosenmeyer $(2000,104)$ sottolinea la non sistematicità del pensiero di Seneca circa la natura. 
tesa come naturale predisposizione al bene. La facilità con la quale i discorsi dei filosofi che parlano di virtù, evocati da Seneca all'inizio della lettera, risvegliano in noi il desiderio e la tensione al bene testimonia la nostra naturale apertura a esso. Ciò significa che, in un certo senso, la nostra natura di uomini ci determina in quanto, in qualche misura, definisce ciò che siamo a prescindere dalla nostra volontà. Ci costituisce in quanto uomini. Tuttavia, questa determinazione avviene solo nei termini di una predisposizione, poiché la natura ci definisce ma non esaurisce la nostra autonomia. ${ }^{6} \mathrm{~A}$ questo proposito, l'immagine del seme della virtù, ${ }^{7}$ impiegata dal filosofo in queste righe, è largamente esplicativa: ciò che la natura fornisce non è altro che la possibilità di compiere un'azione virtuosa e non la necessità di aderire a essa. È una forma embrionale di virtù, non la virtù già formata. ${ }^{8}$ Quest'ultima allora è naturale per l'essere umano non nel senso che egli ne è già provvisto, bensì nel senso che è a essa affine, a essa è predisposto. ${ }^{9}$

L'autonomia che si conserva rende centrale il ruolo del contesto all'interno del quale viviamo, poiché esso, per esempio nella forma delle parole dei filosofi, risveglia in noi il ricordo della nostra predisposizione permettendoci di compiere una sorta di 'riappropriazione' di noi stessi, ${ }^{10}$ di messa a fuoco della nostra umanità. Questo movimento di riappropriazione, necessario per il raggiungimento della virtù o saggezza, proprio in quanto si inserisce all'interno di un modello etico che non obbliga a essa, richiede uno sforzo costante e mirato, un esercizio della ragione che si deve accordare con se stessa e con il Tutto di cui è parte. Esso, per essere completo, non implica solamente il riconoscere ciò che è familiare all'individuo, bensì richiede un allargamento di prospettiva da sé al Tutto. In altre parole: la saggezza, la virtù, la vita felice - che in questo caso sono sinoni$\mathrm{mi}$ - esigono un movimento di assenso e adesione alla natura inte-

6 Di questo aspetto si è occupata recentemente Hadot (2014b, 277-9); la studiosa sottolinea la centralità della tensione e dello sforzo individuale per il raggiungimento della virtù.

7 Una ulteriore immagine utilizzata da Seneca per indicare lo stato embrionale della virtù nell'essere umano è quella della scintilla in Ep. 94, 29.

8 L'idea che la virtù nella sua forma compiuta non sia data all'uomo per natura è espressa da Seneca in Ep. 90, 44-46.

9 Ci poniamo sulla stessa linea di Hadot $(2014 a, 14)$ la quale, all'interno di un recente saggio sul tema della formazione del concetto di bene nello Stoicismo, sottolinea il carattere 'innato' della predisposizione umana alla virtù, non della virtù pienamente realizzata.

10 Il riferimento immediato è qui a ciò che gli Stoici antichi chiamavano oikeiosis Consapevoli della complessità della tematica in questione la quale porta con sé numerose problematiche interpretative, ci limitiamo, in questa sede, a sottolineare il ruolo attivo della ragione nel processo di riconoscimento di ciò che ci appartiene, come ben evidenziato da Engberg-Pedersen (1990, 45-6). 
sa sia nel senso più generale di cosmos ordinato e strutturato da un principio razionale (Logos) e da leggi (nomoi) sia nel senso di natura umana dotata di razionalità (logos) la quale è poi, come si è detto, parte della prima. L'interazione e l'armonizzazione tra i due livelli di natura, umana e cosmica, costituiscono il cuore del celeberrimo 'vivere secondo natura' tanto caro anche a Seneca.

Precisamente in questo senso, all'interno di De vita beata 3, 3 la natura viene evocata:

Nel frattempo, e su questo punto gli stoici sono tutti concordi, do il mio assenso alla natura (rerum naturae adsentior); è saggezza il non allontanarsi dalla natura e conformarsi alla sua legge (legem) ed al suo esempio. Concludo: la vita è felice, se è consona con la propria natura, ${ }^{11}$ ma a tanto non si può giungere se, in primo luogo, la mente non è sana, anzi, se non è in continuo possesso della sua sanità, poi se non è forte e volitiva, inoltre, se non è straordinariamente paziente, capace di adeguarsi alle singole situazioni, interessata, ma senza ansie, al proprio corpo ed a quanto lo concerne, ed anche amante di tutte le altre cose che ornano la vita, senza entusiasmi di sorta, pronta infine ad usare i doni della fortuna, senza farsene schiava. (De vita beata 3,3; trad. it. Marastoni 2012)

L'adsensus che siamo invitati a dare alla natura e alle sue leges, evocato nel testo, mette in evidenza, da una parte, il ruolo attivo dell'essere umano per raggiungere la saggezza, facendo della virtù qualcosa che va attivamente conquistato, e, dall'altra, il carattere fortemente normativo della natura, la quale funge da modello esemplare (exemplum) per l'uomo virtuoso. Seneca ci costringe, in questo modo, a operare un interessante cambio di prospettiva: da una parte, la natura, intesa come naturale predisposizione al bene, non è sufficiente alla virtù. In questo senso, la natura non basta. Dall'altra, però, ciò che colma questa 'mancanza' è l'adesione alla natura stessa e alle sue leggi. $\mathrm{Ma}$, se aderire alla natura e alle sue leggi significa, come abbiamo visto, accordare il proprio principio razionale con il principio razionale del Tutto, allora quel 'vivere secondo natura' significa, da ultimo, recuperare volontariamente l'apertura al bene e condurla alla piena realizzazione. Significa, per non abbandonare l'immagine precedentemente evocata, fare in modo che quel seme di virtù diventi pianta

11 Crediamo sia utile e possibile interpretare 'propria natura' sia nel senso di 'propria natura di essere umano', sia nel senso di 'propria natura individuale'. Ciò poiché non crediamo sia contraddittorio supporre che qui Seneca stia pensando sia alla natura dell'uomo in quanto uomo, ossia di essere dotato di ragione, sia alla natura del singolo individuo, poiché essa, nell'uomo virtuoso, nel saggio, non è in contraddizione con la propria umanità, anzi la caratterizza ulteriormente. 
rigogliosa. Nello stesso passo poi, l'autore sceglie di elencare le condizioni di possibilità della vita felice e saggia. Questa scelta risulta particolarmente interessante poiché sottolinea, ancora una volta, l'importanza della presenza e dell'interazione di tutti i livelli di natura, per raggiungere la saggezza. Non a caso, infatti, Seneca descrive le caratteristiche della mens ${ }^{12}$ in grado di sviluppare la virtù, delineando una sorta di progressivo passaggio dall'ordine dell'individuo all'ordine della fortuna, non trascurando di dare il giusto rilievo alle condizioni contestuali del vivere. Le prime caratteristiche elencate la mente sana, la sua costanza, forza e volizione - parlano della relazione della mente con se stessa; secondariamente, è presa in considerazione la sua relazione con l'ambiente, il contesto in cui si trova a operare, nella forma delle situazioni da affrontare e del suo rapporto con il corpo..$^{13}$ Infine, è chiamato in causa il rapporto con la fortuna, il quale pone immediatamente l'attenzione sul piano cosmologico.

Le prime due accezioni di natura - naturale apertura al bene e vita vissuta secondo natura - hanno un carattere evidentemente etico; ve n'è, però, una terza che Seneca utilizza soprattutto all'interno delle Naturales Quaestiones (QNat.). ${ }^{14}$ L'impianto chiaramente scientifico che Seneca conferisce a quest'opera fa sì che sia piuttosto legittimo da parte del filosofo conferire a 'natura', in alcune occasioni, il significato generale di 'fenomeni naturali'. ${ }^{15}$

Di primo acchito si potrebbe confondere l'evidente interesse scientifico dell'opera con il senso che essa assume, a detta di Seneca, nella sua complessità. Vi è il rischio infatti di ritenere che QNat. sia un mero catalogo descrittivo di alcuni fenomeni naturali terrestri e celesti, più o meno frequenti.

L'attenzione invece va posta sul fatto che l'interesse sotteso alla ricerca naturale è, per Seneca, caratterizzato eticamente. Infatti, il compito del filosofo/scienziato è sì quello di indagare la natura,

12 Mens, segnala Smith $(2014,347)$, è spesso impiegato da Seneca come sinonimo di animus, ossia il centro dell'attività psichica a cui tutto fa capo; l'hêgemonikon degli Stoici antichi. Questo rilievo, dato alle condizioni che la mente deve possedere per poter accordarsi alla natura, sottolinea, ancora una volta, la matrice razionalistica del naturalismo senecano.

13 È nota la problematica del rapporto anima-corpo nella filosofia di Seneca. Egli è per lo più considerato, in seguito alle influenze platoniche, un dualista: così per esempio Smith 2014, 361. La considerazione del corpo come qualcosa che è - in qualche modo estraneo all'anima (intesa come animus/mens) giustifica, in questo passo, la considerazione del corpo accanto alle 'cose che ornano la vita', che non sono essenziali a essa.

14 Si è occupato delle implicazioni etiche ed estetiche delle QNat. Gunderson (2015, 56-74). Della stessa opera si sono occupati Berno (2015) e Rosenmeyer (2000, 104-16) che ne hanno descritto i tratti essenziali sia a livello di stile letterario che a livello contenutistico. Donini $(1979,209-42)$ ha portato magistralmente alla luce l'originalità di Seneca rispetto allo Stoicismo ortodosso nelle QNat.

15 Vi sono numerosi passaggi che presentano questo significato del termine in questione, a titolo di esempio: QNat. 6,3,2; 6,4,2; 6,30,2. 
di cogliere i meccanismi che la governano, di liberarsi dall'ignoranza, ma ciò è funzionale, in ultima analisi, a elevare il proprio spirito alla dimensione della virtù, ${ }^{16}$ come risulta chiaramente dal passo:

Ecco ora considerazioni volte a fortificare gli animi: a noi importa che divengano più forti che dotti. D'altra parte l'una cosa non va senza l'altra; l'animo non acquisisce forza che con i buoni studi (bonis artibus) e l'osservazione della natura (contemplatione naturae). (QNat. 6,32,1; trad. it. Mugellesi 2004)

Il valore dello studio dei fenomeni naturali può essere compreso appieno, a nostro parere, alla luce di quel 'vivere secondo natura' sopra menzionato. Codesto studio costituisce una delle condizioni per poter compiere l'atto di assenso stoico nei confronti della natura stessa, poiché disvela all'uomo che vuole diventare virtuoso quella natura e quelle leggi naturali secondo cui è chiamato a vivere per realizzarsi pienamente in quanto uomo. Esso permette di conoscere ciò a cui 'accordarsi'. Infatti, se vivere in accordo con la natura significa riconoscere il principio razionale che la governa per potersi infine riconoscere come parte di esso, è chiaro che studiare - cioè conoscere secondo ragione - i venti, i fuochi celesti, le acque terrestri, le comete e gli altri fenomeni naturali è il primo passo verso l'adesione a essa. Grazie all'indagine sulla natura possiamo inoltre, tramite l'individuazione delle concatenazioni causali che la permeano, liberarci dal turbamento provocato - particolarmente nel caso degli eventi eccezionali come i terremoti descritti nel sesto libro delle QNat. - dalla scorretta comprensione di questa. I fenomeni naturali rari, in quanto non familiari, provocano in noi un sentimento di paura (metus) poiché interpretiamo, a torto, la scarsa frequenza con la quale accadono come una stranezza e non come una mera rarità. In altre parole: ignorare la verità della natura significa conferirle, con superstizione (religio) (QNat. 6,3,3), caratteristiche che essa non ha. Potremmo dire, interpretando le parole di Seneca (QNat. 6, 3,1), che questo atteggiamento anti-filosofico attribuisce proprietà 'non naturali' alla natura stessa, a essa non pertinenti: ignora che la natura, nella sua razionalità, basta a se stessa per essere spiegata e non necessita di alcuna ragione estrinseca, esterna. Ma leggere la realtà con gli occhi della ragione, senza fermarsi alla fallace superficialità (QNat. 6,3,2) e guadagnando così la securitas, l'imperturbabilità, anche di fronte agli eventi più spaventosi, non è altro che un aspetto imprescindibile di quel processo di riappropriazione di sé, di tensione verso la piena realizzazione della propria umanità: vivere secondo la propria natura di esseri umani in armonia con la natura del Tutto. 
Concludendo, dalla breve serie di riflessioni fin qui sviluppate risulta interessante sottolineare la centralità della natura, nelle accezioni che assume all'interno dei contesti in cui è evocata, nel processo di acquisizione della virtù ma anche nel momento della sua piena realizzazione. Essa infatti è presente, in maniera costituente, sia all'inizio del processo, come predisposizione naturale, sia durante il processo, come oggetto di studio, sia alla fine del processo in quanto fonda normativamente la vita del saggio. Ci sentiamo in grado di affermare, pertanto, che le tre declinazioni di 'natura' qui delineate si rivelano non solo complementari, nella misura in cui rendono pregnante e saliente l'altrimenti vago terminus communis 'natura', ma anche reciprocamente necessarie, nella misura in cui illuminano a vicenda la loro, solo apparentemente indipendente, significanza.

\section{Bibliografia}

Annas, Julia (1998). La morale della felicità in Aristotele e nei filosofi dell'età ellenistica. Milano: Vita e Pensiero.

Berno, Francesca Romana (2015). «Exploring Appearances: Seneca's Scientific Works». Bartsch, Shadi; Schiesaro, Alessandro (eds), The Cambridge Companion to Seneca. Cambridge: Cambridge University Press, 82-92.

Chaumartin, François-Régis (1996). «La nature dans les Questions Naturelles de Sénèque». Lévy, Carlos (éd.), Le concept de nature à Rome. La physique. Paris: Presses de l'École Normale Supérieure, 177-90.

Cooper, John M. (2004). Knowledge, Nature and The Good: Essays on Ancient Philosophy. Princeton: Princeton University Press.

De Caro, Mario (2013). "Naturalismo scientifico e naturalismo liberalizzato». Summa, Michela; Giuffrida, Pietro (eds), Naturalism and Subjectivity. Metodo. International Studies in Phenomenology and Philosophy, 1(2), 27-37.

De Caro, Mario; Macarthur, David (eds) (2004). Naturalism in Question. Cambridge (MA): Harvard University Press.

Donini, Pierluigi (1979). «L'eclettismo impossibile. Seneca e il platonismo medio». Donini, Pierluigi; Gianotti, Gian Franco, Modelli filosofici eletterari: Lucrezio, Orazio, Seneca. Bologna: Pitagora Ed., 149-300.

Engberg-Pedersen, Troels (1990). The Stoic Theory of Oikeiosis. Moral Development and Social Interaction in Early Stoic Philosophy. Aarhus: Aarhus University Press.

Gauly, Bardo Maria (2014). «Physics II: Cosmology and Natural Philosophy». Damschen, Gregor; Heil, Andreas (eds), Brill's Companion to Seneca: Philosopher and Dramatist. Leiden; Boston: Brill, 363-78.

Gill, Cristopher (2006). The Structured Self in Hellenistic and Roman Thought. New York: Oxford University Press.

Gunderson, Eric (2015). The sublime Seneca: Ethics, Literature, Metaphysics. Cambridge: Cambridge University Press.

Hadot, Ilsetraut (2014a). «Getting to Goodness: Reflections on Chapter 10 of Brad Inwood, Reading Seneca». Wildberger, Jula; Colish, Marcia L. (eds), Seneca Philosophus. Berlin; Boston: De Gruyter, 9-41. 
Hadot, Ilsetraut (2014b). Sénèque. Direction spirituelle et pratique de la philosophie. Paris: Librairie philosophique J.Vrin.

Irwin, Terence H. (2003). «Stoic Naturalism and Its Critics». Inwood, Brad (ed.), The Cambridge Companion to the Stoics. Cambridge: Cambridge University Press, 345-64.

Marastoni, Aldo (trad.) (2012). «Seneca: La vita felice». Reale, Giovanni (a cura di), Seneca: tutte le opere. Dialoghi, trattati, lettere e opere in poesia. Milano: Bompiani, 157-84.

Mugellesi, Rossana (a cura di) (2004). L. Anneo Seneca: Questioni naturali; Introduzione, traduzione e note di Rossana Mugellesi. Milano: BUR.

Naddaf, Gerard (2005). The Greek Concept of Nature. Albany: State University Of New York Press.

Rosenmeyer, Thomas G. (2000). «Seneca and Nature». Arethusa, 33(1), 99-119.

Smith, R. Scott (2014). «Physics I: Body and Soul». Damschen, Gregor; Heil, Andreas (eds), Brill's Companion to Seneca: Philosopher and Dramatist. Leiden; Boston: Brill, 343-61.

Stephens, William O. (1994). «Stoic Naturalism, Rationalism, and Ecology». Environmental Ethics, 16(3), 275-86. 


\title{
Onnipotenza divina e ordine naturale nel Medioevo L'immutabilità del passato come garanzia del rispetto del corso della Natura
}

Andrea Possamai

Università Ca' Foscari Venezia, Italia

\begin{abstract}
The present essay aims, on the one hand, to recall the reasons of anti-naturalism, intended in a metaphysical perspective, of a large part of medieval philosophical and theological reflection and, on the other hand, to show how the same type of problems, specifically those concerning the possible mutability or immutability of the past, can be employed in favour of various conflicting positions on the matter. To demonstrate this, reference was made to some thinkers who could represent emblematic positions on the theme, in particular: Pliny the Elder for the ancient world, Augustine of Hippo, Peter Damian, Bonaventure and Thomas Aquinas for the medieval era.
\end{abstract}

Keywords Change. Past. God. Naturalism. Medieval philosophy.

Sommario 1 Naturalismo e Onnipotenza. - 2 Modificabilità del passato e ordine naturale. -3 Conclusione.

\section{$1 \quad$ Naturalismo e Onnipotenza}

Il pensiero medievale, nel suo complesso, sembra essere assai distante da quella concezione del naturalismo, inteso come dottrina metafisica, secondo cui la realtà si esaurisce nella natura (Papineau 2016). Il complesso delle leggi e delle forze che costituiscono il mondo fisico non è ritenuto adeguato come primo principio del tutto. In gran parte del pensiero medievale, infat- 
ti, la figura di un Dio trascendente e creatore che può intervenire a suo piacimento sulla natura, non lascia spazio a una assolutizzazione dell'ordine naturale e delle sue leggi. Senza dover necessariamente impostare un confronto con la contemporaneità per mettere in risalto tutto ciò, basta osservare il modo in cui un autore antico come Plinio il Vecchio parla della natura nella sua Naturalis historia e misurare la distanza con quanto fecero poi diversi importanti pensatori medievali. Nell'incipit del secondo libro, quello trattante della cosmologia, Plinio ci presenta un mondo, intendendo questo termine nel suo significato più ampio, come coincidente con il tutto e come equivalente alla natura stessa (Plin. HS II, 7 [1]). Le caratteristiche che gli vengono attribuite, tra le quali di essere eterno, sacro e infinito, non solo pongono in dubbio la sensatezza di investigare ciò che sta al di là dei suoi limiti, ma rendono, a giudizio di Plinio, risibili i tentativi di voler dare una immagine o una forma a Dio. Il fatto stesso che possa essere un'entità separata, seppure sollevato come problema, dal proseguo e dalla conclusione del testo viene escluso. La religione politeista del tempo, con le sue numerosissime divinità e la varietà di pratiche religiose, viene presentata sotto una cattiva luce, fino a che, dopo aver esposto una breve lista di quello che nemmeno Dio può fare, si ricava da ciò la conclusione che il potere della natura altro non sia se non ciò che noi chiamiamo Dio (Plin. HS II, 7 [5]). ${ }^{1}$ La breve lista che ci viene presentata di ciò che neppure Dio non può realizzare risulta per noi assai importante: prima di tutto perché porta a far coincidere Dio con la natura partendo dalla parità di estensione del potere di entrambi, ossia, in sostanza, mostra come ciò che è impossibile a Dio coincida con quanto è impossibile alla natura, riducendo così l'estensione del potere divino a quanto rispetta l'ordine naturale e poi perché ci permette di istituire un confronto con quanto nel pensiero medievale può essere fatto valere come emblema della disparità tra l'azione divina e i limiti naturali, vale a dire la riflessione sull'estensione dell'onnipotenza divina.

La riflessione filosofica e teologica medievale ha dovuto in effetti fare i conti con un dato scritturistico che non solo ha portato al sorgere della concezione secondo cui la divinità, Dio, è onnipotente, ma anche con una serie di innumerevoli eventi che sembrano non rispettare l'ordine naturale e per questo presero a volte il nome di miracoli. Si pensi a quanto contenuto sia nell'Antico che nel Nuovo Testamento: un roveto che pur bruciando non si consuma, un mare apertosi in due giusto il tempo per far passare un popolo in fuga, un bastone secco da cui dopo un giorno emergono fiori e frutti, una vergine che partorisce, dell'acqua che si trasforma in vino, un cieco dalla nasci-

1 Questa posizione non era del resto affermata solo da Plinio nell'antichità, si pensi ad esempio a quanto sostenuto dallo stesso Seneca nel De Beneficiis (I, IV, VII). 
ta che recupera la vista, un morto che dopo più giorni torna in vita e dei morti che resuscitano, ecc. A questo si aggiunga anche una serie di credenze o di avvenimenti che nella cultura del tempo venivano dati per certi e che, anche per mancanza di conoscenze scientifiche, venivano apertamente considerati come contrari alle leggi di natura. Sentiamo parlare, ad esempio, di animali che riescono a vivere in mezzo alle fiamme, delle proprietà incredibili della paglia e della calce, del sangue di capro in grado di scalfire il diamante, di cavalle fecondate dal vento, di uccelli che nascono dai frutti di alcuni alberi e di innumerevoli altri prodigi. ${ }^{2}$ Infine si aggiunga a tutto ciò la stessa immaginazione e curiosità dei pensatori medievali e la loro volontà di indagare i limiti della divina onnipotenza. ${ }^{3}$ Certamente anche nel mondo pagano si era a conoscenza di fatti naturali considerati straordinari e gli stessi miti ne riportavano molti, tuttavia il modo di rapportarsi con i testi sacri o comunque con i racconti su ciò che perteneva alla divinità, tanto da parte dei comuni fedeli, quanto, soprattutto, da parte dei pensatori, era assai diverso. La riflessione sull'onnipotenza divina e il suo rapporto con tali eventi è propria del mondo medievale, basti considerare lo spazio e l'importanza riservati nelle proprie opere a questi temi da parte dei pensatori antichi da un lato e dai pensatori medievali dall'altro.

Il problema diviene allora quello di considerare complessivamente il modo in cui fu interpretata questa relazione tra onnipotenza e ordine naturale nei pensatori medievali e per farlo ci rifacciamo al pensiero di due autori che rappresentano due posizioni apparentemente in contrasto sulla questione. Da un lato Agostino d'Ippona e dall'altro Pier Damiani, da un lato l'idea che Dio non agisca mai realmente contro natura, cioè, ad esempio, contro le leggi che regolano l'accadere dei fenomeni naturali, e dall'altro l'idea che la natura sia completamente sottomessa al suo creatore, il quale può agire su di lei a suo piacimento. Secondo Agostino Dio non fa nulla contro natura, al massimo agisce contro quello che è da noi considerato come il comune corso della natura. Rispondendo a Fausto manicheo, dopo che egli si era espresso sull'agire in molti casi contro ciò che è lecito in natura da parte di Gesù, Agostino è chiaro: è Dio l'artefice della natura, pertanto qualsiasi sua azione sulla natura è naturale e diviene parte dell'ordine naturale (c. Faust., XXVI, 5; PL 42, 480-481).

2 Pier Damiani, De divina omnipotentia (da ora De div. omnip.), 11; Patrologia Latina (d'ora in avanti $P L$ ) 145, 612 C- 613 B. Lo stesso Agostino fa riferimento a simili eventi nel De Civitate Dei (XXI,4-8; PL 41).

3 Ci si può imbattere ad esempio nei seguenti interrogativi: Può Dio trasformare un uomo in un asino? Avrebbe potuto incarnarsi in una simile bestia? Potrebbe creare una pietra che Egli stesso non può sollevare? Può trasformare del pane in un angelo o un tronco in un vitello e viceversa? Per quanto stravaganti alcune di queste questioni meriterebbero davvero un approfondimento. Si veda a riguardo Kennedy 1989. 
Dio stesso, stando alle parole dell'Ipponate, rappresenta la somma legge della natura. Contro natura è dunque solo ciò che a noi umani, a causa della nostra ignoranza, appare come inconsueto.

Pier Damiani si esprime invece in maniera assai differente. Nel De divina omnipotentia prende posizione contro il modo di argomentare di quelli che lui chiama "dialettici", contro le loro sicurezze fondate sulla logica e, ancor prima, sul modo di funzionare della natura. I giochi verbali che riguardano il concatenamento logico dei ragionamenti non devono oscurare la fede nell'onnipotenza divina (De div. omnip., 10; PL 145, 610 D, 611 B). Alla base di tutto ciò si trova del resto la differenza nel concepire ciò che è impossibile alla natura e ciò che è impossibile a Dio. Per il Damiani è impensabile quella coincidenza tra il potere della natura e Dio che abbiamo ritrovato in Plinio (De div. omnip., 11; PL 145, 612 A-C). Quanto sostenuto da Pier Damiani da un lato si trova in accordo con quanto affermato da Agostino, specialmente quando sottolinea che la natura, essendo creata da Dio, ne rispetta sempre le volontà, ma dall'altro lato mette anche in luce, attraverso il suo modo di esprimersi, che tutte quelle che sono le leggi, l'ordine, la necessità, che appartengono alla natura e che vi appartengono per sé e non per noi, come invece sosteneva Agostino, sono sottoposte all'arbitrio divino. Dio può modificare le leggi e l'ordine naturale, può strappare la necessità alla natura, può agire perfino contro natura, insomma, essa è sottoposta al potere assoluto di Dio. Dio e la natura non possono pertanto venire equiparati.

A questo punto allora, volendo riuscire a mettere a fuoco, al di là delle diverse prospettive, ciò che a nostro avviso accomuna i pensatori medievali e li pone su un altro versante rispetto agli autori antichi come Plinio, dobbiamo dire che per essi è fondamentale evitare quell'errore che consiste nel confondere quanto è possibile alla potenza divina con quanto riteniamo essere possibile alla natura. Che del resto sia un errore pernicioso e che sia necessario essere messi in guardia in proposito per evitare il sorgere di assurde credenze sul divino, lo si evince dalla innumerevole quantità di autori che, trattando nelle loro opere la materia dell'onnipotenza divina, hanno sempre riservato uno spazio alla delineazione delle differenze tra l'estensione del potere divino e quello della natura. Si prendano come esempio due maestri della scolastica del XIII secolo come Bonaventura da Bagnoregio e Tommaso d'Aquino. Il primo, nel suo commento alle Sentenze, affronta il problema se Dio possa qualunque cosa sia impossibile ad un agente creato, mentre il secondo, sia nel suo commento alle Sentenze, sia nelle questioni disputate sulla potenza divina, si dedica all'esplicita domanda se Dio possa ciò che è impossibile 
alla natura. ${ }^{4}$ Simili questioni, e altre ad esse legate, ${ }^{5}$ mostrano come anche nella speculazione medievale più matura l'estensione del potere divino sia considerata ben più ampia rispetto a quanto possibile alla natura. In questi autori si fa però più precisa la distinzione tra i diversi modi in cui si può dire che qualcosa sia impossibile, chiarendo così ciò che è irrealizzabile nel corso ordinario della natura e ciò che è irrealizzabile anche da Dio. Bonaventura distingue quattro modi in cui si può dire che qualcosa sia impossibile, mentre Tommaso tre, entrambi tuttavia concordano nel sostenere che alcune cose siano impossibili sia a Dio che alla natura, mentre altre solamente alla natura, ma non a Dio. Queste ultime prendono poi il nome di miracoli e si afferma, in accordo con Agostino, che Dio non operi mai contro natura, ma solo contro l'ordine naturale ordinario. Quali siano poi le cose impossibili unicamente alla natura e quelle impossibili anche a Dio non è facile stabilirlo, in quanto davvero moltissimi autori si sono confrontati su questo problema arrivando a conclusioni assai diverse. Ci soffermeremo brevemente pertanto solo su una tematica, la quale però è tra le più diffuse ed emblematiche e ci permette, tra l'altro, di riconnettere tra loro tutti i pensatori con cui finora ci siamo confrontati.

\section{Modificabilità del passato e ordine naturale}

Tra le diverse questioni concernenti l'onnipotenza divina una di quelle che hanno avuto maggior fortuna e di cui si può individuare una storia che non solo abbraccia l'intera epoca medievale, ma perfino quella antica e moderna, è sicuramente quella relativa alla possibile modificabilità del passato. Già Aristotele nell'antichità vi faceva riferimento (Eth. Nic., VI, 1139b ss.) e anche Plinio, come abbiamo visto, vi si riferisce per mettere in mostra come, proprio perché né Dio né la natura possono riuscire a modificare il passato, il loro potere e quindi la loro essenza finiscono per coincidere. Plinio sottolinea come, tra le altre cose, Dio non abbia giurisdizione sul passato e non possa fare in modo che chi ha vissuto non abbia vissuto. Il modo di sfruttare questo tipo di problematica all'interno della questione che stiamo affrontando sarà del resto tra i più diversi. In questo caso, co-

4 Bonaventura da Bagnoregio, Commentaria in quatuor libros Sententiarum (da ora: Sent.) I, dist. 42, q. 3; Tommaso d'Aquino, Scriptum super libros Sententiarum (da ora: Sent.), I, dist. 42, q. 2, a. 2; Quaestiones disputatae de potentia Dei (da ora: Q. disp., De potentia), q. 1, a. 3.

5 Si vedano ad esempio le questioni intorno ai miracoli e alla possibilità che Dio possa compierli. In Tommaso ad esempio: Contra Gentiles, III, 100-101; Q. disp., De potentia, q. 6, a. 1-2; Summa theologiae, Iaㅡ, q. 105, a. 6-7. 
me si vede, è utilizzato come argomentazione volta a giustificare l'equivalenza tra il potere di Dio e quello della natura, ma in altri casi, emblematici per l'epoca medievale, assumerà una forma ben diversa. Pier Damiani, ad esempio, è attento a distinguere a chi sia impossibile e a chi no modificare il passato. È vero, secondo lui, che in natura non può avvenire che ciò che è accaduto non sia accaduto, ma è scorretto attribuire questa impossibilità anche a Dio. L'intero trattato sull'onnipotenza divina di Pier Damiani si origina in effetti proprio da questa problematica: se a Dio sia possibile o meno ripristinare la verginità di una donna una volta che è stata perduta, il che evidentemente chiama in causa i limiti del potere naturale ed eventualmente del potere divino. Un'affermazione di san Girolamo, il quale ha in merito parere negativo (Epistola XXII, ad Eustochium, 5; PL 22, 397), funge da avviamento per l'intera discussione che, verso la sua conclusione, vuole proprio sottolineare come l'onnipotenza divina sfugga tanto alla logica presuntuosa dei dialettici, quanto ad una sua riduzione a ciò che è possibile in natura, mostrando infine come essa sia capace di realizzare ciò che è ritenuto impossibile per entrambi, vale a dire la modificazione del passato (De div. omnip., 15; PL 145, 620 B).

Agostino dal canto suo dopo aver mostrato, come abbiamo visto, in che senso si possa dire che Dio operi contro natura, deve difendere una posizione che pare opposta a quella del Damiani, ossia deve difendere l'onnipotenza divina dall'accusa di non essere tale a causa del fatto che, secondo lui, Dio non possa modificare il passato. In accordo col Damiani cioè, Agostino ritiene che Dio sia onnipotente, ma differentemente da quest'ultimo, sostiene che lo sia pur non potendo modificare il passato (c. Faust., XXVI, 5; PL 42, 481). Anzi, potremmo dire che per Agostino, come per altri, Dio è onnipotente proprio perché non può rendere non accaduto ciò che è accaduto. ${ }^{6}$ Su questa stessa linea sono poi le posizioni di Tommaso d'Aquino e Bonaventura, le quali concordano nel ritenere che Dio non possa modificare il passato pur essendo onnipotente. Questi due pensatori però, sfruttano differentemente questa tesi, in diverse occasioni rendono l'impossibilità che Dio possa modificare il passato un'argomentazione contro la tesi che vogliono difendere, per poi utilizzare una serie di distinzioni per precisare la reale portata di questa impossibilità. Ad esempio, sostenendo la posizione di quello che potremmo definire un immaginario seguace di Plinio, argomentano che Dio non possa fare ciò che è impossibile alla natura visto che, come la natura, Dio non può modificare il passato; successivamente, però, rispondono a questa obbiezione distinguendo tra ciò che è impossibile soltanto alla natura e ciò che è impossibile tanto alla natura quanto a Dio (Bo-

6 Si veda ad esempio la posizione molto simile espressa da Anselmo d'Aosta: Proslogion, c. 7. 
naventura da Bagnoregio, Sent. I, dist. 42, q. 3; Tommaso d'Aquino, Sent. I, dist. 42, q. 2, a. 2; Q. disp., De potentia, q.1, a. 3). L'impossibilità di modificare il passato è un'impossibilità per sé, ossia qualcosa di contraddittorio e Dio, per Tommaso come per Bonaventura, non fa ciò che implica contraddizione. Per questi due autori rimane dunque ferma la differenza di potere tra Dio e la natura nonostante entrambi non possano modificare il passato, il loro contributo, anzi, risiede proprio nel mostrare come questa differenza permanga nonostante questa impossibilità condivisa. Si potrebbe dire che il loro non sia altro che un modo per approfondire e precisare la posizione agostiniana mostrando come, differentemente dal Damiani, si possa difendere l'onnipotenza divina e la sua non sovrapponibilità con il potere della natura pur sostenendo l'immutabilità del passato.

Che vi sia del resto una così grande varietà di modi di affrontare questa problematica e che essa possa essere sfruttata per sostenere tesi così diverse non deve sorprendere eccessivamente. Tutto ciò non fa che mostrare la varietà di posizioni in gioco e la diversità di argomentazioni usate per sostenerle. Le differenze finora esaminate non devono però farci dimenticare le motivazioni profonde che le fanno scaturire.

\section{Conclusione}

Può l'immutabilità del passato fungere da garanzia per uno svolgimento ordinato e regolato del corso della natura? Per un autore come Plinio essa contribuisce a fare anche qualcosa in più, pertiene a quel tipo di considerazioni che ci assicurano che Dio non solo non oltrepasserà i limiti dell'ordine naturale, ma soprattutto che in fondo Dio coincide con essi. Negli autori medievali da noi esaminati e che riteniamo comunque emblematici di una comunità di pensiero ben più vasta, non è così. Sia che il passato possa essere modificato da Dio, sia che non lo possa, il potere divino e la sua essenza non possono essere fatti coincidere con quelli naturali. Per un autore come Pier Damiani questo è palese, non è certo la struttura del passato a rappresentare un limite per l'onnipotenza divina. Per autori come Agostino, Bonaventura e Tommaso, invece, la conclusione che bisogna trarre è a nostro avviso più sottile e forse più interessante. L'immutabilità del passato non è una struttura tale da poter coincidere simpliciter con l'ordine naturale, essa è piuttosto una di quelle strutture ontologiche che basandosi sul principio di non contraddizione contribuiscono a rendere l'essenza della natura quella che è e che pertanto non pertengono semplicemente a ciò che, come direbbe Agostino, riguarda l'ordine a noi noto e consueto della natura, quanto piuttosto alla somma legge di natura contro cui Dio non opera nulla, in quanto contra se ipsum non facit. 


\section{Bibliografia}

Boulnois, Olivier (éd.) (1994). La puissance et son ombre. De Pierre Lombard à Luther. Parigi: Aubier.

Canziani, Guido et al. (a cura di) (2000). Potentia Dei. L'onnipotenza divina nel pensiero dei secoli XVI e XVII. Milano: Franco Angeli.

Kennedy, Leonard Anthony (1989). «The Fifteenth Century and Divine Absolute Power». Vivarium 17, 125-52.

Papineau, David (2016). s.v. «Naturalism». Zalta, Edward N. (ed.), The Stanford Encyclopedia of Philosophy (Winter 2016 Edition). URL https://plato.stanford.edu/archives/win2016/entries/naturalism/ (2018-11-11). 


\title{
Descartes aux limites du naturalisme "La force qu'a l'âme de mouvoir le corps"
}

\section{Denis Kambouchner}

Université Paris 1 Panthéon-Sorbonne, France

\begin{abstract}
In order to appreciate the distance between the Cartesian theory of man and a naturalistic programme, it is necessary to ask what exactly Descartes means by "the soul's power to move the body". A precise examination of the Cartesian texts, especially the Treatise on Man and The Passions of the Soul, will lead to the exclusion of any direct action of the soul on the body. All the action of the soul goes through the formation of certain images in the brain, which determine certain flows of animal spirits, and as for the passions, the effectiveness of this action is mainly a matter of habit. The spontaneity of thought does not preclude considering the 'force of the soul' as associated with the 'disposition of the brain'. Conversely, nothing in the Cartesian texts allows us to eliminate this spontaneity where we experience it.
\end{abstract}

Keywords Cartesianism. Dualism. Soul and body unity. Will.

Sommaire 1 Introduction. - 2 Une notion émergente. - 3 L'action de l'âme : mouvement ou imagination? - 4 Force, habitude, disposition. - 5 La volonté dans le corps?

\section{Introduction}

Au premier abord, rien n'est plus éloigné du naturalisme que ce qu'on appelle le «dualisme cartésien » avec ses propositions caractéristiques. L'âme humaine, pure chose qui pense, peut subsister sans un corps auquel elle soit jointe. Pour penser à elle-même ainsi qu'aux « choses immatérielles et métaphysiques », le corps ne lui est d'aucune utilité. Outre un entendement

\section{Philosophica 4}

e-ISSN 2610-8925 | ISSN 2610-8933

ISBN [ebook] 978-88-6969-325-0 | ISBN [print] 978-88-6969-326-7 
tout à fait distinct de l'imagination, elle possède une volonté qui est « tellement libre de sa nature, qu'elle ne peut jamais être contrainte » (Les Passions de l'âme [ci-après Passions], art. 41). L'usage du libre arbitre, qui ne fait qu'un avec cette volonté, nous rend du reste « en quelque façon semblables à Dieu en nous faisant maîtres de nousmêmes » (art. 152), et "semble nous exempter de lui être sujets ». ${ }^{1}$ Aussi bien l'âme humaine a-t-elle la force de mouvoir le corps auquel elle est jointe, selon que sa volonté se porte vers tel ou tel but pratique. Nous voilà bien loin de la condition des "animaux dépourvus de raison », dont la vie est réglée tout entière par la « disposition de leurs organes » (Discours de la méthode, 5e partie, AT VI, 57-9).

Ce tableau est connu. Il mérite pourtant d'être sinon remis en question, du moins nuancé, tout particulièrement à partir d'un examen précis de ce que Descartes appelle « la force qu'a l'âme de mouvoir le corps ", notion dont on peut s'étonner qu'elle ait été si peu interrogée. Il résultera de cet examen que si en effet Descartes a refusé toute réduction du comportement humain, tant pratique qu'intellectuel, à un enchaînement mécanique semblable à des actions des animaux, la solidarité entre les actions de l'âme humaine et les dispositions du corps s'étend toutefois assez nettement plus loin qu'on ne l'admet d'ordinaire. $^{2}$

\section{Une notion émergente}

La «force qu'a l'âme de mouvoir le corps » est une notion dont l'émergence dans les textes cartésiens a été très progressive. On n'en trouve, par exemple, aucune trace dans les Regulœe, et cela, bien que l'esprit humain y soit caractérisé comme le sujet ou le siège d'une certaine force, la " force connaissante », vis cognoscens (Règle XII, AT X, 415) : mais c'est que le corps humain en tant que tel est absent de ce traité, lequel évoque, tout au plus, le pouvoir qu'a l'esprit de faire que de nouvelles images se forment dans cette « véritable partie du corps » qui est le siège de l'imagination.

Dans la chronologie des textes cartésiens qui nous ont été conservés, l'histoire de la « force de l'âme » commence avec le Traité de l'Homme de 1632-1633. Elle n'y est cependant évoquée qu'en passant : à propos de la petite glande notée $H$, qui est suspendue au milieu du cerveau, et par laquelle les esprits animaux, qui sont les

1 À Christine de Suède, 20 novembre 1647. Édité par Adam et Tannery [ci-après AT] vol. V, 85, 15-16.

2 J'ai déjà abordé cette question dans Kambouchner (2015, 147-56), ainsi que dans Kambouchner (2017, 177-88). La présente étude reprend un certain nombre d'éléments de ces contributions pour les développer et les compléter. 
"parties les plus subtiles du sang », s'écoulent sans cesse dans ses concavités, Descartes indique qu'« il y a deux causes principales, sans compter la force de l'âme, que je mettrai ci-après, qui peuvent la faire ainsi mouvoir [sc. : la glande H] » (L'Homme, AT XI, 180). Le Traité se conclut toutefois, du moins sa première partie, avant que l'auteur y revienne. En revanche, la lettre à Élisabeth du 21 mai 1643 fera de la notion de cette force de l'âme une part, ou une suite, de la notion « simple et primitive » que nous avons de l'union de l'âme et du corps :

Je considère qu'il y a en nous certaines notions primitives, qui sont comme des originaux, sur le patron desquels nous formons toutes nos autres connaissances. Et il n'y a que fort peu de telles notions ; car, après les plus générales [...], nous n'avons, pour le corps en particulier, que la notion de l'extension, de laquelle suivent celles de la figure et du mouvement ; et pour l'âme seule, nous n'avons que celle de la pensée, en laquelle sont comprises les perceptions de l'entendement et les inclinations de la volonté ; enfin, pour l'âme et le corps ensemble, nous n'avons que celle de leur union, de laquelle dépend celle de la force qu'a l'âme de mouvoir le corps. (AT III, 665)

Cette force sera encore évoquée deux ans et demi plus tard dans la lettre du 6 octobre 1645 :

En l'homme, [...] l'âme [...] a quelque force pour changer les impressions qui sont dans le cerveau. (AT IV, 310)

Et Les Passions de l'âme reprendront le même principe : la « force de l'âme » s'y trouve évoquée à l'article 36 ("Exemple de la façon que les passions sont excitées en l'âme »), lequel est précédé d'un énoncé général à l'article 34 :

La petite glande qui est le principal siège de l'âme est tellement suspendue entre les cavités qui contiennent ces esprits, qu'elle peut être mue par eux en autant de diverses façons qu'il y a de diversités sensibles dans les objets ; mais [...] elle peut être aussi diversement mue par l'âme. (Passions, art. 36)

Notons encore la fréquente intervention de ce principe dans la suite de la première partie du traité, par exemple à l'article 43 :

Quand on veut imaginer quelque chose qu'on n'a jamais vue, cette volonté a la force de faire que la glande se meut en la façon qui est requise pour pousser les esprits vers les pores du cerveau par l'ouverture desquels cette chose peut être représentée. (Passions, art. 43; italiques ajoutées) 
Dans le contexte des Passions de l'âme, où il s'agit de la relation de l'âme à ses passions, cette notion de «force de l'âme » comporte une dimension morale assez marquée, qu'elle n'avait pas dans L'Homme. Une question sera de savoir quel rapport cette force morale entretient avec l'aspect purement fonctionnel (psychophysiologique) de la notion, à quoi correspondra plutôt le seul mot latin vis. Mais déjà, l'évocation de cette vis est apparue à quelques-uns des premiers lecteurs de Descartes et à plusieurs penseurs de la génération suivante comme une sorte de scandale. Avant que Spinoza, sur la base de la traduction latine des Passions de l'âme (Passiones animœe, 1650), ne se livre dans la préface de la cinquième partie de son Éthique à une charge un peu trop brutale (« Je voudrais bien savoir combien de degrés de mouvement l'esprit peut attribuer à cette petite glande pinéale », etc.), la question a été posée par Gassendi dans les Cinquièmes Objections (VI, 4, AT VII, 341), puis, avec une parfaite netteté, par la princesse Elisabeth, notamment dans sa réponse à Descartes, datée du 20 juin 1643:

J'avoue qu'il me serait plus facile de concéder la matière et l'extension à l'âme, que la capacité de mouvoir un corps et d'en être ému, à un être immatériel. Car, si le premier se faisait par information, il faudrait que les esprits [animaux], qui font le mouvement, fussent intelligents, ce que vous n'accordez à rien de corporel. Et encore qu'en vos Méditations Métaphysiques, vous montrez la possibilité du second, il est pourtant très difficile à comprendre qu'une âme, comme vous l'avez décrite, après avoir eu la faculté et l'habitude de bien raisonner, peut perdre tout cela par quelques vapeurs, et que, pouvant subsister sans le corps et n'ayant rien de commun avec lui, elle en soit tellement régie. (À Élisabeth, 28 juin 1643, AT III, 685)

Pourtant, Descartes a maintenu ce point - particulièrement dans le Traité de 1649, de fait son ultime ouvrage - sans en donner, ni à Élisabeth, ni apparemment à quiconque, ce qui aurait été reçu comme une explication en bonne et due forme, et sans même préciser ce qui change avec l'action de l'âme dans le mouvement ou la position de la glande pinéale.

Faut-il parler de désinvolture ? Il n'y a guère de place pour cela en ces matières. D’embarras ? Mais celui-ci serait étrange, s'agissant d'un point absolument central de l'anthropologie cartésienne. Le philosophe aura plutôt estimé sincèrement que la question ne se posait pas. Il convient de déterminer pour quelles raisons. 


\section{L'action de l'âme : mouvement ou imagination ?}

Le premier point à remarquer est que Descartes parle toujours de la «force qu'a l'âme de mouvoir le corps » sur un mode très objectif et presque physicaliste. Dans la lettre à Élisabeth du 21 mai 1643, « la force qu'a l'âme de mouvoir le corps » est en fait mise sur le même plan que la force qu'a le corps " d'agir sur l'âme, en causant ses sentiments et ses passions » (AT III, 665). Dans celle du 6 octobre 1645, on lit aussi que l'âme a « quelque force pour changer les impressions qui sont dans le cerveau, comme réciproquement ces impressions ont la force d'exciter en l'âme des pensées qui ne dépendent point de sa volonté » (AT IV, 310; italiques ajoutées).

Il s'agit donc d'une force réciproque, à laquelle il faut reconnaître un caractère structurel : l'union de l'âme et du corps ne signifiera proprement rien si l'âme et le corps n'ont pas « quelque force pour » provoquer l'une dans l'autre certaines modifications. L'expression : « avoir quelque force pour... » doit d'ailleurs être détachée de la représentation d'une intention; nous la retrouvons en effet dans un contexte purement physique, dans la seconde partie des Principes de la philosophie, article 43 :

Un corps qui est joint à un autre corps a quelque force pour empêcher qu'il n'en soit séparé ; [...] lorsqu'il en est séparé, il a quelque force pour empêcher qu'il ne lui soit joint ; et aussi [...], lorsqu'il est en repos, il a de la force pour demeurer en ce repos et pour résister à tout ce qui pourrait le faire changer. (Principes de la philosophie, art. 43; italiques ajoutées)

En somme, réduite à sa plus simple signification (et la plus transcendantale), l'expression : «A a quelque force pour agir sur B » veut dire seulement qu'il existe une relation régulière entre certaines modifications de A et certaines modifications de B, relation telle qu'il y a un sens à désigner la modification de $\mathrm{A}$, donc en un sens $\mathrm{A}$ même, comme la cause principale de cette modification en B. La « force » de A est quantifiable si et seulement si est quantifiable la modification induite en B. Autrement, elle se ramène à une simple propriété causale (ainsi pour la «force qu'a le sel de garder les choses de se corrompre », À Reneri pour Pollot, avril ou mai 1638, AT II, 44). Force, pouvoir, vertu sont à cet égard des termes largement équivalents.

Pour ce qui est de l'exercice d'une certaine vis par l'âme, on peut en parler à chaque fois qu'une certaine intention ou détermination de la volonté induit ou semble induire dans le corps un certain mouvement ou un processus physique spécifique. C'est le cas dans le mouvement volontaire, dans le combat de l'âme contre sa passion présente, mais aussi, déjà, avec le mode volontaire de l'imagination et de la remémoration. Dans ce dernier cas, le processus physique est 
purement interne au cerveau ; mais dans tous les cas, le fait décisif est un certain mouvement de la glande pinéale qui est le «principal siège de l'âme » (Passions, artt. 31-32).

C'est à ce mouvement seul qu'a tenu le scandale. Ce qui a choqué de nombreux lecteurs de Descartes - même en suggérant, comme Leibniz, que la quantité totale de mouvement ne change pas, mais seulement la direction -, c'est que l'âme ait reçu le pouvoir de faire que la glande, au milieu du cerveau, se penche d'un côté déterminé, de manière à induire un mouvement déterminé, ou à inaugurer un processus déterminé, avec un résultat déterminé dans le corps, ou hors de lui, ou éventuellement dans l'âme elle-même (dans ses propres perceptions). À l'article 47 des Passions de l'âme, Descartes va jusqu'à dire :

La petite glande qui est au milieu du cerveau pouvant être poussée d'un côté par l'âme, et de l'autre par les esprits animaux, qui ne sont que des corps [...], il arrive souvent que ces deux impulsions sont contraires, et que la plus forte empêche l'effet de l'autre. (Passions, art. 47)

On peut alors parler d'une sorte de combat « entre l'effort dont les esprits poussent la glande pour causer en l'âme le désir de quelque chose, et celui dont l'âme la repousse par la volonté qu'elle a de fuir la même chose » (Passions, art. 47).

C'est là un langage vraiment surprenant et qui conduit en effet à attribuer à l'âme, à titre direct, un certain effort qui est supposé être quantifiable (plus fort ou plus faible que l'effort physique que les esprits animaux exercent sur la glande).

Cependant, il faut contrebalancer ou même mitiger cette version des choses avec ce qu'on lisait, un peu plus haut, à l'article 44 :

Ce n'est pas toujours la volonté d'exciter en nous quelque mouvement, ou quelque autre effet, qui peut faire que nous l'excitons : mais cela change selon que la nature ou l'habitude ont diversement joint chaque mouvement de la glande à chaque pensée. (Passions, art. 44; italiques ajoutées)

Nous apprenons ici que l'âme n'applique jamais directement une certaine force ou un certain " effort » à la petite glande. La force appliquée à la glande appartient bien plutôt à l'objet de sa pensée. Et c'est ce schème qu'on retrouve un peu plus loin dans un passage capital de l'article 47. Qu'arrive-t-il en effet quand l'âme entreprend de combattre sa passion présente?

La volonté n'ayant pas le pouvoir d'exciter directement les passions, ainsi qu'il a déjà été dit, elle est contrainte d'user d'industrie, et de 
s'appliquer à considérer successivement diverses choses dont, s'il arrive que l'une ait la force de changer pour un moment le cours des esprits [animaux], il peut arriver que celle qui suit ne l'a pas, et qu'ils le reprennent aussitôt après, à cause que la disposition qui a précédé dans les nerfs, dans le cœur et dans le sang n'est pas changée : ce qui fait que l'âme se sent poussée presque en même temps à désirer et ne désirer pas une même chose. (Passions, art. 47)

L'action de l'âme sur le cours des esprits animaux n'implique pas seulement la formation d'une certaine volonté ou volition: elle implique, aussi et surtout, l'appel à une imagination qui est la seule chose capable d'agir de manière directe sur les esprits. C'est la formation d'une impression ou image dans le cerveau qui est ici le phénomène ou l'élément décisif, et non un mouvement considéré simplement comme tel. Et il n'y a pas d'indice que cette condition admette des exceptions.

Les conditions physiologiques de cette imagination demandent maintenant à être précisées. Pour que l'âme soit dite imaginer quelque chose, il faut qu'une image se forme sur la petite glande où elle a son "siège principal " ; mais il est tout aussi indispensable qu'une semblable image se forme dans ce que Descartes appelle la «superficie intérieure du cerveau » (les parois des concavités ventriculaires au milieu desquelles la petite glande est suspendue). Et d'après le Traité de l'Homme, il est clair que l'une des images ne se forme pas sans l'autre ; car dans ce traité, les esprits animaux sont présentés comme s'écoulant dans le cerveau depuis la glande ellemême, qu'il faut se représenter " comme une source fort abondante d'où [les esprits] coulent en même temps de tous côtés dans les concavités du cerveau » (cf. L'Homme, AT XI, 130, 7-9). L'image formée sur la glande est donc constituée de points déterminés par lesquels les esprits en sortent (autrement dit, par le mouvement des esprits sortant de la glande en des points déterminés) ; mais ce ne peut être le cas sans que s'ouvrent, face à la glande, certains pores de la superficie intérieure du cerveau, vers lesquels se dirige plus particulièrement le flux des esprits. C'est là une condition tout à fait expresse :

Les esprits qui tendent à entrer dans chacun des petits tuyaux 2, 4,6 , et semblables [de la substance du cerveau], ne viennent pas indifféremment de tous les points qui sont en la superficie de la glande $\mathrm{H}$, mais seulement de quelqu'un en particulier. (L'Homme, AT XI, 175, 1l. 17-22) 
Ainsi,

ce sont ceux qui viennent, par exemple, du point $a$ de cette superficie, qui tendent à entrer dans le tuyau 2, et ceux des points $b$ et $c$, qui tendent à entrer dans les tuyaux 4 et 6 , et ainsi des autres. En sorte qu'au même instant que l'ouverture de ces tuyaux devient plus grande, les esprits commencent à sortir plus librement et plus vite qu'ils ne faisaient auparavant, par les endroits de cette glande qui les regardent. Et que, comme les diverses façons dont les tuyaux 2, 4, 6, sont ouverts, tracent une figure qui se rapporte à celle de l'objet $\mathrm{ABC}$, sur la superficie intérieure du cerveau : ainsi celle dont les esprits sortent des points $a, b, c$, la tracent sur la superficie de cette glande. (L'Homme, AT XI, 175, 22; 176, 8)

La question qui s'impose naturellement est celle de savoir si ce sont les esprits animaux provenant de certains points de la glande qui ouvrent les pores correspondants (entrées des «tuyaux » de sa substance, dont beaucoup sont les origines des nerfs), ou si c'est l'ouverture de ces pores qui détermine l'afflux des esprits, et avec lui le mouvement de la glande. Pour les impressions des sens, il est parfaitement clair que l'image ainsi formée se transporte vers la glande depuis la superficie intérieure du cerveau. Pour celles de l'imagination, il pourra sembler que ce soit l'inverse, si ces imaginations procèdent d'une certaine volonté. Pourtant, en aucun cas les esprits animaux qui proviennent de la glande ne peuvent ouvrir des pores du cerveau qui (a) ne feraient pas face à cette glande, et (b) ne seraient pas disposés (prédisposés) à être ouverts. La tendance des esprits à entrer dans un certain «tuyau » ne s'entend pas sans la tendance de ce «tuyau » à les attirer. Nous avons donc ici affaire à une causalité toujours complexe, qui met en jeu sur le plan physiologique non du tout la glande pinéale toute seule, mais le tout de ce que Descartes appelle, dans Les Passions de l'âme, la « disposition du cerveau ». ${ }^{4}$ Et s'il existe un conflit des imaginations, tel que l'admet l'article 47 du traité, celui-ci a d'emblée une dimension intracérébrale et topographique (l'expression dudit article est à cet égard très abrégée).

4 Dans Les Passions de l'âme, l'expression ne figure qu'une fois, à l'article 50 et dernier de la première partie (AT XI, 369, 22) : «Lorsqu'on rencontre inopinément quelque chose de fort sale en une viande qu'on mange avec appétit, la surprise de cette rencontre peut tellement changer la disposition du cerveau, qu'on ne pourra plus voir par après de telle viande qu'avec horreur, au lieu qu'on la mangeait auparavant avec plaisir ». Le concept en intervient toutefois aux articles 36 et 39, cités ci-après. 


\section{Force, habitude, disposition}

Admettons que toute la force de l'âme à l'égard du corps, dans la situation qui nous intéresse, passe par un acte d'imagination (avec sa dimension physique et sa réalité cérébrale) : cette imagination n'est certes pas formée sans une certaine volonté. Mais un autre facteur sera à prendre en compte, à savoir la coutume ou l'habitude. Dans quels cas l'âme aura-t-elle le plus de chances d'obtenir le résultat cherché, à savoir d'éteindre ou de neutraliser la passion indésirable? Sans doute faut-il dire : plus l'idée, la conception ou la représentation qu'elle oppose à cette passion lui sera familière, plus grandes seront ses chances de vaincre cette passion. La force de l'idée, puisqu'il y a un sens à en parler en contexte cartésien et non seulement spinoziste, est la force d'une certaine conviction, qui en tant que telle a besoin d'avoir été antérieurement cultivée, nourrie par l'esprit. C'est la force d'une habitude, et l'on pourrait dire des idées les plus puissantes que ce sont celles qui occupent la plus grande place dans l'esprit.

C'est là sans doute ce que Descartes a en vue à l'article 48 des Passions de l'âme, lorsqu'il parle des " jugements fermes et déterminés touchant la connaissance du bien et du mal » d'après lesquels les âmes les plus fortes ont résolu de conduire les actions de leur vie. Si ces jugements constituent « les propres armes » de la volonté, c'est précisément - quelle que soit ici la part de la nature - que l'esprit se les représente et les reconnaît pour siens à répétition. Et cela n'est pas entièrement propre aux âmes les plus fortes : d'après l'article 49, celles qui sont de condition moyenne se conduisent elles aussi assez généralement d'après certains jugements, même si ceux-ci leur ont été au départ dictés par certaines passions.

Le point principal est toutefois le suivant : l'habitude ne peut pas être constituée dans l'âme sans l'être aussi dans le cerveau. Certes, dans les jugements sur le bien et le mal, il entre une part de pur entendement; mais la matière de ces jugements est bien loin d'être purement intellectuelle, et même si les choses dont il s'agit ne sont pas directement des objets d'imagination, elles sont impossibles à détacher de l'expérience de certaines émotions, et elles prêtent par excellence à une figuration symbolique (les deux conditions étant sans doute liées). Ainsi, les conceptions dont il s'agit ne peuvent avoir une telle place dans la pensée sans que certaines imaginations correspondantes soient fermement établies dans le cerveau.

C'est ici que nous rencontrons la "disposition du cerveau», c'est-à-dire le système de connexions virtuelles qui fait que telle impression des sens réveille telle représentation et se trouve suivie de telle réaction motrice. La question est : y a-t-il une relation, et laquelle, entre la force de l'âme et cette « disposition du cerveau » ? On lit à l'article 36, avec l'exemple de l'animal dont le surgissement cause une passion violente : 
Si [la figure de cet animal] est fort étrange et fort effroyable, cela excite en l'âme la passion de la crainte, et ensuite celle de la hardiesse ou celle de l'épouvante, selon le divers tempérament du corps ou la force de l'âme, et selon qu'on s'est auparavant garanti par la défense ou par la fuite contre les choses nuisibles auxquelles l'impression présente a du rapport. Car cela rend le cerveau tellement disposé en quelques hommes, que les esprits [animaux] se rendent de là partie dans les nerfs qui servent à tourner le dos et à remuer les jambes pour s'enfuir, etc. (AT XI, 356, 10-23; italique ajoutée)

Qu'est-ce exactement qui rend le cerveau disposé de telle manière ? Le texte de Descartes n'est pas tout à fait clair, du fait d'une répétition malencontreuse (« cela excite... car cela rend... »). Mais, sur le fond, il ne peut pas y avoir de doute : ce qui dispose le cerveau de telle ou telle manière n'est pas la figure de l'animal ; c'est l'ensemble des facteurs antérieurs qui doivent ici entrer en jeu. On lit du reste un peu plus loin (article 39) ceci qui est tout à fait explicite :

La même impression que la présence d'un objet effroyable fait sur la glande, et qui cause la peur en quelques hommes, peut exciter en d'autres le courage et la hardiesse : dont la raison est que tous les cerveaux ne sont pas disposés en même façon, et que le même mouvement de la glande qui en quelques-uns excite la peur fait dans les autres que les esprits entre dans les pores du cerveau qui les conduisent, etc. (AT XI, 358, 18-25; italique ajoutée)

Dans ces conditions, la «force de l'âme » peut-elle être un facteur indépendant? L'article 39 la fait plutôt apparaître comme un facteur intégré à la "disposition du cerveau ». Cela signifiera qu'en règle générale l'action de l'âme se tient dans les limites de cette disposition, et qu'elle a très généralement un caractère habituel, avec des exceptions qu'il faudra soumettre à discussion. Dans les cas exceptionnels, s'il faut en admettre, est-ce en effet l'esprit qui se libère de sa propre coutume, ou bien le corps qui se trouve dans une autre disposition que l'ordinaire, ou bien encore le fait est-il que des circonstances particulières rendent la reproduction d'une habitude impossible ?

Il convient cependant de mesurer les implications d'une telle proposition, qui semble nous diriger droit vers une forme de naturalisme, avec une entière dissolution de l'action de l'âme, du moins sur son versant pratique (à distinguer des œuvres de pure réflexion), dans une certaine économie comportementale. Se pourraitil que le volontaire, chez Descartes, se résolve dans l'habituel, et que ce à quoi l'âme elle-même tend ou ce qu'elle entend faire prévaloir en telle ou telle « rencontre » soit intégralement prédéterminé dans la constitution du composé humain? 


\section{$5 \quad$ La volonté dans le corps ?}

Il existe sur ce sujet un texte remarquable, que Desmond M. Clarke (2003, 137) avait dûment relevé, et dont Frédéric de Buzon a récemment repris l'étude (de Buzon, Cassan, Kambouchner 2015, 31118): il s'agit de la préface du traité inachevé de 1648, La Description $d u$ corps humain, texte qui porte d'abord sur les mouvements involontaires en tant qu'ils marquent les limites de l'efficacité de l'âme. Descartes écrit :

Nous pouvons voir [...] que lorsque quelques parties de notre corps sont offensées, par exemple, quand un nerf est piqué, cela fait qu'elles n'obéissent plus à notre volonté, ainsi qu'elles avaient de coutume, et même que souvent elles ont des mouvements de convulsion, qui lui sont contraires. Ce qui montre que l'âme ne peut exciter aucun mouvement dans le corps, si ce n'est que tous les organes corporels qui sont requis à ce mouvement soient bien disposés ; mais que, tout au contraire, lorsque le corps a tous ses organes disposés à quelque mouvement, il n’a pas besoin de l'âme pour le produire. (AT XI, 224-5)

Rien là qui ne soit conforme à d'autres développements cartésiens, de même que la suite de la phrase :

et que par conséquent, tous les mouvements que nous n'expérimentons point dépendre de notre pensée, ne doivent pas être attribués à l'âme, mais à la seule disposition des organes. (AT XI, 224-5)

Mais il y a une ultime proposition, beaucoup plus étonnante :

et que même [i.e.: ce qui montre même que] les mouvements qu'on nomme volontaires procèdent principalement de cette disposition des organes, puisqu'ils ne peuvent être excités sans elle, quelque volonté que nous en ayons, bien que ce soit l'âme qui les détermine. (AT XI, 224-5)

L'étonnant, ici, tient à une sorte de renversement dans la primauté causale. Les mouvements qu'on nomme volontaires, écrit Descartes, ne peuvent être excités sans une certaine disposition des organes. Sans doute : mais le «ce sans quoi » ne suffit pas, en principe, à désigner cette disposition comme la cause principale de ces mouvements. Or c'est bien là le pas franchi : ces mouvements, écrit encore Descartes, " procèdent principalement » de cette disposition, et l'âme (qu'on croirait être, avec sa volonté, leur cause principale, ou du moins la plus élevée) ne fait que les « déterminer ». "La disposition des 
organes », écrit Frédéric de Buzon, " est une condition nécessaire [de ces mouvements], mais elle paraît aussi une condition quasi suffisante » (de Buzon, Cassan, Kambouchner 2015, 312).

Pourquoi Descartes va-t-il jusqu'à présenter les choses ainsi ? Cela restera difficile à indiquer. Quoi qu'il en soit, ce qui vaut pour des mouvements volontaires simples et caractérisés (par exemple, lever le bras) doit valoir également pour toute action que l'âme voudra induire dans le corps, y compris l'extinction d'une passion déterminée.

Que veut dire alors que l'âme " détermine » ces mouvements ? Il n'y aura guère à cette question que deux réponses : ou bien l'âme choisit entre des possibles physiologiques, et peut-être entre deux tendances prédéterminées dans le corps; elle exerce alors sur le corps une action aussi petite que l'on voudra, puisque nous savons que chez Descartes une petite action dans un système mécanique, par exemple dans la répartition cérébrale des esprits animaux, peut grandement changer l'effet global. Ou bien l'âme se contente d'élire pour elle-même ou pour le composé, dans une simple pensée d'assentiment ou d'authentification, ce qui constitue à un moment donné la tendance prévalente du corps (cerveau inclus bien sûr) ou l'objet de cette tendance.

La première hypothèse est celle que privilégie notre étude récente ; elle est conforme à certains schémas cartésiens (notamment le système hydraulique et le fontainier du Traité de l'Homme) (cf. AT XI, 121 et 130-1), et elle a l'avantage de réduire la réalité physique de la force de l'âme à une quantité infinitésimale. Elle a toutefois l'inconvénient de laisser subsister le principe de cette quantité physique, dans des conditions physiologiquement peu claires.

La seconde hypothèse a l'avantage de faire disparaître le problème physique, mais elle ôte à l'âme toute action véritable sur le corps, et cela, selon un schème moins occasionnaliste que paralléliste ou d'harmonie préétablie; elle donne au verbe « déterminer » un sens exceptionnellement faible (en contexte cartésien), et laisse paradoxalement subsister (pour autant que le propos cartésien peut s'y étendre) le problème du combat contre la passion présente, avec cette fois le principe d'une division de la disposition du cerveau, ou encore d'une disposition des organes qui contrarierait une autre disposition des organes.

Entre les deux hypothèses, il n'est pas sûr qu'on puisse trancher. Non seulement le texte de la Description du corps humain ne dit pas un mot du cerveau ni de ce qui s'y passe en cas de mouvement volontaire, mais la représentation cartésienne du cerveau, quelque étayage qu'elle ait cherché dans l'observation anatomique, reste d'essence très schématique et peu propre à rendre compte de processus complexes : ainsi l'explication du mécanisme du ressouvenir, à l'article 42 des Passions de l'âme, reste-t-elle très peu précise : 
Lorsque l'âme veut se souvenir de quelque chose, cette volonté fait que la glande, se penchant successivement vers divers côtés, pousse les esprits vers divers endroits du cerveau, jusques à ce qu'ils rencontrent celui où sont les traces que l'objet dont on veut se souvenir y a laissées. [...] Au moyen de quoi ils excitent un mouvement particulier en la glande, lequel représente à l'âme le même objet, et lui fait connaître qu'il est celui duquel elle voulait se souvenir. (Passions, art. 42)

Sous ce rapport, revenons à l'idée que l'action de l'âme dans le corps consiste exclusivement, à titre immédiat, en un acte d'imagination. Que dira-t-on du processus ou de l'événement cérébral immédiatement lié à l'acte d'imaginer ? Pour reprendre l'expression de la Description du corps humain, est-ce du corps (avec la disposition du cerveau) ou de l'âme (avec sa volonté) que l'imagination « dépend principalement » ? C'est à cette question qu'il faut sans doute renoncer à répondre. Les éléments de cette imagination doivent bien sûr être présents dans le cerveau. Cependant, l'effort pour imaginer peut-il relever du corps luimême ? Cela se laisse difficilement concevoir.

En réalité, sauf dans les cas les plus simples de la sensation et, pour partie, du ressouvenir, nous ne savons pas du tout comment une image se forme dans le cerveau cartésien. Ce cerveau est propre à la transmission et à la réactivation d'impressions d'objets (lesquelles sont aussi, comme Spinoza le comprendra, des affections du corps et des traces de ces affections). En revanche, il n'est pas propre à retenir les traces de tous les éléments de nos pensées, et ne permet en aucune manière de se figurer l'équivalent ou la réalité physique d'un processus de pensée tant soit peu complexe, ni même de la plus simple réflexion. Il faut enregistrer cette limitation de principe : l'impossibilité d'imaginer une forme cérébrale pour ce que le Hobbes du Leviathan (ch. III) nommera le «discours mental », et la conviction que les différences proprement intellectuelles (entre les pensées ou notions) sont impossibles à traduire en termes physiques, conditionnent bien évidemment la conviction cartésienne qu'un très grand nombre de nos pensées se produisent dans notre esprit sans le secours de l'imagination. Cela toutefois n'empêche pas que, pour tout ce qui se rapporte à la conduite de la vie, des structures cérébrales soient fixées, à savoir en tant que cette conduite se rapporte à des objets « qui nous importent » (Passions, art. 52): réserve faite de la part de la curiosité intellectuelle, ces objets sont en effet relativement fixés et en nombre limité, conformément à la capacité du cerveau comme organe de la mémoire. En ce sens, nonobstant l'usage du libre arbitre tel que Dieu nous l'a donné, il n'est pas faux que dans un très grand nombre de nos actions, nous soyons quasi automates ; mais il ne sera jamais concevable que nous le soyons entièrement, ni pour leur totalité. 


\section{Bibliographie}

Alanen, Lilli (2003). Descartes's Concept of Mind. Cambridge : Harvard University Press.

AT = Adam, Charles; Tannery, Paul (éds) (1897-1913). Euvres de Descartes. 11 vols. Nouvelle présentation. Paris: Vrin-CNRS.

Baker, Gordon ; Morris, Katherine J. (1996). Descartes' Dualism. London ; New York: Routledge.

Beyssade, Jean-Marie (1983). «Réflexe ou admiration. Sur les mécanismes sensori-moteurs selon Descartes ». Marion, Jean-Luc (éd.), La Passion de la raison. Hommage à Ferdinand Alquié. Paris: Presses universitaires de France, 113-30.

Bos, Erik-Jan (2017). «Descartes and Regius on the Pineal Gland and Animal Spirits, and a Letter of Regius on the True Seat of the Soul ». Gaukroger, Stephen; Wilson, Catherine (eds), Descartes and Cartesianism. Essays in Honour of Desmond Clarke. Oxford: Oxford University Press, 95-111.

de Buzon, Frédéric ; Kambouchner, Denis (2015). "L'âme avec le corps : les sens, le mouvement volontaire, les passions ». de Buzon, Frédéric ; Cassan, Élodie ; Kambouchner, Denis (éds), Lectures de Descartes. Paris : Ellipses, 279-328.

Clarke, Desmond M. (2003). Descartes's Theory of Mind. Oxford: Oxford University Press.

Kambouchner, Denis (1995). L'Homme des passions. 2 vols. Paris : Albin Michel.

Kambouchner, Denis (2008). Descartes et la philosophie morale. Paris: Hermann.

Kambouchner, Denis (2015). Descartes n'a pas dit. Paris : Les Belles-Lettres.

Kambouchner, Denis (2017). « Descartes on the Power of the Soul : A Reconsideration ». Gaukroger, Stephen; Wilson, Catherine (eds), Descartes and Cartesianism : Essays in Honour of Desmond Clarke. Oxford : Oxford University Press, 177-88.

Landucci, Sergio (2002). La Mente in Cartesio. Milano : FrancoAngeli.

McLaughlin, Peter (1993). «Descartes on Mind-Body Interaction and the Conservation of Motion ». Philosophical Review, 12, 155-82.

Rodis-Lewis, Geneviève (1990). L'Anthropologie cartésienne. Paris: Presses universitaires de France.

Roux, Sandrine (éd.) (2015). Le corps et l'esprit. Problèmes cartésiens, problèmes contemporains. Paris : Éditions des Archives contemporaines.

Rozemond, Marleen (1998). Descartes's Dualism. Cambridge (MA): Harvard University Press.

Scribano, Emanuela (2015). Macchine con la mente. Fisiologia e metafisica tra Cartesio e Spinoza. Roma : Carocci. 


\title{
La Natura e il Metodo La conoscenza come lotta per la libertà in Spinoza
}

\author{
Luigi Emilio Pischedda \\ Università Ca' Foscari Venezia, Italia; Université Paris 1 Panthéon - Sorbonne, France
}

\begin{abstract}
The naturalistic approach to knowledge, as emerges from of Quine's and Sellars' works, puts an absolute trust in the way science operates, insomuch that it suggests that philosophy should adopt its criteria and methods. This subsumption of philosophy to science is possible only reducing every discourse on their relationship to a mere question of method. This article aims to point out, by using Spinoza's thought, the possibility of an escape from this rigid dichotomy. For the Dutch philosopher the study of nature is, in fact, the occasion for a broader consideration on the possibilities of knowledge in contributing to the achievement of an authentic freedom.
\end{abstract}

Keywords Spinoza. Method. Naturalism. Political epistemology. Theory of knowledge.

Sommario 1 Introduzione. - 2 Meravigliarsi della natura: pregiudizi e uso politico dei metodi conoscitivi. - 3 Alia veritatis norma: rivedere il metodo. - 4 Conclusione.

\section{Introduzione}

Istituire un'immediata correlazione tra il pensiero di Spinoza e quella macrocategoria che, sotto il nome di 'naturalismo', ${ }^{1}$ è stata dominante all'interno della riflessione analitica, a partire dalla seconda metà del Novecento, appare come un'operazione quanto meno problematica. Certamente è possibile solo a patto di sacrificare e appiattire la trama di questioni che emergono

1 Per avere una panoramica il più possibile esaustiva si vedano, in proposito, Quine 1969; De Caro, Macarthur 2004; Sellars 2007; Laudisa, Datteri 2011; Laudisa 2014.

\section{Philosophica 4}

e-ISSN 2610-8925 | ISSN 2610-8933

ISBN [ebook] 978-88-6969-325-0 | ISBN [print] 978-88-6969-326-7 
da alcuni luoghi dell'opera di Spinoza (es. Deus sive natura, la coppia natura naturans - natura naturata). Un aspetto che già i contemporanei del filosofo desideravano scongiurare, esortando lo stesso autore a chiarire i passi più oscuri. ${ }^{2}$ D'altra parte, anche lo stesso naturalismo, nel suo affermarsi all'interno della comunità filosofica di stampo analitico, ha sviluppato una forte polisemia, andando a costituire quello che Federico Laudisa $(2014,3)$ ha definito come un «vero e proprio albero genealogico di concetti».

A margine di queste difficoltà, provare a valutare se vi siano o meno punti di tangenza tra Spinoza e il Naturalismo può essere un esercizio non banale e meno semplice del previsto. Per poterlo svolgere è perciò necessario tratteggiare brevemente i termini del confronto.

Il naturalismo è l'espressione di quell'orizzonte teorico che ripone un'assoluta fiducia nel modo di operare della scienza, tanto da suggerire alla filosofia, in quanto conoscenza filosofica, di assumerne i paradigmi di indagine. Fare ricerca in campo filosofico, significa allora essere in grado di ridurre il problema in esame alle sue basi naturali. Ciò vuol dire, riprendendo l'analisi di Laudisa, che il naturalismo:

(N1) accetta come possibili entità del mondo soltanto i tipi di cose che le teorie scientifiche pongono come oggetti effettivi della loro indagine;

(N2) ritiene che i metodi delle teorie scientifiche siano gli unici che producono autentica conoscenza;

(N3) nega all'analisi concettuale tipica della filosofia un ruolo privilegiato nella giustificazione della conoscenza stessa. (Laudisa 2014, 4)

La scienza e il metodo che da essa discende non solo costituiscono il modello di conoscenza a cui la filosofia deve richiamarsi ma, aspetto cruciale, ne definiscono il vero e proprio campo d'esistenza. L'identità stessa della filosofia è in gioco: solo ciò a cui viene riconosciuta la dignità di 'esistenza scientifica' può essere 'anche' indagato dalla filosofia. Questo approccio che determina fortemente il tipo di razionalismo insito nel naturalismo (entro tutte le sue varianti) è il frutto della sedimentazione progressiva di quell'evento fondamentale per la cultura occidentale che è stata la Rivoluzione scientifica (Laudisa 2014, 8-16). È in quell'arco di tempo, che vede la pubblicazione, prima, delle opere di Copernico, poi di Galilei ed infine di Newton,

2 Nello specifico degli argomenti che verranno presi in esame dal presente studio, non può che essere utile rifarsi alla lettera del 15 novembre 1675 che Henry Oldenburg invia a Spinoza, scrivendo: «Non posso non approvare la decisione, che mi esprimi, di voler chiarire e rendere meno duri quei punti del Trattato teologico-politico che hanno tormentato i lettori. In primo luogo, io credo, quanto lì hai espresso ambiguamente su Dio e la natura: quasi tutti pensano che tu confonda le due cose» (Ep, XXIII). 
che si costituisce una visione più unitaria del mondo naturale che rinuncia ai particolarismi delle teorie cosmo-teologiche premoderne. Questo processo avviene grazie alla concomitanza di due fattori tra loro non disgiungibili: una marcata predisposizione all'astrazionemodellizzazione e, parallelamente, una necessaria riconsiderazione del ruolo dell'esperienza attraverso la sua trasformazione in esperimento. È quanto non manca di sottolineare il grande storico della scienza Alexandre Koyré nelle sue pagine dedicate all'analisi dei lavori di Galileo:

L'esperienza, nel senso dell'esperienza bruta o dell'osservazione nel senso comune, non ha svolto alcun ruolo, se non quello di ostacolo, nella nascita della scienza classica [...]. Quanto all'esperimento - nel senso di interrogazione metodica della natura - esso presuppone sia il linguaggio nel quale porre le sue domande, sia un vocabolario che consenta di interpretare le risposte. Ora, se è in un linguaggio matematico, o più esattamente geometrico, che la scienza interroga la natura, questo linguaggio - o più esattamente la decisione di utilizzarlo, decisione che corrisponde ad un nuovo atteggiamento metafisico - non poteva essere dettato dall'esperienza che esso avrebbe condizionato. (Koyré 1976, 5; corsivi aggiunti)

Il nuovo approccio metodico allo studio dei fenomeni naturali porta la scienza moderna a ritagliarsi un proprio ruolo nel compito di fornire un'immagine del mondo; anzi si può dire che distaccandosi progressivamente $^{3}$ dalla filosofia, la scienza lotti per raggiungere l'egemonia nel definire i termini stessi secondo cui sarebbe possibile comprendere la realtà come autentica. Tale è, in sintesi, l'ossatura interna del naturalismo, dopo aver delineato la quale è possibile aprirsi al confronto con la filosofia di Spinoza.

Il filosofo olandese - come i critici non hanno mai mancato di sottolineare $-{ }^{4}$ s'inserisce pienamente tra quelli che accolgono positiva-

3 Un processo non lineare a cui hanno concorso diversi elementi: «Se nel Seicento comincia a delinearsi la scienza ma non ancora lo scienziato, l'età dei Lumi vede ormai come protagonisti l'una e l'altro. [...] Il Settecento rappresenta per l'uomo di scienza una sorta di età-laboratorio della modernità. In quell'epoca infatti giunsero a maturazione processi di lungo periodo come la fase di identificazione di un nuovo sapere, la sua legittimazione, il suo consolidamento istituzionale necessario per creare le basi di una vera e propria professione, così come apparvero all'orizzonte questioni nuove e laceranti tra cui spicca, per la prima volta ufficialmente dibattuto, il gran tema della demarcazione, cioè l'interrogativo su ciò che debba essere considerato scienza e ciò che invece è da considerarsi estraneo ad essa» (Ferrone 1994, 61-2).

4 Si veda a tal proposito Messeri 1990 e il volume monografico «Spinoza's Epistemology» (Curley, Mignini, Klever 1986). 
mente il nuovo modo di accostarsi al «Libro della Natura». ${ }^{5}$ Tuttavia la partecipazione di Spinoza non è ascrivibile solo ad un interesse erudito o alla passiva curiosità per il nuovo. Fin dai primi scritti, in effetti, emerge chiaramente quale sia la tensione che anima il filosofo nello studio delle scienze, il cui esito vorrebbe essere il «conseguimento della suprema perfezione umana» (TIE, § 16); si tratterebbe della capacità dell'uomo di pervenire ad una più stabile esistenza, entro un percorso che si prefigura come inscindibile da quello di tutti gli altri individui:

Questo è dunque il fine al quale tendo: acquisire tale natura e sforzarmi affinché molti l'acquisiscano con me. Ciò significa che è costitutivo della mia felicità anche adoperarmi a che molti altri intendano la stessa cosa che intendo io, affinché il loro intelletto e la loro cupidità convengano pienamente con il mio intelletto e la mia cupidità. (TIE, § 14)

«Perfezione umana» che rimane irraggiungibile se non si adopera una capacità intellettuale in grado di dare conto della «conoscenza dell'unione che la mente ha con l'intera natura» (TIE, § 13), ovvero, diventare consapevoli di far parte di quell'unico essere oltre il quale non vi è alcun essere e in virtù di quanto tutto avviene, «secondo un ordine eterno e secondo leggi determinate» (TIE, § 12).

Per Spinoza, quindi, lo studio della natura comprende sempre una dimensione etica irrinunciabile. Non si può progredire veramente nella conoscenza se non ci si prodiga affinché anche gli altri vi pervengano. Più sottilmente ciò implica che nella relazione che si instaura con l'altro si sia anche disposti, in qualche modo, ad aprirsi allo scambio. Un progetto ambizioso, a cui Spinoza dedicherà gli sforzi di una vita ${ }^{6}$ e che acquista forma sistematica nelle pagine dell'Etica e sicuramente non privo di ostacoli come si vedrà a breve.

Dopo questa breve contestualizzazione, è forse possibile comprendere meglio perché all'inizio della trattazione si è stati cauti riguardo la possibilità di utilizzare l'etichetta 'naturalismo' per Spinoza. Per quanto, infatti, a orientare la sua riflessione sia proprio il nuovo modo d'intendere e d'indagare il mondo, non vi è però una vera e propria separazione di ruoli tra filosofia e scienza; anzi alcune delle parole-chiave dello spirito scientifico (es. natura, metodo, estensione, moto), vengono utilizzate per dar conto della dimensione etica e politica propria dell'uomo.

5 Come testimonia ampiamente la corrispondenza di Spinoza. A tal proposito si veda la questione degli spettri affrontata nella lettera scritta a Hugo Boxel (Ep, LVI) e le riflessioni date a Henry Oldenbourg (Ep, XI) rispetto al trattato sul nitro di Boyle.

6 Oltre all'Etica, si pensi al ruolo centrale che questa dimensione 'comunicativa' riveste nel Trattato teologico-politico. 
L'approccio inaugurato dalla Rivoluzione scientifica non viene utilizzato per 'disporre' una gerarchia entro i saperi, quanto per 'dimostrare' che la natura racchiude in sé tutte le condizioni per il pieno e libero sviluppo dell'uomo. Da un lato, quindi, si mostrerà che il rapporto che si delinea tra la natura e chi la osserva non ha i caratteri di un'immediata intelligibilità; la natura non è «quella pittura muta in un quadro» ( $E$ II, prop. XLIX, schol.) che si presta, in maniera chiara e distinta, ad essere interpretata. Dall'altro, proprio questa mancanza di trasparenza permetterà di chiarire quale fisionomia e funzione la nozione di metodo assume nel discorso spinoziano.

\section{Meravigliarsi della natura: pregiudizi e uso politico dei metodi conoscitivi}

Spinoza è consapevole che il proprio progetto etico possa risultare di difficile comprensione. Un problema dovuto non tanto al carattere esoterico dell'approccio scelto, ${ }^{7}$ quanto piuttosto alla persistenza di alcuni pregiudizi qualora si intraprenda lo studio della natura:

Ma poiché rimangono ancora non pochi pregiudizi che anche, anzi massimamente, potevano e possono impedire che gli uomini siano in grado di comprendere la concatenazione delle cose nel modo in cui l'ho spiegata, ho ritenuto che valesse la pena di sottoporli qui all'esame della ragione. E poiché tutti i pregiudizi che qui intraprendo a denunciare dipendono soltanto da questo unico pregiudizio, che comunemente gli uomini suppongono che tutte le cose naturali, come essi stessi, agiscano in vista di un fine. (E I, app.; corsivi aggiunti)

Alla base dell'incapacità umana di cogliere la concatenatio delle cose naturali - ovvero l'infinita potenza di Dio - vi è un pregiudizio di base (praejiudicia pendant ab hoc uno), il finalismo. Quest'ultimo è, a sua volta, l'inevitabile conseguenza di un'errata convinzione umana riguardo la libertà delle proprie scelte. Una convinzione che scaturisce dall'uso della sola immaginazione, una facoltà che opera sempre con idee incomplete: ${ }^{8}$ inganna gli uomini illudendoli di essere liberi perché, se da una parte li rende consapevoli di desiderare alcune cose, dall'altra non permette loro di riflettere sulle «cause che li dispongono a ricercare e volere». È l'assenza di un ulteriore passaggio

7 La filosofia di Spinoza è un cammino che potenzialmente tutti possono intraprendere, si veda a tal proposito $E \mathrm{~V}$, pp. XLI-XLII e scolii.

8 Il tema dell'immaginazione è centrale nell'economia del pensiero spinoziano e non si limita ad una sua ricezione esclusivamente negativa, come segnalano tra gli altri Bertrand (1983), Bostrenghi (1996), Mignini (1981), Vinciguerra (2005). 
riflessivo a far identificare tout court l'umana libertà con la libera volontà di scelta9 $\mathrm{e}$ a indirizzare gli uomini sempre verso la conoscenza delle «cause finali di ciò che è avvenuto». Un modello conoscitivo utilizzato non solo per dar conto dell'agire umano ma che viene indiscriminatamente applicato anche alla natura e al suo studio:

Siccome poi scoprono in se stessi e fuori di sé non pochi mezzi che contribuiscono notevolmente al raggiungimento del loro utile, come per esempio gli occhi per vedere, i denti per masticare, i vegetali e gli animali per nutrirsi, il sole per illuminare, il mare per alimentare i pesci, va a finire che considerano tutte le cose naturali come mezzi per il loro utile, e poiché quei mezzi sanno di averli scoperti, ma senza averli predisposti, ne hanno tratto motivo per credere che ci sia qualcun altro che li avrebbe predisposti ad uso loro. (E, I, app.)

Spinoza non solo è convinto che il pregiudizio finalistico antropomorfizzi la natura ma, come sottolinea più avanti nel testo dell'Appendice, lo reputa lo strumento con cui si sono fornite «le nozioni in base alle quali spiegare la natura delle cose», nozioni quali bene e male, bello e brutto, ordine e confusione. I valori morali ed estetici che l'uomo ha così approntato e che crede assoluti non sono che illusori. La loro formulazione è, infatti, frutto di un meccanismo puramente soggettivo e singolare che assume oggettività a partire da una prospettiva erroneamente teleologica. È quanto suggeriscono le sfumature verbali e lessicali adoperate da Spinoza nel descrivere questo procedimento: l'uomo sembra trovarsi, suo malgrado, 'necessitato' a costruire tali valori basandosi, tra le tante possibili esperienze vissute, su quelle che ricorrono con maggiore evidenza «[homines] judicare debuerunt [...] illa omnia praestantissima aestimare, a quibus optime afficiebantur» (E, I, app.).

Dal percorso fin qui seguito è possibile trarre alcune considerazioni. Con l'utilizzo della sola facoltà immaginativa è impossibile pervenire a una comprensione autentica della natura. Bisogna essere in grado di guidare l'immaginazione lungo la via delle cause che esprimono realmente l'ordo et connexio naturae. Ė necessario, quindi, comprendere meglio l'impasse in cui si trova l'immaginazione qualora si rivolga allo studio della natura. Nell'approccio a questo compito, infatti, si possono assumere due atteggiamenti: o indagare i fenomeni naturali come un dotto (quique res naturae ut doctus intelligere) oppure ammirarli come uno stolto (ut stultus admirari). Se si fa brevemente mente locale sul ruolo che la meraviglia ha giocato nel discor-

9 «Ex his enim sequitur, primo, quod homines, se liberos esse, opinentur, quandoquidem suarum volitionum, suique appetitus sunt conscii» (E, I, app.). Sul tema cf. Ep, LVIII. 
so filosofico, non si può non rimanere sorpresi dalle parole di Spinoza. Infatti, se lungo l'arco della storia della filosofia la meraviglia è stata considerata come quel principio che promuoveva la ricerca filosofica e che poteva esserne motore - si considerino a tal proposito le riflessioni di Platone (Teet, 11, 155 d), Aristotele (Met, 1, 2, 982 b12 ss.) e Cartesio (Passions de l'âme, II, 53) $-^{10}$ le parole di Spinoza appaiono invece come una svalutazione della meraviglia. ${ }^{11}$

Questo cambio di prospettiva viene confermato dalla definizione di meraviglia contenuta alla fine della terza parte dell'Etica:

La meraviglia è l'immaginazione di una cosa sulla quale la mente si fissa per il fatto che questa singola immaginazione non ha alcun nesso con le altre. (E, III, def. aff. IV; corsivi aggiunti)

Nella spiegazione che segue la definizione vengono messi in luce alcuni aspetti interessanti. L'assenza di connessione dell'immaginazione in quanto admiratio non può imputarsi a una caratteristica della cosa ammirata; è per questo che Spinoza rimarca che, anche nel caso 'limite' del presentarsi di un'immagine di una cosa nuova, bisognerebbe sempre considerarla «della stessa natura delle altre». Questa sconnessione, o, più giustamente «distrazione della mente», non ha una causa oggettiva nella realtà di cui si fa esperienza: ha origine solo in noi. È per meglio comprendere questo aspetto che, all'inizio del testo della spiegazione della definizione, viene richiamato il testo della proposizione XVIII della seconda parte con il suo scolio, dove si illustra il funzionamento del processo immaginativo e mnemonico:

Se il corpo umano sarà stato una sola volta colpito da due o più corpi simultaneamente, quando poi la mente ne immaginerà uno, subito, si ricorderà degli altri. [...] E da qui inoltre intendiamo chiaramente come mai la mente, partendo dal pensiero di una cosa passi (incidat) al pensiero di un'altra che non ha alcuna somiglianza con la precedente: come per esempio, un antico romano dal pensiero della parola pomum passa subito al pensiero di un frutto che non ha alcuna somiglianza né alcunché in comune con quel suono articolato, se non il fatto che il corpo di quell'uomo è stato spesso colpito da quelle due cose, ossia, che quell'uomo ha spesso sentito la parola pomum mentre vedeva quel frutto. (E, II, prop. XVIII, sch.)

10 Il discorso sulla meraviglia in Cartesio assume delle sfumature che lo differenziano, in parte, dalla riflessione antica, si veda a tal proposito Scribano 2017.

11 Su questo tema più studiosi si sono confrontati, cercando di rintracciare le fonti da cui parte Spinoza per poi vederne il suo differenziarsi (cf. Scribano 2017; Severac 2005, 244-301; Piro 2009; Vinciguerra 2005, 43-56). 
Come ha giustamente sottolineato Pascal Sévérac $(2010,12)$ il processo immaginativo è regolato dal 'passare' (incidere) del pensiero di una cosa al pensiero di un'altra; è un meccanismo dinamico quello rappresentato dalla mente che immagina, poiché nell'atto immaginativo la mente cerca di seguire ${ }^{12} l^{\prime}$ 'ordine e la concatenazione delle immagini inscritte nel corpo. Un tentativo di comprendere, in termini più generali, il rapporto di unione che intercorre tra la Natura e la molteplicità delle sue parti. La meraviglia, al contrario, è indice di grande passività (Sévérac 2010,12) perché, come dichiara la definizione, non fa altro che fissare la mente su una singola immagine, facendola apparire straordinaria, in quanto percepita al di fuori del comune ordine naturale. Una deriva di cui Spinoza non manca di sottolineare la pericolosità, al fine di mettere in guardia i propri interlocutori da chi utilizza la meraviglia per soggiogare gli altri o avere un tornaconto politico:

Vi dirò schiettamente che cosa penso delle ragioni e delle storie dalle quali conchiudete che «esistono spettri di tutti i generi, salvo forse che di genere femminile». Il motivo per cui non vi ho risposto prima è che non ho a mano i libri da voi citati e non ho potuto trovare che Plinio e Svetonio. Ma questi due mi dispensano dalla fatica di cercare altri, perché sono persuaso che essi farneticano tutti allo stesso modo e sono ghiotti di storie straordinarie che lasciano attoniti e pieni di meraviglia (quae attonitus reddunt, ac in admirationem rapiunt). Io confesso che mi stupisco (fateor me obstupuisse), non tanto delle storie stesse, quanto piuttosto di coloro che le scrivono. Mi stupisco (miror) che uomini d'ingegno e di giudizio sprechino la loro eloquenza nel tentativo di farci credere simili fandonie. (Ep, LVI; corsivi aggiunti)

E come esplicitamente denuncia il testo dell'appendice che contiene le due possibili prospettive riguardo lo studio della natura:

12 Il corrispettivo etimo latino sequi, compare nell'Etica, per spiegare e caratterizzare il dispiegamento dall'unità al molteplice $(E, I$, prop. XV): «Questo verbo connota il rapporto secondo una forte accentuazione logico-geometrica. Non è casuale che nei trattati di geometria esso venga impiegato per indicare la derivazione delle proprietà dalla definizione. In questo contesto, l'utilizzo di tale verbo implica che le parti della natura instaurino con l'unità un rapporto di derivazione necessario. L'impiego del verbo sequi rende il rapporto fra Dio e natura scevro da ogni connotazione creativa» (Cerrato 2008, 247). L'immaginazione è sì un genere di conoscenza 'imperfetto' ma, essendo in grado di seguire l'ordine delle affezioni del corpo, contiene già in sé la potenzialità per un suo successivo correggersi. 
E così avviene che colui il quale ricerca le vere cause dei miracoli si sforza di intendere le cose naturali come dotto e non di ammirarle come uno stolto, per lo più è considerato e dichiarato come eretico ed empio da coloro che il volgo adora quali interpreti della natura e degli Dei. Sanno infatti che, eliminata l'ignoranza, viene tolto anche lo stupore, cioè l'unico mezzo che essi abbiano di argomentare e difendere la propria autorità. (E, I, app.; corsivo aggiunto)

Lo sguardo critico dell'autore non si limita quindi a rilevare la povertà epistemologica dell'admiratio quale approccio al mondo naturale, ma ne mette pure in luce un risvolto antropologico problematico. L'ammirazione costituisce infatti un arresto del processo cognitivo che contribuisce a innescare quei meccanismi politico-simbolici finalizzati ad «argomentare e difendere» l'ordine costituito. Ecco qui emergere quella tensione etico-politica cui si accennava in precedenza: per Spinoza l'epistemologia è sostanzialmente intrecciata alla politica, laddove una conoscenza fallace o carente può essere facilmente piegata ai fini di un controllo politico. Questa presa di coscienza critica non dovrebbe stupire se, in quest'ottica, ci si rivolge ad altri luoghi della produzione spinoziana come la Prefazione del Trattato teologico-politico. In tal senso riprendendo le indicazioni di Chantal Jaquet $(2013,52)$, il Trattato teologico-politico appare «uno strumento di analisi privilegiato», per la posizione mediana che occupa nello sviluppo del pensiero del filosofo olandese. Il testo della Prefazione presenta, infatti, alcune riflessioni che già si sono incontrate nell'esaminare il rapporto che intercorre tra superstizione e immaginazione; e, anzi, alcuni passaggi chiariscono come un certo modo di conoscere, l'admiratio, rivesta un ruolo strategico nel veicolare una specifica visione del mondo e dei rapporti tra gli individui:

Se poi assistono a qualcosa d'insolito, che susciti in loro grande meraviglia, credono si tratti di un prodigio; [...] e inventano così un'infinità di cose, interpretando la natura - quasi che questa sragionasse insieme a loro - nei modi più strani. (TTP, praef., § 2; corsivo aggiunto)

E poco più avanti:

Interrogandomi sulla causa di questo male [il travisamento del messaggio cristiano], non ho mai dubitato che la sua origine fosse da ricercarsi nel fatto che per il volgo la religione è sempre consistita nel ritenere i misteri ecclesiastici dei gradi di prestigio, $e$ i doveri della Chiesa dei privilegi, e nel tenere i pastori in sommo onore. Quando nella Chiesa cominciò ad affermarsi questo abuso [...], il fervore nel diffondere la religione divina degenerò in sordida avidità $e$ in ambizione, e così il tempio stesso in un teatro dove 
non si ascoltavano più dottori della Chiesa, ma oratori, nessuno dei quali desiderava istruire il popolo, ma solo conquistarne l'ammirazione, attaccare pubblicamente i propri avversari e insegnare solamente cose nuove e insolite di cui il volgo soprattutto restasse ammirato; ne dovettero certamente nascere grandi tensioni, invidie e un odio che nemmeno il volgere del tempo è riuscito a sedare. (TTP, praef., § 9; corsivi aggiunti)

È l'ammirazione in quanto fissazione ostinata dell'attenzione su un singolo oggetto (i misteri ecclesiastici, i doveri, i pastori), che, creando una sorta di legame feticistico con ciò che si osserva, permette quell'atteggiamento di rispetto, di reverenza ${ }^{13}$ verso determinate istituzioni e che da esse viene controllato. Un delinearsi dei rapporti sociali e politici compromesso in partenza e foriero di «tensioni, invidie e odi» difficili da sedare, perché basato su una conoscenza parziale della natura e del suo funzionamento. ${ }^{14}$ Se, dunque, provare ammirazione verso i fenomeni naturali conduce a sragionare e il perseverarvi «sovverte completamente la natura», qual è la strada per res naturales, ut doctus, intelligere?

\section{Alia veritatis norma: rivedere il metodo}

Si tratta ora di comprendere quale ruolo Spinoza assegni al concetto di metodo nel campo della conoscenza e quale ne sia il contenuto. Un approccio alla questione è dato da alcuni famosi giudizi che $\mathrm{He}$ gel, all'interno dei suoi corsi di filosofia alla Humboldt Universität, esprime su Spinoza:

Parrebbe dunque che il metodo dimostrativo matematico di Spinoza sia unicamente un difetto della forma esteriore: invece è l'errore fondamentale di tutta la sua concezione. Questo misconosce affatto la natura del sapere filosofico e l'oggetto di esso: infatti la conoscenza e il metodo della matematica sono meramente formali quindi affatto disadatti alla filosofia. La conoscenza matematica applica la dimostrazione all'oggetto esistente in quanto tale, non in quanto concepito; le manca affatto il concetto mentre il contenuto della filosofia è il concetto e il concepito. Questo concetto, in quanto conoscenza dell'essenza, è quindi semplicemente trovato

13 La reverentia viene presa in considerazione da Spinoza all'altezza del XVII capitolo del Trattato teologico-politico, come quella passione - misto di ammirazione e paura funzionale a garantire il perdurare dell'obbedienza. Sul rapporto tra fissazione ostinata o, meglio, allucinatoria e meccanismi di legittimazione del potere si veda Visentin 2012 14 L'ammirazione è una condizione instabile e soggetta a venire meno con l'abitudine e le delusioni, cf. TP, V, 4. 
e cade nel soggetto filosofico: e questo si mostra appunto nel metodo specifico della filosofia spinoziana. (Hegel, Lezioni sulla storia della filosofia, III/2, 137)

Spinoza, secondo Hegel, non farebbe altro che ripercorre la strada a suo tempo battuta da Cartesio: il processo di verificazione del contenuto della filosofia viene garantito dal seguire o meno l'ordine dimostrativo. L'oggetto della filosofia - «il concetto e il concepito» - passa in secondo piano a scapito della forma argomentativa che viene scelta. Sono le relazioni reciproche che organizzano le proposizioni e che si strutturano a partire da definizioni prime a essere regola del vero. Sparisce, agli occhi di Hegel, il concetto quale determinazione reale, ciò che è vero in sé e per sé. ${ }^{15}$

L'analisi hegeliana è certamente severa e a tratti - come già altri hanno suggerito (Macherey 1979, 59) - sembra rivolgersi più a Descartes, utilizzando Spinoza come pretesto. Tuttavia le sue considerazioni sintetizzano bene le osservazioni e le perplessità di quanti nel corso dei secoli si sono confrontati con il famigerato mos geometricus. ${ }^{16}$ Per quanto si sia abituati a considerare la nozione di metodo legata a doppio filo all'opera che, dopo la sua morte, ha consolidato la fama di Spinoza, è utile riprendere alcuni passi del Tractatus de intellectus emendatione sotto la scorta delle lucide analisi di Pierre Macherey $(1979,55-68)::^{17}$

15 «La filosofia spinoziana è già contenuta tutta intiera in queste definizioni, che però in complesso sono formali; questo cominciare sempre con definizioni è un difetto generale di Spinoza. In matematica è una cosa ammissibile, perché si prendono le mosse da presupposti, come il punto, la linea ecc.; ma in filosofia il contenuto si deve conoscere come quel ch'è vero in sé e per sé. Si può certamente concedere che sia esatta la definizione nominale, per modo che la parola 'sostanza' corrisponda alla rappresentazione che ci offre la definizione; altra cosa è però, se questo contenuto sia poi vero in sé e per sé. Simile quesito non sorge affatto per le proposizioni geometriche, ma per la considerazione filosofica è proprio quel che più conta; e Spinoza lo trascura. Invece di limitarsi a spiegare nelle definizioni, ch'egli formula, e a presentare come concreti questi pensieri semplici, sarebbe stato necessario indagare se questo contenuto sia anche verace» (Hegel, Lezioni sulla storia della filosofia, III/2, 116-17).

16 Sul metodo geometrico e la sua fortuna nel Seicento un riferimento imprescindibile è il saggio di De Angelis (1964). Per un'analisi, invece, che ne veda gli sviluppi il rimando è a Basso 2004.

17 L'analisi di Macherey continua e approfondisce le suggestioni proposte da Gueroult: «On peut comprendre maintenant le rapport que, à cet égard, soutiennent entre eux le De intellctus emendatione et l'Ethique. Alors que, procédant more geometrico, l'Ethique, située sur le plan de la théologie et de l'ontologie, fonde en droit, deductivement, par sa théorie de l'idée adéquate, la méthode génétique qu'elle pratique en fait, le De intellectus emendatione, situé sur le plan psycho-épistémologique, réfléchissant directement sur le fait de la connaissance géometrique, en dégage le concept de genèse interne comme celui de la seule méthode possibile pour la science adéquate des choses physiquement réelles. Saisissant dans la pensée geometrique l'acte fondamental de l'intellection et le processus nécessaire qui l'exprime, il y découvre l'essence même de l'entendement» $(1974,473)$. 
Avendo appreso quale conoscenza ci è necessaria si deve esporre il metodo con il quale conosciamo per mezzo di essa, quel che è da conoscere. Affinché ciò avvenga si deve innanzitutto considerare che qui non si darà una ricerca all'infinito, ossia: per trovare il metodo migliore per indagare la verità è necessario un secondo metodo che indaghi il metodo di indagine della verità e, per indagare il secondo metodo, è necessario un terzo e così via all'infinito. In tal modo non si perverrebbe mai alla conoscenza del vero, anzi a nessuna conoscenza. (TIE, § 30)

Il metodo non è l'espressione di una conoscenza in quanto tale, cioè oggettivabile. Per di più non esistono regole di produzione fissate al di fuori dell'esercizio effettivo del pensiero; ogni possibile norma estrinseca che ne vincoli il procedere a garanzia del conseguimento di uno statuto di verità perde la sua ragione d'essere.

Pertanto se vogliamo investigare la realtà che è prima di tutte, è necessario che si dia un qualche fondamento che diriga a quel punto i nostri pensieri. Quindi poiché il metodo è la stessa conoscenza riflessiva, questo fondamento, che deve dirigere i nostri pensieri, non può essere se non la conoscenza di ciò che costruisce la forma della verità e la conoscenza dell'intelletto, delle sue proprietà e delle sue forze. Acquisita infatti tale conoscenza, avremo un fondamento dal quale dedurre i nostri pensieri e la via attraverso la quale l'intelletto, per quanto consente la sua capacità, potrà giungere alla conoscenza delle cose eterne, tenuto conto certamente delle sue forze. (TIE, § 105; corsivi aggiunti)

Contrariamente a quanto avviene in Cartesio, per Spinoza, incanalare il pensiero lungo un metodo non vuol dire sondare i limiti del suo uso. Tutti possono in base alle proprie forze e alle proprie capacità giungere alla conoscenza delle cose eterne. Il metodo, poiché è diretto alla capacità che ciascuno possiede di conoscere degli oggetti e non agli oggetti stessi, presuppone in realtà l'esercizio di questa potenza (Macherey 1979, 56); logicamente poi ha per condizione preliminare le conoscenze che produce:

Da ciò si conclude che il metodo non è altro che conoscenza riflessiva o idea di idea. E poiché non si dà idea d'idea se prima non si dà idea. Perciò sarà buon metodo quello che mostra in che modo la mente debba essere diretta secondo la norma di un'idea vera data. (TIE, § 38)

Spinoza opera, quindi, una simultanea inversione e rivalutazione del metodo: da una parte, come appena mostrato, il metodo è un prodot- 
to, non viene prima ma dopo la conoscenza; ${ }^{18}$ dall'altra esso si prefigura, in parte, come censimento empirico di processi, esterno a ogni determinazione di quelle cause reali che ne dirigono il funzionamento. ${ }^{19}$ Come ha efficacemente sottolineato Macherey:

La méthode a perdu la fonction juridique de garantie que lui assignait la théorie cartésienne de la connaissance: elle n’a plus le pouvoir d'assigner à la vérité ses conditions originaires, mais elle en dégage après coup quelques propriétés, quelques aspects, de manière d'ailleurs isolée e arbitraire. (1979, 57; corsivo aggiunto)

La perdita della «funzione giuridica di garanzia» apre a una risignificazione completa del concetto di 'ordine': lo sviluppo di un ordine di conoscenza razionale non è più subordinato a una stretta gerarchia di operazioni successive il cui concatenamento sarebbe fissato una volta per tutte. Per Spinoza, l'ordine delle idee corrisponde a quello della loro produzione effettiva, la sua necessarietà non è legata, per l'appunto, da un obbligo legale, ma in ragione della causalità intrinseca dell'idea vera che determina a produrre la totalità degli effetti.

Qui si ha invece la stessa cosa che accade negli strumenti corporei, a proposito dei quali sarebbe possibile argomentare allo stesso modo. Infatti per battere il ferro è necessario il martello e per avere il martello è necessario produrlo; per questo c'è bisogno di un altro martello e di altri strumenti, per avere i quali ci sarà bisogno di altri strumenti e così all'infinito; ma in tal modo ci si sforzerebbe invano di provare che gli uomini non hanno alcun potere di battere il ferro. Invece, come gli uomini all'inizio poterono fare alcune cose molto facili con strumenti innati, anche se con fatica e imperfettamente e, costruite queste, ne costruirono altre più difficili e con minor fatica e maggior perfezione, così, avanzando gradualmente da opere semplicissime agli strumenti e dagli strumenti ad altre opere e altri strumenti, giunsero al punto di compiere tante opere e così difficili con poca fatica. Allo stesso modo anche l'intelletto, mediante la sua forza innata, si appronta degli strumenti intellettuali, con i quali acquisisce altre forze per altre

18 A supporto di tale affermazione Macherey ha portato l'esempio del 'metodo storico' utilizzato da Spinoza nell'interpretazione delle Scritture. Solo al capitolo VII dopo aver proceduto all'analisi delle profezie e miracoli, Spinoza spiega il suo metodo, mostrando che bisogna far funzionare un metodo prima addirittura di poterlo formulare (Macherey 1979, 57).

19 «Per comprendere queste altre idee, almeno secondo quanto esige il metodo, non è necessario conoscere la natura della mente attraverso la sua causa prima, ma è sufficiente approntare una breve descrizione della mente al modo che insegna Bacone» (Ep, XXXVII). 
opere intellettuali, e da queste opere altri strumenti, ossia la capacità di indagare ulteriormente avanzando in modo graduale fino ad attingere il culmine della sapienza. (TIE, §§ 30-31; corsivi aggiunti)

\section{Conclusione}

Il paragone proposto da Spinoza tra metodo, conoscenza e arti meccaniche è tratto dall'ottava delle Regulae ad directionem ingenii di Cartesio. La conclusione che ne viene tratta è, però, diametralmente opposta. Non è possibile operare una separazione netta tra metodo e conoscenza, tra gli strumenti che si adoperano e ciò che viene prodotto. Tutto, infatti, si produce per mezzo di una «forza nativa», cioè interiore, che si svolge secondo un naturale e necessario processo di graduale aggiustamento tra gli strumenti e le opere e viceversa. La pratica confuta qualsiasi norma dimostrativa che si situi al di fuori di questo processo: la conoscenza impiega degli strumenti nella misura in cui li ha elaborati. Il passaggio da un minore a un maggiore grado di sapienza è un'attività costante e interna sullo sfondo di leggi che operano allo stesso modo secondo vincoli necessari $(E$, II, prop. XXXVI).

È a questa altezza che è possibile comprendere in pieno alcune delle sollecitazioni proposte nell'introduzione del presente articolo. Proprio perché pensare adeguatamente significa svolgere un'azione contraria a ciò che, non solo rende schiavi nella mente, ma obbliga anche il corpo (cf. E, II, prop. XIV), la riflessione epistemologica spinoziana si estende alla questione della libertà. Poiché a una maggiore potenza della propria mente e quindi del proprio corpo corrisponde un impulso espansivo verso altri corpi e altre menti, si amplierà anche il raggio d'azione all'interno della Natura, ovvero di quel «solo individuo le cui parti, cioè tutti i corpi, variano in infiniti modi senza alcun mutamento dell'intero individuo» (E, II, lem. VII, schol.). Pertanto, la categoria di 'naturalismo' è applicabile a Spinoza solo a condizione di non sclerotizzare l'immane produttività della natura, sottoponendola ad un metodo d'indagine rigidamente normativo; al contrario, l'invito del filosofo è di utilizzare un metodo marcatamente euristico nella sua adattabilità. 


\section{Lista delle abbreviazioni}

\section{Opere di Spinoza}

$\begin{array}{ll}\text { E } & \text { Ethica } \\ \text { Ep } & \text { Epistolae } \\ \text { TIE } & \text { Tractatus de intellectus emendatione } \\ \text { TP } & \text { Tractatus Politicus } \\ \text { TTP } & \text { Tractatus theologico-politicus }\end{array}$

\section{Abbreviazioni per le citazioni dall'Etica, dal TTP e dal TP}

$\begin{array}{ll}\text { aff. def. } & \text { affectum definitio } \\ \text { app. } & \text { appendix } \\ \text { def. } & \text { definitio } \\ \text { lem. } & \text { lemma } \\ \text { praef. } & \text { praefatio } \\ \text { prop. } & \text { propositio } \\ \text { schol. } & \text { scholium }\end{array}$

\section{Bibliografia}

Basso, Paola (2004). Il secolo geometrico: La questione del metodo matematico in filosofia da Spinoza a Kant. Firenze: Le Lettere.

Bertrand, Michèle (1983). Spinoza et l'imaginaire. Paris: Presses universitaires de France.

Bostrenghi, Daniela (1996). Forme e virtù dell'immaginazione in Spinoza. Napoli: Bibliopolis.

Cerrato, Francesco (2008). Cause e nozioni comuni nella filosofia di Spinoza. Macerata: Quodlibet.

Curley, Edwin; Mignini, Filippo; Klever, Win (1986). «Spinoza’s Epistemology». Num. monogr., Studia Spinozana, 2.

De Angelis, Enrico (1964). Il metodo geometrico nella filosofia del Seicento. Firenze: Le Monnier.

De Caro Mario; Macarthur David (eds) (2004). Naturalism in Question. Cambridge (MA): Harvard University Press.

Ferrone, Vincenzo (1994). «L'Età dei Lumi». Rossi, Paolo; Ferrone, Vincenzo (a cura di), Lo scienziato nell'età moderna. Roma-Bari: Laterza, 61-129.

Gueroult, Martial (1974). Spinoza: II. L'âme (Ethique, II). Paris: Aubier.

Hegel, G.W. Friedrich (1964). Lezioni sulla storia della filosofia, vol. III/2. Firenze: La Nuova Italia.

Jaquet, Chantal (2014). L'unità del corpo e della mente. Affetti, azioni e passioni in Spinoza. Milano; Udine: Mimesis.

Koyré, Alexandre (1976). Studi galileiani. Torino: Einaudi. 
Laudisa, Federico (2014). Naturalismo. Filosofia, scienza, mitologia. Roma-Bari: Laterza.

Laudisa, Federico; Datteri Edoardo (2011). La natura e i suoi modelli. Introduzione alla filosofia della scienza. Bologna: Archetipo.

Macherey, Pierre (1979). Hegel ou Spinoza. Paris: Maspero.

Messeri, Marco (1990). L'epistemologia di Spinoza. Saggio sui corpi e sulle menti. Milano: Il saggiatore.

Mignini, Filippo (1981). Ars imaginandi. Apparenza e rappresentazione in Spinoza. Napoli: Edizioni Scientifiche Italiane.

Piro, Francesco (2009). «L'ammirazione in Cartesio e Spinoza. Classificazione degli affetti e costituzione dello spazio antropologico». Laboratorio dell'ISPF, 6(1/2), 1-19. URLhttp://www.ispf.cnr.it/file.php?file=/ispf_lab/ documenti/saggi_2009_pirofrancesco_01.pdf (2019-01-07).

Quine, Willard V.O. (1969). Ontological Relativity and Other Essays. New York: Columbia University Press. Trad. it.: La relatività ontologica e altri saggi. Trad. di Michele Leonelli. Roma: Armando, 1986.

Scribano, Maria Emanuela (2017). «ll controllo delle passioni. Ascesa e caduta della meraviglia da Descartes a Spinoza». INGENIUM, 11, 151-61. DOI https://doi.org/10.5209/INGE.58364.

Sellars, Wilfrid (2007). La filosofia e l'immagine scientifica del mondo. Roma: Armando.

Sévérac, Pascal (2005). Le devenir actifchez Spinoza. Paris: Honoré Champion.

Sévérac, Pascal (2010). «L'admiration de la nature chez Spinoza». Ramond, Charles (éd.), Spinoza. Nature, Naturalisme, Naturation. Pessac: Presses Universitaires de Bordeaux, 11-25.

Spinoza, Baruch [1670] (2007). Tractatus teologico-politicus - Trattato teologico-politico. A cura di Pina Totaro. Napoli: Bibliopolis.

Spinoza, Baruch [1677] (2010). Etica. A cura di Paolo Cristofolini. Pisa: ETS.

Spinoza, Baruch [1677] (2011). Trattato Politico. A cura di Paolo Cristofolini. Pisa: ETS.

Spinoza, Baruch (2009). Epistolario. Mignini, Filippo; Proietti, Omero (a cura di), Opere. Milano: Mondadori.

Vinciguerra, Lorenzo (2005). Spinoza et le signe. La genèse de l'imagination. Paris: Vrin.

Visentin, Stefano (2012). «Volonté d'être esclave et désir d'être libre: Ambivalence de la multitude chez Spinoza». Jaquet, Chantal; Moreau, Pierre-François (éds), Spinoza transalpin: Les interprétations actuelles en Italie. Paris: Éditions de la Sorbonne, 183-205. DOI https://doi.org/10.400\%/books.psorbonne.271. 


\title{
Naturalisme et scepticisme Le problème de l'identité personnelle chez David Hume
}

Iris Douzant

Université Paris 1 Panthéon-Sorbonne, France; Università Ca' Foscari Venezia, Italia

\begin{abstract}
Hume is qualified as a naturalist in two respects: on the one hand, because he sets himself to observe natural phenomena and more precisely those relating to human nature; on the other hand, because nature refers to a mental activity that eludes the grasp of the thought that tries to seize it. Hume's dealing with the issue of personal identity creates a tension between these two meanings of naturalism - the power of nature seems to escape the understanding of the philosopher who tries to give reasons for it and both sides of Humian naturalism dissociate themselves. If this tension is not positively resolved, in the opinion of Hume himself, it is reduced through the use of a radical scepticism.
\end{abstract}

Keywords Naturalism. Scepticism. Personal identity. Consciousness. Self. David Hume.

Sommaire 1 Introduction. - 2 L’application de méthode expérimentale au problème de l'identité personnelle. - 2.1 Principes. - 2.2 L'identité personnelle comme fiction. - 3 Le conflit entre les deux acceptions du naturalisme humien. - 3.1 Les problèmes inhérents au versant constructif de la doctrine (théorie). - 3 La difficile concordance entre le tome I et le tome II du Traité. - 4 Conclusion.

\section{Introduction}

Hume entend, dans le Traité de la nature humaine, rendre intelligibles les principes qui régissent un certain type de nature : la nature humaine. Pour ce faire, il applique aux objets de la philosophie morale (ici la morale s'étend au psychique) une méthode qui a déjà fait ses preuves dans la philosophie 
naturelle parce qu'elle rendait intelligibles les principes de la nature : la méthode expérimentale mise au point par Newton. D’où le fait que Hume précise dans le sous-titre du Traité, que celui-ci constitue une «tentative pour introduire la méthode expérimentale de raisonnement dans les sujets moraux ». Hume oppose ainsi la science qui résulte de l'observation des comportements humains, la science de la nature humaine, à un certain type de raisonnement - qui repose sur des principes métaphysiques, et qu'il désigne comme le produit de la " philosophie abstruse ». On ne peut pas connaître ce qui est au-delà de l'expérience : la nature humaine ne se laisse comprendre qu'à partir de ses manifestations mentales. Le naturalisme de Hume, dans un premier sens, renvoie au fait qu'il traite des phénomènes de la nature humaine. ${ }^{1}$ La réunion des observations et leur comparaison permet de dégager une uniformité dans les comportements humains, qui est rendue lisible grâce à la récurrence de certaines conduites. Cette uniformité ou ces conduites uniformes constituent les principes de la nature humaine. Hume rejette alors autant ce qu'il nomme la «philosophie dogmatique » (qui peut être aussi bien rationaliste qu'empiriste) que le scepticisme radical. Le dogmatisme présume, à tort, accéder à la connaissance indubitable d'un au-delà de l'expérience; le scepticisme radical consiste dans la suspension généralisée de l'assentiment et conduit à l'aporie. ${ }^{2}$

Le naturalisme de Hume peut se comprendre, en un second sens, comme l'accent porté sur le déploiement effectif d'une nature humaine dont les pouvoirs se concrétisent dans la mise en œuvre de notre instinct - c'est-à-dire dans l'absence de réflexion - aussi bien que dans nos habitudes psychologiques (Hume 1995, I, III, XVI, 257). Ainsi, le naturalisme humien est-il tributaire d'un scepticisme modéré inhérent à la méthode expérimentale : des pouvoirs de la nature humaine, nous ne connaissons - nous ne pouvons analyser - que les effets, car ce sont eux seuls que nous pouvons observer. Autrement dit, alors que nous ne pouvons pas connaître les causes premières qui régissent les phénomènes humains, néanmoins l'observation et la comparaison des phénomènes nous permettent d'abstraire les lois qui régissent leur foisonnement apparent. « La critique et la doctrine se recouvrent l'une l'autre et se construisent conjointement. Tel est le sens du scepticisme modéré » (Brahami 2003, 24). Pourtant, selon nous, dans le traitement que Hume fait du problème de l'identité personnelle, alors que la critique est pleinement assumée, la doctrine ne semble pas concorder parfaitement avec elle. En effet, Hume, en

1 Sur le naturalisme de Hume, voir Kemp Smith 1966; Garrett 2006. Sur les rapports entre le naturalisme et le scepticisme dans l'œuvre de Hume, voir Stroud 2016.

2 Sur les rapports entre les différences espèces de scepticisme chez Hume, et notamment sur son usage d'un scepticisme mitigé plutôt que modéré, voir Jaffro 2011. 
vertu des principes de la science de la nature humaine, montre les contradictions inhérentes à la conception du moi comme entité ou substance qui aurait une existence à l'écart des perceptions qui en seraient le produit, conception relayée aussi bien par le sens commun que par les philosophes rationalistes et empiristes qui le précèdent (Hume 1995, I, IV, VI, 342-55). Lorsqu'il s'agit d'expliquer positivement la formation de l'idée fictive du moi du point de vue de la pensée, Hume considère d'abord que le processus est analogue à celui qui nous fait conclure à l'identité des objets. Néanmoins, dans l'Appendice au tome I du Traité, il met en doute cette explication, sans être en mesure, de son propre aveu, d'en proposer une autre. Le tome II propose quant à lui, et indépendamment du tome I, une explication de l'usage du moi pour les passions, mais cette explication qui entend compléter celle du tome I ne s'y substitue en rien. À partir de ce constat, nous pouvons envisager deux hypothèses : soit Hume outrepasse les limites de ce que la méthode expérimentale permet de connaître, soit il échoue à expliquer convenablement l'identité personnelle du point de vue de la pensée. ${ }^{3}$ Selon nous, c'est cette deuxième hypothèse qu'il faudrait retenir, car les principes de l'association des idées mobilisés par Hume dans le tome I du Traité ne lui permettent pas, au moment de la rédaction de l'Appendice - qui intervient après l'écriture du tome II du Traité - de rendre compte de l'existence de cette fiction. ${ }^{4}$ Il nous semble que dans l'explication de la formation de l'idée du moi, le naturalisme pris comme appréhension des phénomènes de la nature ne serait plus charpenté par un scepticisme modéré, mais le scepticisme radical viendrait s'immiscer dans le versant constructif de la doctrine humienne à cause du naturalisme entendu cette fois comme échappement des pouvoirs de la nature pour la pensée qui tente de les comprendre. Les deux sens humiens du naturalisme entreraient donc en un conflit, qui se résoudrait par la mise en œuvre d'un scepticisme radical.

3 Le problème humien de l'identité personnelle a été amplement traité par les commentateurs. Voir par exemple, Malherbe (2016), Salaün (2003), Penelhum (1992), Brahami (2003), Kemp Smith (1966).

4 Les deux premiers tomes du Traité de la nature humaine ont été publié en 1739. L'Appendice est publié en 1740. 


\section{L'application de méthode expérimentale au problème de l'identité personnelle}

\subsection{Principes}

Les principes humiens découverts par l'application de la méthode expérimentale newtonienne aux sujets moraux rendent compte de l'uniformité des processus de pensée qui animent l'esprit humain. Ces principes sont des « lois dérivées des phénomènes, que l'on s'efforce de rendre aussi générales que possibles, et qui nous sont connues par leurs effets » (Malherbe 2016, 62). Ils livrent une constance analogue à celle des lois de la nature. L'homme n'est pas « un empire dans un empire ", non pas parce qu'il serait soumis aux lois qui déterminent la nature, mais parce que les comportements humains pour Hume expriment des régularités qui ont la constance des lois (et que les exceptions confirment). ${ }^{5}$ Dans la mesure où ces principes sont des effets, il faut paradoxalement partir de l'observation des conduites de l'homme en société pour pouvoir rendre intelligibles les principes qui régissent sa nature. La nature pour Hume n'est un fait primitif qui serait modifié par la société : c'est dans le «cours ordinaire du monde » (Hume 1995, Introduction, 37) et donc de la vie sociale qu'elle se déploie. ${ }^{6}$ Par conséquent, faire un retour sur soi purement réflexif pour analyser ses propres opérations mentales est incompatible avec la méthode expérimentale : la préméditation engendrerait une artificialité qui paradoxalement ne se retrouve pas dans le cours ordinaire du monde où la nature s'exerce. En ce sens :

l'entreprise humienne se caractérise [...] par la résorption du gouffre creusé par la philosophie traditionnelle, et notamment une certaine philosophie moderne (post-cartésienne) entre ce qui serait supposé être de l'ordre de la pensée et ce qui est de l'ordre de l'existence empirique de l'homme dans le monde, en tant que celle-ci relève en propre d'une nature. (Benoist 2003, 129)

En effet, c'est à partir de l'existence empirique de l'homme dans le monde, par la réunion et la comparaison des observations de cette existence, que l'on peut comprendre les phénomènes de la pensée. L'originalité de Hume peut être mieux saisie par différence avec Descartes. Il est probablement visé quand Hume rejette l'approche

5 Hume va jusqu'à reprendre à Newton le concept d'attraction pour désigner les trois principes d'association des idées (ressemblance, contiguïté, cause à effet). Voir Hume 1995 I, I, IV, 56.

6 Contrairement à Rousseau, pour lequel la nature humaine peut être déformée par la société. Voir L'Émile et le Second Discours. 
réflexive. Il n'est, selon Hume, nullement nécessaire de se retrancher du monde, comme le fait par excellence Descartes dans la Première des Méditations Métaphysiques, puisque l'expérience ne nous donne à voir que des effets - mieux, ces effets constituent l'expérience même. L'homme n'est pas un sujet qui se tient devant le monde et qui tente par la pensée d'en pénétrer les secrets : il n'importe pas de réfléchir sur l'adéquation de nos perceptions et du réel, mais de comprendre comment l'esprit est lui-même constitué, passivement, par les perceptions, par l'expérience. Hume affirme en ce sens : " Chez un animal à ce point sagace, ce qui naît inévitablement de l'exercice des facultés intellectuelles peut à juste titre être estimé naturel » (Hume 2002, Appendice III, 159). L'expérience ne peut désigner que l'expérience de l'homme (déployée dans le monde), c'està-dire ses contenus de pensée, et non pas une expérience réflexive de l'âme (repliée sur elle-même) qui prétendrait ainsi parvenir à se connaître comme principe actif de la connaissance, comme cause de ses idées - l'essence de l'esprit humain échappe à la connaissance. Rappelons que pour Descartes, dans la "Deuxième Méditation », je suis indubitablement certain que je suis une res cogitans, mais la véracité des contenus de mes pensées, leur adéquation avec la réalité, ne peut être garantie que par Dieu. Pour Hume, dans la mesure où est réel ce qui apparaitt (l'impression), le problème de la représentation est éliminé. Les facultés ne sont connues qu'en exercice, et les contenus de pensée de l'esprit sont la matière à partir de laquelle on peut inférer les principes formels qui l'animent (Hume 1995, Introduction, 37). Alors que Descartes distingue l'entendement de l'imagination et des sens, pour Hume l'entendement est synonyme d'imagination. Les trois principes d'association des idées (ressemblance, contiguïté, cause à effet) sont le fruit de l'imagination et constituent l'entendement : toutes nos pensées sont régies par ces connexions. On pourrait dire que Hume, qui n'entend rendre compte que de l'expérience empirique de l'homme, infléchit la distinction cartésienne entre les trois notions primitives, en considérant qu'il y a entre les passions et la raison une distinction de degré et non plus de nature, qui les rend perméables l'une à l'autre. ${ }^{7}$ Autrement dit, pour employer encore des termes cartésiens, la troisième notion primitive est au principe des deux autres pour Hume et ce qui chez Descartes relevait de l'union de l'âme et du corps, et ainsi échappait

7 «[L]'âme ne se conçoit que par l'entendement pur ; le corps, c'est-à-dire l'extension, les figures et les mouvements, se peuvent aussi connaître par l'entendement seul, mais beaucoup mieux par l'entendement aidé de l'imagination; et enfin, les choses qui appartiennent à l'union de l'âme et du corps, ne se connaissent qu'obscurément par l'entendement seul ni même par l'entendement aidé de l'imagination; mais elles se connaissent très clairement par les sens » (Descartes 1989, 73). Sur ce point, voir Salaün 2003, 98. 
à la connaissance théorique, retrouve sa place dans la philosophie, et même devient le principe qui rend intelligible les mécanismes de l'entendement. Nous ne pouvons pas connaître les causes des phénomènes mentaux, et l'entendement ne peut pas se connaître de manière réflexive. Ce qu'affirme Descartes de la substance pensante n'est, selon Hume, qu'une hypothèse. Hume, qui théorise les principes newtoniens en les étendant à la science de la nature humaine, affirme qu'il faut renoncer à faire des hypothèses sur l'essence de l'esprit humain : les hypothèses ne sont pas fondées sur ce qui est observable (Hume 1995, Introduction, 35). L'expérience et les hypothèses s'excluent mutuellement. L'hypothèse, bien qu'elle puisse être utile lorsqu'on la considère comme une supposition vérifiable par l'expérience, est vaine en tant qu'elle est un raisonnement établi « sur une supposition » (Hume 1995, I, III, IV, 145) qui ne renvoie pas à l'expérience : elle est alors fondamentalement fictive et n'a aucune utilité. La fiction, pour Hume, est justement ce qu'il faut dénoncer. Son scepticisme modéré se déploie contre les fictions de l'imagination que l'on finit par croire réelles si on ne les soumet pas au crible du premier principe de la nature humaine : «Toute idée réelle doit provenir d'une impression particulière » (Hume 1995, I, IV, VI, 343). L'idée du moi a ceci de particulier qu'elle est d'abord une fiction qui émane de la nature humaine que la philosophie moderne a ensuite transformé en hypothèse.

\subsection{L'identité personnelle comme fiction}

Hume, dans le chapitre 6 de la quatrième partie du tome I du Traité commence par critiquer différentes conceptions philosophiques de l'identité personnelle - Hume vise ici aussi bien Descartes que Locke, Berkeley et Malebranche - qui, si elles divergent entre elles dans leur détail, ont ceci de commun qu'elles considèrent le moi comme une entité distincte et indépendante des contenus de pensée qui le rempliraient (Hume 1995, I, IV, VI, 343): pour ces philosophes, il est indubitable que nous avons conscience de nous-mêmes. ${ }^{8}$ Dans le chapitre précédent, il critiquait l'idée de substance : la conscience renvoie à la substance pensante chez Descartes - Descartes, en apparence (car il y a Dieu), considère même que le « je pense », connu de façon immédiate par l'intuition est le premier des principes de la connaissance, que la connaissance de soi fonde la connaissance du monde. L'identité personnelle est constituée par la mémoire pour Locke, si elle ne renvoie pas à un substrat, elle constitue néanmoins

8 Pour l'analyse complète du chapitre du Traité de la nature humaine portant sur l'identité personnelle voir Salaün 2003, 60-93. 
une entité. ${ }^{9}$ Or, suivant le premier principe de la science de la nature humaine, toutes nos idées sont les copies de nos impressions, dérivent des impressions (Hume 1995, I, I, I, 47). Ce principe a la valeur d'une prescription méthodologique lorsqu'il s'agit de déterminer si une idée est vraie ou fictive : il est nécessaire de rechercher de quelle impression dérive l'idée que l'on cherche à analyser. Selon Hume, l'impression et l'idée sont de même nature et se distinguent par une différence de degré (Hume 1995, I, I, I, 41). Dans la mesure où l'impression est évanescente, et où les impressions se succèdent en formant un flux constant, c'est à l'instant où l'impression disparaît qu'elle devient une idée, d'où le fait que l'impression est antérieure à l'idée. L'idée a moins de force et de vivacité que l'impression, parce qu'elle en dérive, c'est parce qu'elle n'est qu'une impression conservée. La fulgurance de l'impression humienne constitue donc une expérience originaire - il n'y a d'impression et donc d'expérience à proprement parler que la première fois qu'un sentiment est éprouvé. Rien dans l'expérience, selon Hume, ne permet donc d'affirmer que ces impressions seraient rattachées d'une façon ou d'une autre à un pôle qui les soutiendrait. L'idée que nous avons du moi comme entité distincte du flux de nos impressions ne peut être que fictive car, lorsqu'on essaie d'en faire la genèse, on s'aperçoit qu'aucune impression ne correspond à cette idée.

Ainsi, nous feignons l'existence continue des perceptions de nos sens pour en supprimer la discontinuité, et nous aboutissons aux notions d'âme, de moi ; et de substance pour en déguiser la variation. (Hume 1995, I, IV, VI, 346)

En vertu du premier principe de la science de la nature humaine, l'esprit ne peut se comprendre que comme une succession d'impressions, ou mieux, il se réduit à une succession d'impressions :

Ce ne sont que les perceptions successives qui constituent l'esprit, et nous n'avons pas la plus lointaine idée du lieu où ces scènes sont représentées, ni des matériaux dont il est composé. (Hume 1995, I, IV, VI, 344)

En somme, « il ne faut pas dire que l'esprit a des impressions mais qu'il est ses impressions » (Salaün 2003, 48). La critique humienne de l'identité personnelle concerne donc le versant théorique de l'idée du moi : cela n'empêche donc pas Hume d'expliquer, dans le tome II du Traité, l'usage fait de l'identité personnelle du point de vue des passions. 


\section{Le conflit entre les deux acceptions du naturalisme humien}

\subsection{Les problèmes inhérents au versant constructif de la doctrine (théorie)}

Le scepticisme modéré de Hume implique qu'une critique ne peut pas être établie sans une explication du fonctionnement même du préjugé qui pose problème : Hume, après avoir critiqué l'idée du moi dont les philosophes font usage, explique alors le mécanisme mental de l'élaboration de l'idée du moi par analogie avec celui qui conduit à la croyance en l'identité des objets, végétaux ou animaux (Hume 1995, I, IV, VI, 351). ${ }^{10}$ Avant cela, il fait

une distinction entre l'identité personnelle, en tant qu'elle se rapporte à la pensée et à l'imagination, et en tant qu'elle s'attache à nos passions ou l'intérêt que nous prenons à nous-même. (Hume 1995, I, IV, VI, 344)

Cette distinction est primordiale car elle limite au domaine de la pensée l'explication à venir de la fiction du moi. Dans la croyance en l'identité des objets sont à l'œuvre les connexions de l'imagination, qui se ramènent à trois relations : la relation de ressemblance, de contiguité ou de cause à effet (Hume 1995, I, IV, VI, 347-51). Hume met sur le même plan, monnayant quelques distinctions, le processus de formation de l'identité des objets et de l'identité des personnes. Ainsi, l'idée du moi s'explique t-elle seulement par deux des relations de l'imagination, la ressemblance et la causalité, qui renvoient à la mémoire. D'une part, les idées conservées par la mémoire, les perceptions passées peuvent ressembler à de nouvelles perceptions, ce qui contribue à créer l'identité : l'imagination parcoure aisément, par une transition facile, ces différents chaînons, et

confondrait l'état dans lequel elle se trouve en parcourant cette suite avec l'état dans lequel elle se trouve lorsqu'elle perçoit un objet identique. (Glauser 1996, 19)

D'autre part, les relations causales animent en permanence l'esprit et chassent certains contenus de pensée au profit d'autres - la forme se maintient mais le matériau change - d'où la fameuse comparaison humienne entre l'âme et une république (Hume 1995, I, IV, VI, 353). ${ }^{11}$ Malgré les changements d'idées, les diverses parties sont toujours

11 Pour l'analyse de cette comparaison, voir Alanen 2014. 
reliées par la relation de causalité permise par la mémoire. Cette relation de causalité, selon Hume, révèle l'identité personnelle, par la transition facile qu'elle permet à l'imagination.

Néanmoins, dans l'Appendice au Traité de la nature humaine, Hume revient sur cette explication et dissocie l'explication de l'identité des objets et celle de l'identité des personnes. L'analogie ne peut pas, contrairement à ce qu'il présumait initialement, supporter le passage de l'externe à l'interne : si la méthode expérimentale permet de rendre compte de l'identité des objets, Hume s'est rendu compte après coup, qu'elle pose problème pour rendre compte du processus de formation de l'identité des personnes. La difficulté reconnue par Hume à ce propos, dans l'Appendice, semble liée au fait que les connexions de l'imagination (causalité, ressemblance) ne peuvent finalement pas expliquer la formation de l'identité personnelle, pour des raisons méthodologiques. Ce que Hume remet en cause, dans l'Appendice, c'est l'explication de la formation de l'idée du moi du point de vue de la pensée - le premier des deux versants de cette explication du «moi ». Cette explication pourtant, résultait de la mise en œuvre du scepticisme modéré, par distinction avec un scepticisme radical : cette distinction est capitale.

Être sceptique n'est pas prétendre qu'on doit suspendre son assentiment sur tout sujet, mais c'est montrer et savoir que lorsqu'on donne son assentiment, on le fait en vertu d'une causalité sur laquelle on n'a pas de contrôle et qui est très différente de raisons justificatives. (Jaffro 2011, 56)

Or, Hume se voit incapable ici de rendre compte de cette causalité, car son explication est en contradiction avec certains des principes de la science de la nature humaine. Il maintient donc le versant critique de l'idée de l'identité personnelle, car «nous n'en avons [de l'esprit] aucune notion qui soit distincte des qualités particulières » (Hume 1995, Appendice, 384), néanmoins il écrit :

Mais tous mes efforts s'évanouissent quand j'en viens à expliquer les principes qui unissent nos perceptions successives dans notre pensée ou notre conscience. Je ne peux découvrir de théorie qui me donne satisfaction sur ce point. (Hume 1995, Appendice, 385)

Hume, par ces propos, semble glisser vers le scepticisme radical en ce qui concerne l'identité personnelle. Ce glissement est motivé par une inadéquation entre des principes essentiels de la doctrine humienne, qu'il rappelle - « Toutes nos perceptions distinctes sont des existences distinctes et l'esprit ne perçoit jamais de connexion réelle entre ces existences distinctes » (Hume 1995, Appendice, 385) - et son explication de l'idée du moi. Cette inadéquation ne se révèle pas pour l'explication 
de l'identité des objets : l'esprit éprouve les connexions entre ses différentes perceptions particulières, et cela le conduit à former l'idée d'une identité de certains objets - ici les perceptions distinctes sont des existences distinctes, et l'esprit ne perçoit pas de connexion réelle entre ces existences distinctes. Mais comme l'affirme M. Malherbe,

alors que la liaison des impressions est de similitude, de contiguité et de causalité, dans le cas de l'objet dont l'identité est toujours remplie, il n'en va pas de même du moi, dont l'identité doit être posée dans la différence des perceptions, et dont la fiction est nécessairement celle d'une unité vide, étrangère à son remplissement, qui se fait par simple succession. (Malherbe 2016, 220-1)

En ce qui concerne l'identité personnelle, donc, Hume a expliqué dans le tome I du Traité que l'esprit qui éprouve différentes connexions se réfléchit lui-même comme étant ce en quoi consiste l'unité de ces connexions. Or, cela présuppose que l'esprit puisse percevoir des connexions réelles entre les perceptions. En vertu de la concomitance des deux principes rappelés par Hume, il est impossible d'affirmer que l'esprit pourrait se saisir lui-même réflexivement comme étant l'unité de ces connexions car cela supposerait que le moi en soit le principe - ici, la cause, la connexion réelle -, or des perceptions nous ne pouvons connaître que leur distinction et les connexions imaginatives qui les relient parce que nous les éprouvons.

Mais ayant délié toutes nos perceptions particulières, lorsque j'en viens à expliquer le principe de connexion qui les relie et nous fait leur attribuer une simplicité et une identité réelles, j'ai conscience que mon explication est très défectueuse et que seule l'apparente évidence des raisonnements précédents a pu m'induire à l'accepter. Si les perceptions ont des existences distinctes, elles ne forment un tout que par leur connexion réciproque. Mais aucune connexion entre les existences distinctes ne peut jamais être découverte par l'esprit humain. Nous ne faisons qu'éprouver une connexion ou une détermination de la pensée à passer d'un objet à un autre. (Hume 1995, Appendice, 385)

Il faudrait donc, pour expliquer l'identité personnelle, que l'esprit perçoive nécessairement les connexions réelles et non pas seulement les pensées entre ces existences distinctes, dans la mesure où il constituerait la synthèse de ces connexions elles-mêmes. Le moi ou l'esprit n'est pas un donné empirique mais il n'est pas non plus une relation, il est la synthèse de ces relations. Or, l'esprit ne peut pas se réfléchir en tant que qu'il est une synthèse. Cette fois, ce n'est pas tant que le retour réflexif sur soi est déshabilité en ce qu'il modifierait l'objet sur lequel il porte - ici l'esprit humain, mais 
c'est qu'en vertu des principes de la science de la nature humaine, l'esprit ne peut fondamentalement pas se réfléchir lui-même car sinon cela impliquerait que l'entendement ou l'imagination soit une unité et,å pour mieux dire, une conscience. Cela est impossible pour Hume et l'entendement, ou l'imagination, qui rassemble et lie, est donc impuissant à se fonder lui-même. Il échoue, pour expliquer la formation de l'idée du moi, à concilier les différents principes qu'il a dégagés : tout ce que nous pouvons connaître, c'est que l'esprit éprouve des connexions. Hume ne peut donc pas expliquer l'identité personnelle comme il explique l'identité des objets pour des raisons structurelles tenant à l'objet même qui est examiné : l'esprit luimême. La nature de l'esprit échappe à une saisie intellectuelle. Dans la mesure où la science de la nature humaine ne prétend expliquer que les effets, l'extériorité, Hume bute sur l'explication de l'intériorité. Ce qui fait problème précisément c'est la manière dont Hume a appliqué les principes de la méthode expérimentale à l'identité personnelle. " D'autres peut-être, ou moi-même après plus mûre réflexion, pourrons découvrir quelque hypothèse qui concilie ces contradictions » (Hume 1995, Appendice, 385-6). Dans la mesure où Hume reconnaît qu'il n'a pas de solution à apporter, le seul moyen qui lui reste pour conclure cette question c'est d'invoquer un scepticisme qui n'est pas modéré. "Pour ma part, il faut que j'invoque le privilège du sceptique et que j'avoue que cette difficulté est trop rude pour mon entendement » (Hume 1995, Appendice, 385). Par ailleurs, il ne reprendra pas le versant imaginatif du problème de l'identité personnelle dans l'Enquête sur l'entendement humain, et bien plus, il n'en dit pas un mot : ce silence remarquable permet d'appuyer l'idée d'un embarras de Hume à propos de l'analyse qu'il présente dans le tome I du Traité. Hume dévoile donc une limite de son application de la méthode expérimentale à la philosophie morale : l'incapacité à expliquer positivement la formation de l'idée du moi dans la pensée, et cette limite engendre l'inéluctabilité d'un scepticisme radical sur ce versant de la question.

\subsection{La difficile concordance entre le tome I et le tome II du Traité}

Il faut repartir de la distinction préliminaire qu'effectue Hume, dans le chapitre du Traité qui porte l'identité personnelle, entre l'usage théorique de l'idée du moi et son usage pratique : il déclare en effet qu'il

nous faut faire une distinction entre l'identité personnelle, en tant qu'elle se rapporte à la pensée et à l'imagination, et en tant qu'elle s'attache à nos passions ou à l'intérêt que nous prenons à nousmêmes. (Hume 1995, I, IV, VI, 345). 
Il nous faut lire cette déclaration en regard d'une autre qui trouve sa place dans le tome II du Traité :

Il est évident que l'idée ou plutôt l'impression de nous-mêmes nous est toujours intimement présente ; et notre conscience nous donne une conception si vive de notre personne qu'il n'est pas possible d'imaginer qu'aucune chose puisse la dépasser sur ce point. (Hume 2015, II, I, XI, 147)

Ces affirmations, selon Hume, constituent un corollaire à celles du chapitre 6 de la quatrième partie du tome I du Traité : il s'agit pour lui d'expliquer la formation de l'idée du moi en la considérant comme un fait analysable d'un point de vue cette fois affectif, celui des impressions de réflexion que sont les passions. Il s'agit en somme de rendre compte de la production affective de "l'intérêt que nous prenons à nous-mêmes », du souci de soi. Les impressions de réflexion (les passions) ne sont pas de l'ordre de la conscience réfléchie et sont, selon Hume, aussi originaires que le plaisir ou la douleur (impressions de sensation). Ainsi, si " l'idée ou l'impression de nous-mêmes nous est toujours intimement présente », c'est que les passions donnent au moi la puissance d'une impression : l'orgueil et l'humilité produisent le moi. On peut alors reprendre ici la formule de Malherbe : "L'idée du moi ne préexiste pas à la passion, mais en est le terme : c'est la passion qui l'invente » $(2016,238)$. L'idée du moi qui est ainsi produite est, selon Hume, l'objet de ces passions (Hume 2015, II, I, II, 101). Cette attribution de l'objet qu'est le moi aux passions est le fruit de la nature. Ainsi, du point de vue de l'explication du moi relativement à l'intérêt que nous portons à nous-même, Hume ne rencontre-t-il pas de difficultés dans l'application de la méthode expérimentale.

Y a-t-il dès lors une complémentarité entre le tome I et le tome II du Traité sur la question de l'identité personnelle ? Il y en a une pour Hume, car du point de vue de la science de la nature humaine, le versant pratique de l'explication vient compléter son versant théorique, les deux réunis rendant compte de l'ordre de l'existence empirique de l'homme dans le monde. Mais il nous semble que cette réunion est moins le fruit de l'application de la méthode expérimentale aux sujets moraux et du scepticisme modéré qu'induit cette application, que celui d'une attitude sceptique radicale, et cela même si l'on ne tient pas compte des déclarations de l'Appendice - car souvenons-nous que Hume a écrit le tome II avant l'Appendice. Il nous faut rappeler que Hume, dans le dernier chapitre du Traité, se trouve en proie à une crise sceptique, aux accents cartésiens, suscitée par son humeur morose.

La considération intense de ces multiples contradictions et imperfections de la raison humaine a tant agi sur moi et tant 
échauffe mon cerveau que je suis prêt à rejeter toute croyance et tout raisonnement, et que je ne peux même plus regarder une opinion comme plus probable ou plus vraisemblable qu'une autre. Où suis-je ? Que suis-je ? [...] Fort heureusement, il se trouve que, puisque la raison est incapable de disperser ces nuages, la nature elle-même y suffit et me guérit de cette mélancolie et de ce délire philosophiques, soit par le relâchement de cette disposition de l'esprit soit par quelque distraction et quelque impression vive de mes sens, qui efface toutes ces chimères. Je dîne, je fais une partie de jacquet, je converse et me réjouis avec mes amis et quand, après trois ou quatre heures d'amusement je veux reprendre ces spéculations, elles m’apparaissent si froides, si forcées, si ridicules que je ne peux pas trouver le cœur de les poursuivre plus avant. (Hume 1995, I, IV, VII, 362)

Comment sortir du scepticisme radical ? Comme il l'affirme, dans la section XII de l'Enquête surl'entendement humain (Hume 2006, XII, 241), à propos du pyrrhonisme érigé comme doctrine générale, le seul moyen de résoudre les apories théoriques est le retour à la vie ordinaire. C'est ce que fait Hume, non pas en renonçant à l'explication philosophique, mais en basculant des explications qui concernent l'ordre de la pensée et de l'imagination aux explications qui concernent la vie pratique. Hume retrouve ainsi la vie ordinaire lorsqu'il aborde la question du moi dans le tome II du Traité. Si l'on considère que la seconde analyse du moi doit se substituer à la première, en considérant les propos de Hume dans l'Appendice comme un argument supplémentaire pour opérer à cette substitution, on fait de Hume un sceptique radical. Ici encore, une comparaison entre Hume et Descartes nous semble fructueuse : alors que Descartes initiait les Méditations Métaphysiques avec la mise en œuvre du doute hyperbolique, Hume conclut le traité sur une crise sceptique. Le doute méthodique cartésien se conclut avec la découverte, à l'écart du cours ordinaire du monde, d'un principe indubitable, le cogito ; le doute affectif humien se résout par le passage à l'analyse de la vie ordinaire. ${ }^{12}$ L'affectivité du doute humien est comme transfusée dans le versant constructif du tome II du Traité,

12 «We have moved [...] from an 'I think' perspective to someone who holds a 'we do' (or social constructivist) perspective. Many problems of Hume interpretation come from the fact that Hume has both of these perspectives ; the link between them is Hume's science of man, which shows us how instinct saves us from the immobility that the 'I think' perspective would impose on us if we were primarily rational beings as Descartes and his followers maintained. Instinct supplies with the beliefs we have to have in order to think and act as members of society. The science of man, to provide this link, has to begin as individual psychology, and can only develop gradually into the more clearly social science that we find in book 3 and again in the second Enquiry » (Penelhum 1992, 283). Sur la difficulté de Hume à penser le self à l'écart d'autrui, voir aussi Garrett 1997, 163-86. 
quand le doute méthodique cartésien impulse le déploiement d'une connaissance théorique qui se tient fondamentalement à l'écart de toute affectivité. Alors que Hume considère la troisième notion primitive cartésienne, l'existence empirique de l'homme, comme le socle de sa propre philosophie, le problème de l'identité personnelle inhérent à la doctrine humienne est l'indice d'une réitération inversée de la rupture cartésienne entre la première et la troisième notion primitive. Alors que chez Hume la troisième devait permettre de rendre compte de la première, la troisième absorbe en fait la première sans être en mesure de lui accorder une place propre. Ce qui revient à dire qu'il y a un vide qui s'immisce dans la philosophie humienne, celui de l'identité personnelle du point de vue de la pensée et de l'imagination, qui aurait pu être une simple lacune si elle ne renvoyait pas à quelque chose d'aussi fondamental que la saisie de l'esprit par lui-même, autrement dit à ce qui constitue le principe même de toute théorie de la connaissance. Descartes assumait le vide théorique à propos de la spécificité de l'apparaître des phénomènes de l'union de l'âme et du corps, Hume prétend en faire le fondement de la connaissance théorique et retrouve malgré lui ce vide, mais cette fois en ce qui concerne la saisie de l'esprit par lui-même. La porosité humienne entre les passions et la raison se voit en quelques sortes abolie dans le traitement humien du problème de l'identité personnelle. La substitution du moi de la vie ordinaire au moi qui relève de la pensée et de l'imagination serait donc la matérialisation d'un scepticisme radical inhérent à la philosophie humienne car il est finalement ce qui motive le passage du tome I au tome II du Traité de la nature humaine.

\section{Conclusion}

Si Hume prône un scepticisme modéré qui serait le pendant de l'application de la méthode expérimentale aux sujets moraux, il nous semble qu'un scepticisme radical s'immisce dans son œuvre: les différentes versions du traitement du problème de l'identité personnelle sont, selon nous, l'indice d'une attitude fondamentalement sceptique qui motive la transition du tome I au tome II du Traité. De la nature humaine, on ne peut selon Hume connaître que les effets, et grâce à ces effets nous devrions être en mesure de comprendre les lois qui régissent les comportements humains. Néanmoins, l'identité personnelle du point de vue de la pensée et de l'imagination échappe à l'explication, et un autre point de vue aussi, celui de l'intérêt passionnel doit s'y substituer. Pour résoudre l'aporie du moi théorique, il faut en revenir au moi de la vie pratique. De la même manière, c'est la nature qui guérit la mélancolie qu'inspirent à Hume les contradictions de la raison, en le conduisant à se relâcher - à dîner, à faire une partie de jacquet, et à converser et se réjouir avec ses amis. 


\section{Bibliographie}

Ainslie, Don (2011). « Hume on Personal Identity ». Radcliffe, Elizabeth S. (ed.), A Companion to Hume. Malden (MA) : Wiley Blackwell, 140-56.

Ainslie, Don (2013). «Hume's Anti-Cogito ». Greco, Lorenzo; Vaccari, Alessio (eds), Hume Readings. Roma : Edizioni di storia e Letteratura, 91-120.

Alanen, Lily (2014). « Personal Identity, Passions, and the "True Idea of the Human Mind" ». Hume Studies, 40(1), 3-28.

Baxter, Don (1998). «Hume's Labyrinth Concerning the Idea of Personal Identity ». Hume Studies, XXIV, 203-33.

Benoist, Jocelyn (2003). «Le naturalisme, avec ou sans le scepticisme? Après Hume ». Revue de métaphysique et de morale, 38(2), 127-44.

Brahami, Frédéric (2003). Introduction au "Traité de la nature humaine" de David Hume. Paris: Presses universitaires de France. Quadrige.

Descartes, René (1989). «Lettre à Elisabeth, 28 juin 1643 ». Correspondance avec Elisabeth et autres lettres. Introd., bibliographie et chronologie de Jean-Marie Beyssade et Michelle Beyssade. Paris : Flammarion.

Garrett, Don (1997). Cognition and Commitment in Hume's Philosophy. New York; Oxford: Oxford University Press.

Garrett, Don (2006). « Hume's Naturalistic Theory of Representation ». Synthese, 152, 301-19.

Glauser, Richard (1996). «Pourquoi Hume était-il insatisfait de sa théorie de l'identité personnelle? ». Cahiers de philosophie, série A, fascicule VI, 11-34.

Hume, David (2015). Dissertation sur les passions. Traité de la nature humaine, Des passions, Traité de la nature Humaine, vol. 2. Trad. et présentation par Jean-Pierre Cléro, dossier par Raphaël Ehrsam. Paris : Flammarion.

Hume, David (2006). Enquête surl'entendement humain. Trad. par André Leroy, revue par Michelle Beyssade, présentation, notes, bibliographie (revue par P. Saltel) et chronologie par Michelle Beyssade. Paris : Flammarion.

Hume, David (2002). «Enquête sur les principes de la morale ». Appendice III, Hume, David, Essais et Traités sur plusieurs sujets, Enquête sur les principes de la morale, Histoire naturelle de la religion. Introduction, traduction et notes par Michel Malherbe. Paris: Vrin, 159.

Hume, David (1995). L'entendement. Traité de la nature humaine, Livre I et Appendice. Traduction par Philippe Baranger et Philippe Saltel; présentation, notes, index, bibliographie et chronologie par Philippe Saltel. Paris : Flammarion.

Jaffro, Laurent (2011). "Le sceptique humien est-il modéré ? Le rôle du pyrrhonisme dans la genèse causale du scepticisme mitigé ». $\Delta a ́ t \mu \omega v$. Revista Internacional de Filosofía, 52, 53-69.

Locke, John (2009). Essai sur l'entendement humain. Trad. par Pierre Coste; établissement du texte, présentation, dossier et notes par Philippe Hamou. Paris : Le Livre de Poche. Classiques de la Philosophie.

Malherbe, Michel (2016). La philosophie empiriste de David Hume. Paris : Vrin.

Kemp Smith, Norman (1966). The Philosophy of David Hume. London : MacMillan.

Pears, David F. (1975). « Hume's Account of Personal Identity ». Pears, David F., Questions in The Philosophy of Mind. London: Gerald Duckworth and Co. Ltd, 15-26.

Penelhum, Terence (1992). "The self of Book 1 and the selves of Book 2 ». Hume Studies, XVIII(2), 281-92. 
Douzant

Naturalisme et scepticisme : le problème de l'identité personnelle chez David Hume

Salaün, Franck (2003). Hume. L'identitépersonnelle. Paris : Presses universitaires de France. Philosophies.

Stroud, Barry (2016). «Naturalism and Skepticism in the Philosophy of Hume ». Russel, Paul (ed.), The Oxford Handbook of Hume. Oxford : Oxford University Press, 21-31. 


\title{
Nel tempo e nello spazio. Linguaggio e natura nella filosofia di Ludwig Wittgenstein
}

\author{
Alice Morelli \\ Università Ca' Foscari Venezia, Italia
}

\begin{abstract}
The paper focuses on some naturalistic aspects of Wittgenstein's later philosophy. Wittgenstein has often been considered a radical anti-naturalist philosopher, mainly because he does not endorse the thesis of the continuity between philosophy and science. However, it will be argued that Wittgenstein's later philosophy incorporates a kind of naturalism without naturalization, i.e., a liberal naturalism, in virtue of the relation between human nature and language. It will be concluded that Wittgenstein's liberal naturalism provides an example of a naturalistic perspective on language which avoids the limits of an intellectualist approach without leading to scientism: this is meant to express the irreducibility of naturalism to the mere scientific version.
\end{abstract}

Keywords Wittgenstein. Naturalism. Naturalization. Language. Nature.

Sommario 1 Introduzione. - 2 Wittgenstein antinaturalista. - 3 Wittgenstein naturalista. - 3.1 La svolta antropologica. - 3.2 Linguaggio e forma di vita. - 3.3 Fatti generalissimi della natura. - 3.4 Due sensi di 'natura'. - 4 Natura e concetti. - 5 Conclusione: naturalismo senza naturalizzazione.

\section{Introduzione}

Ludwig Wittgenstein è comunemente riconosciuto come uno dei più importanti filosofi del Novecento, eppure la sua filosofia non sembra avere particolare influenza nel contesto filosofico analitico contemporaneo, in quanto costituisce spesso oggetto esclusivo di dibattiti specifici ed esegetici che

\section{Philosophica 4}

e-ISSN 2610-8925 | ISSN 2610-8933

ISBN [ebook] 978-88-6969-325-0 | ISBN [print] 978-88-6969-326-7 
coinvolgono esclusivamente filosofi di orientamento wittgensteiniano. Paolo Tripodi (2009) sostiene che, da un punto di vista storico, la filosofia wittgensteiniana ha subito un calo di interesse nel panorama della filosofia analitica anglo-americana a partire dalla seconda metà del Novecento principalmente a causa del fatto che il pensiero di Wittgenstein manifesta una tendenza antinaturalista, ovvero una tendenza molto distante dal naturalismo scientifico come definito e istituzionalizzato da Quine (1969) nel celebre saggio Epistemology Naturalized.

Il punto non è tanto che le convinzioni ideologiche (o religiose) di Wittgenstein fossero controcorrente, quanto che la sua attività filosofica lo fu, perché non riuscì ad affrontare in maniera del tutto soddisfacente due questioni fondamentali, distinte ma correlate [...]: quale forma abbia e quale posto occupi la conoscenza scientifica nel paesaggio intellettuale contemporaneo, da una parte, e se la filosofia debba essere una specie di teoria, dall'altra parte. (Tripodi 2009, 432)

Il carattere espressamente a-teorico dell'indagine wittgensteiniana, unitamente ad una concezione della filosofia come un'attività distinta dalla scienza, hanno portato numerosi filosofi analitici ad etichettare la filosofia wittgensteiniana come profondamente antinaturalista, e a considerarla troppo obsoleta ed inadeguata rispetto lo spirito del tempo. Questo spirito deve la propria fisionomia allo sviluppo delle scienze cognitive e caratterizza un tipo di filosofia sempre più proiettata verso un dialogo proficuo con la scienza; un dialogo che, se portato alle estreme conseguenze, comporta un annullamento della distinzione tra l'impresa filosofica e l'impresa scientifica. Allo stesso tempo, tuttavia, se guardiamo alla letteratura secondaria su Wittgenstein a partire dagli anni Ottanta del secolo scorso, troviamo numerosi tentativi di fornire una lettura naturalistica del suo pensiero sulla base dei numerosi riferimenti alla natura umana e alla natura in generale che costellano gli scritti della produzione successiva al Tractatus logico-philosophicus (Conway 1989; McGinn 1984; Putnam 1998). ${ }^{1}$ La letteratura critica, dunque, ci offre complessivamente l'immagine di Wittgenstein come di un filosofo radicalmente antinaturalista, ma allo stesso tempo naturalista, poiché gran parte delle osservazioni appartenenti alla seconda fase del suo pensiero presentano numerosi tentativi di attirare la nostra attenzione su un certo nesso tra le nostre particolari formazioni concettuali e alcuni fatti generali della nostra natura, e dell'ambiente circostante. Questa caratterizzazione apparentemente ossimorica deriva, in parte, da determi- 
nate assunzioni circa la definizione del naturalismo filosofico e, in particolare, da una tendenza a ridurre il naturalismo al solo naturalismo scientifico come sviluppatosi nella seconda metà del Novecento.

Con il presente contributo intendo esporre alcuni aspetti della filosofia del 'secondo Wittgenstein' al fine di suggerire un ripensamento del suo rapporto con il naturalismo e fornire un esempio di varietà di naturalismo senza naturalizzazione, mostrando quindi l'irriducibilità del naturalismo filosofico al solo naturalismo scientifico. ${ }^{2}$ In primo luogo, cercherò di chiarire l'antinaturalismo di Wittgenstein mostrandone la natura parziale. Questo permetterà di specificare, inoltre, come il termine 'naturalismo' verrà impiegato nel presente lavoro. Successivamente, illustrerò quelli che ritengo essere aspetti naturalistici della filosofia del 'secondo Wittgenstein' attraverso l'esposizione delle sue osservazioni sul legame tra linguaggio e natura. Mi soffermerò sull'impiego del concetto di natura e sul ruolo che Wittgenstein attribuisce alla natura, ovvero il tipo di nesso instaurato tra natura umana e concetti. Concluderò che, nonostante Wittgenstein possa essere legittimamente considerato avversario del naturalismo scientifico, la sua filosofia tarda può essere considerata esempio di un naturalismo liberale, caratterizzabile nei termini di una prospettiva anti-intellettualista e non razionalista sul linguaggio.

\section{Wittgenstein antinaturalista}

È ormai un luogo comune della filosofia il riconoscimento del fatto che «il naturalismo significa molte cose diverse per molte persone differenti» (Boniolo 2006, 100). Il termine 'naturalismo', infatti, è un termine polisemico. Laudisa (2014) suggerisce di utilizzare la nozione wittgensteiniana di somiglianza di famiglia per indicare l'apertura di tale concetto: non esiste una definizione precisa e universalmente accettata di naturalismo, ma piuttosto un'ampia rete di concetti imparentati tra loro che danno vita ad un clima filosofico più che ad una teoria strutturata. L'antinaturalismo di Wittgenstein è qui presentato in opposizione ad un tipo di naturalismo scientifico che caratterizzo ulteriormente come epistemologico e identifico nella tesi quiniana della continuità tra filosofia e scienza. Wittgenstein è un avversario del naturalismo epistemologico perché distingue nettamente, sia nel Tractatus, sia nelle fasi successive della sua produzione, tra filosofia e scienza. Esse devono considerarsi ambiti diversi non solo nel metodo, ma anche nell'oggetto e negli scopi. Come suggerito

2 Recentemente, il tema in oggetto è particolarmente sentito dalla comunità wittgensteiniana ed è affrontato con l'obiettivo di rivalutare la collocazione di Wittgenstein nell'era della naturalizzazione. Si vedano in proposito Cahill, Raleigh 2018; Beale, Kidd 2017. 
da Glock $(2008,161)$, può essere utile istituire una distinzione tra il metodo filosofico di Wittgenstein e la sua ideologia personale. La distinzione tra filosofia e scienza costituisce così una ragione metodologica dell'antinaturalismo ed emerge dai passi in cui Wittgenstein espone la propria concezione dell'impresa filosofica. ${ }^{3}$

Lo scopo della filosofia è il rischiaramento logico dei pensieri. La filosofia è non una dottrina, ma un'attività. (TLP 4.112)

La filosofia si limita, appunto, a metterci tutto davanti, e non spiega e non deduce nulla. - Poiché tutto è lì in mostra, non c'è neanche nulla da spiegare. Ciò che è nascosto non ci interessa. (PI § 126)

Mentre la scienza è una dottrina che ha per oggetto alcuni fatti del mondo e si pone come obiettivo la spiegazione di tali fatti ricorrendo all'elaborazione di teorie come strumenti di indagine delle cause dei fenomeni, la filosofia è un'attività che descrive gli usi effettivi delle parole del nostro linguaggio e si pone come obiettivo la rappresentazione perspicua della logica del linguaggio per dissolvere i fraintendimenti concettuali; essa, lungi dal voler indagare le cause, fornisce semmai le ragioni di determinate pratiche linguistiche.

Le ragioni ideologiche dell'antinaturalismo di Wittgenstein riguardano il suo complesso rapporto con la scienza del proprio tempo (Andronico 2010, 83-4; Glock 2008, 161). Da un lato egli attribuisce un ruolo importante alla scienza nella comunità considerandola, insieme all'educazione, una componente fondamentale della nostra forma di vita (OC § 298), dall'altro lato egli scrive affermazioni molto polemiche sullo spirito del proprio tempo, che ritiene essere caratterizzato dal mito del progresso e da una certa idolatria nei confronti della scienza stessa.

Essere capito ed apprezzato dal tipico uomo di scienza occidentale non mi importa affatto, perché costui non capisce lo spirito con cui scrivo. La nostra cultura è caratterizzata dalla parola «progresso». Il progresso è la sua forma, non una delle sue proprietà, quella di progredire. Essa è tipicamente costruttiva. La sua attività consiste nell'erigere qualcosa di sempre più complesso. E anche la chiarezza serve a sua volta solo a questo scopo, non è fine a sé stessa. Per me, al contrario, la chiarezza, la trasparenza sono fini a sé stesse. (CV 27-28)

3 Per le abbreviazioni delle opere di Wittgenstein si veda la sezione 'Abbreviazioni'. Le citazioni nel corpo del testo riportano sigla dell'opera di riferimento e numero di pagina, oppure numero del paragrafo. Laddove si tratti di paragrafi, i numeri sono preceduti dal simbolo ' $\S$ '. 
Wittgenstein non intende negare valore conoscitivo alla scienza, quanto metterci in guardia di fronte a due tendenze ritenute fonte di confusione filosofica: l'atteggiamento che vede nella scienza l'unica fonte di conoscenza, e la tendenza da parte dei filosofi a imitare i metodi degli scienziati. ${ }^{4}$

I filosofi hanno sempre davanti agli occhi il metodo della scienza, ed hanno l'irresistibile tentazione di porre domande, e di rispondere alle domande, nello stesso modo in cui lo fa la scienza. Questa tendenza è la reale fonte della metafisica, e porta il filosofo nell'oscurità completa. Ma il nostro compito non può mai essere quello di ridurre qualcosa a qualcosa, o di spiegare qualcosa. La filosofia è, in realtà, 'puramente descrittiva'. (BB 28)

Alla luce di quanto sostenuto finora, la filosofia wittgensteiniana costituisce effettivamente un esempio di filosofia antinaturalista a patto di specificare che si tratta di un antinaturalismo scientifico, ovvero una prospettiva filosofica che non ammette e, anzi, critica, le assunzioni proprie del naturalismo scientifico epistemologico. L'attribuzione di un antinaturalismo radicale, infatti, si basa a ben vedere su due assunzioni problematiche: 1 . Un'indebita identificazione del naturalismo filosofico con il naturalismo scientifico. Partendo da tale presupposto, una determinata filosofia viene considerata a pieno titolo naturalista solo se conforme ai caratteri del naturalismo scientifico e, di conseguenza, tutto ciò che si distanzia da questo determinato approccio viene considerato intrinsecamente antinaturalista. 2. Una semplificazione delle indicazioni metodologiche che Wittgenstein offre nei propri scritti. Se da un lato Wittgenstein sostiene fermamente la separazione filosofia-scienza e scrive contro lo spirito scientista del proprio tempo, dall'altro lato nella seconda fase del suo pensiero traccia i contorni di un particolare metodo filosofico, definito morfologico, o comparativo, che egli deriva dalle letture dei pensatori naturalisti Goethe e Spengler (Andronico 1998). Le osservazioni metodologiche, dunque, non si limitano alla critica della tesi della continuità filosofia-scienza, ma comprendono anche una pars construens, ovvero la proposta di un metodo adatto alla ricerca filosofica che, come vedremo, è uno degli elementi centrali della prospettiva naturalistica che caratterizza la filosofia tarda di Wittgenstein. La prima assunzione problematica, dunque, si basa su un mancato riconoscimento della varietà del naturalismo filosofico, che emerge sia da considerazioni concettuali, sia da considerazioni storiche: anche nella filosofia contemporanea, difendere una posizione naturalista

4 I bersagli specifici della critica wittgensteiniana possono essere identificati nella figura di Russell e nell'ideale neopositivista di una filosofia scientifica. 
non comporta aderire in toto al progetto quiniano. Strawson distingue due tipi di naturalismo contemporaneo: il naturalismo scientifico, o riduzionista, e il naturalismo liberale (Strawson 1985, 1). Nella seconda categoria rientrano prospettive filosofiche che si distanziano da posizioni intellettualiste e prendono in considerazione l'essere umano anche a partire dalla sua natura animale, ma impiegano un concetto di natura più esteso rispetto ai sostenitori del naturalismo scientifico. Inoltre, sebbene si riconosca l'importanza delle acquisizioni della scienza per la riflessione filosofica, non si accetta la tesi forte secondo cui la scienza è, o dovrebbe essere, l'unica guida autentica sulle questioni di metodo, ontologia, conoscenza e semantica. ${ }^{5}$

The fact that [the term 'naturalism'] has been applied to the work of philosophers having as little in common as Hume and Spinoza is enough to suggest that there is a distinction to be drawn between varieties of naturalism. (Strawson 1985, 1)

Il fatto che [il termine 'naturalismo'] sia stato applicato alle opere di filosofi che hanno poco in comune tra loro come Hume e Spinoza è sufficiente per suggerire che occorre istituire una distinzione tra varietà di naturalismo. (trad. dell'Autore)

La seconda assunzione problematica può essere affrontata illustrando quegli aspetti della filosofia di Wittgenstein che suggeriscono l'utilità di un ripensamento del suo rapporto con il naturalismo, in particolare alla luce della prospettiva contemporanea naturalizzante che incentiva uno studio empirico del linguaggio di contro ad un tipo di indagine concettuale. È possibile fornire un contributo prettamente filosofico, non scientifico, sul tema del linguaggio che pur faccia uso dei riferimenti alla natura degli esseri umani ma che non comporti l'identificazione tra filosofia e scienza? Intendo rispondere affermativamente mostrando come la filosofia di Wittgenstein possa costituirne un esempio.

\section{Wittgenstein naturalista}

Come è stato riconosciuto dai critici (McGinn 2010; Strawson 1985; Cahill, Raleigh 2018), l'elemento naturalistico permea l'intera produzione del 'secondo Wittgenstein' e può essere ricavato anche solo guardando al suo stile filosofico, ovvero al modo in cui Wittgenstein affronta e 'dissolve' alcuni tradizionali nodi filosofici, come il problema del linguaggio privato, la non referenzialità del vocabolario psicologi- 
co-esperienziale, o il problema del fondamento delle pratiche linguistiche e sociali. Tuttavia, in questa sede proverò ad adottare un punto di vista più generale presentando la 'nuova' prospettiva sul linguaggio e sul significato espressa nelle Ricerche Filosofiche. ${ }^{6}$ Prenderò, dunque, in considerazione il contributo di Wittgenstein alla filosofia del linguaggio e non approfondirò il legame che tale prospettiva intrattiene con alcuni temi della filosofia della mente contemporanea. ${ }^{7}$

\subsection{La svolta antropologica}

Nelle Ricerche, Wittgenstein presenta una serie di osservazioni sul linguaggio e sul significato che possono essere lette complessivamente come espressioni di una 'svolta antropologica' in filosofia del linguaggio: 'svolta', poiché tale prospettiva è presentata in contrasto con le idee precedentemente esposte nel Tractatus; 'antropologica', poiché si assiste ad una antropologizzazione della nozione di significato, ovvero l'idea secondo cui c'è un senso in cui il nostro operare con le parole dipende anche da come siamo fatti, dal tipo di esseri che siamo e dal tipo particolare di addestramento cui possiamo sottoporci. Tale svolta potremmo dunque definirla come un cambio di prospettiva secondo cui il linguaggio non è meramente un'attività governata da regole, ma un'attività prettamente umana. Questo significa non solo che la fisionomia del linguaggio non può non essere influenzata in qualche misura dalle caratteristiche dei soggetti che lo condividono, ma che il linguaggio stesso è meglio caratterizzabile nei termini di una attività da sempre incarnata nel mondo (PI § 23).

Ma se si tratta di una svolta, quale 'vecchia' concezione del linguaggio costituisce il bersaglio critico di Wittgenstein? Il modo di guardare al linguaggio da cui Wittgenstein intende prendere le distanze è esempio di una tendenza filosofica che ritiene essere estremamente comune: il dogmatismo. Il filosofo dogmatico scambia il termine di confronto, utile e illuminante per la particolare ricerca svolta, con il modello a cui tutto deve conformarsi (PI § 130). Utilizzando una metafora wittgensteiniana, potremmo dire che il filosofo confonde la realtà con gli occhiali attraverso cui la guarda (PI § 114). Un esempio concreto lo troviamo proprio nel Tractatus. In quest'opera, Wittgenstein ci presenta una teoria della proposizione denominata picture theory, ovvero una teoria della proposizione come immagine: una proposizione è un'immagine che raffigura uno stato di cose possibile (Mounce 2000). Nelle Ricerche, Wittgenstein sembra dirci che può essere utile paragonare una proposizione ad un'immagine per chiarire il funzionamento del

7 Mi limito a segnalare Williams 1999 e Moyal-Sharrock 2013. 
linguaggio e, in particolare, delle proposizioni dichiarative. Tuttavia, il filosofo dogmatico non si accontenta di questo termine di paragone e impiega tale confronto per elaborare una teoria della proposizione: egli afferma non solo che tutte le proposizioni sono immagini, ma che la natura rappresentativa della proposizione costituisce l'essenza del linguaggio, essenza che va dunque colta grazie ad un processo di analisi. In questo senso, il dogmatismo incorpora altre due tendenze filosofiche: il desiderio di generalità e un essenzialismo secondo cui l'essenza è, per definizione, un qualcosa di nascosto (PI §§ 92, 97, 103, 107, 113). Il modo di fare filosofia dogmatico indaga il linguaggio considerandolo in astratto, come una costruzione fuori dallo spazio e dal tempo, dunque estrapolandolo dalla vita degli uomini. Contro il dogmatismo, Wittgenstein suggerisce in primo luogo un cambiamento di prospettiva incentrato sulla nozione di grammatica. Nonostante egli impieghi il termine 'grammatica' in vari modi, qui interessa la grammatica intesa come attività filosofica che descrive l'uso delle parole ovvero, secondo la prospettiva delle Ricerche, il loro significato. Potremmo parlare dunque di una 'svolta grammaticale' che è concettualmente distinta dalla 'svolta antropologica' e che si riassume nell'idea secondo cui la chiarezza della logica del linguaggio non debba essere cercata in un altro linguaggio diverso da quello ordinario - che sia questo il linguaggio ideale della logica, o il linguaggio primario della fenomenologia -, ma nel linguaggio comune che parliamo tutti i giorni.

Quanto più rigorosamente consideriamo il linguaggio effettivo, tanto più forte diventa il conflitto tra esso e le nostre esigenze. (La purezza cristallina della logica non mi si era affatto data come un risultato; era un'esigenza). Il conflitto diventa intollerabile; l'esigenza minaccia a questo punto di trasformarsi in qualcosa di vacuo. - Siamo finiti su una lastra di ghiaccio dove manca l'attrito e perciò le condizioni sono in un certo senso ideali, ma appunto per questo non possiamo muoverci. Vogliamo camminare; dunque abbiamo bisogno dell'attrito. Torniamo sul terreno scabro. (PI § 107)

Il linguaggio oggetto dell'indagine filosofica non è un qualcosa al di fuori dello spazio e del tempo, ma un fenomeno spazio-temporale la cui analisi deve riguardare soprattutto le situazioni concrete del suo uso, ovvero come gli uomini impiegano le parole.

Parliamo del fenomeno spazio-temporale del linguaggio; non di una non-cosa fuori dello spazio e del tempo [...]. La domanda «Che cos'è, propriamente, una parola?» è analoga alla domanda: «Che cos'è un pezzo degli scacchi?». (PI § 108) 


\subsection{Linguaggio e forma di vita}

Una delle nozioni chiave della prospettiva grammaticale di Wittgenstein è quella di regola. All'inizio delle Ricerche, Wittgenstein suggerisce di caratterizzare il significato di un'espressione linguistica come l'uso di tale espressione nel linguaggio, ovvero come l'insieme delle regole che ne governano l'impiego (PI § 43). La 'svolta antropologica' costituisce una sorta di ampliamento della prospettiva grammaticale: Wittgenstein sembra dirci che non basta riconoscere i limiti del modello denotativo del linguaggio e caratterizzare il significato come uso, se per uso intendiamo un insieme definito e chiuso di regole fisse ed esplicite (PI § 81), ma occorre rilevare il nesso tra questo uso e la vita degli uomini che lo impiegano. «Immaginare un linguaggio significa immaginare una forma di vita» (PI § 19). Le osservazioni sul seguire una regola (PI §§ 185241) mostrano che seguire una regola è una prassi, ma il termine 'prassi' è un termine molto ricco nella prospettiva wittgensteiniana: dire che seguire una regola è una prassi significa affermare che, per l'appunto, non è meramente una questione di calcoli ed elenchi di istruzioni esplicite. Le espressioni 'regola' e 'seguire una regola' si riferiscono ad una tecnica appresa e incorporata, ad un'abitudine, istituzione intersoggettivamente accettata e collocata in un contesto che è un'intera forma di vita, ovvero un sistema caratterizzato sia da una cultura, sia da alcune caratteristiche specie specifiche degli uomini (PI § 199).

L'espressione 'forma di vita' compare nelle Ricerche solo cinque volte; non è un'espressione tecnica e precisa, ma presenta un'interessante oscillazione semantica che fa emergere la complessità del riferimento wittgensteiniano alla natura (PI 230, 295, §§ 19, 23, 241). Nel paragrafo 23 Wittgenstein impiega questa espressione insieme a quella di 'attività' per sottolineare il carattere prassiologico del linguaggio, vale a dire per alludere al fatto che, nelle parole di Voltolini $(2009,40)$ «l'uso del linguaggio non è l'impiego che ne fa un soggetto disincarnato, bensì è l'uso che ha luogo in un contesto di attività e consuetudini il cui carattere è eminentemente sociale». Nello stesso paragrafo Wittgenstein presenta un elenco di giochi linguistici ed attività che appartengono al sistema culturale.

Qui la parola 'gioco linguistico' è destinata a mettere in evidenza il fatto che il parlare un linguaggio fa parte di un'attività, o di una forma di vita. [...] comandare, e agire secondo il comando Descrivere un oggetto in base al suo aspetto o alle sue dimensioni - Costruire un oggetto in base a una descrizione (disegno) - Riferire un avvenimento - Far congetture intorno all'avvenimento - Elaborare un'ipotesi e metterla alla prova - Rappresentare i risultati di un esperimento mediante tabelle e diagrammi - Inventare una storia; e leggerla [...] chiedere, ringraziare, imprecare, salutare, pregare. (PI § 23) 
In altri passi, invece, Wittgenstein impiega l'espressione per indicare un insieme di comportamenti e aspetti della vita umana considerata come una vita specie-specifica; questi comportamenti sono trasversali alle culture e riguardano attività basilari degli esseri umani, come il mangiare e il riprodursi (PI § 25; RFM V §§ 2, 15).

Il comandare, l'interrogare, il raccontare, il chiacchierare, fanno parte della nostra storia naturale come il camminare, il mangiare, il bere, il giocare. (PI § 25)

Instaurando un nesso tra linguaggio e forma di vita, Wittgenstein intende mostrare che comprendiamo i concetti se guardiamo non soltanto al loro uso inteso come insieme di regole, ma se consideriamo anche le conseguenze del loro impiego sulla vita delle persone che se ne servono. In questo modo si ricava un'immagine del linguaggio come fin dall'inizio radicato nel mondo, come uno degli aspetti costitutivi dell'agire che caratterizza il modo di vivere specifico della specie umana (OC § 475). Le forme di vita, o i fatti della vita, sono il dato che il filosofo deve accettare e prendere in considerazione; sono il dato che funge da termine ultimo della catena delle giustificazioni delle pratiche linguistiche.

Quello che, in filosofia, dobbiamo accettare, il dato [...] sono i fatti della vita [...] il fatto che agiamo in questo e questo modo, che, ad esempio, puniamo certe azioni, accertiamo la situazione effettiva in questo e questo modo, diamo ordini, prepariamo resoconto, descriviamo colori, ci interessiamo ai sentimenti altrui. (RPP I § 630)

\subsection{Fatti generalissimi della natura}

È all'interno di questo contesto che Wittgenstein assegna molta importanza ad alcuni fatti generali della natura e al nesso tra tali fatti e il linguaggio in dotazione. Wittgenstein ci chiede di immaginarci situazioni logicamente possibili in cui però aspetti significativi della nostra natura, o della natura circostante, sono diversi da come di fatto sono. Troviamo un ricco elenco di tali fatti nel paragrafo 47 delle Osservazioni sulla filosofia della psicologia:

È importante il fatto che noi abbiamo la consuetudine di disegnare con matite, penne o cose del genere, e che perciò gli elementi della nostra rappresentazione siano righe e punti (nel senso di 'puntini'). Se gli uomini avessero sempre dipinto e non disegnato (se quindi il concetto di contorno delle forme non avesse un ruolo molto importante), se ci fosse una parola in uso, diciamo "linea", che nessuno associasse nel pensiero ad una riga, dunque a qual- 
cosa di molto sottile, bensì la associasse sempre e solo al confine tra due colori, forse alcuni sviluppi della geometria non avrebbero avuto luogo. Se noi vedessimo uno dei nostri colori primari, diciamo il rosso, solo rarissimamente, solo in dimensioni ridottissime, se non fossimo in grado di produrre colori per dipingere, se il rosso apparisse soltanto in determinate combinazioni con altri colori, ad esempio solo sulla punta delle foglie di certi alberi, che in autunno gradualmente si trasformano da verdi in rossi, niente verrebbe più naturale che chiamare il rosso un verde degenerato. Pensa alle circostanze in cui bianco e nero ci appaiono come colori e a quelle in cui essi ci appaiono come assenza di colore. Metti che fosse possibile lavar via tutti i colori, così che la base fosse sempre bianca, e non ci fosse una tinta bianca. Ci è più facile riprodurre e riconoscere grazie alla memoria un rosso puro, un verde, ecc., che poniamo, una tonalità di bruno rossiccio. (RPP I § 47)

Per ogni esempio riportato Wittgenstein suggerisce una forma di legame tra questi fatti generali e i comuni giochi linguistici degli uomini: queste osservazioni suggeriscono circostanze in cui la rete concettuale con cui leggiamo il mondo sarebbe stata diversa da quella che di fatto abbiamo, in concomitanza con diverse caratteristiche sia della natura e dell'uomo come specie specifica, sia delle abitudini dell'uomo inteso come membro di una determinata cultura. Ė importante specificare però che i fatti naturali ai quali Wittgenstein fa riferimento non sono solamente le situazioni ipotetiche e i casi immaginari, ma le stesse pratiche linguistiche comunemente adottate; esse costituiscono quel terreno scabro che ci offre l'attrito sufficiente per poterci liberare da immagini fuorvianti sedimentate nel linguaggio stesso e nel modo di fare filosofia dogmatico.

\subsection{Due sensi di 'natura'}

Abbiamo visto che tra i fatti della vita e i fatti generali della natura troviamo sia abitudini apprese, tratti culturali, sia tratti specie-specifici degli esseri umani, appartenenti alla loro natura biologica e prelinguistica. Wittgenstein quando parla del comportamento umano prende in considerazione, non sempre specificandone la differenza, sia le componenti istintive e biologiche, sia le componenti apprese.

Del comportamento degli uomini, ovviamente, non fa parte soltanto ciò che essi fanno senza avere appreso alcun modo di comportarsi, ma anche ciò che fanno (dunque, ad esempio, anche ciò che dicono) dopo essere stati addestrati in una determinata maniera. (RPP I § 131) 
In Wittgenstein, infatti, troviamo un'interessante estensione del concetto di naturale: egli considera naturale non solo ciò che è innato e specie-specifico, ma anche ciò che è stato appreso ed è divenuto naturale dopo un lungo periodo di esercizio. Wittgenstein impiega entrambi i sensi del termine nel seguente paragrafo:

Se insegniamo ad un uomo questa tecnica così e così per mezzo di esempi, - cosicché, in un determinato caso nuovo procede così e non così, o in un certo caso s'arresta, perché questa e non quella è per lui la prosecuzione "naturale", questa cosa, di per se stessa, è già un fatto naturale estremamente importante. (Z § 355)

L'addestrabilità dell'essere umano è uno dei fatti della natura che Wittgenstein intende prendere in considerazione nella sua indagine concettuale e che permette all'essere umano per natura (primo senso) di trovare naturale (secondo senso) ciò che in realtà acquisisce con l'esercizio. Se da un lato, dunque, Wittgenstein è interessato a mettere in luce le componenti naturali nel senso di prelinguistiche che stanno alla base dei giochi linguistici, dall'altro lato insiste con ugual forza a mettere in luce il ruolo svolto dall'addestramento nell'acquisizione dei concetti.

Noi siamo abituati a una determinata classificazione delle cose. Insieme alla lingua, o alle lingue, è divenuta per noi natura. (RPP II § 678; corsivo aggiunto)

\section{$4 \quad$ Natura e concetti}

Con le nozioni di forma di vita e fatto della natura, Wittgenstein intende mettere in rilievo un certo legame tra il nostro essere uomini collocati in un determinato spazio in un determinato tempo, e il linguaggio in dotazione. Questa è la ragione principale per cui la sua filosofia sembra incorporare una certa forma di naturalismo (McGinn 2010, 322). Abbiamo già visto come in Wittgenstein ci sia un complesso riferimento alla natura umana che porta ad un'estensione del concetto di naturale: naturale è anche ciò che, pur non essendo innato e biologico, diviene naturale in quanto appreso e incorporato ad un livello basico del nostro agire. Per poter caratterizzare ulteriormente il naturalismo in questione, tuttavia, occorre chiarire anche il ruolo che Wittgenstein assegna alla natura, ovvero il tipo di nesso che egli instaura tra i fatti generali della natura e i concetti. Si potrebbe infatti pensare che tale nesso consista in un rapporto di determinazione.

Dunque è come se i nostri concetti, come se l'impiego delle nostre parole fossero condizionati da un'armatura di fattualità. (RPP § 190) 
La filosofia è allora una forma di storia naturale o etnografia? Alcuni critici, in effetti, hanno interpretato i luoghi esposti in precedenza in ottica fondazionale e hanno attribuito a Wittgenstein un interesse forte per il dato naturale in sé: il presunto naturalismo di Wittgenstein viene caratterizzato come un tentativo di trovare un fondamento naturalistico al nostro linguaggio (Conway 1989, McGinn 1984, MoyalSharrock 2004). I fatti su cui Wittgenstein pone l'attenzione sarebbero fatti che determinano il significato delle parole. Questa prospettiva ci rimanda un'immagine di Wittgenstein come di un filosofo interessato a identificare le cause dei nostri concetti, quindi come un filosofo impegnato in una ricerca empirico-fattuale sul linguaggio umano. Tuttavia, in primo luogo, occorre osservare che Wittgenstein stesso nega esplicitamente l'identificazione tra la propria filosofia e l'etnografia.

Se adottiamo la prospettiva etnologica, vuol dire forse che identifichiamo la filosofia con l'etnologia? No, vuol dire solo che spostiamo il nostro punto di vista molto al di fuori, per poter vedere le cose più obbiettivamente. (CV 78)

In secondo luogo, come si può evincere dalla citazione precedente, la prospettiva antropologica ha un ruolo metodologico, ovvero è al servizio dell'attività di chiarificazione concettuale della filosofia. Il riferimento ai fatti naturali e l'impiego di casi immaginari sono parte di un metodo filosofico, definito comparativo, o morfologico, che Wittgenstein ricava dalle letture di Goethe e Spengler (Andronico 1998). Tale metodo è una strategia comparativa con cui l'analisi del linguaggio si costruisce partendo dall'analisi di porzioni limitate di linguaggio che vengono confrontate tra di loro per far emergere le regole che governano l'impiego delle parole. Al termine del confronto tra i casi particolari arriviamo a riconoscere quelle forme di espressione che già impieghiamo, ma sul cui uso non abbiamo le idee chiare, proprio perché siamo noi stessi ad impiegarle regolarmente (CV 41). Il metodo morfologico permette di rispettare il principio anticausalista dell'analisi logico-grammaticale in virtù del quale in filosofia «non si tratta di spiegare un gioco linguistico [...] ma di prendere atto di un gioco linguistico» (PI § 655), ovvero di trattarlo nella propria analisi come un «fenomeno originario» (PI § 654). L'impiego di numerosi casi immaginari, invece, risponde all'esigenza di osservare i nostri usi linguistici nonostante la nostra posizione interna al sistema, senza tuttavia uscirne. Permette una sorta di straniamento non metafisico. Wittgenstein ci sottopone numerosi casi immaginari per mettere in luce, per contrasto, ciò che facciamo noi.

Se la formazione dei concetti può essere spiegata ricorrendo a fatti naturali, allora, invece che alla grammatica, non dovremmo interessarci a ciò che, in natura, sta alla sua base? - Certamente ci 
interessa anche la corrispondenza dei concetti con fatti molto generali della natura (tali che per lo più non ci sorprendono a causa della loro generalità). Ma il nostro interesse non ricade su queste possibili cause della formazione dei concetti; noi non facciamo scienza naturale, e neanche facciamo storia naturale, - perché, per i nostri scopi, una storia naturale potremmo anche inventarla. Non dico: Se questi e questi altri fatti naturali fossero diversi da quelli che sono gli uomini avrebbero concetti diversi (nel senso di un'ipotesi). Ma: Chi crede che certi concetti siano senz'altro quelli giusti e che colui che ne possedesse altri non si renderebbe conto di quello di cui ci rendiamo conto noi, - potrebbe immaginare certi fatti generalissimi della natura in modo diverso da quello in cui siamo soliti immaginarli; e formazioni di concetti diverse da quelle abituali gli diventerebbero comprensibili. (PI § 299)

L'interesse di Wittgenstein non riguarda il dato naturale in sé, bensì il funzionamento dei concetti. Il carattere della filosofia wittgensteiniana rimane esclusivamente logico-grammaticale: il riferimento ai fatti naturali «è un modo non di fondare i concetti sui fatti, ma di comprendere come i nostri concetti operino» (Perissinotto 2010, 117). Wittgenstein non afferma che se i fatti naturali fossero diversi da quelli che sono allora i nostri concetti sarebbero diversi, ma piuttosto ci invita ad immaginare alcuni fatti generali della natura in modi diversi da quelli a cui siamo abituati per poter cogliere la contingenza del nostro sistema concettuale e per poter comprendere formazioni di concetti diversi dai nostri che saremmo tentati di etichettare aprioristicamente come incomprensibili, strani e magari innaturali.

\section{Conclusione: naturalismo senza naturalizzazione}

Nei paragrafi precedenti ho cercato di illustrare la prospettiva antropologica sul linguaggio adottata da Wittgenstein nelle Ricerche mettendo in luce da un lato l'impiego del concetto di naturale, e dall'altro lato il ruolo assegnato alla natura a partire dall'assunzione secondo cui la nostra formazione concettuale diviene comprensibile anche alla luce di certi fatti generali della natura dell'essere umano. Gran parte dell'attività filosofica, dunque, secondo Wittgenstein, consiste nel prendere atto di come noi, di fatto, impieghiamo alcuni termini ed espressioni, anche e soprattutto tenendo bene a mente il contesto naturale - nel senso di biologico e culturale - in cui queste pratiche si inseriscono e prendono vita. Questo approccio si distingue da un approccio di tipo intellettualista che, lungi dal riconoscere alcuni fatti propri dell'essere umano, prescrive un'analisi in profondità andando alla ricerca di ragioni ultime e nascoste dietro le attività che gli uomini comunemente compiono, tra cui appunto l'impiego del linguag- 
gio ordinario. I nostri concetti sono quelli che sono anche in virtù di un certo nostro modo di essere umani, e questa prospettiva è una delle possibili alternative ad un approccio razionalista secondo cui, per esempio, la rete concettuale che abbiamo è tale in virtù di stipulazioni prese a tavolino. L' atteggiamento filosofico anti-intellettualista sostituisce all'approccio razionalistico tradizionale un tipo di indagine in cui l'essere umano viene considerato a partire dalla propria natura animale. ${ }^{8}$ Questo, tuttavia, non equivale a sostenere la tesi forte di un nesso deterministico tra natura e concetti, e non equivale a identificare l'indagine propria del filosofo con l'indagine propria dell'uomo di scienza. L'antinaturalismo scientifico rimane e, anzi, è ulteriormente ribadito alla luce di questa prospettiva naturalistica liberale che può essere considerata ulteriore esempio di un tipo di naturalismo senza naturalizzazione, dunque elemento a favore dell'irriducibilità del naturalismo filosofico alla sola variante scientifica. La nostra grammatica, per Wittgenstein, non si fonda sulla natura; l'appello ad alcuni fatti della natura umana ha il ruolo di aiutare il filosofo nella chiarificazione dei nostri concetti partendo dall'assunzione che il nostro sistema concettuale non è indifferente al nostro essere noi.

\section{Abbreviazioni}

BT = The Big Typescript. Torino: Einaudi, 2002. (Big Typescript: TS 213. Ed. by C.G. Luckhardt and M. Aue. Oxford: Blackwell, 2005).

CV = Pensieri diversi. Milano: Adelphi, 2009. (Culture and Value. Ed. by G.H. Von Wright. Chicago: University of Chicago Press, 1984).

OC = Della certezza. L'analisi filosofica del senso comune. Torino: Einaudi, 1999. (On Certainty. Ed. by G.E.M. Anscombe, and G.H. Von Wright. Oxford: Blackwell, 1997).

$P G=$ Grammatica filosofica. Scandicci: La nuova Italia, 1990. (Philosophical Grammar. Ed. by R. Rhees; transl by A. Kenny. Oxford: Blackwell, 1974).

$\mathrm{PI}=$ Ricerche Filosofiche. Torino: Einaudi, 2009. (Philosophical Investigations, revised 4th edition. Ed. by P.M.S. Hacker, and Joachim Schulte; transl. by G.E.M. Anscombe et al. Oxford: Wiley-Blackwell, 2009).

RFM = Osservazioni sopra $i$ fondamenti della matematica . Torino: Einaudi, 1988. (Remarks on the Foundations of Mathematics 3rd revised edition. Edited by G.E.M. Anscombe et al.; transl. by G.E.M. Anscombe. Oxford: Blackwell, 1978). RPP I e II = Osservazioni sulla filosofia della psicologia. Milano: Adelphi, 1990. (Remarks on the Philosophy of Psychology. Ed. by G.E.M. Anscombe, and G.H. Von Wright; transl. by G.E.M. Anscombe. Oxford: Blackwell, 1980).

8 Alcuni autori hanno istituito un'analogia tra la prospettiva naturalistica di Wittgenstein e il naturalismo di Hume inteso come critica all'efficacia della ragione nell'impresa teorica contro lo scetticismo. Strawson $(1985,10)$ accosta i due filosofi sulla base di una comune strategia naturalistica contro lo scetticismo. Fogelin $(2009,23)$ sottolinea come entrambi assumano un atteggiamento anti-intellettualista in quanto limitano il ruolo dell'intelletto e fondano le capacità intellettuali degli uomini nella loro natura animale. 
TLP = Tractatus logico-philosophicus e Quaderni 1914-1916. Torino: Einaudi, 2009. (Tractatus Logico-Philosophicus. Transl. by D.F. Pears, and B.F. McGuinness. London: Routledge and Kegan Paul, 1961).

Z=Zettel. Torino: Einaudi, 2007. (Zettel. Ed. by G.E.M. Anscombe, and G.H.Von Wright; transl. by G.E.M. Anscombe. Berkeley: University of California Press, 1970).

\section{Bibliografia}

Andronico, Marilena (1998). Antropologia e metodo morfologico. Studio su Wittgenstein. Napoli: La città del sole.

Andronico, Marilena (2010). «Dall'interno dello schema: per un naturalismo ontologico non riduzionista». Rivista di estetica, 44, 81-96.

Beale, Jonathan; Kidd, Ian James (eds) (2017). Wittgenstein and Scientism. London: Routledge.

Boniolo, Giovanni (2006). «Naturalizziamo? Ma con saggezza». Costa, Paolo; Michelini, Francesca (a cura di), Natura senza fine. Il naturalismo moderno e le sue forme. Bologna: EDB, 99-117.

Cahill, Kevin M.; Raleigh, Thomas (eds) (2018). Wittgenstein and Naturalism. London: Routledge.

Conway, Gertrude (1989). Wittgenstein on Foundations. Atlantic Highlands: Humanities Press International.

De Caro, Mario; Macarthur, David (eds) (2004). Naturalism in Question. Cambridge (MA): Harvard University Press.

Fogelin, R.J. (2009). Taking Wittgenstein at His Word. A Textual Study. Princeton; Oxford: Princeton University Press.

Glock, H.J. (2008). What is Analytic Philosophy? Cambridge: Cambridge University Press.

Laudisa, Federico (2014). Naturalismo. Filosofia, scienza, mitologia. Roma-Bari: Laterza.

McGinn, Colin (1984). Wittgenstein on Meaning. Oxford: Blackwell.

McGinn, Marie (2010), «Wittgenstein and Naturalism». De Caro, Mario; Macarthur, David (eds), Naturalism and Normativity. New York: Columbia University Press, 322-51.

Mounce, H.O. (2000). Introduzione al 'Tractatus' di Wittgenstein. Bari: Marietti.

Moyal-Sharrock, Danièle (2004). Understanding Wittgenstein's On Certainty. Basingstoke: Palgrave.

Moyal-Sharrock, Danièle (2013). «Wittgenstein's Razor: the Cutting Edge of Enactivism». American Philosophical Quarterly, 50 (3), 263-79.

Perissinotto, Luigi (2010). Wittgenstein. Una guida. Milano: Feltrinelli.

Putnam, Hilary [1992] (1998). Rinnovare la filosofia. Milano: Garzanti.

Quine, William Orman (1969), «Epistemology Naturalized». Quine, Quine, William Orman (1969), Ontological Relativity and Other Essays. New York: Columbia University Press, 69-90.

Strawson, P.F. (1985). Skepticism and Naturalism: some Varieties. The Woodbridge lectures 1983. New York: Columbia University Press.

Tripodi, Paolo (2009). Dimenticare Wittgenstein. Bologna: il Mulino.

Voltolini, Alberto (2009). Guida alla lettura delle "Ricerche Filosofiche" di Wittgenstein. Bari: Laterza.

Williams, Meredith (1999). Wittgenstein, Mind and Meaning. Toward a social conception of mind. New York: Routledge. 


\title{
Il naturalismo culturale di Dewey Il caso della mente
}

\section{Roberta Dreon}

Università Ca' Foscari Venezia, Italia

\begin{abstract}
The essay focuses on John Dewey's pragmatic naturalism in order to show that the relatively recent naturalizing trend in philosophy should be considered a historically and culturally situated restriction of other forms of naturalism. Dewey's cultural naturalism is based on a strong continuity between nature and culture, assuming that human intelligent behaviour arises from already existing organic and environmental resources in an entirely contingent manner. This kind of naturalism does not involve physical reductionism: more complex interactions between organisms and their environment, such as human mental behaviour, are seen as innovative, in the sense that they produce forms of organization that, on the one hand, are not reducible to the simple association of pre-existing elements. On the other hand, innovative modes of interaction between human organisms and their naturally social environment have consequence on the natural world: they produce changes within it. The second part of the text presents Dewey's non-substantive conception of the mind, which has its roots in the non-reversible consequences of the advent of highly communicative and linguistic interactions in the human world as well as in the possibility for human organism to reconsider analytically or reflectively their primarily holistic, qualitatively felt experiences.
\end{abstract}

Keywords Dewey. Naturalism. Mind. Continuism. Emergentism.

Sommario 1 Naturalismi. - 2 Che cos'è il naturalismo culturale di Dewey? 2.1 Naturalismo ed esperienza umana. - 2.2 II naturalismo culturale. - 2.3 Una prima sintesi. - 3 Mente, cognizione e psiche: un resoconto deflazionistico, naturalistico e funzionale. - 3.1 La mente non è una sostanza: dal nome al verbo. - 3.2 Per una storia naturale della mente. - 3.3 Aspetti di un resoconto funzionalista della mente. 4 Conclusioni. 


\section{$1 \quad$ Naturalismi}

Come è noto, a partire dal brillante saggio di Quine Epistemology Naturalized (Quine 1969), il cosiddetto naturalismo scientifico o scientista (De Caro, Macarthur 2004) ha avuto e continua ad avere una posizione preminente nella tradizione analitica in filosofia. Ciò nonostante, anche nel panorama filosofico contemporaneo sia il riduzionismo concepito come ideale regolativo (Dupré 2007, 11), sia l'assunto che i resoconti scientifici costituirebbero l'unica fonte non controversa per sviluppare un'ontologia esente da ogni appello al trascendentale, sono state problematizzate su vari fronti e forme alternative di naturalismo sono state messe in risalto. I naturalismi non riduzionisti di Hilary Putnam e di John McDowell, come quello più recente di John Dupré, mostrano che altre vie al naturalismo sono possibili anche nella filosofia contemporanea. D'altra parte, la critica dall'interno del cognitivismo portata avanti dai fautori dell'enattivismo, delle teorie della mente incorporata, radicata in un ambiente, nonché estesa oltre i confini dell'encefalo (Varela, Thomson, Rosch 1991; Gallagher 2017; Clark 2006), stanno mettendo a dura prova alcuni aspetti caratterizzanti del naturalismo scientifico, dal monismo fisicistico, al primato della causalità efficiente unidirezionale, alla nozione di sopravvenienza.

Questo tipo di lettura delle dinamiche filosofiche più recenti, però, offre un'immagine in parte distorta dei processi, perché tende a inquadrare le varie alternative alla naturalizzazione scientista come reazioni a un paradigma che sembra fondamentale - per cui ogni volta che si delinea una possibilità diversa, la sua prima caratterizzazione avviene per negazione: ci si sente in dovere di specificare che si tratta, appunto, di forme di naturalismo non riduzionista, come se il riduzionismo metodologico fosse un tratto essenziale del naturalismo tout court.

Tuttavia, se si adotta uno sguardo più ampio, staccandosi dalla contemporaneità più attuale anche di poco, il quadro che ne risulta è diverso e il ruolo del naturalismo scientista ne esce relativizzato. Secondo un approccio più ampio è piuttosto il riduzionismo naturalistico ad apparire come una restrizione, storicamente e culturalmente situata, di forme di naturalismo continuista già esistenti, più ricche e aperte.

È questo il caso del naturalismo pragmatista di John Dewey, sul quale si concentra questo saggio. Il naturalismo culturale di Dewey, erede di un Darwinismo non ideologico - antisostanzialista, antideterminista, nonché contingentista (Dewey 2007) -, insisteva su un continuismo di fondo tra natura e cultura. Il risultato è un approccio pluralista e tollerante sul piano ontologico - capace di ammettere non solo la causalità del biologico sul culturale, ma anche la retroazione del linguaggio condiviso e delle pratiche sociali e culturali sulle risorse naturali precedenti. Al contempo, il naturalismo di Dewey ci restituisce una concezione non sostantiva della mente, 
pur non rinunciando a evidenziare che l'avvento di interazioni significative e linguistiche sulle organizzazioni pregresse di forme di vita non umane con il loro ambiente di appartenenza porta con sé conseguenze irreversibili.

La prima parte di questo contributo sarà dedicata a chiarire quella forma di naturalismo, che Dewey nel libro del 1938 chiama appunto 'naturalismo culturale', ricostruendone i tratti a partire dai testi del pragmatista americano, ma anche accennando brevemente a un confronto con i termini del dibattito in filosofia della mente su 'sopravvenienza' ed 'emergenza'.

La seconda parte del saggio sarà invece dedicata a considerare alcuni aspetti portanti della concezione della mente elaborata da Dewey - un tema centrale perché, se da un lato costituisce un caso specifico di applicazione del naturalismo culturale, dall'altro, si tratta del caso per eccellenza del dibattito recente e antico intorno al dualismo mente-corpo, che tanta importanza ha avuto e continua ad avere sia tra i fautori che tra i detrattori della naturalizzazione.

\section{Che cos'è il naturalismo culturale di Dewey?}

\subsection{Naturalismo ed esperienza umana}

Nel 1927, Dewey pubblicava un saggio nel Journal of Philosophy, il cui titolo suonava Half-hearted Naturalism - qualcosa come, 'naturalismo incerto' o 'naturalismo fiacco' (Dewey 1984a). In questo modo si era espresso George Santayana nel 1925 (Santayana 1925) a proposito del naturalismo di Dewey, in una ampia recensione al suo libro Experience and Nature, che era stato appena pubblicato.

Dovendo rispondere alle critiche di Santayana, in questo articolo Dewey ha modo di chiarire che cosa intenda per naturalismo, anche se qui non parla ancora di 'naturalismo culturale', come farà nel suo ultimo lavoro di logica del 1938, Logic. The Theory of Inquiry. Qui parla piuttosto di 'empirical naturalism' o di 'naturalist empiricism', evidenziando il legame che connette il suo Esperienza e natura all'empirismo radicale di William James - profondamente continuistico a differenza della tradizione atomistica ed associazionistica dell'empirismo inglese (James 1976). Ma la dimensione culturale del suo naturalismo è già chiarissima.

La concezione della natura di Santayana, per cui questi accusa Dewey di essere un naturalista debole, è che essa sia priva di primi piani e di sfondi, di prospettive, di salienze, ovvero che essa sia essenzialmente indifferente a qualsiasi punto di vista umano (Santayana 1925, 678-9). Dewey ritiene che questa posizione sia indebita non perché non dimostrata o non dimostrabile - al contrario, essendosi appropriato della lezione di Peirce, Dewey ritiene che sia inevitabi- 
le che le nostre concezioni siano radicate su una base di credenze. Piuttosto il punto è che la credenza su cui si basa la concezione della natura di Santayana non è esplicitata: il filosofo ispano-americano parte dal presupposto assunto come ovvio che la natura sia estranea all'uomo, ovvero a tutto ciò che nell'uomo non è altro dal corpo fisicamente esteso: vale a dire, che la natura non possa che essere aliena alla cultura e alle istituzioni umane, all'esperienza umana, alla socialità e alle convenzioni che caratterizzano il mondo umano. Una concezione completamente deumanizzata della natura, come costituita da movimenti perpetui, piuttosto che da eventi e da storie è a sua volta il prodotto di una adesione dogmatica, di un belief indebito perché poco consapevole del proprio carattere di credenza.

Ma oltre a questa critica (1) che concerne l'ignoranza della dimensione opaca delle credenze su cui si ancorano i nostri argomenti (Peirce 1905), Dewey sostiene che Santayana assumerebbe l'idea dell'assenza di ogni punto di riferimento nella natura dalla fisica contemporanea (2), ovvero da una convenzione intellettuale molto tarda, di cui produrrebbe un'estensione indebita. ${ }^{1}$ Infine (3) - e questo è un punto cruciale per il naturalismo di Dewey -, supporre un'alterità totale della natura rispetto a ogni faccenda umana ha come conseguenza la ricaduta in una forma di credenza nel sovrannaturale o in qualcosa di analogo, perché questa posizione richiede che, se la comparsa dell'uomo e del mondo culturale è estranea e totalmente discontinua rispetto alla natura, è necessario un intervento dall'esterno o trascendente per spiegarla, come sottolinea efficacemente Joseph Margolis (2004).

Il belief da cui parte invece esplicitamente Dewey, al pari di Peirce e James, è che ci sia continuità tra l'uomo nella sua dimensione sociale e culturale e il mondo tout court, ovvero che la vita umana con i suoi tratti distintivi - l'esperienza, la cultura e la storia, la politica, l'arte e la tecnologia - siano 'tratti genuini' del mondo, si radichino in aspetti della natura precedenti all'avvento umano, ne siano 'proiezioni, continuazioni e complicazioni' che avvengo all'interno dello stesso mondo naturale. Pertanto l'esperienza umana, che per Dewey è interazione con un ambiente naturale e sociale e non dimensione intrapsichica, è nella natura, ne è un componente integrante.

Nell'ultima parte del saggio vi è anche una riferimento interessante alla mente, allorquando Dewey ricorda come Santayana, definendolo un comportamentista, lo accusa di negare la mente stessa. In vista della seconda parte di questo articolo è utile già anticipare che Dewey rifiuta come indebito questo passaggio: piuttosto, come

1 Non sono certa che Dewey colga nel segno con questa seconda critica. Più che la fisica contemporanea, sulla concezione della natura come intimamente estranea a ogni contributo umano mi sembra pesare l'influsso delle tesi di Schopenhauer e di Nietzsche, certo rielaborate in modo originale da Santayana. Su questo rinvio a Flamm 2002. 
del resto afferma in un saggio coevo, Body and Mind (Dewey 1984b), parlando di un comportamento intelligente o mentale e insieme emotivo, il suo intento è proprio quello di evitare l'ipostatizzazione di due sostanze ontologiche reciprocamente estranee, di opporre mente e materia, interno ed esterno.

In più, contro Santayana che lo accusava di 'misticismo etico o sociale' (Santayana 1925, 684), in continuità con quanto sostenuto in Experience and Nature, Dewey sostiene che la dimensione sociale e naturalmente culturale dell'esperienza umana è una parte integrante della natura che nasce quando le interazioni tra le forme di vita e i vari aspetti dell'ambiente naturale diventano forme di comunicazione, ovvero di fare in comune. Ignorare le conseguenze dell'esperienza umana - di cui Santayana riconosce a ragione il carattere non psicologico, ma immediatamente sociale e condiviso in Dewey significherebbe espungere in maniera indebita una parte integrante della natura e dover ricorrere a interventi extra-naturali per spiegare il contributo umano, la trama degli eventi e delle storie che nel naturalismo dogmatico del filosofo ispano-americano appariva come il livello meramente superficiale di una natura ben più profonda.

\subsection{Il naturalismo culturale}

Per ora, però, rinvio alla seconda parte di questo saggio l'approfondimento del ruolo della comunicazione nell'emergenza di una forma di esperienza specificamente umana, per considerare, invece, quali sono gli aspetti caratterizzanti del naturalismo culturale in base a quanto Dewey scrive in Logic. The Theory of Inquiry (Dewey 1991).

Sostenendo un approccio alla logica consapevole sia della matrice biologica che di quella culturale dell'indagine - vale a dire del conoscere umano nella sua dimensione in atto -, Dewey spiega che per naturalismo qui si intende l'assunzione che non vi sia soluzione di continuità tra le operazioni razionali e quelle fisico-biologiche, che le prime crescano (grow out of) a partire dalle seconde, ma che al contempo le operazioni razionali non possano essere considerate identiche o riducibili a quelle organiche da cui emergono (Dewey 1991, 25, 30). Da un lato, pertanto, è escluso che si debba fare ricorso all'intervento di elementi estranei o ulteriori rispetto alle risorse fisiche e organiche per l'avvento del mondo culturale, dell'attività significativa e razionale umana; dall'altra, tuttavia, è respinta anche la riduzione dei livelli più alti di interazione vitale con l'ambiente a quelli più bassi. Il naturalismo culturale non implica forme di fisicismo riduzionistico perché le interazioni più complesse tra gli organismi e il loro ambiente sono intese come innovative - sebbene nascano da risorse organiche e ambientali già preesistenti in maniera del tutto contingente -, nel senso che producono forme di organizzazione che non so- 
no riducibili alla semplice associazione degli elementi preesistenti, e anzi sono tali da retroagire, da produrre a loro volta dei cambiamenti sul mondo organico precedente.

Il problema cruciale di cui una posizione continuista deve farsi carico - Dewey non se lo nasconde - è quello di spiegare le «differenze straordinarie che demarcano le attività e le conquiste degli esseri umani rispetto a quelle di altre forme biologiche» (Dewey 1991, 49; trad. dell'Autore). Il punto, in altre parole, è comprendere come sia avvenuta la trasformazione di attività meramente organiche in comportamenti intelligenti, dotati di significato, evitando il ricorso a interventi esterni come accadrebbe invece in una prospettiva radicalmente discontinuistica e dualistica tra natura e cultura, mondo e razionalità. A parere di Dewey l'insorgenza del linguaggio a partire da una combinazione del tutto contingente di risorse organiche e da un ambiente sociale preesistenti è la chiave per comprendere questa trasformazione (cf. Margolis 2017 e Tomasello 2008), dove però il linguaggio è inteso nel senso ampio che include tutti i sistemi di comunicazione umana, gestuale, iconica, verbale. Dewey $(1991,51)$ nota che oltre a essere una istituzione culturale tra le altre, il linguaggio e più in generale la comunicazione umana sono i modi attraverso i quali sono acquisiti e trasmessi gli abiti, i quali permeano tutte le altre attività culturali, e per loro tramite si realizzano forme di astrazione e di estensione dei significati a contesti via via più ampi di pratiche. Centrale è inoltre il ruolo del linguaggio nella trasformazione della socialità animale in quella specificamente umana. È chiaro che per Dewey, che cita Aristotele, la dimensione sociale della forma di vita umana è indiscutibile, non può essere revocata da un dubbio genuino, se solo si considera la strutturale dipendenza dell'essere umano, alla nascita, dal gruppo sociale di appartenenza (cf. Dewey 1988a, Mead 2001, 73). Inoltre, al pari di Mead e ben prima di Tomasello (1999), Dewey aveva ben chiaro che molte forme di vita animale sono fortemente socializzate e che la questione vera è quella di mettere a fuoco la peculiarità della socialità umana, che consiste a suo parere nella possibilità di una 'comunità di azione', di una 'impresa comune' sulla base della condivisione di significati e di un'eredità culturale oltre che fisica (Dewey 1991, 49). Da questo punto di vista, «il linguaggio non originò l'associazione, ma quando sopravvenne (supervened) quale emergenza (emergence) naturale a partire da forme precedenti di attività animale, reagì in modo da trasformare i modi precedenti di comportamento associato in maniera tale da conferire una nuova dimensione all'esperienza» (Dewey 1991, 63), una dimensione culturale e intelligente. ${ }^{2}$

2 Per una posizione analoga si veda Dupré (2007, 39): «l'esistenza di simboli significativi richiede l'esistenza di una comunità. Un cervello, o una mente, possono contenere rappresentazioni simboliche solo in virtù del rapporto tra il loro possessore e una comunità di persone che usano quei simboli». 
Da un lato, il libro del 1938 dedicato alla logica, non poteva non insistere sulla straordinaria potenza astrattiva del linguaggio, che appare fondamentale nel realizzare via via il passaggio da forme di significazione, basate su segni naturali, a simboli e a parole che possono essere condivise da un'intera comunità di parlanti.

Dall'altro lato, Dewey si esprime nettamente a favore di una retroazione della dimensione culturale dell'esperienza umana sull'ambiente naturale. La socialità umana si distingue dal modo in cui sono sociali le api e le formiche perché l'ambiente umano è trasmesso culturalmente, ovvero non è semplicemente naturale, ma ha incorporato una eredità culturale fatta di abiti, istituzioni, tradizioni e credenze che hanno prodotto e producono una riconfigurazione importante dell'ambiente naturale. Dewey arriva a dire che perfino «le strutture neuro-muscolari degli individui sono modificate dall'influenza dell'ambiente culturale sulle attività che esse compiono» (Dewey 1991, 49), tanto che l'interpenetrazione degli aspetti culturali del comportamento umano con le componenti fisiologiche è tale da rendere difficile e comunque successiva, non primaria, la loro distinzione - dal procurarsi il cibo all'alimentarsi, al modo in cui camminiamo e ci orientiamo nello spazio (cf. Mauss 1934), alla sessualità umana.

\subsection{Una prima sintesi}

Volendo fare un bilancio molto sintetico del naturalismo culturale sulla base dei termini più recenti del dibattito su dualismo, 'riduzionismo materialistico', 'sopravvenienza' o 'emergenza' (Davidson 1980 e Kim 1993), la posizione di Dewey sarebbe senz'altro riconducibile a una forma di emergentismo - sebbene, scrivendo in anni precedenti l'avvento delle distinzioni tecniche tra 'sopravvenienza' ed 'emergenza', il pragmatista faccia ricorso sia alle parole 'emergence' ed 'emerge', sia al verbo 'supervene', favorendo tuttavia sempre il termine 'continuity' nel senso indicato sopra. Limitarsi a registrare una covarianza tra i fenomeni mentali e quelli neurali e, più in generale tra quelli culturali e quelli organici nel mondo umano - come accade nel monismo anomalo - non sarebbe senz'altro stata una mossa conforme alle sue corde, filosofiche e umane. Soprattutto, il postulato della 'struttura causale del fisico' (Kim 1993) non avrebbe potuto che apparire come non giustificato a Dewey, basato in ultima analisi sulla credenza indebita che solo ciò che è fisico è reale e che solo ciò che è fisico può produrre una azione causale. Tuttavia, i tratti del naturalismo culturale di Dewey o, se vogliamo, del suo emergentismo sono tutt'altro che incoerenti. In estrema sintesi, potremmo riassumerli in questo modo: 
1. Le pratiche culturali e le attività intelligenti tipicamente umane crescono a partire sia da risorse preesistenti organiche e fisiologiche sia dall'ambiente naturale.

2. Ė escluso il ricorso a forme di intervento esterno o ulteriore rispetto alle interazioni organico-ambientali per l'insorgenza del mondo culturale - un nous di origine divina, una ragione a priori.

3. L'insorgenza del linguaggio, dell'attività intelligente, delle pratiche culturali da forme di organizzazione delle dinamiche organico-ambientali preesistenti e meno complesse è del tutto contingente e casuale, non determinata da un processo evolutivo inteso come sviluppo teleologico da forme di vita considerate 'inferiori' a forme di vita 'superiori'. ${ }^{3}$

4. Le forme più complesse di organizzazione delle risorse precedenti in cui consistono le attività intelligenti umane sono nuove, nel senso che fanno comparire aspetti ed eventi altri e inaspettati rispetto al panorama precedente e irriducibili alla mera somma degli elementi preesistenti: si tratta di modi di interazione delle forme di vita umana con l'ambiente naturale e naturalmente sociale che sono (a) irreversibili e (b) tali da comportare una trasformazione dell'ambiente naturale, una cospicua riconfigurazione anche di attività puramente fisiologiche preesistenti.

5. La trasformazione di attività semplicemente organiche in comportamenti significativi, intelligenti, in tradizioni e istituzioni sociali e culturali è legata all'insorgenza nella forma di vita umana del linguaggio e di modi di comunicazione che rendono possibile la condivisione di attività e di scopi, ovvero una forma di socialità molto pronunciata.

\section{Mente, cognizione e psiche: un resoconto deflazionistico, naturalistico e funzionale}

Si tratta ora di comprendere quale concezione della mente venga elaborata da Dewey, distinguendola dai modi di interazione con l'ambiente che il filosofo caratterizza come psico-fisici, ovvero come propri di forme di vita già complesse, ma non umane. In estrema sintesi, potremmo sostenere che il resoconto che Dewey ne fornisce a più livelli è deflazionista e antisostanzialista (I), genetico ed emergentista (II) e funzionalista (III). In tutti i casi, i toni sono sempre critici verso il dualismo tra mente e corpo, nonché verso ogni forma di riduzionismo - che di solito viene designato come 'materialismo' dal pragma-

3 Su questo cf. la lettura peculiare che Dewey fa di Darwin e il peso delle teorie evoluzionistiche di Chauncey Wright sul Metaphysical Club. 
tista americano. La sua interpretazione della mente è pertanto del tutto coerente con il naturalismo culturale propugnato da Dewey, che parla in modo esplicito della sua proposta come di «an 'emergent' theory of mind» (Dewey 1988b, 207), dove l'aggettivo 'emergent' è posto tra virgolette. ${ }^{4}$

\subsection{La mente non è una sostanza: dal nome al verbo}

Potremmo sostenere che il primo aspetto qualificante dell'interpretazione di Dewey è che l'adozione del termine sostantivo 'mente' è filosoficamente fuorviante. In poche pagine interessanti di un capitolo di Art as Experience sui fraintendimenti creati nella teoria estetica da una serie di concetti psicologici fallaci, Dewey invita il lettore a considerare gli usi idiomatici di 'mind', che hanno un carattere prevalentemente verbale o avverbiale nell'Inglese ordinario, piuttosto che un uso sostantivo (Dewey 1989, 267-8). 'Being reminded of something' significa che ci viene ricordato qualcosa, 'Bringing mind on something' vuol dire fare attenzione a qualcosa: in ogni caso, nota Dewey, l'assunto implicito non è che la mente sia un'entità separata o indipendente dalla realtà, ma che sia sempre esposta a fatti, eventi, oggetti del mondo. Inoltre, una serie variegata di usi del verbo 'to mind' come prendersi cura, fare attenzione ai passi che si stanno compiendo, perfino obbedire a qualcuno, mostra come nel linguaggio ordinario il mentale non sia esclusivamente correlato a contesti di tipo cognitivo, ma riguardi anche la sfera degli affetti e dell'azione pratica. Indulgere invece nella sostantivizzazione del verbo tende a produrre una ipostatizzazione della mente in un'entità indipendente dall'ambiente con cui agisce, che sarebbe presupposta ai diversi modi di azione. Dewey pensa che 'mentale' sia piuttosto il carattere, la modalità o la qualità di un certo tipo di interazioni tra la forma di vita specificamente umana e l'ambiente cui essa appartiene e da cui dipende. ${ }^{5}$ Da questo punto di vista Dewey rifiuta sia la tradizione cartesiana della mente come sostanza esistenziale peculiare, essenzialmente diversa dalla sostanza estesa fisica, sia la concezione di derivazione empiristico inglese, humiana, per cui la mente consisterebbe nel risultato dell'associazione o nella sommatoria di percezioni diverse tra di loro, nonché dalle loro relazioni reciproche. ${ }^{6}$

4 Alcuni aspetti di questa analisi sono stati già sviluppati in Dreon 2019b.

5 Su questo cf. Steiner 2017.

6 Su questo punto si veda The Logical Character of Ideas del 1908, ripubblicato negli Essays in Experimental Logic nel 1916 (Dewey 2004). 


\subsection{Per una storia naturale della mente}

Per formulare una concezione alternativa della mente Dewey parte dall'ovvietà biologica' per cui ogni essere vivente, ogni forma di vita interagisce con un ambiente di appartenenza secondo modalità e gradi diversi (Dewey 1989, 20) - non può non farlo, il vivere consiste in questo, non c'è un'autosufficienza del soggetto che poi, a partire dalla propria autonoma determinazione, si porrebbe il problema del rapporto con gli oggetti e con gli altri soggetti. In Experience and Nature (Dewey 1988b), che utilizzerò come riferimento principale, Dewey nota che, rispetto agli esseri inanimati, gli esseri viventi si caratterizzano perché le loro relazioni con l'ambiente cui ineriscono sono sempre di parte (biased, si dice in Dewey 1979) o interessate, nel senso che sono sempre orientati a mantenersi in vita, non sono indifferenti ai risultati che ha l'azione dell'ambiente su di essi, nonché alle conseguenze che le loro stesse attività hanno sulla loro vita - ovviamente secondo gradi più complessi e raffinati a seconda delle diverse forme di vita, in cui una discontinuità importante è rappresentata dalla capacità dell'(auto)movimento, della locomozione, che rende possibile le forme del differimento della soddisfazione, aprendo il rinvio ad altro non immediatamente presente nelle vicinanze dell'organismo in questione. Per questo diciamo che gli esseri viventi hanno un destino, sono soggetti al fato o al caso, ovvero hanno una storia. L'essere di parte pertanto non riguarda solo gli uomini, ma almeno gli animali capaci di locomozione, i quali sviluppano un tipo di sensibilità che implica una strutturazione anche temporale dell'interazione: invece di compiersi immediatamente, si articola in un momento preparatorio che è una anticipazione, e in una fase di compimento (fulfilment) in cui l'azione è portata a termine (consummation). Questo tipo di organizzazione delle interazioni che è tipica delle forme animali più complesse, ma non è capace di riflessione - non è mentale secondo Dewey, ma è chiaro che implica forme di intelligenza diverse - insiste su attività e comportamenti che il filosofo americano chiama 'psico-fisici', perché le strutture biologiche stesse sono orientate a una sensibilità selettiva fine, in cui le cose sono discriminate, ovvero sentite come favorevoli o avverse, buone o cattive, pur non essendo propriamente conosciute. I feeling diventano poi sensi e significati nelle interazioni tipicamente umane - senza che questo percorso sia assimilabile a uno sviluppo teleologico dall'inferiore al superiore, che è del tutto estraneo alla lettura darwiniana di Dewey (2007; su questo cf. Cometti 2015) e all'enfasi sul caso caratteristica di tutti i pragmatisti classici (cf. Calcaterra 2011).

Ebbene, quando e come emergerebbero forme di organizzazione mentale delle interazioni organico-ambientali? 
Stando al livello filogenetico dell'interpretazione dei fenomeni mentali, ${ }^{7}$ la mente non è identificabile con un istinto innato, né può essere considerata come equivalente a certi sostrati o processi neurologici - di cui Dewey non nega l'importanza, ma che considera come uno degli aspetti in gioco nello sviluppo del mentale. La mente deve essere compresa come una qualità delle interazioni umane con l'ambiente che è stata acquisita nel corso del processo evolutivo. Tale processo si sarebbe generato a partire da condizioni precedenti già date - già animali anche se non umane - che sono state modificate sotto la pressione di un ambiente caratterizzato da una forte dipendenza del singolo dal gruppo sociale di appartenenza, ovvero dalla necessità forzata alla condivisione di attività, comportamenti, credenze. Addirittura, Dewey arriva a sostenere che la mente sia il by-product, il prodotto collaterale di una forma di vita strutturalmente associata e congiunta - ovvero caratterizzata da forme di interdipendenza strutturale. Essa consisterebbe in una serie di disposizioni, credenze, atteggiamenti, comportamenti innanzitutto sociali, condivisi e che su questa base emergerebbero anche le identità individuali (cf. Dewey 1979, § 2).

'Mentale' per Dewey è una modalità di interazione con l'ambiente di tipo riflessivo, capace cioè di tornare analiticamente sulle situazioni indeterminate, discriminando le parti salienti nel continuum esperienziale, per cercare di capire il da farsi - il che comporta (Dewey 1988b, 211) un riuso di strutture biologiche precedenti per nuovi scopi. In altri termini, il mentale implica lo sviluppo cognitivo dell'esperienza umana, ovvero una svolta riflessiva che estende la condotta umana a una ricca gamma di possibilità alternative di condotta e produce una riconfigurazione culturale dell'ambiente naturale.

Questo significa che la mente è continua con la natura, che non interviene nella natura come un elemento esterno, trascendente la natura stessa; d'altra parte, però non è riducibile alle altre fasi o modalità della vita organica. La mente è invece una fase interna alla natura e comunque non riducibile a qualcosa d'altro che la precede, perché se ne distingue e sporge rispetto a essa per la nuova organizzazione delle interazioni organico-ambientali in cui consiste - un'organizzazione non solo più complessa, ma anche qualitativamente innovativa, irriducibile alla somma degli aspetti fisici e biologici su cui si radica.

7 Si veda The Need of Social Psychology del 1917, dal quale si evince una strettissima collaborazione con Mead (Dewey 1980). 


\subsection{Aspetti di un resoconto funzionalista della mente}

Volendo ora cercare di mettere a fuoco il piano funzionale, Dewey sostiene che le modalità delle interazioni con il mondo diverrebbero 'mentali' (e non solo 'psico-fisiche', come vedremo in seguito) nel caso delle forme di vita umana, perché nell'uomo si avviano processi di riconsiderazione riflessiva o analitica su quanto subisce dall'ambiente e sui modi in cui a sua volta gli organismi umani agiscono o possono agire sull'ambiente, contribuendo a modificarlo. Da questo punto di vista appare evidente che per Dewey le relazioni mentali degli umani con l'ambiente (ma nemmeno quelle delle altre forme animali) non sono orientate a un rispecchiamento fedele, quanto a un'azione dall'interno e a una capacità di riconsiderare criticamente l'azione stessa (questo è il tratto umano peculiare) quando non funziona, quando il da farsi è incerto e richiede una revisione analitica degli elementi di un'esperienza altrimenti integrale.

Qui si apre lo spazio dell'indagine e delle inferenze, ovvero per Dewey della cognizione intesa come processo in atto (e non come sostanza o facoltà attribuibile $\mathrm{a}$ un soggetto). Le interazioni umane con l'ambiente sono mentali perché gli uomini sono capaci di mutare delle mere suggestioni, per le quali qualcosa di presente suggerisce qualcosa di assente di cui è segno (il fumo suggerisce il fuoco e ne è segno), in significati (meanings). Di passaggio, può essere interessante notare che Dewey parla di 'suggestions' invece che di indicazioni nella Introduction del 1916 agli Essays in Experimental Logic (Dewey 2004): invece di concentrarsi sul riferimento oggettuale, Dewey sembra accennare all'idea che certe cose sono avvertite come dei suggerimenti, degli inviti ad agire in certo modo. ${ }^{8}$ Ritornando sul passaggio dal segno al significato - da una relazione diadica a una relazione triadica -, non è che il fumo da evento esterno diventi mentale perché una sua presunta immagine non fisica ma psichica si produrrebbe nella mente intesa come luogo interiore; non c'è alcun bisogno di pensare che il fumo si duplichi in una rappresentazione interna che corrisponda al fenomeno esterno. La parola 'fumo' nella concretezza degli scambi comunicativi in cui compare è parte di un comportamento mentale in quanto, alle prese con un ostacolo, con un contesto incerto, il fumo - segno che suggerisce il fuoco - entra in un processo d'indagine, cognitivo o riflessivo, in cui viene distinto analiticamente e fissato in gesti e in parole che orientano l'azione degli interlocutori.

Inoltre, è chiaro che per Dewey l'emergenza di forme di interazione mentale tra gli esseri umani e il loro ambiente di appartenenza si ba-

8 Da questo punto di vista, non sembra lontano il passo dalle 'suggestions' alle 'affordances' della psicologia ecologica di Gibson e dell'enattivismo, intese come inviti ad agire in un certo modo. 
sa sul linguaggio inteso come scambio significativo tra parlanti: non va considerato solo che le parole siano agenti di fissazione delle 'suggestions' segniche molto più stabili dei gesti, ma anche che l'ambiente naturale di appartenenza umano sia sociale, perché il destino o la storia di ognuno di noi dipende non solo dalle nostre azioni individuali, ma soprattutto dalle attività condivise, dalla partecipazione (pacifica o conflittuale) a forme di vita associata. Il linguaggio verbale (Dewey $1988 b, 213)$ non è un veicolo di trasmissione di rappresentazioni interne, ma in primo luogo un mezzo per regolare reciprocamente la condotta degli interlocutori in vista dell'azione: il linguaggio stesso è un tipo di comunicazione di gesti vocali, che sebbene estenda e trasformi le forme di comunicazione gestuale precedente, resta in nuce una forma di gesto, ovvero di azione che è portatrice di un significato condiviso a chi parla e a chi ascolta in vista di un'azione comune (Dreon 2014, 2019a). Le parole consentono non solo di ritenere le conseguenze delle mie azioni precedenti e di anticipare i risultati delle mie azioni future, ma soprattutto di conservare e prevedere gli effetti dei comportamenti altrui: è del mondo degli altri, dei miei simili che il linguaggio è portatore, piuttosto che di una attività di pensiero che avrebbe luogo innanzi tutto nel chiuso della mia mente o di una computazione neurale di un cervello isolato dal resto del corpo e del mondo.

\section{Conclusioni}

Per concludere con una nota formula di Margolis, per caratterizzare la posizione pragmatista (Margolis 2002), si potrebbero riassumere sinteticamente gli aspetti fin qui considerati, sostenendo che Dewey propone una concezione della mente come fenomeno naturale, ma non naturalizzabile.

La mente non è un tipo di sostanza distinta ontologicamente dalla sostanza fisica, né una condizione interna separata e autonoma rispetto a ciò che accade nella realtà esterna. Per darne una caratterizzazione in positivo, può essere utile rifarsi ai punti con cui abbiamo caratterizzato in precedenza il naturalismo culturale di Dewey:

1. Mentale è la qualità intelligente o significativa delle interazioni tra gli organismi umani e l'ambiente - mentale è una nuova forma di organizzazione delle transizioni organico-ambientali -, che cresce a partire da forme precedenti di organizzazione degli scambi tra organismi viventi e il loro ambiente.

2. È escluso il ricorso a forme di intervento esterno o ulteriore rispetto alle interazioni organico-ambientali precedenti per spiegare la configurazione in termini mentali delle interazioni umane con il mondo.

3. La qualità mentale, significativa, delle interazioni umane - lo spirito o il pensiero - insorge da forme di organizzazione delle 
dinamiche organico-ambientali preesistenti e meno complesse in modo del tutto contingente e casuale, non determinata da un processo evolutivo inteso come sviluppo teleologico da forme di vita considerate 'inferiori' a forme di vita 'superiori'.

4. La qualità mentale, intelligente o significativa dei comportamenti umani fa comparire aspetti, tratti, eventi altri e inaspettati rispetto alla sensibilità animale precedente e irriducibili alla mera somma degli elementi preesistenti: non solo è irreversibile ma è anche tale da retroagire sulla sensibilità precedente, che contribuisce a riconfigurare.

5. La trasformazione di attività semplicemente organiche in comportamenti mentali, significativi, intelligenti, in tradizioni e istituzioni sociali e culturali è legata all'insorgenza nella forma di vita umana del linguaggio e di modi di comunicazione che rendono possibile uno spazio comune, la condivisione di attività, di scopi e di significati.

\section{Bibliografia}

Calcaterra, Rosa Maria (2011). "Varieties of Synechism. Peirce and James on Mind-World Continuity». Journal of Speculative Philosophy, 25(4), 412-24.

Clark, Andy (2006). «Language, Embodiment, and the Cognitive Niche». Trends in Cognitive Neurosciences, 10(8), 370-4.

Cometti, Jean-Pierre (2015). «Making the Difference: John Dewey and the Naturalization of Aesthetics». Aisthesis, 8(1), 123-34.

Davidson, Donald (1980). «Mental Events». Davidson, Donald, Essays on Actions and Events. Oxford: Clarendon Press, 207-25.

De Caro, Mario; Macarthur, David (2004). «The Nature of Naturalism». De Caro, Mario; Macarthur, David (eds), Naturalism in Question. Cambridge (MA): Cambridge University Press.

Dewey, John (1979). «What are States of Mind?». Middle Works, vol. 7. Carbondale; Edwardsville: Southern Illinois University Press, 31-43.

Dewey, John (1980). «The Need for Social Psychology». Middle Works, vol. 10. Carbondale; Edwardsville: Southern Illinois University Press, 53-63.

Dewey, John (1984a). «Half-Harted Naturalism». Later Works, vol. 3. Carbondale; Edwardsville: Southern Illinois University Press, 73-81.

Dewey, John (1984b). «Body and Mind». Later Works, vol. 3. Carbondale; Edwardsville: Southern Illinois University Press, 25-40.

Dewey, John (1988a). Human Nature and Conduct. Vol. 14 of Middle Works. Carbondale; Edwardsville: Southern Illinois University Press.

Dewey, John (1988b). Experience and Nature. Vol. 1 of Later Works. Carbondale; Edwardsville: Southern Illinois University Press.

Dewey, John (1989). Art as Experience. Vol. 10 of Later Works. Carbondale; Edwardsville: Southern Illinois University Press.

Dewey, John (1991). Logic. The Theory of Inquiry. Vol. 12 of Later Works. Carbondale; Edwardsville: Southern Illinois University Press.

Dewey, John (2004). Essays in Experimental Logic. Mineola; New York: Dover Publication. 
Dewey, John (2007). «The Influence of Darwin on Philosophy». Hickman, Larry A. (ed.), The Influence of Darwin on Philosophy and Other Essays in Contemporary Thought. Carbondale; Edwardsville: Southern Illinois University Press, 5-12.

Dreon, Roberta (2014). «Dewey on Language: Elements for a Non-Dualistic Approach». European Journal of Pragmatism and American Philosophy, VI(2), 109-24.

Dreon, Roberta (2019a). "Gesti emotivi e gesti verbali. L'eredità di George Herbert Mead sulla genesi del linguaggio umano». Sistemi Intelligenti, XXXI(1), 115-33.

Dreon, Roberta (2019b). «Framing Cognition. Dewey’s Potential Contributions to some Enactivist Issues», in "Radical Views of Cognition», spec. issue, Synthese, 1-22. DOI https://doi.org/10.1007/s11229-019-02212-x.

Dupré, John (2007). Natura umana. Perché la scienza non basta. Roma-Bari: Laterza.

Flamm, Matthew Caleb (2002). «Santayana and Schopenhauer». Transactions of the Charles S. Peirce Society, 38(3), 413-31.

Gallagher, Shaun (2017). Enactivist Interventions. Rethinking the Mind. Oxford: Oxford University Press.

Kim, Jaegwon (1993). «Concepts of Supervenience». Supervenience and Mind. Cambridge: Cambridge University Press, 53-78.

James, William (1976). Essays in Radical Empiricism. Cambridge (MA): Harvard University Press.

James, William (1981). The Principles of Psychology. Cambridge (MA): Harvard University Press.

Margolis, Joseph (2002). Reinventing Pragmatism. American Philosophy at the End of the Twentieth Century. Ithaca; London: Cornell University Press.

Margolis, Joseph (2004). «Placing Arworks - Placing Ourselves». Journal of Chinese Philosophy, 1(31), 1-16.

Margolis, Joseph (2017). Three Paradoxes of Pernsonhood. The Venetian Lectures. Ed. by Roberta Dreon. Milano: Mimesis International.

Mauss, Marcel (1934). «Les techniques du corps». Journal de Psychologie, XXXII, 3-4.

Mead, George Herbert (2001). Essays in Social Psycology. Ed. by M.J. Deegan. New Brunswick; London: Transaction Publishers.

Peirce Charles Sanders (1905). «Issues of Pragmaticism». The Monist, 15, 481-99.

Quine, William Orman (1969). «Epistemology Naturalized». Quine, William Orman, Ontological Relativity and Other Essays. New York: Columbia University Press, 69-90.

Santayana, George (1925). «Dewey's Naturalistic Metaphysics». The Journal of Philosophy, 22(25), 673-88.

Steiner, Pierre (2008). «Délocaliser les phénomènes mentaux: la philosophie de l'esprit de Dewey». Revue Internationale de Philosophie, 62 (245), 3(2008), 273-92.

Steiner, Pierre (2017). «Pragmatism in Cognitive Science: from the Pragmatic Turn to Deweyan Adverbialism». Pragmatism Today, 8(1), 9-27.

Tomasello, Michael (1999). The Cultural Origins of Human Cognition. Cambridge (MA): Harvard University Press.

Tomasello, Michael (2008). Origins of Human Communication. Cambridge (MA): MIT Press.

Varela, Francisco; Thompson, Evan; Rosch, Eleanor (1991). The Embodied Mind: Cognitive Science and Human Experience. Cambridge (MA): MIT Press 



\title{
Il linguaggio come collante tra menti individuali e socialità umana
}

\section{Filippo Batisti}

Università Ca' Foscari Venezia, Italia

\begin{abstract}
The pragmatist tradition in philosophy has left a sound legacy in many contemporary research fields. John Dewey's continuist and emergentist approach to the nature-or-nurture problem in relation to the individual human mind has been regained lately in evolutionist psychology and related disciplines. For Dewey, language plays a fundamental role in creating and maintaining this continuity between the individual mind and the social and physical environment humans inhabit. The present article will focus on a few contemporary lines of research that identify language as the 'glue' that bonds each individual to one another and to society, with a decisive impact on the development of one's own mind.
\end{abstract}

Keywords Culture and mind. Human sociality. Language and cognition. Nature vs. nurture. Nick Enfield.

Sommario 1 Introduzione. - 2 La continuità tra individuo e ambiente. - 3 La socialità umana tra linguaggio e mente. - 4 Paradigmi di ricerca.

\section{Philosophica 4}




\title{
1 Introduzione
}

\author{
Il linguaggio è inseparabile dall'uomo, e lo accompa- \\ gna in ogni sua attività. Il linguaggio è lo strumento \\ con cui l'uomo forma pensieri e sentimenti, stati d'a- \\ nimo, aspirazioni, volizioni ed azioni, lo strumento \\ con cui influenza ed è influenzato, il fondamento ul- \\ timo e più profondo della società umana. \\ (Louis Hjelmslev. I fondamenti della teoria \\ del linguaggio, 1968)
}

\begin{abstract}
All'interno della tradizione pragmatista, Dewey (1991) si distingue per l'approccio continuista alla presunta dicotomia tra natura e cultura per quanto riguarda il rapporto tra lo sviluppo della mente individuale degli esseri umani e l'ambiente fisico e sociale che essi abitano. Alcune tendenze di ricerca contemporanee hanno recuperato queste suggestioni deweyane (Steiner 2017). A partire da queste ultime, farò una breve ricognizione degli studi degli ultimi due decenni su mente, linguaggio e socialità.
\end{abstract}

\section{La continuità tra individuo e ambiente}

In questa recente letteratura si può isolare una tendenza generale: quella di privilegiare quella che Dewey chiama «continuità». Questa nozione è a sua volta tripartita nella continuità (1) tra la mente individuale e le altre menti; (2) tra la 'privatezza' della mente individuale e il rapporto con l'ambiente esterno (Vygotsky 1978); da ultimo, (3) il riconoscimento dello stretto rapporto tra cultura, ecologia, linguaggio e cognizione.

La direzione indicata da Dewey è stata ripresa in considerazione molti decenni più tardi e consiste nel cessare di considerare l'individuo in isolamento, nell'ambito dello studio multidisciplinare della formazione e dello sviluppo dell'essere umano e delle facoltà che lo caratterizzano. La discontinuità corporale che ci separa gli uni dagli altri non è evidentemente sufficiente per ignorare il fatto che l'apprendimento e l'uso linguistico sono attività umane per definizione sociali e intersoggettive: sarebbe una miope astrazione quella di considerarci - al livello dell'analisi filosofica e scientifica - alla stregua di nuclei conoscenti-parlanti atomizzati. Lungo direttrici diverse ma intersecantisi, sia la grammatica generativa di ispirazione chomskiana, sia il paradigma cognitivista classico in psicologia hanno teso invece ad avere un approccio cerebro-centrico che, nell'identificare il cervello come perno dell'attività conoscitiva umana, ha trascurato l'importanza della situatedness della cognizione, che è fisica tanto quanto sociale e culturale (Arponen 2013; Björk 2008; Gardner 
1985; Pennisi, Falzone 2015). In sintesi, «il paradigma chomskyano rimane sostanzialmente disincarnato, senza corpo» (Pennisi, Falzone 2015, 163), coerentemente con la metafora che ha ispirato molta della scienza cognitiva classica: la mente è una macchina (Boden 2006). Quanto all'atomizzazione, Dewey mantiene una posizione opposta: il concetto di 'individuo' - lo stesso che nelle scienze cognitive e sociali solitamente vale come unità di misura di base - è per lui un concetto che 'emerge' dall'inserimento e dalla partecipazione del soggetto in un ambiente che non può che essere sociale. Da questo stesso ambiente l'individuo è in prima battuta plasmato, per poi successivamente contribuire a plasmarlo a sua volta, nel momento in cui interagendovi diventa parte di un tale sistema complesso.

\section{La socialità umana tra linguaggio e mente}

Dopo aver delineato questa cartografia minima dei temi che voglio toccare tra Dewey e il contemporaneo, per approfondirli raccoglierò alcuni spunti offerti dai variegati studi di Nick Enfield, etnolinguista per lungo tempo associato al Centro per la psicolinguistica Max Planck di Nimega, dove ha indagato il rapporto tra linguaggio e socialità umana. Enfield (2010) incomincia dalla constatazione che la mente umana è una mente sociale. Tuttavia,

gran parte della ricerca sul linguaggio e sulla mente si è concentrata sull'individuo preso in isolamento, riservando poca attenzione alla performance o alla competenza nell'ambiente sociale. (Enfield 2010, 5; trad. dell'Autore)

Per lungo tempo i linguisti, da un lato, non si sono interessati dell'applicazione concreta e dei contesti culturali d'uso delle forme linguistiche così come, dall'altro, gli antropologi non hanno quasi mai pensato di doversi occupare anche di linguistica. D’altro canto, Gary Lupyan (2015) ha fatto notare che storicamente la psicologia cognitiva ha trascurato lo studio del linguaggio, privilegiando la sua funzione comunicativa e trascurando quella cognitiva, cioè il fatto che contribuisca alla formazione ex novo di (alcuni) concetti ${ }^{1}$ (Asoulin 2016, Dove 2018). Questo è stato dovuto, nell'ultimo mezzo secolo, al successo delle tesi di stampo fodoriano-chomskiano circa il fatto che il linguaggio non faccia altro che mappare concetti preesistenti, invece che (contribuire a) formarli (Lupyan 2015). Analogamente,

1 In linguistica teorica è invece riscontrabile maggiore attenzione alla funzione formativa della lingua: si veda il caso della linguistica strutturalista (Hjelmslev) e i suoi antecedenti (Humboldt, Saussure). Si veda Diodato 2019. 
in senso opposto, soltanto nell'ultimo decennio ricerche empiriche appartenenti al filone della embodied cognition hanno sottolineato che per quanto riguarda il caso dell'acquisizione delle parole astratte il linguaggio «funziona come uno strumento sociale», in quanto

[le parole] estendono le possibilità del nostro pensare e ci spingono alla socialità quando dubitiamo della nostra conoscenza e abbiamo bisogno di condividerla e allinearci con gli altri. (Borghi et al. 2018, 6; trad. dell'Autore)

Analogamente, la linguistica stessa ha dedicato una mole di lavoro ben più corposa all'analisi del versante 'intra-linguistico' - che tratta le relazioni tra gli elementi della grammatica - rispetto allo studio dei rapporti tra linguaggio e gli altri campi dell'esperienza umana. In altre parole, a livello quantomeno quantitativo, la linguistica teorica e lo studio della grammatica hanno avuto il sopravvento sugli oggetti di studio di altre sotto-discipline come sociolinguistica, psicolinguistica o etnolinguistica, ora non più ancillari o 'ibride'. Appare quindi fondamentale tendere verso una integrazione di questi approcci, per comprende meglio il funzionamento di porzioni critiche di facoltà specificamente umane come quella linguistica.

Quanto riportato finora non è affatto dissimile dalle ragioni che stimolavano Dewey a rifiutare separazioni nette di stampo riduzionista tra mera biologia e gli altri campi dell'esperienza umana. Ad esempio, per quanto riguarda la differenziazione tra animali ed esseri umani, Dewey sottolineava una differenza non ontologica, bensì di modalità di organizzazione delle interazioni dei soggetti con l'ambiente: infatti da una sensibilità comune tra animali e umani si può risalire ricostruendo, gradino per gradino, una raffinazione progressiva del mentale come qualità. In questo quadro è il linguaggio ad avere un ruolo creatore - 'generativo' si potrebbe forse dire - differente rispetto a quanto è a disposizione degli animali. Il linguaggio ha la capacità di far comparire eventi e significazioni sempre nuove. Inoltre, tramite la creazione e l'interpretazione continua di segni dà nuova forma all'ambiente all'interno del quale viene usato: per usare un'espressione del filosofo Andy Clark (1998), l'uso del linguaggio ridisegna lo spazio computazionale delle opportunità di trasformazione che il mondo intorno ai soggetti offre. Un mondo che è però popolato di altri agenti-parlanti, coi quali siamo connessi quotidianamente: di questo bisogna pur trovare il modo di rendere conto in maniera strutturale. Fusaroli, Gangopadhyay e Tylén (2014) hanno parlato di una mente estesa dialogicamente, raccogliendo l'enfasi clarkiana sul ruolo del linguaggio come potenziatore cognitivo, ma provando a rendere più inclusiva quella proposta, che aveva il difetto di trascurare il ruolo del linguaggio come strumento per «l'attività sociale»: 
l'attività linguistica è un mezzo attraverso cui gli individui finiscono per apprendere e manipolare congiuntamente l'informazione al fine di creare sinergie informative e comportamentali a livello interazionale, che potenzialmente estendono quelle che sarebbero le abilità cognitive degli individui coinvolti da soli. Pertanto, il linguaggio inteso come un'abilità intersoggettiva (skilful intersubjective activity) va a costituire de facto delle menti estese dialogicamente. (Fusaroli, Gangopadhyay, Tylén 2014, 32; trad. dell'Autore)

L'idea alla base di questa controproposta è che il linguaggio non vada solamente inteso come una risorsa esterna per la cognizione individuale sempre intesa cerebro-centricamente, bensì come una «modalità di cognizione sociale nuova e senza precedenti dal punto di vista dell'evoluzione» (Fusaroli, Gangopadhyay, Tylén 2014, 32).

Tornando alle differenze col mondo animale, Enfield chiama in causa la nozione di 'cognizione sociale': questo concetto si riferisce a qualcosa di più complesso della sola spinta a interagire socialmente che è largamente condivisa da molte altre specie animali, che pure sono prive del linguaggio (Penn, Holyoak, Povinelli 2008). Il set di capacità cognitive che contraddistingue fortemente Homo sapiens cross-culturalmente include infatti

fiducia, cooperazione e tendenze altruistiche, capacità morali, intenzioni e azioni condivise, sensibilità alle regole locali, abilità di alto livello di modellare e tener conto delle credenze e conoscenze altrui. (Enfield 2013, 159; trad. dell'Autore)

Queste ultime sono le fondamenta della socialità umana che, secondo Enfield, sta al cuore del linguaggio. Questa è definita come l'insieme delle nostre «capacità cognitive orientate socialmente», tra cui il riconoscimento degli stati mentali altrui; la consapevolezza di ciò che gli altri vedono e sentono, di ciò che sanno o non sanno e della conoscenza condivisa; la capacità di attribuire stati intenzionali e finalità agli altri, come anche la capacità di considerare le attribuzioni altrui su noi stessi; le nostre «spinte micro-politiche» e la capacità di monitorare le relazioni umane all'interno di gruppi numerosi (Enfield 2010, 6; trad. dell'Autore). Se sembra difficile negare che tutti questi fattori siano rilevanti per una definizione della nostra vita cognitiva, linguistica e sociale, d'altra parte non si può neppure biasimare del tutto la ricerca che ha preferito soprassedere alla «gigantesca ontologia diffusa» dell'ambiente sociale umano (Enfield 2010, 6; trad. dell'Autore), frutto di sforzi collaborativi lunghi molte generazioni. Il nodo teorico si configura quindi come metodologico. Questo si è dato per buone ragioni, forse sintetizzabili in un'unica nozione metateorica: l'analogia della mente umana con una macchina computatrice ha reso trattabili molti problemi diffi- 
cilmente analizzabili a partire dalla loro complessità; ma allo stesso tempo questa analogia ha, almeno in parte, fatto il suo tempo e abbandonarla può essere proficuo.

\section{$4 \quad$ Paradigmi di ricerca}

Come fare per penetrare questo quadro assai complesso senza ricadere, ad esempio, nella fallacia retrospettiva che lo stesso Dewey sanzionava? Secondo Enfield e Sidnell (Sidnell, Enfield 2012; Enfield, Sidnell 2015), un modo - tra gli altri - utile per recuperare questo ritardo nello studio del linguaggio come strumento per l'interazione sociale è l'analisi della conversazione (AC), definibile come un campo a cavallo fra la sociolinguistica e la pragmatica linguistica, capace di mostrare quanto le strutture dell'interazione conversazionale siano assolutamente centrali all'idea che il linguaggio sia uno strumento per l'azione sociale. L'AC parte dal presupposto che la conversazione, intesa come attività spontanea che ha luogo quotidianamente in maniera naturale (e non programmata come potrebbe essere in setting sperimentali di laboratorio), abbia delle norme che ne regolano il flusso e che stanno alla base delle forme di interazione sociale umana. ${ }^{2}$ Metodologicamente, si fonda su dettagliate trascrizioni di interazione parlata free-flowing (Sidnell, Stivers 2013; Enfield 2017). Il vantaggio di questo tipo di approccio è che unisce aspetti quantitativi, da un lato, alla 'naturalità' del contesto di raccolta dei dati grezzi, a differenza di molte ricerche in campo cognitivo, e, dall'altro, a fenomeni complessi come l'interazione umana tradizionalmente oggetto di studio di scienze che utilizzano metodi qualitativi. ${ }^{3}$

Il continuismo deweyano sembra essere consonante a questo approccio: da questo punto di vista, non ha senso separare l'aspetto mentale da quello culturale di un'azione quotidiana come fare una telefonata (Enfield 2010,6) in quanto inestricabilmente intrecciati: l'azione sociale è sì definita dal fatto di essere contemporaneamente svolta da due menti individualmente, ma anche dal fatto di essere stata ereditata culturalmente in quanto prodotto di molte altre menti cronologicamente anteriori a quella presa in considerazione. La proposta è quella di indagare la cruciale connessione tra la «cognizione individuale» e la «cultura collettiva» tramite l'interazione sociale che le collega. Quel che unisce i tre elementi è che il linguaggio può

2 In sintesi, l'AC ha trovato che gli scambi conversazionali spontanei sono regolati da un set di norme universali, che pure presentano un range di variazione locale a livello crosslinguistico (Enfield 2017).

3 Alcuni, come Zinken (2016), sono arrivati a collegare strutture linguistiche di interazione analizzate a livello pragmatico e gestuale a concetti etici astratti come la responsabilità morale, studiando il caso delle richieste di cooperazione in contesti quotidiani. 
essere studiato a tutti questi livelli: al livello della mente, il linguaggio gioca un ruolo nelle rappresentazioni psicologiche e nei meccanismi di produzione e comprensione del discorso; culturalmente, il linguaggio è un sistema pubblico fondato su un processo di sedimentazione storica che supera ciascuna sua singola incarnazione; infine, è possibile analizzare il linguaggio

nella pratica attimo dopo attimo delle relazioni sociali, nelle quali osserviamo il linguaggio allo stato brado (in the wild), lo stesso in cui lo impariamo sia da bambini, sia da adulti e in cui i processi psicologici della produzione e della comprensione linguistica si incontrano e vengono esercitati. (Enfield 2010, 7; trad. dell'Autore)

Nessuno di questi tre livelli è di per sé privilegiato, ma è un dato di fatto che la ricerca spesso si sia concentrata su uno solo di questi. Il vantaggio di considerare il terzo livello si ottiene nel rendersi conto che l'uso del linguaggio, più che alla mera trasmissione di informazione, è rivolto all'azione: in particolare, all'azione volta a cambiare il mondo sociale all'interno del quale viviamo.

Nonostante l'approccio di Enfield sembri raggiungere un buon punto di equilibrio tra rigore metodologico e il pensarsi come primo mattone verso un orizzonte però ancora lontano come quello della creazione di una «tipologia dell'uso linguistico» (Enfield 2010, 18; trad. dell'Autore), è insito alla sua proposta un pericolo: più si tende all'olismo, più questo soddisfa il desiderio anti-riduzionistico comune a molti, ma allo stesso tempo più si corre il rischio di allontanarsi da una concretezza dell'esperienza descrivibile in termini precisi. In altre parole, il rischio di sconfinare in una vaghezza che si riveli in fondo vacua è più che concreto. Per ora, la posizione di ispirazione deweyana delineata finora non sembra cadere né nella miopia del riduzionismo né nella vacuità dell'olismo, grazie alla ricerca di un naturalismo né ingenuo, né scientista. La mente non è un mero software separato dal corpo che viaggia su binari quasi paralleli a quelli dell'esperienza sensibile, da un lato, e dai condizionamenti ecologicoculturali dall'altro. La mente è invece un insieme emergente e complesso di funzioni ben radicato nell'esperienza situata dei soggetti, che sono soggetti parlanti-agenti-computatori inseriti in un ambiente popolato da loro simili a cui sono connessi sin dalla nascita. Le ricerche di oggi mostrano che questa idea si sta rivelando molto feconda come perno per l'integrazione di diversi approcci disciplinari. 


\section{Bibliografia}

Arponen, V.P.J. (2013). «The extent of cognitivism». History of the Human Sciences, 26, 3-21.

Asoulin, Eran (2016). «Language as an Instrument of Thought». Glossa: A Journal of General Linguistics, 1(1), 46. DOI http://doi.org/10.5334/gjgl.34.

Björk, Ingrid (2008). Relativizing Linguistic Relativity: Investigating Underlying Assumptions about Language in the Neo-Whorfian Literature. Uppsala: Uppsala Universitet. Studia Linguistica Upsaliensia 6.

Boden, Margaret (2006). Mind as Machine: A History of Cognitive Science. Oxford: Oxford University Press.

Borghi, Anna M. et al. (2018). «Abstract Concepts, Language and Sociality: from Acquisition to Inner Speech». Philosophical Transactions of the Royal Society B, 373, n. 1752. DOI https://doi.org/10.1098/rstb.2017.0134.

Clark, Andy (1998). «Magic Words: How Language Augments Human Computation». Carruthers, Peter; Boucher, Jill (eds), Language and Thought: Interdisciplinary Themes. Cambridge: Cambridge University Press, 162-83.

Dewey, John (1991). Logic. The Theory of Inquiry. Later Works (12). Carbondale; Edwardsville: Southern Illinois University Press.

Diodato, Filomena (2019). «The Neo-humboldtian Lexical Field Theory. Origin, Reception and Perspectives». Paradigmi, 37(2), 259-74.

Dove, Guy (2018). "Language as a Disruptive Technology: Abstract Concepts, Embodiment and the Flexible Mind». Philosophical Transactions of the Royal Society B, 1752(373), 1-9. DOI https://doi.org/10.1098/ rstb.2017.0135.

Enfield, Nick J. (2010). Human Sociality at the Heart of Language. Nijmegen: Radboud University Nijmegen.

Enfield, Nick J. (2013). «Language, Culture, and Mind: Trends and Standards in the Latest Pendulum Swing». Journal of the Royal Anthropological Institute, 9(1), 155-69.

Enfield, Nick J. (2017). How We Talk. The Inner Works of Conversation. New York: Basic Books.

Enfield Nick J., Sidnell Jack (2015). «Language Structure and Social Agency: Confirming Polar Questions in Conversation». Linguistics Vanguard, 1(1), 131-43.

Fusaroli, Riccardo; Gangopadhyay, Nivedita; Tylén, Kristian (2014). «The Dialogically Extended Mind: Language as Skilful Intersubjective Engagement». Cognitive Systems Research, 29-30, 31-9.

Gardner, Howard (1985). The Mind's New Science: A History of the Cognitive Revolution. New York: Basic Books.

Lupyan, Gary (2015). «The Centrality of Language in Human Cognition». Language Learning, 66(3), 516-53.

Penn, Derek; Holyoak, Keith; Povinelli, Daniel (2008). «Darwin's Mistake: Explaining the Discontinuity Between Human and Nonhuman Minds». Behavioral and Brain Sciences, 31(2), 109-30.

Pennisi, Antonino; Falzone Alessandra (2015). «Parlanti impossibili, plausibili, reali. Prospettive biolinguistiche in filosofia del linguaggio». Rivista Italiana di Filosofia del Linguaggio, 160-72.

Sidnell, Jack; Enfield, Nick J. (2012). «Language Diversity and Social Action: A Third Locus of Linguistic Relativity». Current Anthropology, 53(3), 302-33.

Sidnell, Jack; Stivers, Tanya (eds) (2013). The Handbook of Conversation Analysis. Chichester (UK): Wiley-Blackwell. 
Batisti

Il linguaggio come collante tra menti individuali e socialità umana

Steiner, Pierre (2017). «Pragmatism in Cognitive Science: from the Pragmatic Turn to Deweyan Adverbialism». Pragmatism Today, 8(1), 9-27.

Vygotsky, Lev S. (1978). Mind in Society: the Development of Higher Psychological Processes. Cambridge (MA): Harvard University Press.

Zinken, Jörg (2016). Requesting Responsibility. The Morality of Grammar in Polish and English Family Interaction. New York: Oxford University Press. 
'Naturalismo' è una categoria che designa posizioni filosofiche tra loro diversificate, accomunate dal comune riferimento alla natura come oggetto primario dell'indagine filosofica. La riflessione filosofica della seconda metà del Novecento, in particolare di ambito analitico, si è orientata verso una progressiva identificazione del naturalismo con il solo naturalismo scientifico. II presente volume raccoglie gli atti di una giornata di studi dottorale che ha riunito dottorandi e professori dell'Università Ca' Foscari di Venezia e dell'Université Paris 1 Panthéon-Sorbonne con l'obiettivo di mostrare come un approccio naturalista e le nozioni in esso implicate costituiscano fruttuose categorie di interpretazione della realtà al di fuori del paradigma scientista.

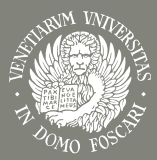

Università Ca'Foscari Venezia 